\title{
THE END(S) OF ANALOGUE: ACCESS TO CBC/RADIO-CANADA TELEVISION PROGRAMMING IN AN ERA OF DIGITAL DELIVERY
}

by

Steven James May

Master of Arts, Ryerson University, Toronto, Ontario, Canada, 2008

Bachelor of Applied Arts (Honours), Ryerson University, Toronto, Ontario, Canada, 1999 Bachelor of Administrative Studies (Honours), Trent University, Peterborough, Ontario, Canada, 1997

A dissertation presented to Ryerson University and York University in partial fulfillment of the requirements for the degree of Doctor of Philosophy in the Program of Communication and Culture

Toronto, Ontario, Canada, 2017

(C) Steven James May, 2017 


\section{AUTHOR'S DECLARATION FOR ELECTRONIC SUBMISSION OF A DISSERTATION}

I hereby declare that I am the sole author of this dissertation. This is a true copy of the dissertation, including any required final revisions, as accepted by my examiners.

I authorize Ryerson University to lend this dissertation to other institutions or individuals for the purpose of scholarly research.

I further authorize Ryerson University to reproduce this dissertation by photocopying or by other means, in total or in part, at the request of other institutions or individuals for the purpose of scholarly research.

I understand that my dissertation may be made electronically available to the public. 


\section{ABSTRACT}

The End(s) of Analogue: Access to CBC/Radio-Canada Television Programming in an Era of Digital Delivery

Steven James May

Doctor of Philosophy in the Program of Communication and Culture

Ryerson University and York University, 2017

This dissertation studies the political economy of public television access in Canada as manifest in the country’s 2011 digital television/télévision numérique transition. Specifically, this dissertation scrutinizes the provision of access to television programming offered by Canada's national public broadcaster, the Canadian Broadcasting Corporation/Société RadioCanada (CBC/Radio-Canada), and how CBC/Radio-Canada's response to Canada's 2011 digital television transition corresponds with its mandate under the Broadcasting Act to ensure that its programming is "made available throughout Canada by the most appropriate and efficient means and as resources become available for the purpose" (Canada, 1991). Drawing from research interviews conducted with disconnected analogue over-the-air (OTA) CBC/Radio-Canada television-viewing households and members of CBC/Radio-Canada Management involved with the public broadcaster's response to Canada's digital television transition deadline, this dissertation finds competing accounts of how public television delivery is linked to the provision of access to the public broadcaster's television programming in the digital age. While interviewed members of CBC/Radio-Canada Management describe an inefficient analogue OTA public television delivery system that would be best superseded by more efficient modes of digital delivery, OTA CBC/Radio-Canada television-viewing households describe an analogue OTA CBC/Radio-Canada television service that had been providing access to CBC/RadioCanada television programming and describe a digital disconnect following CBC/Radio- 
Canada's digital television transition. This dissertation questions the post-analogue public television delivery operations of $\mathrm{CBC} /$ Radio-Canada; mainly that public television delivery cost savings achieved as a result of $\mathrm{CBC} /$ Radio-Canada's response to Canada's digital television transition deadline have resulted in gaps in access to $\mathrm{CBC} /$ Radio-Canada television programming by some Canadian households as articulated through this dissertation's Public Media Access Puzzle Sieve (Public M.A.P.S.) model. The Public M.A.P.S. model offers a means by which to both anticipate and assess levels of access to public media based on the model's elements of access related to cost, availability, functionality, opportunities for à la carte service, and access to locally relevant feed(s). In the case of $\mathrm{CBC} /$ Radio-Canada, gaps in household access to the public broadcaster's digital television programming as identified by the Public M.A.P.S. model help to underscore deficiencies in Canada's post-analogue television system, the information communication technology (ICT) sector, and domestic spectrum management practices. 


\section{ACKNOWLEDGEMENTS}

I would like to acknowledge the following people.

Douglas Barrett

John Bishop

(Members of) CBC Management interviewed for this dissertation

Canadian Media Research Consortium

Amanda Dawn Christie

Lynn Cunningham

Zachary Devereaux

Cathy Edwards

Greg Elmer

Brian Fauteux

Jordan Hale

Rob Heydari

The Jeffrey Family

Diane Jenner

Daniel Joseph

Infoscape Research Lab: Centre for the Study of Social Media

Jon Keeble

Benjamin Klass

Avner Levin

Anne MacLennan

Fenwick McKelvey

Jo Ann Mackie

Jeffrey May (Dad)

Marilyn May (Mom)

Catherine Middleton

Dan Misener

Paul Moore

Ian Morrison, Friends of Canadian Broadcasting

Michael Murphy

Greg O’Brien

Andy Opel

OTA CBC/Radio-Canada television-viewing households interviewed for this dissertation

Daniel J. Paré

Felan Parker

Isabel Pedersen

Ted \& Loretta Rogers

Peter Ryan

Kirstine Stewart

Gregory Taylor

Alexa Tullett

Ana Viseu

Miles Weafer

Karen Wirsig 


\section{DEDICATION}

This dissertation is dedicated to the following people.

Howard Alton, P.Eng. (1923-2015)

Nancy Jean MacDougall, B.A. (1966-2010)

Ruth Patterson (Moffat) May (1918-2010) 


\section{Table of Contents}

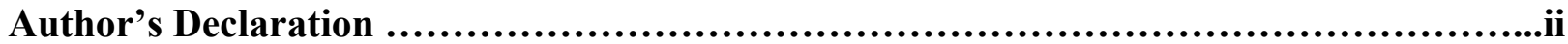

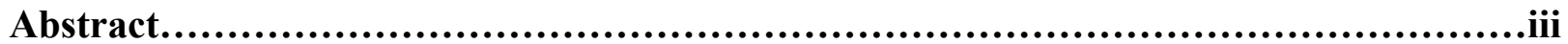

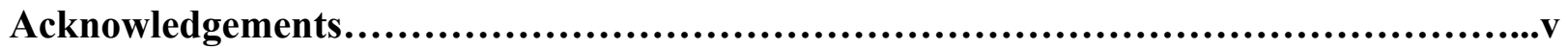

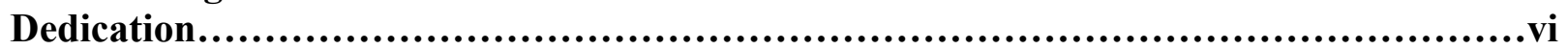

Table of Contents ..............................................................................vii

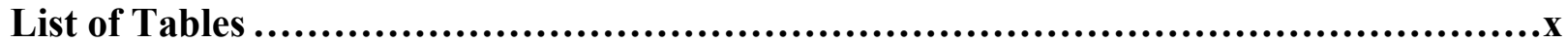

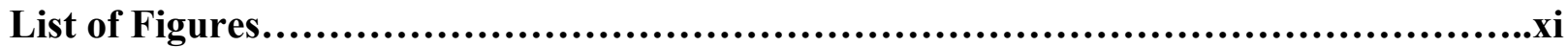

List of Illustrations.......................................................................... xii

List of Appendices..........................................................................xiii

Chapter 1: Introduction ................................................................................................................. 1

The End(s) of Analogue ..................................................................................................................... 1

Public Service Broadcasting (PSB) to Public Service Media (PSM).................................................... 12

Chapter 2: Access to CBC/Radio-Canada programming, 1936 to 2016 ..................................... 19

The dawn of CBC/Radio-Canada..................................................................................................... 20

CBC/Radio-Canada's expansion into television broadcasting ............................................................... 23

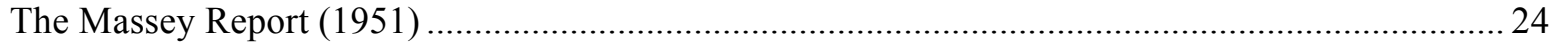

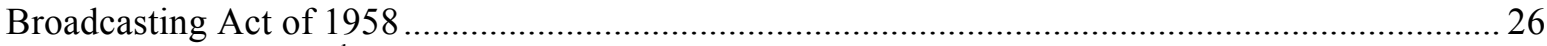

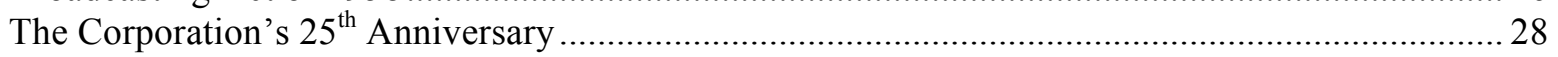

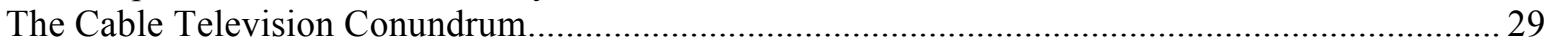

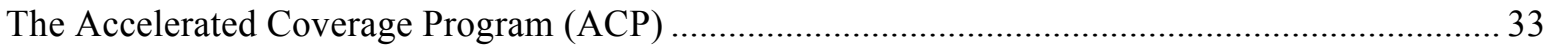

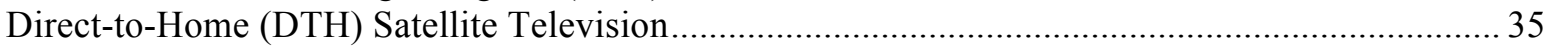

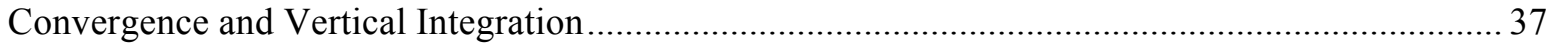

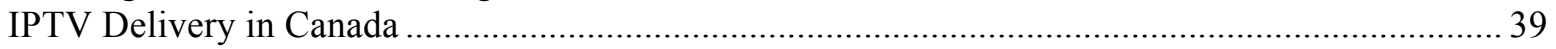

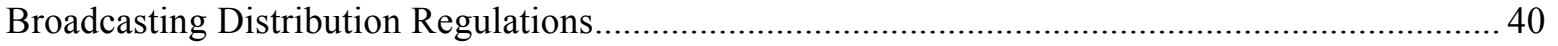

Internet and Wireless Mobile Television Delivery ……………………………………………… 42

CBC/Radio-Canada Analogue OTA Television Redux ………………………………………….... 47

Chapter 3: Canada's 2011 Digital Television Transition .............................................................5 50

Role of Shaw's Local Television Satellite Solution (LTSS) ……................................................ 55

CBC/Radio-Canada's response to Canada's 2011 Digital Television Transition deadline ...........57

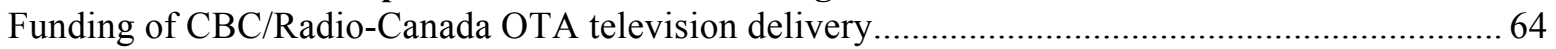

Global perspectives on post-analogue public television broadcasting .................................................. 69

Chapter 4: Literature Review.............................................................................................................. 81

Provision of Access to Public Service Broadcasting ............................................................................ 84

Public Broadcasting as a Public Good/Service ………………....................................................... 87

The Task of Serving the Imagined Community of Canada by way of public spectrum ..................... 89

The Public Interest vs. Consumer Choice ................................................................................ 92

Disintermediation: Threat or Opportunity for Public Service Media? ……………………………...... 94

User agency and Public Service Media (PSM) …………………………................................. 98

Efficiency and Public Broadcasting in the Digital Age …………………………………………........ 100

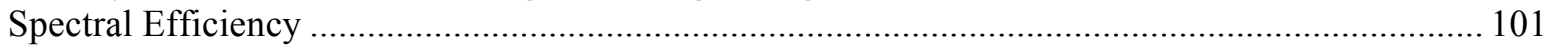

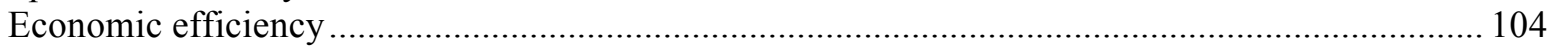

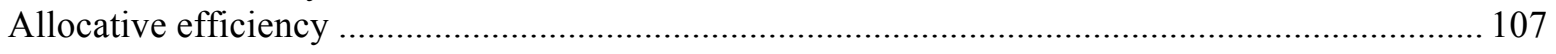

Chapter 5: Methodology.............................................................................................................. 110 


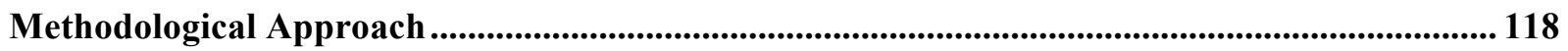

Chapter 6: Findings ......................................................................................................... 133

A) Canadian OTA CBC/Radio-Canada television-viewing household interviews ............. 134

Access to CBC/Radio-Canada television via analogue OTA broadcasting ...................................... 134

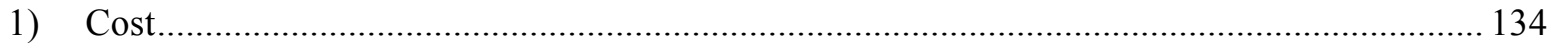

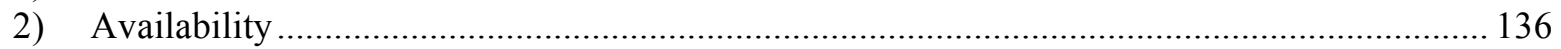

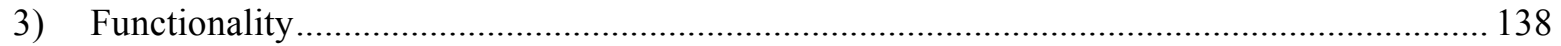

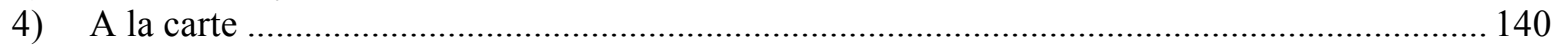

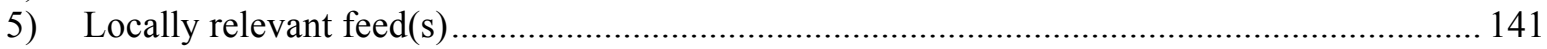

Access to CBC/Radio-Canada television post-analogue OTA broadcasting............................... 142

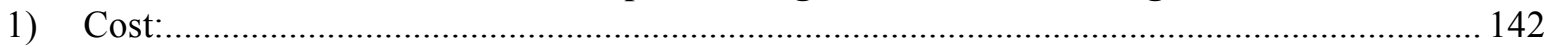

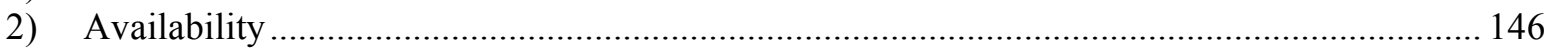

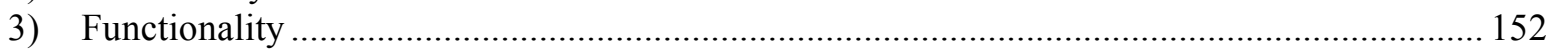

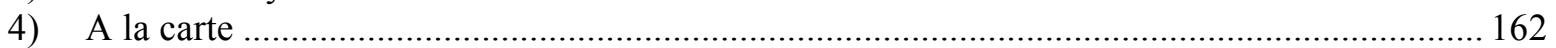

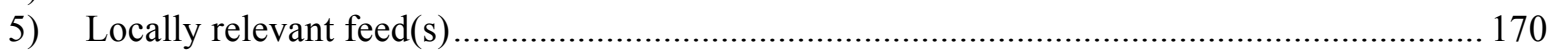

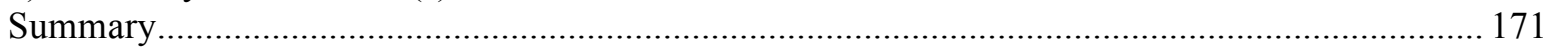

B) CBC/Radio-Canada Management interviews ............................................................... 174

Access to CBC/Radio-Canada television via analogue OTA broadcasting ..................................... 174

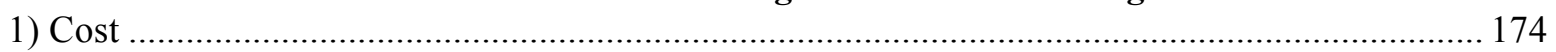

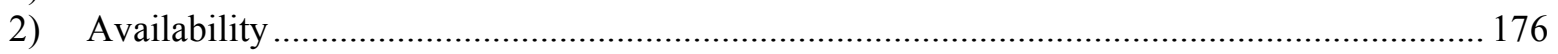

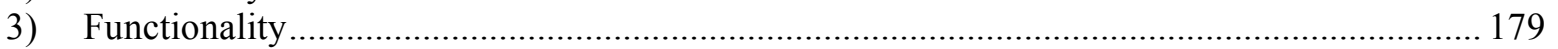

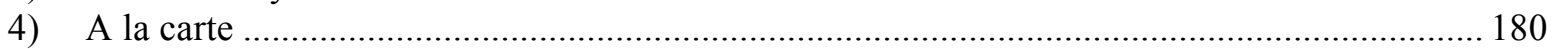

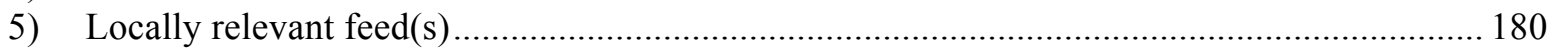

Access to CBC/Radio-Canada television post-analogue OTA broadcasting.................................... 182

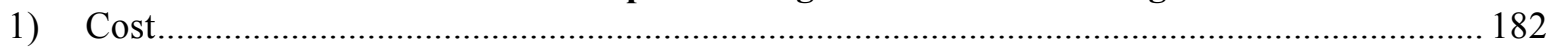

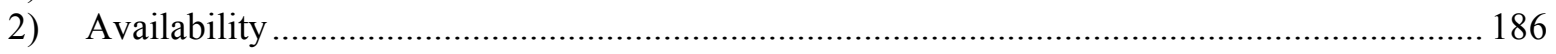

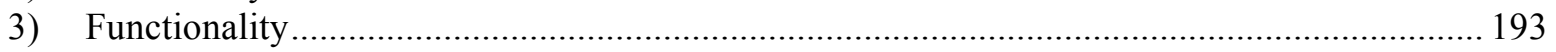

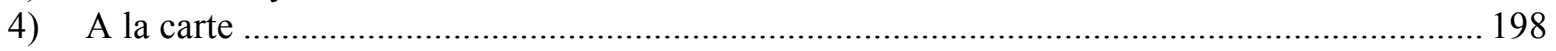

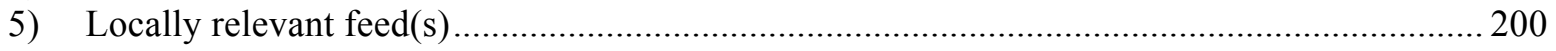

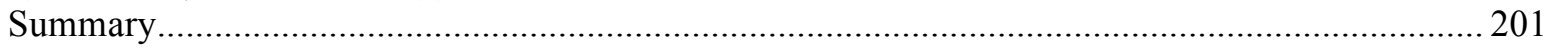

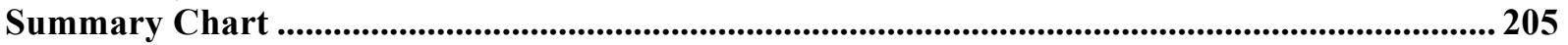

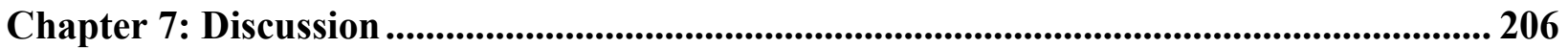

Public Media Access Puzzle Sieve (Public M.A.P.S.) model ........................................................ 206

i) How do notions of digital technology and digital television delivery efficiency relate to citizen access to CBC/Radio-Canada's television programming?............................................................213

ii) What role did CBC/Radio-Canada's analogue over-the-air (OTA) television transmitters/retransmitters play in the provision of citizen access to CBC/Radio-Canada television programming prior to their shutdown?.

iii) What role does CBC/Radio-Canada's current network of digital over-the-air (OTA) television transmitters play in the provision of citizen access to $\mathrm{CBC} / \mathrm{Radio}$-Canada television programming by Canadian television-viewing households?

iv) Did Canada's reallocation of the publicly owned $700 \mathrm{MHz}$ electromagnetic radio spectrum associated with the country's 2011 digital television transition serve to enhance citizen access to

CBC/Radio-Canada television programming? ........................................................................................ 228

Forced household migration to paid and/or usage based access to CBC/Radio-Canada television. 238

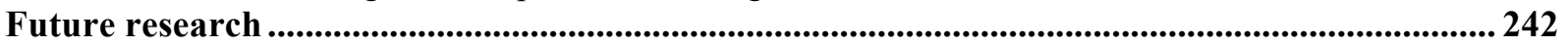

Chapter 8: Conclusion ....................................................................................................... 244

Summary of key findings ................................................................................................................................. 247 


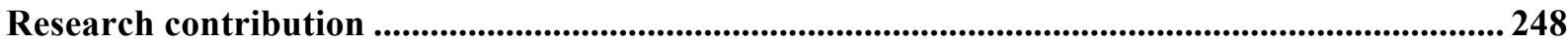

CBC/Radio-Canada's Digital Television Transmitters: Burden or Asset? ................................... 250

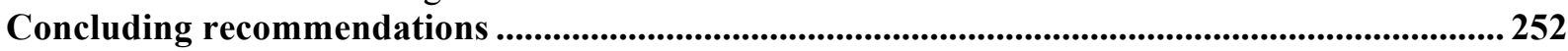

1) Unencrypt CBC/Radio-Canada satellite television downlinks ........................................ 253

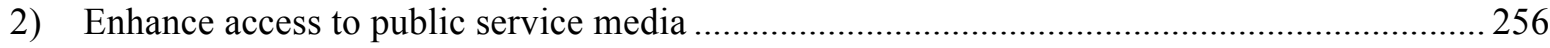

3) Embrace the CRTC's 2015 OTA Television Broadcasting Revelation .................................. 264

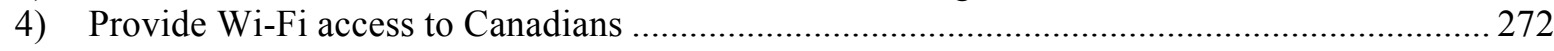

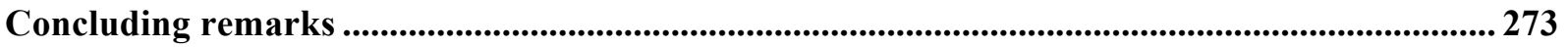

Appendix 1: OTA CBC/Radio-Canada television-viewing household research participants 275

Appendix 2a: Interview questions ............................................................................................. 278

Appendix 2b: Interview questions ................................................................................................ 279

Appendix 2c: Interview questions ............................................................................................. 280

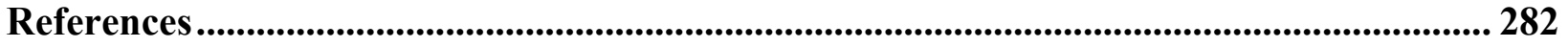




\section{LIST OF TABLES}

Table 1: CBC/Radio-Canada digital over-the-air (OTA) television transmitters as of July $31,2012 \ldots . .61$

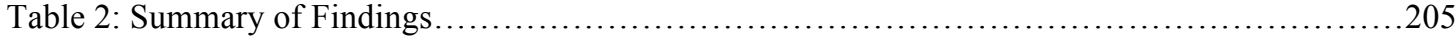




\section{List of Figures}

Figure 1. Brevini's Components of Universality Model.........................130

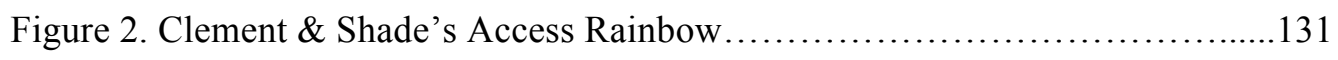

Figure 3. Public Media Access Puzzle Sieve (Public M.A.P.S.) model...............208 


\section{List of Illustrations}

(Cartographer: Jeff Allen)

Illustration 1. CBC/Radio-Canada analogue over-the-air (OTA) television transmitters as of August 2011...63

Illustration 2. CBC/Radio-Canada digital over-the-air (OTA) television transmitters as of August 2012......63 


\section{LIST OF APPENDICES}

Appendix 1: OTA CBC/Radio-Canada television-viewing household research participants.............275

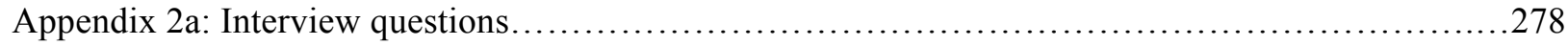

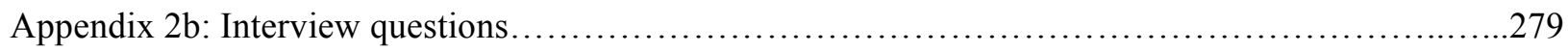

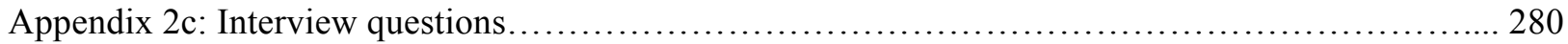




\section{Chapter 1: Introduction}

\section{The End(s) of Analogue}

Analogue over-the-air television technology has been in decline for years. It is now virtually obsolete. Very few Canadians still use "rabbit-ear" [sic] to watch TV. CBC/Radio-Canada has been aware of this decline for some time, but had originally planned to continue broadcasting in analogue beyond the current year.

However, the acceleration of the shut-down [sic] is one of the measures announced by the Corporation to deal with the recent reduction in its parliamentary appropriation. The move will save $\$ 10$ million a year, money that the Corporation will be able to put into programming.

Continuing to operate 607 transmitters to reach just 1.7 percent of the population would not be an efficient use of our resources at the best of times, and it is simply not viable given the current circumstances.

CBC/Radio-Canada apologizes for any inconvenience this change may cause.

(CBC/Radio-Canada, 2012a)

This statement posted to the website of Canada's national radio and television public broadcaster, the Canadian Broadcasting Corporation/Société Radio-Canada (CBC/RadioCanada), outlines the reasoning behind the public broadcaster's decision to shut down its analogue over-the-air (OTA) television service on July 31, 2012. It accurately notes that the analogue technology $\mathrm{CBC} /$ Radio-Canada had been using to broadcast its television programming to Canadian households OTA by way of Hertzian waves had "been in decline for years" and that "few Canadians" still received their television via an OTA antenna (although the uncited 1.7 percent statistic is rather dubious, particularly since it had been previously referenced in relation to $\mathrm{CBC} /$ Radio-Canada's earlier network of 620 (CBC/Radio-Canada, 2012i) analogue OTA television transmitters). Despite the certainly low number of analogue OTA television viewers in Canada, CBC/Radio-Canada had nonetheless continued to operate its "virtually obsolete" 
analogue OTA television service for more than a decade into the twenty-first century at a reported cost of $\$ 10$ million per year (CBC/Radio-Canada, 2012a). It was not until Canada's 2011 digital television/télévision numérique transition deadline that CBC/Radio-Canada opted to execute a plan that would see its overall OTA television delivery infrastructure drastically reduced.

Canada's broadcasting and telecommunications regulator, the Canadian Radio-television and Telecommunications Commission (CRTC), noted at the time that "[o]ne of the main reasons for switching to digital television is the need for more spectrum, commonly referred to as frequencies or airwaves" and that "[d]igital technology also provides better picture and sound" (CRTC, 2016f). In contrast to the rationale for the changes to Canada's analogue television broadcast system as articulated by the CRTC, CBC/Radio-Canada stressed that the primary rationale for the shutdown of its analogue OTA television transmitters was that it was a cost saving opportunity that would allow the Crown corporation to make "efficient use" of its resources ${ }^{1}$. As such, CBC/Radio-Canada's response to Canada's digital television transition involved turning off and removing its (by then) remaining network of 607 analogue OTA television transmitters/retransmitters dispersed across the country and replacing them with only 27 digital OTA television transmitters located within 20 select Canadian television markets. As to why CBC/Radio-Canada did not install additional digital OTA television transmitters, it noted,

Ultimately our industry should be aiming to have all Canadian homes connected to the digital economy through high-speed Internet, broadband satellite or cable, where the future of our industry clearly lies. (CBC/Radio-Canada, 2012f).

\footnotetext{
${ }^{1}$ The reason Canada's digital television transition presented a cost saving opportunity for the public broadcaster was due to the fact that $\mathrm{CBC}$ /Radio-Canada replaced fewer than five percent of its analogue OTA television transmitters/retransmitters with digital OTA television transmitters.
} 
CBC/Radio-Canada's 2012 operational response to Canada's 2011 digital television transition deadline is the focus of this dissertation. This first chapter outlines CBC/RadioCanada's response to Canada's 2011 national digital television transition deadline and sets out the central research question and four sub-research questions posed by this dissertation. This chapter also outlines CBC/Radio-Canada's shift from public service broadcaster (PSB) to public service media (PSM) and introduces the Public Service Media Access Puzzle Sieve (Public M.A.P.S.) model developed through this dissertation's analysis of research interviews conducted with 99 analogue OTA CBC/Radio-Canada television-viewing Canadian households that lost OTA access to one or more CBC/Radio-Canada television stations between 2011 and 2012 and five members of CBC/Radio-Canada Management involved in the public broadcaster's operational response to Canada's 2011 digital television transition.

CBC/Radio-Canada's custom response to Canada's digital television transition offers an opportunity to examine the political economy of citizen access to public media in the digital age. Gazing back to the future of Canadian television delivery, this dissertation's focus on post-analogue access to CBC/Radio-Canada television programming calls for discussion of twenty-first century access to digital communications to recognize barriers to digital over-the-air (OTA) television. In instances where over-the-air television (OTA) service (alternatively known as conventional television, free-to-air television, or terrestrial television) to a household is degraded or cut-off as a result of a transition to digital OTA, the quality of household television access provided by other modes of television delivery such as cable, satellite, and the Internet (often touted by subscription television providers and government regulators alike as being enhanced and ubiquitous modes of television access) is brought to the forefront and is put to the test. As such, Canadian CBC/Radio-Canada 
television-viewing households that lost OTA access to CBC/Radio-Canada television ${ }^{2}$

programming at some point between 2011 and 2012 as a result of the public broadcaster's response to Canada's digital television transition provide insight into barriers to television access in the digital age, particularly citizen access to television programming offered by public broadcasters.

The importance of the provision of access to public television programming in a digital environment is linked to the status of cultural citizenship as articulated by media scholars such as Toby Miller (2013). Miller (2013) identifies three "zones" of citizenship: "the political (the right to reside and vote); the economic (the right to work and prosper); and the cultural (the right to know and speak)" (p. 34). In his discussion of the relationship between media policy and access to television programming (specifically to sports programming), Miller (2013) argues that while the zone of political citizenship "has been overdetermined by economic citizenship" beginning in the 1970s and embodied in the neoliberal regulatory policies of past UK Prime Minister Margaret Thatcher, the zone of cultural citizenship “offers a riposte to this domination of right-wing economism” (p. 34). Miller (2013) argues that the notion of cultural citizenship "can be used to argue for democratic interventions in and responses to changes" in the media (p. 35). CBC/RadioCanada's response to Canada's 2011 digital television transition can therefore be seen as an

\footnotetext{
2 The radio and television services of CBC/Radio-Canada, also referred to as "the Corporation", are divided into English Services and French Services. As of September 2016, CBC/Radio-Canada's English television service was named CBC Television and its French television service was named ICI Radio-Canada Télé. Since the name of the French television service at the time of Canada's digital television transition was Télévision de Radio-Canada, this dissertation uses that name when discussing the French television service. In addition, since CBC/Radio-Canada's over-the-air (OTA), official referred to as "conventional", television licence is a singular licence, this dissertation refers to both television services collectively as CBC/Radio-Canada television, other than in cases where the English and French television services differ in terms of provision of access.
} 
example of a change to the Canadian media landscape that is linked to the post-analogue status of cultural citizenship in the country.

This dissertation approaches CBC/Radio-Canada's reliance on cable, satellite, and IPTV providers (collectively referred to in Canada as Broadcasting Distribution Undertakings or BDUs), Internet Service Providers (ISPs), and mobile wireless (i.e.: cell phone) providers to deliver its television programming outside of markets where it has digital OTA television transmitters as an opportunity to assess $\mathrm{CBC} /$ Radio-Canada's ability to ensure unencumbered access to its television programming following the shutdown of its analogue OTA television service.

The central research question that this dissertation asks is whether CBC/RadioCanada's 2012 operational response to Canada's 2011 digital television transition has enhanced the universality of access to its television programming in the digital age. This dissertation's contribution to the political economy of communication (PEC) entails questioning the aims of Canada's regulated broadcast and telecommunications systems in the digital age with specific respect to the provision of post-analogue access to public service media (PSM) in the country. This dissertation's central research question is approached by way of answering the following four sub-research questions;

i) How do notions of digital technology and digital television delivery efficiency relate to citizen access to $\mathrm{CBC} /$ Radio-Canada's television programming?

ii) What role did CBC/Radio-Canada's analogue over-the-air (OTA) television transmitters/retransmitters play in the provision of citizen access to $\mathrm{CBC} /$ Radio-Canada television programming prior to their shutdown?

iii) What role does $\mathrm{CBC} /$ Radio-Canada's current network of digital over-the-air (OTA) television transmitters play in the provision of citizen access to 
$\mathrm{CBC} /$ Radio-Canada television programming by Canadian television-viewing households?

iv) Did Canada's reallocation of the publicly owned $700 \mathrm{MHz}$ electromagnetic radio spectrum associated with the country's 2011 digital television transition serve to enhance citizen access to $\mathrm{CBC} /$ Radio-Canada television programming?

This dissertation's focus on how CBC/Radio-Canada's response to Canada's 2011 digital television transition has impacted the delivery of its television programming to a decidedly minority group of OTA CBC/Radio-Canada television-viewing Canadian households is tied to the importance that Lisa Parks (2013a) places on the role that infrastructure continues to play in the provision of access to programming in the digital era,

It is worth thinking carefully about how our critical practices and methods are shaped and informed not only by our social subjectivities, technological literacies, and intellectual training, but also by the geophysical positions we are willing to engage with, occupy, or explore. How often do we move beyond what Mark Andrejevic (2009) calls the digital enclosure or what Nick Couldry (2003) calls the media centre? If we are willing to take seriously the fusion of the biological and the technological, it is important to consider not only how consumer electronics become human prostheses but also how automated facilities on the outskirts of cities that are dug deep into the dirt and surrounded by plants and wildlife - seemingly in the middle of nowhere - are integral to broadcasting in the digital age. (p. 303).

In addition to an interest in the role that infrastructure plays in the provision of access to $\mathrm{CBC} /$ Radio-Canada television programming in the digital age, this dissertation is also interested in the role that spectrum plays in the provision of such access. As Canada's first television broadcaster (and past regulator), $\mathrm{CBC} /$ Radio-Canada has used publicly owned spectrum to deliver its public television programming for more than 60 years. As noted by Industry Canada (since re-named Innovation, Science and Economic Development Canada, or ISED), 
The radio frequency spectrum is a natural resource managed for the benefit of all Canadians. Industry Canada endeavours to provide access to this resource with minimal administrative burden while ensuring the efficient use of the radio frequency spectrum. (Industry Canada, 2015b)

In terms of the links between spectrum management and citizenship, Graham Longford (2008) stresses that "while the radio spectrum is often taken for granted, its importance to our communication and cultural rights and freedoms can scarcely be overstated: i.e., spectrum matters" (p. 95). With ISED responsible for allocating which bands of spectrum are used for television delivery in Canada, including but not limited to the Very high frequency (VHF) and Ultra high frequency (UHF) bands allocated for OTA television broadcasting, the CRTC is responsible for managing Canada's broadcasting system in accordance with the Broadcasting Act. As noted by Marc Raboy (2010), "the Broadcasting Act can be seen as the cornerstone of Canadian communication rights with respect to media" (p. 104). Making specific reference to the use of spectrum (also referred to as radio frequencies) for radio and television broadcasting, the Act states,

[t]he Canadian broadcasting system, operating primarily in the English and French languages and comprising public, private and community elements, makes use of radio frequencies that are public property and provides, through its programming, a public service essential to the maintenance and enhancement of national identity and cultural sovereignty. (Canada, 1991, Section 3. (1) (b))

While the public, private, and community elements of Canada's broadcasting system are expected to collectively provide, in unison, a singular broadcast system to Canadians, Section 3. (1) (l) through $(n)$ of the Act specifies the following particular requirements for the radio and television services provided by CBC/Radio-Canada ("the Corporation") as a national public broadcaster - the sole broadcaster explicitly named in the Act; 
( $l$ ) the Canadian Broadcasting Corporation, as the national public broadcaster, should provide radio and television services incorporating a wide range of programming that informs, enlightens and entertains;

$(m)$ the programming provided by the Corporation should

(i) be predominantly and distinctively Canadian,

(ii) reflect Canada and its regions to national and regional audiences, while serving the special needs of those regions,

(iii) actively contribute to the flow and exchange of cultural expression,

(iv) be in English and in French, reflecting the different needs and circumstances of each official language community, including the particular needs and circumstances of English and French linguistic minorities,

(v) strive to be of equivalent quality in English and in French,

(vi) contribute to shared national consciousness and identity,

(vii) be made available throughout Canada by the most appropriate and efficient means and as resources become available for the purpose, and

(viii) reflect the multicultural and multiracial nature of Canada;

(n) where any conflict arises between the objectives of the Corporation set out in paragraphs $(l)$ and $(m)$ and the interests of any other broadcasting undertaking of the Canadian broadcasting system, it shall be resolved in the public interest, and where the public interest would be equally served by resolving the conflict in favour of either, it shall be resolved in favour of the objectives set out in paragraphs (l) and (m)

(Canada, 1991)

Within the lengthy passage of the Act quoted-above lies the expectation that the Corporation make its radio and television programming "available throughout Canada by the most appropriate and efficient means and as resources become available for the purpose" (Canada, 1991, 3. (1) (m) (vii)). Section 3 of the Act also notes that if "any conflict arises" between the Corporation and the rest of the broadcasting system, such a conflict is to be resolved in the public interest. In the case of a public interest tie, a resolution is to be made in the interest 
of the objectives of the Corporation. In other words, the objectives of $\mathrm{CBC} /$ Radio-Canada are supreme under the Act.

The "be made available throughout Canada" subsection of CBC/Radio-Canada's radio and television services as specified in the Broadcasting Act embodies the universality of access component of the public broadcaster's operations. Universality of access has historically been a core aim for public broadcasters providing service to citizens around the world dating back to the earliest days of public radio broadcasting in the 1920s by the British Broadcasting Company (BBC) in the United Kingdom. According to UNESCO, the public service broadcasting aim of "universality" requires that,

Public broadcasting must be accessible to every citizen throughout the country. This is a deeply egalitarian and democratic goal to the extent that it puts all citizens on the same footing, whatever their social status or income. It forces the public broadcaster to address the entire population and seek to be "used" by the largest possible number. (UNESCO, 2005, p. 15)

Initially, the Canadian Broadcasting Corporation relied upon analogue OTA television transmitters owned and operated by the public broadcaster to make its television programming accessible to Canadian citizens, commencing in 1952 by way of Hertzian waves broadcast through Canada's publicly owned electromagnetic radio spectrum. By 1953, the Corporation's ability to further disseminate its television programming was provided by way of analogue OTA transmitters owned and operated by affiliated private television broadcasters that were licensed to air programming sourced (for no fee) from the Corporation. The public broadcaster's ability to make its television programming available throughout Canada was further enhanced in the early-mid 1970s when the CRTC introduced regulation requiring Canadian cable television providers to distribute "all local television stations", "particular priorities for the Canadian 
Broadcasting Corporation ('the Corporation') and for provincial educational television stations" (Bird, 1988, p. 428). Subsequently revised regulations by the CRTC followed, including the Broadcasting Distribution Regulations introduced in 1997 which required all Terrestrial Broadcasting Undertakings other than direct-to-home (DTH) satellite providers to distribute as part of their basic packages "the programming services of all local television stations that are owned and operated by the Corporation" (Canada, 1997, p. 32). The Broadcasting Distribution Regulations also extended required distribution of $\mathrm{CBC} /$ Radio-Canada television stations to DTH satellite providers, although on a more regional basis than Terrestrial Broadcasting Undertakings.

While regulations related to the required distribution of $\mathrm{CBC} /$ Radio-Canada television stations in English and French by Canadian BDUs were not without flaws, particularly with respect to regulation pertaining to DTH satellite providers that, as $\mathrm{CBC} /$ Radio-Canada itself has pointed out, does not "guarantee citizens access to their local CBC or Radio-Canada station" (CBC/Radio-Canada, 2010), the combined use of analogue OTA television transmitters and BDU distribution regulations made great strides in the analogue television era towards providing flexible options for access to $\mathrm{CBC} /$ Radio-Canada television programming.

The case study of CBC/Radio-Canada's 2012 operational response to Canada's 2011 digital television transition deadline provided an opportunity to study "a contemporary phenomenon within its real-life context" (Yin, 1994, p. 13). Commencing in July 2012, this dissertation undertook qualitative, semi-structured, primary research interviews with a nonrandom, purposive sample of 99 analogue OTA CBC/Radio-Canada television viewing households and five members of $\mathrm{CBC} /$ Radio-Canada Management. Combined, these interviews provide an account of $\mathrm{CBC} /$ Radio-Canada Management's switch from analogue to digital OTA 
television delivery as it was underway and an account of the lived experiences of OTA Canadian television viewing households whose access to $\mathrm{CBC} /$ Radio-Canada television was disrupted following the public broadcaster's response to Canada's digital television transition.

This dissertation's original research contribution is the Public Media Access Puzzle Sieve (Public M.A.P.S.) model (see Figure 3). The model, developed through analysis of this dissertation's research findings, adds to the existing body of research related to citizen access to digital communications, such as Andrew Clement and Leslie Regan Shade's (2000) Access Rainbow model and Benedetta Brevini's (2013) Components of Universality model, by extending the discussion of the digital divide to include the challenge of the post-analogue provision of access to public television programming as embodied in the following five elements of the Public M.A.P.S. model with regards to barriers to public television programming access;
1) Cost
2) Availability
3) Functionality
4) A la carte service
5) Locally relevant feed(s)

This dissertation's findings reveal differing accounts of the post-analogue status of these five access elements in relation to the shutdown of $\mathrm{CBC} /$ Radio-Canada's analogue OTA television service and of how best to digitally deliver CBC/Radio-Canada television programming based on differing notions of television delivery appropriateness and efficiency. When imagining the means by which access to $\mathrm{CBC} /$ Radio-Canada television might be provided in a post-analogue media environment, this dissertation is chiefly concerned with to whom different modes of $\mathrm{CBC} /$ Radio-Canada television delivery are considered to be appropriate and 
efficient within a digital delivery environment, and whose resources are being expended to achieve public television access by Canadians.

\section{Public Service Broadcasting (PSB) to Public Service Media (PSM)}

Hubert Lacroix, President and CEO of CBC/Radio-Canada, described the digital media challenge facing the public broadcaster in CBC/Radio-Canada's 2014-2015 Annual Report as follows,

Constant, borderless digital connectivity is already changing the way we relate to the world and to each other. We can now reach tens of millions through a single Facebook post! To rise to its full potential, CBC/Radio-Canada needs to evolve not just to survive, but to thrive in the era beyond traditional broadcasting. (CBC/Radio-Canada, 2015a, p. 5)

The enthusiasm expressed by Lacroix regarding the reach of CBC/Radio-Canada's Facebook posts, including, for example, a 2015 CBC News video segment posted to the CBC News Facebook account featuring a Saskatoon man's custom beer pong table which had amassed close to 35 million views as of August 2015 (Lacroix, 2015, August 6), reflects the ongoing global transformation of public service broadcasters (PSB) to public service media (PSM). Apart from the hyperbolic suggestion that Canada has actually achieved "[c]onstant, borderless digital connectivity", along with the conundrum of Lacroix trumpeting use of the privately owned and operated American social media platform Facebook to deliver CBC/Radio-Canada content to Canadians (via unmentioned Canadian ISPs and mobile wireless operators), Lacroix nonetheless articulates that $\mathrm{CBC} /$ Radio-Canada now operates in an environment that is no longer limited to traditional one-way public service broadcasting. As noted by Brian Fauteux (2015), CBC/RadioCanada's most recent CRTC licence renewal in 2013 "positioned the corporation within a society that was now more dependent on digital technologies" (p. 22). 
Karol Jakubowicz (2010) defines PSM as "PSB 3.0" (with PSB 2.0 defined by Jakubowicz as post-1980s traditional public broadcasting within a multi-channel television universe), or alternatively, "PSB + all relevant platforms + Web 2.0" (p. 14). As detailed by Agnes Gulyás (2013), “[h]istorically, PSBs developed as national broadcasting institutions with a top-down style of media production and dissemination technologies, features which are increasingly outdated in a more open, many-to-many networked digital environment" (p. 139140). Gulyás (2013) notes that within a digital media environment "previous rationales for control over media creation are challenged as authority in media production is dispersed and shared" (p. 139).

For Petros Iosifidis (2010), PSM involves PSBs “widening their remit to be available in more delivery platforms for producing and distributing public service content. Cross-platform strategies help PSM retain audience share, reach new audiences and develop on-demand services, while enabling them to create a stronger partnership with civil society and serve an extended form of citizenship" (p. 1). Iosifidis (2010) also notes that this shift to PSM also presents PSBs with a number of challenges including "the legitimacy and performance of PSBs in a multimedia ecology characterised by convergence and fragmentation" and that this shift "has brought into question the very legitimacy of national communities, identities and ideologies" ( $p$. $1)$.

$\mathrm{CBC} /$ Radio-Canada's success at achieving the aims of its mandated radio and television broadcasting services hinges on its ability in the digital age to convince and reinforce the notion that all residents of Canada collectively belong to what Benedict Anderson (1983) referred to as an "imagined community". Expanding on the work of Harold Innis (2007, 2008), Maurice Charland (1986) similarly argues that both CBC and the Canadian Pacific Railway provide 
different examples of "the paradoxical promise of democracy and domination inherent to the rhetoric of technological nationalism" (p. 33) and that "Canada is a state which must constantly seek to will a nation in its own image, in order to justify its very existence" (p. 32). As put by Patricia Cormack and James F. Cosgrave (2013),

Technologies do not so much unite Canadians in dialogue as bring Canadians into existence through the experience of communications technologies themselves - without irony, the CBC's 'Canada Lives Here' slogan pulls Canada into the network of transmission lines, airwaves, and fibre-optic cable. In this sense, the experience of listening to or viewing the $\mathrm{CBC}$ is more important than what is actually being broadcast at that particular moment (p. 27).

From the undeniably nationalistic tone of the 1968 version of the Broadcasting Act which specified that $\mathrm{CBC} /$ Radio-Canada "contribute to the development of national unity and Canadian identity", to the comparatively nationalistically-tame "maintenance and enhancement of national identity and cultural sovereignty" mandate for $\mathrm{CBC} /$ Radio-Canada specified in the most recent 1991 version of the Act, CBC/Radio-Canada's mandate has consistently hinged on promoting and supporting the concept of Canada as a unified community. The Broadcasting Act similarly lends $\mathrm{CBC} /$ Radio-Canada the legitimacy and authority to operate as Canada's national public broadcaster by way of its adherence to what Max Weber deemed "rational-legal" procedure (as quoted in DeLanda, 2006, p. 30). As such, CBC/Radio-Canada's authority as purveyors of Canadiana is wholly administrative (Raboy, 1990) and susceptible to change by an act of Parliament.

While it is a challenge to quantify $\mathrm{CBC} /$ Radio-Canada's success at maintaining and enhancing "national identity and cultural sovereignty", $\mathrm{CBC} /$ Radio-Canada itself suggests that 
its operations as a public broadcaster can be measured through the evaluation of the following four "pillars":

- "creating and delivering original and innovative, high-quality Canadian content"

- "reflecting and drawing together all Canadians"

- "actively engaging with audiences"

- "being cost-effective and accountable"

(CBC/Radio-Canada, 2015d)

According to $\mathrm{CBC} /$ Radio-Canada, if the above-noted four outcomes are being met by the public broadcaster it can be considered to be fulfilling its mandate to "contribute to shared national consciousness and identity" (Canada, 1991, Section 3. (1) (m) (vi)). Leaving the important evaluation of whether or not CBC/Radio-Canada television is "accountable", and whether or not its programming represents "original and innovative, high-quality Canadian content" to others, this dissertation focuses specifically on the "delivery" component of CBC/Radio-Canada's first pillar commitment to Canadians and the "cost-effective" component of its fourth pillar commitment in relation to its ongoing television operations. The reason for this is that these two pillar commitment components most closely align with Section 3. (1) (m) (vii) of the Broadcasting Act which details the mandated delivery of CBC/Radio-Canada services throughout Canada. Furthermore, this dissertation focuses on CBC/Radio-Canada television delivery rather than on $\mathrm{CBC} /$ Radio-Canada television programming since, as noted by Harold Innis (2008),

A medium of communication has an important influence on the dissemination of knowledge over space and time and it becomes necessary to study its characteristics in order to appraise its influence in its cultural setting. (p. 33) 
What is at stake for $\mathrm{CBC} /$ Radio-Canada following the 2012 shutdown of its analogue OTA television service is the shifting nature of its role in "the maintenance and enhancement of national identity and cultural sovereignty" (3. (1) (b)) within a "post-TV" (Strangelove, 2015), public service media (PSM) digital landscape. As Gaëtan Tremblay (2016) asks, “(i)n the age of digital networks and an abundance of programs and services of every kind, is there still a place for public service media?" (p. 192).

To date, $\mathrm{CBC}$ /Radio-Canada's approach to this digital challenge has entailed a sharpened focus on the creation of Canadian television programming and a marked move away from its direct provision of citizen access to its television services via publicly owned or controlled television delivery infrastructure. As $\mathrm{CBC} /$ Radio-Canada and other public service broadcasters (PSBs) around the world continue to adjust to an era of digitization and networked computing by recasting themselves as public service media (PSM), the research participants featured in this dissertation help to make visible and to inform the five elements of access to the public broadcaster's television programming as detailed in the Public M.A.P.S. model. Research interviews conducted with analogue $\mathrm{CBC} /$ Radio-Canada OTA television viewing households and $\mathrm{CBC} /$ Radio-Canada Management reveal how neo-liberal notions of television delivery efficiency (mainly that the market will best provide television services by way of reduced government regulation and the stimulation of greater competition amongst privately-owned television providers) affect citizen access to public television programming. Furthermore, the interviews conducted illustrate the impact $\mathrm{CBC}$ /Radio-Canada's heightened efforts at achieving television delivery efficiency has had on its ability as a public broadcaster to maintain and nurture the amorphous imagined community (Anderson, 1983) of Canada within an increasingly fragmented, user-oriented, twenty-first century digital media environment. 
This chapter has outlined CBC/Radio-Canada's response to meeting Canada's digital television transition deadline and set out the main overarching research question and four subresearch questions posed by this dissertation. This chapter has identified the 2012 shutdown of CBC/Radio-Canada's analogue OTA television service, prompted by the CRTC's 2011 transition deadline and eventually executed by $\mathrm{CBC}$ /Radio-Canada as a means by which the public broadcaster hoped to realize operational cost-efficiencies, and presents an opportunity to study post-analogue utilization of publicly-owned spectrum and infrastructure in the name of enhancing citizen access to $\mathrm{CBC} /$ Radio-Canada television programming (as measured by this dissertation's Public M.A.P.S. model).

Next, Chapter 2 of the dissertation details the history of Canadian household access to CBC/Radio-Canada programming spanning the period of 1936 to 2016. Chapter 2 also details a selection of relevant regulatory secondary sources related to the provision of $\mathrm{CBC} /$ Radio-Canada programming access to Canadians. Following Chapter 2, Chapter 3 provides insight into how CBC/Radio-Canada's 2012 response to Canada's digital television transition deviated from the CRTC's official mandatory digital television market transition plan for the country. Chapter 3 also includes illustrations that compare $\mathrm{CBC}$ /Radio-Canada's analogue OTA television coverage area to its digital OTA television coverage area and ends with insight into how a selection of public broadcasters in other countries went about completing their own digital television transitions.

A literature review of existing research relevant to this dissertation is offered in Chapter 4. Literature related to public service broadcasting, the maintenance of imagined communities, the public interest vs. consumer choice, vertical integration, disintermediation, participatory media, and notions of television delivery efficiency are discussed. Chapter 5 expands on this 
dissertation's methodology, research planning, research timeline, and provides insight into the challenges and opportunities related to the data collection period. Chapter 5 also details this dissertation's use of the political economy of communication (PEC) as its methodological approach.

Chapter 6 presents the findings from the primary research interviews conducted for this dissertation featuring $\mathrm{CBC} /$ Radio-Canada OTA television-viewing households and $\mathrm{CBC}$ /RadioCanada Management. A summary chart comparing the $\mathrm{CBC}$ /Radio-Canada OTA television viewing household findings and $\mathrm{CBC} /$ Radio-Canada Management findings, as related to the identified five elements of access to $\mathrm{CBC} /$ Radio-Canada television programming.

Chapter 7 discusses this dissertation's findings by returning to the central research question and four sub-research questions posed in Chapter 1. The discussion draws from the research findings featured in Chapter 6 in addition to secondary sources. Chapter 7 also features the Public Media Access Puzzle Sieve (Public M.A.P.S.) model developed by this dissertation and identifies areas for future research. Chapter 8 outlines the dissertation's conclusion and includes a summary of the key findings, the dissertation's research contribution, concluding recommendations, and concluding remarks. 


\section{Chapter 2: Access to CBC/Radio-Canada programming, 1936 to 2016}

This chapter provides insight into why CBC/Radio-Canada approached Canada's digital television transition in the manner that it did, the role that Canada's regulated broadcast system has played historically in the provision of access to CBC/Radio-Canada programming throughout Canada, and an overview of key shifts in CBC/Radio-Canada's television operations. Chapter 2 concludes with discussion of CBC/Radio-Canada's analogue OTA television network expansion that occurred in the first decade of the twenty-first century.

Notions of how best to deliver television across a country such as Canada are tied to historical processes of commodification (Mosco, 2004/2005). Commodification is defined as efforts at "transforming use value into exchange value" whereas the use value of a product is "the satisfaction of a specific human want or need" and exchange value as what the product "can command in exchange” (Mosco, 2009, p. 129). As Toby Miller (2007) explains with the following television delivery example, commodification of television delivery develops in scenarios where "the price paid for subscribing to cable or satellite access (exchange value) takes over from the programs being watched (use value)" (p. 7). The commodification of television delivery in a country such as Canada is also tied to, as Gregory Taylor (2013) notes, whether a national broadcast system is regarded as a "product or service" (p. 83). Any ambiguity on this differentiation can serve as a barrier to the provision of access to television programming.

The provision of access to $\mathrm{CBC}$ /Radio-Canada programming commenced with the delivery of CBC/Radio-Canada radio programming in the 1930s. The following section's condensed review of the build up to $\mathrm{CBC} /$ Radio-Canada as a radio broadcaster helps reveal why Canada first came to revise its regulation of spectrum under the Wireless Telegraphy Act of 1905 (Armstrong, 2010, p. 22) to also include federal regulation pertaining to domestic over-the-air 
radio broadcasting. This chapter also accounts for the ways in which $\mathrm{CBC} /$ Radio-Canada has attempted to make its television programming available to Canadians since 1952 and concludes with detail pertaining to the public broadcaster's response to Canada's 2011 digital television transition deadline.

\section{The dawn of CBC/Radio-Canada}

Ever since the Department of Marine and Fisheries licensing of the Montréal over-the-air AM radio broadcasting operations of the privately-owned Marconi Company in 1919 (Raboy, 1990, p. 21), Canada has been attempting to regulate the use of publicly-owned electromagnetic radio spectrum for over-the-air broadcasting. In terms of early radio regulation, Mary Vipond (1994) notes that "Canadian private broadcasters in the 1920s struggled with rising costs, inadequate financing, and regulatory flaws" (n.p.). In response, a Royal Commission on Radio Broadcasting (known as the Aird Commission named after its head, Canadian Imperial Bank of Commerce president Sir John Aird) was formed by then Prime Minister Mackenzie King in 1928 to review radio broadcasting in Canada with a mind to consider a "combination of the British and German systems" of radio broadcasting in contrast to the market-oriented U.S. radio broadcasting model (Raboy 1990, p. 7). As noted by Marc Raboy (1990), the Aird Commission and its resulting report "infused broadcasting with national purpose, thus establishing one of the central distinguishing characteristics of Canadian broadcasting. Canadian broadcasting policy would be a national policy and the system it directed would have a clearly national vocation" (p. 7). Indeed, the Aird Commission's 1929 report went so far as to call for "the end of private broadcasting in Canada in favour of a limited number of high-power stations owned and run by a government company", a recommendation made in part in the hope that it might "prevent the

further spread of American radio into Canada (many Canadians could receive American stations 
directly, and four Canadian stations were affiliates of NBC and CBS by 1930)" (Vipond, 1994, n.p.).

Marc Raboy (1990) points out that Canada's initial approach to the regulation of broadcasting followed Walter Lippmann's “general model for social organization” combined with the similarly paternalistic approach of the BBC's Sir John Reith to "give the public what we think it needs, not what it seems to want" (1990, p. 6). Raboy highlights a key Aird report recommendation that Canadian "broadcasting should be placed on a basis of public service and that the stations providing a service of this kind should be owned and operated by one national company" (1990, p. 28). As a result, Raboy argues that "ideas of 'public' and 'nationhood' thus became fused in the broadcasting policy implied by the Aird Commission's report and would remain that way" (1990, p. 7).

In contrast to Raboy's claim that the Aird report fused forevermore the ideas of the public and nationhood within Canadian broadcast policy, David Skinner's (2005) research into the early days of radio regulation in Canada instead stresses "the ingenuity of this scheme, with its focus on employing an economy of scale in transmission to provide an economy of scope in productive relationships" (p. 142) and argues that,

nationalization was foreseen by the Aird Report as a means of harnessing commercial interests to the public purpose of program production and distribution, as well as forging the interests of the listening public, private enterprise, and the Canadian state in common purpose (p. 142).

Following the Aird Commission's report, a subsequent radio broadcasting report created by a 1932 House of Commons Special Committee on Radio Broadcasting (formed by then Prime Minister R.B. Bennett) would come to serve as a guide for the government's Canadian Radio Broadcasting Act passed the same year (Vipond, 1994). As noted by Michel Filion (1996b), for the period "from 1905 to 1932, radio was, above anything else a commercial device" (p. 119) in 
Canada. It was during the 1932 House of Commons Special Committee on Radio Broadcasting hearing where Graham Spry famously noted that the decision about whether to establish a Canadian broadcasting system ultimately came down to "a choice between commercial interests and the people's interests. It is a choice between the State and the United States" (Raboy, 1990, p. 40). However, David Skinner (2005) disputes such a regulatory bifurcation, noting that, just as the development of both the Canadian economy in general and other Canadian media of the day were heavily influenced by American capital and technique, so too was broadcasting (Litvak \& Maule, 1974, pp. 18-23; Magder, 1993, p. 13). Moreover...the choice was not simply between public (or state) and private investment either. Instead, as the system developed, both regulation and the public broadcaster acted to buffer private broadcasters from the exigencies of the marketplace, extend the reach of private capital, and capitalize elements of the system that were beyond the reach of private operators. ( $p$. 137-138)

Robert W. McChesney (1999) similarly points out that Spry's bravado about the threat that radio broadcasting from the United States posed to Canadian sovereignty may have been fuelled as much by Spry's desire for the ideals of "democratic socialism than it was the result of his Canadian nationalism. His primary concern, arguably, was that a commercial broadcasting system disenfranchised the public and empowered big business, regardless of nationality" (n.p.). On a similar note, the following statement made by Prime Minister Bennett during debate in the House of Commons over the bill for the proposed Canadian Radio Broadcasting Act highlighted the importance of the prudent stewardship of Canada's air waves as a natural resource for use by "the people",

The use of the air, or the air itself, whatever you may please to call it, that lies over the soil or land of Canada is a natural resource over which we have complete jurisdiction under the recent decision of the privy council. I believe that there is no government in Canada that does not regret to-day that it has parted with some of these natural resources for considerations wholly inadequate and on terms that do not reflect the principle under which the crown holds the natural resources in trust for all the people. In view of these circumstance and of the further fact that broadcasting is a science that is only yet in its infancy and about which we know little yet, I cannot think that any government would be 
warranted in leaving the air to private exploitation and not reserving it for development of the use of the people (Bird, 1988, p. 113).

While the Canadian Radio Broadcasting Act of 1932 did not result in the end of all private broadcasting in Canada (as per one of the Aird report recommendations), it did result in the formation of the Canadian Radio Broadcasting Commission (CRBC) which served as both federal radio broadcaster and federal radio broadcast regulator (Vipond, 1994). Mary Vipond (1994) notes that while the much-criticized CRBC was soon replaced by "its successor, the Canadian Broadcasting Corporation (CBC)" in 1936 as part of a new broadcasting act passed by the (once-again) Mackenzie King government, she points out that the CRBC nonetheless “introduce(d) a public element into the Canadian broadcasting system" (1994). As noted by Richard Bird (1988), the 1936 act "omits any reference to the purposes of broadcasting" and "ignores the French fact, despite the grief encountered by the CRBC when it attempted bilingual broadcasting” (p. 143).

\section{CBC/Radio-Canada's expansion into television broadcasting}

While domestic radio broadcasting in Canada commenced with privately-owned radio stations and involved the CRBC, and later the Canadian Broadcasting Corporation, playing regulatory catch up in terms of establishing a national public radio broadcaster, once over-the-air television signals also started to waft north across the U.S./Canada border, Canada felt that a publicly owned television system was warranted. As such, the early days of television broadcasting in Canada is very much the story of the country's public radio broadcaster CBC/Radio-Canada and the expansion of its service to include television broadcasting.

Early television broadcasting entailed a process of distributing television programming over-the-air (OTA) using analogue OTA television transmitters fixed to television antenna 
towers that would broadcast television programming through publicly owned spectrum by way of Hertzian waves. Households that had a television set and were located within the coverage area of local analogue OTA television transmitter(s) could receive OTA signal(s) with use of an indoor antenna (known colloquially as rabbit ears/oreilles de lapin) or with an outdoor roof-top aerial. The next section details the history of CBC/Radio-Canada television delivery, spanning analogue OTA television broadcasting to digital mobile wireless delivery.

\section{The Massey Report (1951)}

The genesis of analogue OTA television broadcasting in Canada associated with the Massey Commission included "the most extensive public discussion of communications in Canada up to that time" (Raboy, 1990, p. 93-94). Officially named the Royal Commission on National Development in the Arts, Letters and Sciences, the Massey Commission was established in 1949 by the then Liberal government of Louis St. Laurent and was tasked with recommending "the principles upon which the policy of Canada should be based, in the fields of radio and television broadcasting” (Raboy, 1990, p. 92). The Massey Commission’s May 1951 report "supported the cautious introduction of television under the firm control of the CBC" (Bird, 1988, p. 210). While Conservative opposition leader George Drew argued in the House of Commons in 1952 that the role of public broadcasting "should be concentrated in areas (programming and geographic) that would otherwise go uncovered", J.J. McCann, Minister of National Revenue, nonetheless announced that $\mathrm{CBC}$ would commence television broadcasting in the urban centres of Montréal and Toronto by September of that year (Raboy, 1990, p.110). On September 6, 1952, CBC commenced television broadcasting in Montréal care of CBFT, followed two days later in Toronto care of CBLT (CBC/Radio-Canada, 1977). For roughly the first 18 months of the public broadcaster's television operations in Montréal the station aired 
programming in both French and English, a programming strategy that Alain Saulnier (2015) claims "would be entirely impossible today" (p. 16).

By November 1952, a speech from the throne proclaimed that additional CBC television stations would be built in Ottawa, Vancouver, Winnipeg, and Halifax, in addition to announcing that "applications would be considered for private stations proposing to serve areas which could not be reached by the six CBC stations" (Raboy, 1990, p. 111). By December of that year, Minister McCann stated to Parliament that with the construction of these six stations, "there would be publicly-owned stations with some production facilities at least in each of the main regions of the country" (Bird, 1988, p. 241).

Roger Bird (1988) argues that this approach by the government to only fund the installation of a limited number of television transmitters owned and operated by the Corporation, and to rely on the transmitters of privately-owned $\mathrm{CBC}$ affiliates to deliver its television programming elsewhere in the country, hobbled the public broadcaster's television operations from the start:

The government never provided the CBC with enough money to carry out its assigned mission to build a CBC TV network that would dominate in the new medium. Instead, the CBC got funds for a skeletal chain of stations: Halifax, Montreal, Ottawa, Toronto, Winnipeg, and Vancouver. Private stations soon dominated the system, giving it strong local qualities combined with a flow of profitable and popular US programs. By the end of 1956, the country had eight CBC TV stations and 22 privately owned ones. (1988, p. 242).

Furthermore, Marc Raboy (1990) notes that this period of broadcast regulation also marked two key developments that did come to serve the public interest with regards to the Canada television broadcasting system. First, Raboy (1990) argues that the "Massey commission notwithstanding, the development of television would see the private appropriation of broadcasting away from the public sphere" (p. 94). The reason for this according to Raboy was that private industry argued at the time that it too could help serve the public interest with respect 
to television broadcasting and that disputed the notion that "only 'the government' could be said to serve the public interest" (1990, p. 94). As such, Raboy notes how "in the 1950s, the basic principles that had guided the first thirty years of Canadian broadcasting were rewritten as the underlying practices were reworked" (1990, p. 95). Secondly, by the time of the Massey Commission, Raboy argues that the Corporation "had developed its own bureaucratic survival instinct, which did not necessarily contribute to its public service mission" (1990, p. 96). According to Raboy, "CBC dominance, then, depended on defining the national interest as superior to local interests. It was a tactical position in a power struggle with the private interests and their supporters, but it had far-reaching political implications.... The conflict between the centre and the periphery - or regions - would become a leitmotif of Canadian broadcasting" (1990, p. 97).

\section{Broadcasting Act of 1958}

The Broadcasting Act of 1958, assented on September 6 of that year (Bird, 1988, p. 268), was the first revised broadcasting act to be passed since the commencement of Canadian television broadcasting exactly six years earlier. Under the 1958 Act, the Corporation's previous duties as regulator were severed and placed under the purview of a newly formed broadcasting regulator, the Board of Broadcast Governors (Armstrong, 2010, p. 35). The Corporation did however retain its role as a national broadcasting service. A partial list of its duties as related to the delivery aspect of its broadcasting service outlined in the 1958 Act follow below:

\section{Objects and Powers.}

29. (1) The Corporation is established for the purpose of operating a national broadcasting service, and in particular, but without restricting the generality of the foregoing, has power to 
(a) maintain and operate broadcasting stations and networks of broadcasting stations;

(b) establish, subject to approval of the Governor in Council, such broadcasting stations as the Corporation considers necessary or desirable;

(c) equip broadcasting stations with all such plant, machinery and other effects as it considers necessary or desirable;

(d) make operating agreements with broadcasting stations for the broadcasting of network programs;

(e) originate programs and secure programs, from within or outside Canada, by purchase or exchange and make arrangements necessary for their transmission;

(f) make contracts with any person, in or outside Canada, in connection with the production or presentation of the programs of the Corporation;...

(Bird, 1988, p. 279-280)

It is relevant to this dissertation to observe that while the newly formed Board of Broadcast Governors (BBG) was tasked under Part I of the 1958 Act with "the purpose of ensuring the continued existence and efficient operation of a national broadcasting system" (Bird, 1988, p. 272), Part II of the 1958 Act detailing the operations of the Canadian Broadcasting Corporation does not make similar mention of efficiency in relation to the Corporation’s “purpose of operating a national broadcasting service” (Bird, 1988, p. 279). Explicit mention of efficiency regarding the delivery of the Corporation's service would not appear until the most current Broadcasting Act of 1991. Instead, the Broadcasting Act of 1958 grants the Corporation the leeway to operate its broadcasting stations "as the Corporation considers necessary or desirable" (Bird, 1988, p. 280). As will be discussed in Chapter 3, that notions of efficiency would only become explicitly attached to the Corporation's programming delivery expectations as of the Broadcasting Act of 1991, supports Janice Gross Stein's (2001) assertion that the 1990s was a period of heightened “preoccupation with efficiency as an end" (p. 11). 


\section{The Corporation's 25th Anniversary}

An article penned by Graham Spry in 1961 to mark the public broadcaster's $25^{\text {th }}$

anniversary outlines how Canada's national broadcasting system had developed to that point.

The system as described by Spry at the time remains strikingly similar to today with respect to the television system's ongoing reliance on the (publicly subsidized) private television sector. As noted by Marc Raboy (1990), Spry called for a rejuvenation of the Corporation in the article, one that lessened its dependence on private stations to distribute its programming:

Spry recalled that the CBC - "an unique instrument of Canadian nationhood" - was not an inevitable creation, but a political choice. Parliament chose "a national, public service system," rather than a scattered system of local private stations, or an American-owned network, or a network based on the private sector. It was to be financed not by the taxpayer but by the audience.

But the intended system had turned into its opposite...Canada now had a system of "predominantly...local stations, many of high-power, subsidized and supplemented by the public sector".

Spry suggested, the key to a renewed national broadcasting policy would be the national network of stations owned and operated by $\mathrm{CBC}$, with reduced dependence on private stations for the distribution of national CBC programs. (p. 153-154)

This call by Spry for the Corporation to reduce its dependency on private stations as a means by which to deliver its television programming to Canadians, in favour of its own delivery network, was a prescient call and one that could have been similarly made in the years leading up to Canada's digital television transition. While only two privately owned CBC/Radio-Canada television affiliates remain as of September 2016, down from 30 affiliates in 1997 (Taras, 1999, p. 178), and the majority of private television broadcasters in Canada are now owned by private Canadian vertically integrated BDUs, the problematic television delivery system described by Spry back in 1961 nonetheless articulated the stage that had been set for future public television delivery in the country. From early on (the first privately-owned $\mathrm{CBC}$ television affiliate 
commenced broadcasting in Sudbury in 1953 (CBC/Radio-Canada, 2017)), the public broadcaster relied upon affiliated private television broadcasters to help deliver its television programming to Canadians (to the Corporation's detriment according to Bird, 1988). While private broadcasters were never directed by Parliament to commence television operations (as CBC had been in 1952), if private broadcasters wanted to operate a television station they were initially required to seek $\mathrm{CBC}$ affiliation from the Corporation in order to do so, representing an early form of the mandatory delivery of the public broadcaster's programming that BDUs would later be required to provide as part of their basic television packages. In time, the Corporation switched to largely relying on such regulation requiring private BDUs to deliver its television programming to the far corners of the country rather than on privately owned OTA television affiliates. In both cases, such television delivery arrangements by privately-owned intermediaries were the product of federal regulation.

\section{The Cable Television Conundrum}

A change to television delivery that partially prompted revisions to the Broadcasting Act of 1968 was cable television. Canadian cable television delivery, initially a means by which to deliver American television programming to Canadian households, commenced in London, Ontario in August 1952 (Anthony, 2002) - one month prior to the commencement of domestic OTA television broadcasting in Canada by the Corporation. As noted by Robert Armstrong (2010), cable television delivery to apartment buildings and homes "began to mushroom" in Canada by the late 1960s thanks to "the range of services available, particularly in areas bordering the United States, and because of the quality of reception, particularly for colour television" (p. 38). Canadian cable television providers would install master antenna systems 
(MATV) in order to receive available over-the-air television signals (initially limited to U.S.

OTA stations prior to the build out of the Corporation's network of television transmitters) and then relay the received OTA television signals to an individual subscriber's household via coaxial cable (Armstrong, 2010, p. 38).

Beyond ushering in the Canadian Radio-television Commission (CRTC) to replace the Board of Broadcast Governors (BBG) as Canada's broadcasting regulator, the Broadcasting Act of 1968 also extended broadcast regulation to include cable television. One of the reasons for this change was that unregulated cable television delivery had disrupted the regulated national television broadcast system for public and private broadcasters alike. Unregulated cable television was disruptive since cable television providers were not required at the time to distribute any Canadian television stations to subscribers. As noted by Marc Raboy (1990), comments made by CBC President Alphonse Ouimet at a 1961 Special Committee on Broadcasting reveal that the Corporation's main concern was that its television programming would be included as part of the emerging mode of cable television delivery that it did not have any control over:

In Ouimet's testimony, the classical argument for public control of broadcasting - that the "air" was a natural monopoly in the public domain - was shifted for the first time. Ouimet framed his argument in terms of "end effect" - the fact that whether the messages were sent out through the air or transmitted by means of wire they were ultimately received in people's homes. Consequently, "it would be in the national interest to have the same controls over the two kinds of system." As long as they were achieving exactly the same end, the problem of controlling the means was in both cases the same" (p. 146).

If broadcasting were now redefined in terms of "end effect" - which seemed remarkably close to saying broadcasting was to be defined in terms of its content - what was to stop the provinces from coming back with new claims that they should have control over these instruments of culture and education, especially those which could be confined to a given territory simply by establishing a wire head? [a wire head being a transmitter site] (p. 147). 
As noted above, by 1961 the Corporation appeared to be of the opinion that it no longer mattered how television arrived at a Canadian home (the means), whether by over-the-air radio waves or by cable TV wire. What mattered for the Corporation was that its television programming got there (the ends). Raboy (1990) notes that the Canadian Association of Broadcasters (CAB), a collection of private television broadcasters, was arguing the same thing at the time. Both the $\mathrm{CAB}$ and the Corporation were focusing on the importance of television content instead of on television delivery since they both viewed cable television as a threat (since neither $\mathrm{CAB}$ members nor the Corporation owned any cable television systems at the time and there was concern that cable providers would not offer their station(s) and that less people would watch them) and they wanted it regulated (Raboy, 1990, p. 147). Instead of starting up its own cable television service to deal with this threat, the Corporation wanted cable television operators regulated in the same fashion as television broadcasters, seemingly in the hopes that this would help address the "problem of controlling the means" of television delivery in Canada.

The regulation of cable television delivery expanded Canada's regulated national television broadcasting system to include modes of television delivery beyond over-the-air broadcasting. Since the "primary attraction" of cable television in Canada "was its ability to provide U.S. border television signals to Canadian households" (Armstrong, 2010, p. 44), regulation of cable television operators in Canada was, as noted earlier, an attempt to have cable television providers distribute Canadian OTA television stations. Simultaneously, through the 1960s and 1970s, Marc Raboy (1990) notes that "[t]echnological developments made it necessary to extend any discussion of "broadcasting" to include the wider sphere of 'communications"” due to "the spread of satellite and computer technologies" (Raboy, 1990, p. 226) . The Department of Communications (DOC), formed in 1969, was tasked to deal with 
"industrial and economic perspective and left the 'cultural' aspect of communications with broadcasting” (Raboy, 1990, p. 226). As argued by Raboy (1990),

The cable issue formed a bridge between broadcasting and telecommunciations and was the flash-point of conflict between "public" and "private" interests while the new CRTC struggled to formulate policy in its regard (p. 226)

As outlined by David Skinner (2008), 1968 to 1976 "are generally seen as a period of close management by the CRTC" (p. 6) with respect to the Commission's efforts to protect Canada's broadcasting system. In terms of the regulation of cable television delivery, Skinner (2008) notes that "the CRTC moved to make cable systems more responsible to the larger purposes of the system. Carriage rules were imposed to limit the import of distant signals and foreground the availability of the $\mathrm{CBC}$, local stations, and educational broadcasters" (p. 6-7). In terms of the regulation of cable television in other countries at around the same time, as part of a 1971 CRTC hearing on cable television "[t]he CRTC noted that cable systems had grown more rapidly in Canada than in the US, where the Federal Communications Commission has deliberately retarded their expansion in metropolitan centres" (Raboy, 1990, p. 210). The CRTC's justification for its own approach to cable systems according to Raboy (1990) was "to uphold the public interest and safeguard the overall system" in light of growth of cable in Canada (p. 211).

By 1976 the CRTC's duties related to the upholding of the public interest were expanded to include its regulation of telecommunications, creating the Canadian Radio-television and Telecommunications Commission (Skinner, 2008, p. 7). The CRTC did not however receive any budget increases to take on such additional regulatory responsibilities (Skinner, 2008, p. 7). The early 1970s also saw the licensing of Canada's first provincial educational public television 
broadcasters, Télé-Quebéc and TVO, expanding the delivery of public television broadcasting beyond the television services of the Corporation (Raboy, 1990).

\section{The Accelerated Coverage Program (ACP)}

In terms of the history of the Corporation's ability to deliver its television programming to citizens by way of publicly owned spectrum and publicly owned infrastructure, the public broadcaster's analogue OTA television service received a significant boost (as did its FM radio services) starting in the mid-1970s with the government's approval of the Accelerated Coverage Plan (ACP), an initiative aimed at extending OTA access to $\mathrm{CBC} /$ Radio-Canada television and radio programming. As detailed by Lorna Roth (2005),

In April 1974, the Cabinet approved $\$ 25$ million dollars for the extension of the CBC service in English or French to all Canadian communities with a minimum population of five hundred...Projected capital costs of the ACP were $\$ 50$ million. Half of this amount came from Cabinet appropriations and the other half came from the CBC budget (Feaver 1976, 54). The ACP annual operating budget was originally estimated to be $\$ 12$ million (Feaver 1976, 53). (p. 113)

The ACP was rather remarkable in terms of infrastructure spending on the part of both the government of Canada and the Corporation. Under the ACP, a Canadian community with as few as 500 residents was deemed worthy of receiving OTA television and/or OTA FM radio from the Corporation, without any requirement for a household to subscribe to a privately-owned radio or television service in order to gain such access to the public broadcaster's programming. However, the ACP was not exactly a boon for local programming, particularly in Canada's North. As noted by Roth (2005), of the communities that were short-listed as eligible to receive transmitter(s) under the $\mathrm{ACP}$, " $\mathrm{CBC}$ would contact the given community and present it with a choice between a Southern television package (with no plans for local programming input) or nothing at all" (p. 113). As of 1976, only one of the northern communities contacted, Igloolik, 
had declined the offer of a television retransmitter, though Igloolik did eventually accept a radio retransmitter (Roth, 2005, p. 114). While flawed, Lorna Roth (2014) notes that "(w)hat nation network services did do, however, was trigger the recognition in First Peoples themselves that they had to have access to media production and distribution processes in order to create their own presence on the airwaves" (p. 366).

Satellite infrastructure played a key role in the implementation of the ACP. As noted by Anne MacLennan (2011), “(i)n northern communities, the launch of the Anik A and Anik B satellites in 1972 and 1978, respectively, provoked both anticipation of the benefits of extended broadcasting service and anxieties over potential cultural threats posed by broadcasting originating largely from the South" (p. 64). MacLennan (2011) suggests that "CBC's purpose as a national unifying force likely took precedence over the special needs of Canada's diverse regions" (p. 64) in the North, akin to the manner in which CBC/Radio-Canada had historically "struggled to provide adequate service to the Canadian Francophone population" (MacLennan, 2011, p. 65).

It is important to remember that cable television delivery and regulation requiring that cable television providers carry programming from the Corporation in English and French, along with other television stations, already existed around the time of the launch of the ACP. Public funds were not allocated (directly or indirectly) to booming privately-owned cable television companies to assist the Corporation's efforts to unify Canadian television-viewing households. It was the public broadcaster that used public funds to invest in the construction of publicly-owned television delivery infrastructure. Even though cable television subscriptions were clearly on the rise in Canada during the ACP's decade long roll-out, OTA television delivery was still regarded 
by both the Corporation and the governments of the period as continuing to provide citizen access to the public broadcaster's programming.

\section{Direct-to-Home (DTH) Satellite Television}

Licensed CBC/Radio-Canada television delivery options expanded beyond OTA and cable television in Canada in the late 1990s to include Direct-to-Home (DTH) satellite television. DTH satellite television delivery entails a processes by which a household receives television by way of a satellite dish affixed to the side of a dwelling (or perhaps a nearby tree or fence post) that is capable of receiving (for a monthly fee) encrypted television downlinks from transponder(s) located on satellite(s) in Earth's orbit that are owned or leased by a DTH provider. As noted by David Skinner (2008), in 1993 the CRTC "took the first step to remove cable as the key distribution technology within the system and announced that it considered 'DTH satellite services to be an important vehicle for delivering services in competition to cable' (CRTC, 1995b). With these changes the CRTC announced the arrival of a new era of 'Consumer-Driven TV' (CRTC, 1993a)" (p. 9). This move by the CRTC was in part a delayed response to the "impending threat of foreign satellite broadcasters" that had started in the 1980s (Skinner, 2008, p. 6), the same threat that had been posed by unregulated cable television delivery decades earlier. By 1997, the CRTC had licensed two DTH entities to operate in Canada, Star Choice (renamed Shaw Direct) and ExpressVu (renamed Bell TV) and the period of 1998 to 2003 saw rapid growth in Canadian DTH such that the "(DTH) market share rose from 2.7\% to 23.7\%", while "cable's share fell from $97.2 \%$ in 1998 to $72 \%$ in 2003" (Skinner, 2008, p. 13). Canada's two DTH satellite television operators would come to play a key role in the delivery of $\mathrm{CBC} /$ Radio-Canada television programming following the digital television transition, 
particularly the DTH satellite services provided by Shaw Direct (as discussed in greater detail in Chapter 3).

However, an issue with DTH satellite delivery as flagged by CBC/Radio-Canada in terms of citizen access to its regional television programming pertains to DTH satellite providers not making feeds from all of its OTA television stations available to their subscribers. Despite a 2011 CRTC decision that expanded the number of CBC/Radio-Canada television stations that DTH providers must offer to their subscribers (CRTC, 2011c), CBC/Radio-Canada notes that DTH providers are still not providing sufficient access:

Starting September 1, 2011, satellite TV providers will be obligated to carry at least one TV station per province (and only 2 stations from the 4 Atlantic provinces) owned by each major Canadian broadcasting ownership group. CBC and Radio-Canada are considered to be two distinct ownership groups. While this is a step in the right direction, it will not guarantee citizens access to their local CBC or Radio-Canada station. That's because CBC and Radio-Canada operate multiple stations in certain provinces. The challenge is particularly acute in Quebec, where Radio-Canada operates six TV stations. Bell TV currently carries only three of those. Shaw Direct carries only one. But more than that, the current rules do not ensure a diversity of voices in that province: Shaw Direct, for example, carries five of the six TVA stations, and four of the five V (formerly TQS) stations.

(CBC/Radio-Canada, 2010)

While the introduction of licensed DTH satellite providers in Canada did expand the options available to many Canadian households in terms of their ability to access CBC/Radio-Canada television programming (although not always a household's local station, as outlined by CBC/Radio-Canada above, and also dependent on the terrain surrounding a household), CBC/Radio-Canada nonetheless continued to operate its analogue OTA television service into the twenty-first century. 


\section{Convergence and Vertical Integration}

The digitization of information, combined with networked computing care of the Internet, that coalesced toward the end of the twentieth century presented (the possibility) of new opportunities for citizen access to, and engagement with, public media. Digitization involves a process of converting information into binary - a series of ones and zeros - and allows content, including television programming, to be recorded, edited, stored, shared, and remixed in ways that were not possible in the analogue broadcast era. CBC/Radio-Canada was an early leader in Canada with regards to experimenting with offering content online, launching cbc.ca and radiocanada.ca in 1995 (CBC/Radio-Canada, 2017).

However, digitization also provided the basis for significant media industry convergence in Canada and around the world. Media industries that had been traditionally limited to providing content within a specific medium, such as print, radio, film, or television, expanded their operations to include other media (an expansion that often involved the purchasing of other media companies). As defined by Leslie Regan Shade (2005), convergence is "a touted yet nebulous strategy by the major media players, heavily promoted in the 1990 s, wherein the ownership of cross-media platforms and assets, particularly with the integration of digital technologies, aims to produce both vertical and horizontally integrated conglomerates" (p 110).

As argued by Dwayne Winseck (1998), the media industry convergence of the 1990s was more accurately a "reconvergence". Prior to the 1920s, North American telecom companies such as AT\&T in the United States and Bell Telephone in Canada were also involved in the radio broadcast and telegraphy industries (Winseck, 1998, p. 10). According to Winseck (1998), "the issues of media convergence now so prominent might have been settled in the 1920s and 1930s instead of the 1990s: The Bell Telephone Company might have developed on its early trials with 
radio to become not only the dominant telephone company in Canada but also the largest commercial broadcaster" (p. 10).

The first decade of the second millennium saw a significant jump in the vertical integration of Canada's media industries, thanks to corporate convergence (or reconvergence, as Winseck (1998) would argue) approved by the CRTC. In July 2000, the CRTC approved an application by OTA television broadcaster CanWest Global to purchase OTA Western International Communications (WIC) televisions stations (CRTC, 2000a). Canwest Global also purchased 50\% of the National Post newspaper chain that same summer (O'Brien, 2000). By December of 2000, the CRTC approved an application by telecom operator BCE to purchase OTA television broadcaster CTV (CRTC, 2000b), with BCE then forming Bell Globemedia along with the owners of the Globe and Mail newspaper, the Thomson Corporation and the Woodbridge Company (BCE, 2001). In 2001, the CRTC approved an application by Quebecor to purchase BDU Vidéotron (CRTC, 2001), after earlier approving Quebecor's application to purchase television broadcaster TQS (CRTC, 1997). In 2007, the CRTC approved an application by CTVglobemedia to purchase CHUM Limited (CRTC, 2007a). Later that same year, the CRTC approved an application from CanWest Global to purchase Alliance Atlantis Broadcasting (CRTC, 2007b), shortly before Global CanWest then declared bankruptcy in 2009 (Shade \& Lithgow, 2014, p. 182). 2010 was another particularly busy year for vertical integration in Canada with BCE's purchase of CTVglobemedia's assets (Shade \& Lithgow, 2014, p. 182) and Shaw Communications' purchase of CanWest Global's television stations (Gasher, Skinner, Lorimer, 2012, p. 264). The CRTC later approved an application from Shaw Communications to transfer its shares in Shaw Media (that included Global Television) to Corus Entertainment in 2016 (CRTC, 2016b). 
As noted by Gregory Taylor (2013), such deregulation of Canadian BDUs and the subsequent vertical integration outlined above resulted in a Canadian television system where BDU companies are now providing "no longer just pipes, but are increasingly content providers as well" (p. 84),

The widespread adoption of BDU services by the Canadian public has placed these distribution companies in the role of television gatekeepers for many citizens. Since BDUs are now often broadcasters as well, there is legitimate concern that carriage arrangements may favour vertically integrated BDU properties. As such, there is a strong correlation between BDUs and the public interest element within the Canadian broadcasting system; hence the necessity of regulatory oversight. (Taylor, 2013, p. 85).

Michael Strangelove (2015) similarly observes that "[t]he same companies that once controlled the distribution of television now also control the making of television" (p. 182), noting that BCE’s 2013 purchase of Astral Media for $\$ 3.4$ billion was done "in part to gain access to Astral's HBO Canada, The Movie Network and other television channels" (p. 176). Strangelove (2015) argues that what BDUs are seeking through such purchases is "control of access and the artificial creation of scarcity through copyright and legal regimes" (p. 182).

\section{IPTV Delivery in Canada}

With regards to BDU regulation in Canada, Internet-Protocol (IP) TV is the most recent mode of licensed television service. Distinct from television delivery by way of the open, public Internet, IPTV is a closed, private mode of television delivery that uses the same IP protocol as the Internet. From a household perspective, subscribing to and watching IPTV is largely no different than accessing TV through a cable connection (with many subscribers likely to be unaware that their TV signal is delivered using IPTV). IPTV has allowed traditional telecom providers to partake in a television delivery sector that cable television providers have traditionally dominated (Taylor, 2013, p. 103). Bell/Bell Aliant, MTS, SaskTel, and Telus were 
all licensed as IPTV BDUs in 2009 (Taylor, 2013, p. 103) and as of 2014 IPTV delivery

represented $14.2 \%$ of total BDU revenues (CRTC, 2015d, p. 130). While IPTV is still within its infancy with regards to availability in Canada, Gregory Taylor notes that Bell's Fibe and Telus' Optik IPTV services have been slowly building since 2010 and that the "development of fibre infrastructure vastly improves IPTV's service" as opposed to DSL delivery (2013, p. 104).

\section{Broadcasting Distribution Regulations}

A companion piece of Canadian television delivery regulation related to viewer access to CBC/Radio-Canada's television services, particularly in its post-analogue OTA television era, are Canada's Broadcasting Distribution Regulations. These regulations date back to the mid1970s and are the main reason why CBC/Radio-Canada ("the Corporation") was able to approach Canada's 2011 digital television transition as a cost saving initiative and to only install 27 digital OTA television transmitters within 20 Canadian television markets.

Under Section 17 (1) (a) of the Broadcasting Distribution Regulations, a terrestrial distribution undertaking licensee (defined as a distribution undertaking "other than a DTH distribution undertaking or a relay distribution undertaking"), must offer "the programming services of all local television stations that are owned and operated by the Corporation" (Canada, 1997). Furthermore, Section 17 (1) (d) notes that a terrestrial distribution undertaking licensee shall also distribute "the programming services of any regional television station that is owned and operated by the Corporation" if there isn't a local CBC/Radio-Canada station already offering programming in the same language. Lastly, if no local CBC/Radio-Canada station is available and no regional $\mathrm{CBC} /$ Radio-Canada station is available then the licensee, according to Section 17 (1) (f), shall offer "the programming services of at least one television station that 
broadcasts in English and at least one that broadcasts in French that are owned and operated by, or that are affiliates of, the Corporation" (Canada, 1997).

In short, as outlined above, all licensed Canadian terrestrial BDUs (including cable and IPTV distributors) must offer, at a minimum, at least one $\mathrm{CBC}$ Television station and one Télévision de Radio-Canada station as part of its basic service. While Canadian televisionviewing households must still subscribe to a terrestrial BDU in order to gain access to $\mathrm{CBC} /$ Radio-Canada, they will nonetheless receive $\mathrm{CBC} /$ Radio-Canada television programming in English and in French of some kind anywhere in Canada where terrestrial BDU television services are both offered and receivable by a household (once a signal connection with the household is achieved).

Furthermore, the Broadcasting Distribution Undertakings also outlines the requirement for availability of programming created by the Corporation that Direct-to-Home (DTH) distribution undertakings (ie, satellite television providers) must provide. These regulations are rather varied depending on the viewer's location. For DTH subscribers residing in Ontario, Quebec, Manitoba, British Columbia, Saskatchewan or Alberta, Section 46. 4. states that DTH operators "shall distribute as part of its basic services... [a] the programming service, to the extent that is available, one of each of the Corporation's English-language and French-language network television stations that originate in the province in which the subscriber's residence or other premises are located" (Canada, 1997). As for DTH subscribers in Canada's Atlantic provinces, the DTH provider under Section 5 "shall distribute as part of its basic services... [a] the programming service, to the extent that is available, two of each of the Corporation's English-language and French-language network television stations that originate in the Atlantic provinces", unless the undertaking does not have to provide local programming as part of its 
licence in which case it only has to carry one of the Corporation's programming services

(Canada, 1997). Lastly, in terms of the Northwest Territories, the Yukon and Nunavut, under Section 7 the DTH provider shall offer "[a] the programming services of at least one of the Corporation's Northern Television Services" (Canada, 1997).

\section{Internet and Wireless Mobile Television Delivery}

While the delivery of television over the Internet, care of an Internet Service Provider (ISP) or a mobile wireless provider, is not regulated as part of Canada's television broadcast system (the CRTC has maintained since Public Notice CRTC 1999-84 that "the Commission will not regulate new media activities on the Internet under the Broadcasting Act" (CRTC, 1999), it is nonetheless part of the history of $\mathrm{CBC} /$ Radio-Canada television delivery and is core to the twoway, user-based television programming mantra of public service media (PSM).

As noted earlier, CBC/Radio-Canada's online platforms cbc.ca and radio-canada.ca launched in 1995 (CBC/Radio-Canada, 2017). According to Pierre Bélanger (2005), “[t]he broadcaster's Web presence was launched more as an experimental project based on some inhouse technology aficionados' vision of what the Internet could do to extend the reach of radio and television content than as the result of a carefully laid-out strategic-development plan" (p. 411).

With regards to the live streaming of $\mathrm{CBC} /$ Radio-Canada programming online, $\mathrm{CBC} /$ Radio-Canada commenced online live streaming of its English and French radio services in September 1996 (CBC/Radio-Canada, 1997, p. 32). In terms of the availability of CBC/RadioCanada television programming online, the Corporation's annual report for 1996-1997 notes that "CBC Newsworld launched Canada's first television news service with real-time video on the Internet" on July 3, 1996 (CBC/Radio-Canada, 1997, p. 32). While the flagship French language 
television news program Téléjournal was made available "sur demande" at radio-canada.ca in 1999 (CBC/Radio-Canada, 2007), and both English and French regional websites featured "local information from all regions of the country as well as regional $\mathrm{CBC} /$ Radio-Canada Radio and Television programming" as of 2001 (CBC/Radio-Canada, 2001, p. 16), regularly scheduled live streaming/en direct online access to programming broadcast by CBC Television and Télévision de Radio-Canada (rather than live streaming of programming from the Corporation's subscription-based television stations such as CBC Newsworld - since renamed CBC News Network), did not commence until 2007 (N. Makoway, personal communication, June 30, 2016 and M. Tetreault, personal communication, August 1, 2016).

As noted by Gregory Taylor (2013), one of the earliest multi-channel live streaming television services in Canada was Richmond Hill, Ontario's iCraveTV which started offering its services in 1999 (p. 101). iCraveTV's business model was to capture OTA Canadian and U.S. television signals and stream them over the Internet via its website, accompanied by banner ads (Taylor, 2013, p.101). However, iCraveTV encountered legal trouble after both Canadian and U.S. OTA television broadcasters "sought legal action to prevent their product from being viewed over what they saw as an inferior distribution method" (Taylor, 2013, p. 101). While iCraveTV ceased operations in 2000 in order to avoid further legal action, Gregory Taylor notes that "the Internet is now a significant conduit for licensed programming that appears on company websites such as cbc.ca, ctv.ca, and globaltv.com" (2013, p. 102).

In terms of the type of participatory, user-based, online multimedia experiences celebrated by the likes of Henry Jenkins (2006), Lawrence Lessig (2008), and Lev Manovich (2002), CBC/Radio-Canada's English radio service (rather than CBC Television) launched the online multimedia website 120 seconds.com in June 2000 with the hope that it would become "a 
place where young Canadians will submit their own short films and share their stories" (CBC/Radio-Canada, 2000). By January 2001, CBC/Radio-Canada’s French radio service launched the online multimedia site Bandeapart.fm (CBC/Radio-Canada, 2001, p. 33). In March 2002, CBC Television launched the late night television program $Z e D$ and the online platform zed.cbc.ca. Launched three years before YouTube, ZeD's website allowed users to upload audiovisual media that they had made (referred to in North America as user-generated content or UGC) and to view content made by other users. Users could also watch television programming created by $\mathrm{CBC}$ Television via zed.cbc.ca and submit their work to $\mathrm{CBC}$ for possible future broadcast on the $Z e D$ television show. As noted on its archived website $(Z e D$ was cancelled in 2006), $Z e D$ "was created so that you could not just watch all the items you saw on TV, but also submit your own work for broadcast consideration. It's a match made in collaborative heaven" (CBC/Radio-Canada, 2006a). While CBC/Radio-Canada's early multimedia websites such as 120 seconds.com and zed.cbc.ca were highly experimental and provided opportunities for users to upload their own user-generated content in addition to watching CBC/Radio-Canada produced television programming, the post-ZeD era of CBC/Radio-Canada online video platforms skewed toward a tighter focus on CBC/Radio-Canada produced television instead of user-generated television programming.

In line with its renewed focus on professionally produced online television content, either created in-house by $\mathrm{CBC} /$ Radio-Canada or commissioned/acquired from elsewhere, $\mathrm{CBC}$ Television commenced the regularly-scheduled live streaming of its daily supper-time OTA television newscasts, along with CBC Television's flagship evening news show The National, in 2007 (N. Makoway, personal communication, June 30, 2016). In addition, a January 2008 report prepared for the CRTC notes that CBC was "live Internet broadcasting" Hockey Night in Canada 
at the time with a bitrate of $272 \mathrm{kbps}$ and a low video resolution of $320 \times 240$ (Sawyer, 2008, p. 48). While CBC Television's level of regularly scheduled live streaming remains tightly restricted as of September 2016, Télévision de Radio-Canada on the other hand has been live streaming approximately 90\% of its entire broadcast day since February 2011 (CBC/RadioCanada, 2014c).

With regards to $\mathrm{CBC}$ /Radio-Canada television delivery to wireless mobile devices, such delivery can be divided into three main categories: delivery by wireless service provider, delivery via Wi-Fi, and delivery by OTA broadcast. Apart from delivery to mobile devices by way of OTA television broadcast, as noted earlier, the delivery of television to mobile devices does not fall under the purview of the Broadcasting Act, as per the 1999 new media exemption order, although regulation(s) related to the Telecommunications Act may apply.

Early examples of the delivery of $\mathrm{CBC} /$ Radio-Canada content to cell phones involved the public broadcaster partnering with wireless service providers who would in turn make CBC/Radio-Canada content available to their subscribers. While the Corporation wasn't yet delivering television programming to cell phones, in the summer of $2000 \mathrm{CBC} /$ Radio-Canada was making content available via "(w)ireless WAP \& SMS messaging services to PDAs and cell phones" (CBC/Radio-Canada, 2003, p. 19). By the time of the 2004 Summer Olympics in Athens, CBC Television had "produced an exclusive Olympic video highlight package for delivery by Bell Mobility to its cell phone subscribers — an exciting broadcasting platform milestone and a first in Canada" (CBC/Radio-Canada, 2006b, p. 22).

With regards to the history of live streaming of $\mathrm{CBC} /$ Radio-Canada television to mobile devices (that as of September 2016 had come to include tablet computers, smartphones, 
smartwatches, and virtual reality (VR) headsets), the 2014 Sochi Winter Olympics was a

breakout year for the public broadcaster. According to CBC/Radio-Canada,

More than 10 million Canadians - 1 in 3 Canadians - watched our coverage via mobile platforms. Canadians consumed more than 17.5 million hours of video content offered live and on demand, and there were 2.6 million downloads of our Olympics app. (CBC/RadioCanada, 2014a, p. 5)

CBC/Radio-Canada's success with live streaming the 2014 Olympics television programming to mobiles devices even roused the praise of Conservative Senator Donald Plett as part of a 2014 hearing related to a Transport and Communications review of CBC/Radio-Canada. At the hearing, Plett noted that the 2014 Olympics was the "first time I ever watched it on computer, on my iPad, it was available wherever I went and probably got in the way of a lot of productive work for many people but nonetheless we all enjoyed it and so, thank you for that" (Canada, 2014, February 26). CBC/Radio-Canada continued its use of live streaming and ondemand television streaming as part of its television coverage of the 2015 Toronto Pan Am/ParaPan Games and the 2016 Rio Olympics/Paralympics Summer Games.

With regards to digital OTA television broadcasting to mobile devices, CBC/RadioCanada conducted testing of Mobile TV broadcasting in Toronto and Montreal in 2012 using the ATSC A/153, also known as ATSC M/H, standard (CBC/Radio-Canada, 2012e). Such television broadcasts can be received OTA, for no access fee, by mobile devices that have an ATSC Mobile TV tuner chip. CBC/Radio-Canada's findings from its Greater Toronto Area ATSC Mobile TV testing noted that "the signal was reliable from Burlington to Oshawa and up to Aurora in the North in a moving-vehicle and pedestrian outdoor evaluation" (CBC/RadioCanada, 2012e) and that "mobile DTV may be seen as a suitable and affordable substitute media platform, as more and more people are streaming television content on their cell phones using costly data plan” (Aubé, 2013). ATSC Mobile TV broadcasting by CBC/Radio-Canada has not 
been publicly reported since 2012, likely due in part to a lack of mobile devices in Canada capable of receiving ATSC Mobile TV signals.

Most recently, $\mathrm{CBC} /$ Radio-Canada has identified the viewing of its television programming on mobile devices as a top priority. The public broadcaster's 2014-2015 Annual Report identifies "Mobile" as the \#1 delivery platform for its future operations, followed in descending priority by "Online", "Radio", and lastly, "Television" (CBC/Radio-Canada, 2015a,

p. 14). CBC/Radio-Canada's current mobile delivery strategy is focused on mobile apps that users download (by way of a mobile wireless provider data plan or $\mathrm{Wi}-\mathrm{Fi}$ ) to mobile devices that support such apps (primarily mobile apps for Apple and Google Android devices). These apps, such as the CBC News app and the CBC Sports app, allow users to stream (by way of a Wi-Fi or wireless provider data plan) $\mathrm{CBC} /$ Radio-Canada multimedia content made available via the app including live streamed and archived CBC/Radio-Canada television programming. It is important to remember however that neither $\mathrm{CBC} /$ Radio-Canada nor BDUs are required to provide access to any of the above mentioned mobile television or Internet television platforms. The Broadcasting Act and the Broadcast Distribution Regulations do not mention or mandate any such modes of television delivery.

\section{CBC/Radio-Canada Analogue OTA Television Redux}

Prior to moving onto Canada's 2011 digital television transition and CBC/RadioCanada's response to the CRTC's transition deadline, it is import to mention the relevance of the Corporation's early twenty-first century analogue OTA television transmitter purchasing spree. As recently as 2008, CBC/Radio-Canada enhanced its analogue OTA television service when it expanded its roster of OTA television transmitters through a purchase of three privately owned analogue OTA Télévision de Radio-Canada affiliated television stations in Québec (CRTC, 
2008b). As part of CBC/Radio-Canada's application to the CRTC for approval to acquire the three former affiliate stations from TQS Inc., including a promise to convert the stations to digital (which it fulfilled), $\mathrm{CBC} /$ Radio-Canada advised that the purchase of the stations from TQS would allow the regional populations of Sherbrooke, Trois-Rivières, and Saguenay to continue to receive Télévision de Radio-Canada programming (CRTC, 2008a, p. 2). Furthermore, $\mathrm{CBC}$ /Radio-Canada had previously purchased $\mathrm{CBC}$ Television affiliate stations from CTV in Northern Ontario in 2002 and converted their transmitters located in Kapuskasing, Kearns, North Bay, Sault Ste. Marie, Sudbury, and Timmins for use as OTA retransmitters of its CBLT station (CRTC, 2002), adding even more analogue OTA retransmitters in the region in 2003 in order to further improve area access to the CBLT feed (Canadian Communications Foundation, 2013a).

This surge in CBC/Radio-Canada's purchasing of analogue OTA television transmitters in the first decade of the twenty-first century suggests that analogue OTA television delivery was indeed continuing to assist the public television broadcaster with the provision of access to $\mathrm{CBC} /$ Radio-Canada television-viewing households. Such twenty-first century use of analogue OTA television transmitters by $\mathrm{CBC} /$ Radio-Canada, in spite of overwhelming BDU subscription delivery dominance in the country, was emblematic of "Canada's long standing tradition of providing universal access to CBC television's main services" (Juneau, 1996, p. 98). As will be discussed in the next section, CBC/Radio-Canada's 2012 operational response to Canada's 2011 digital television transition deadline signalled a significant shift in the power relations related to $\mathrm{CBC} /$ Radio-Canada's tradition of providing universal access to its programming.

This chapter provided a selection of key moments in the provision of access to $\mathrm{CBC}$ /Radio-Canada programming spanning 80 years (1932 to 2016) with a specific focus on the 
provision of access to $\mathrm{CBC} /$ Radio-Canada television programming commencing in 1952 . From $\mathrm{CBC} /$ Radio-Canada television delivery by way of over-the-air (OTA) broadcast, cable delivery, direct-to-home (DTH) satellite delivery, and (Internet Protocol) IPTV delivery, numerous reports have been issued and regulatory decisions have been made by the Canadian government with the aim of making the public broadcaster's television programming accessible to Canadian households. Pathways to accessing $\mathrm{CBC} /$ Radio-Canada television programming have also expanded to include broadband Internet and mobile wireless service, albeit without the same mandatory carriage of $\mathrm{CBC} /$ Radio-Canada television programming via such online service providers. Instead, government regulation related to broadband Internet and mobile wireless service has largely entailed broader measures aimed at improving Canadian access to the Internet more generally rather than improving Canadian access to $\mathrm{CBC} /$ Radio-Canada television programming specifically.The next chapter provides greater detail pertaining to Canada's 2011 digital television transition and $\mathrm{CBC} /$ Radio-Canada's custom response to the national transition deadline. In addition, Chapter 3 provides insight into how select countries around the world went about completing their own digital television transitions and how public service broadcasters in those countries navigated the digital transition. 


\section{Chapter 3: Canada's 2011 Digital Television Transition}

The objectives of this section are to outline how Canada's approach to its digital overthe-air television transition came about, how CBC/Radio-Canada took a custom approach to completing its own digital television transition, and how CBC/Radio-Canada's approach to the digital television transition is tied to its ability to fulfill the delivery component of its mandate outlined in the Broadcasting Act.

Unlike early attempts at regulating Canadian radio broadcasting in the 1920s, and the start of regulated Canadian analogue television broadcasting in the 1950s, with the start of regulated digital television broadcasting in Canada $\mathrm{CBC} /$ Radio-Canada was no longer the centre piece of such new broadcast regulation. Although $\mathrm{CBC} /$ Radio-Canada started digital OTA television broadcasting in Montréal on February 21, 2005 (CBC/Radio-Canada, 2012h), privately-owned CityTV was the first Canadian broadcaster to start digital OTA television broadcasting almost two years earlier in Toronto on February 28, 2003 (Canadian Communications Foundation, 2013b). As such, the digital OTA television transition in Canada was a public and private broadcasting initiative from the start.

Canada's final digital television transition plan, as specified by the CRTC, required any OTA television broadcaster operating within areas of the country referred to as "mandatory digital television markets" to broadcast by way of the U.S. Advanced Television Systems Committee (ATSC) digital OTA television broadcast standard after August 31, 2011. The United States had previously switched its OTA television system to the ATSC standard in 2009. In addition, no full-power OTA television broadcasting (analogue or digital) in Canada was to occur between channels 52 and 69 (698 MHz to $806 \mathrm{MHz}$ ) after August 31, 2011 in accordance with the freeing-up of the $700 \mathrm{MHz}$ band of spectrum. 
As early as 1995, a Canadian Heritage Task Force on the Implementation of Digital Television, Chaired by then CBC executive Michael McEwan, was formed by the government (Taylor, 2013, p. 51). The Task Force's 1997 report recommended that the government set a hard deadline of 2007 for Canada to cease analogue television broadcasting in Canada (Taylor, 2013, p. 116). The Task Force's recommendation of an analogue shutdown at the end of 2007 was to occur three years after all OTA television broadcasters in Canada had started regular digital OTA television broadcasting (Canada, 1997b, p. 14). The idea behind this was that it "would allow broadcasters to simulcast their analogue services in one or more of the new digital formats and, concurrently, to explore the full potential of those formats" (Canada, 1997b, p. 12). In addition, this approach would also have given viewers across the country more time to adjust to the change and to report any challenges with respect to their ability to receive stations in digital. As noted by Gregory Taylor (2009), "(d)espite the decidedly pro-industry position of the report, the Task Force also clearly upheld the objective of universal service within the system" (p. 149). As articulated by the Task Force, universal service within the broadcast system was to "be preserved in the emerging digital system" by way of "(b)asic broadcast television services that are freely and universally available over the air" (Canada, 1997b, p. 35). While some broadcasters in Canada had their digital OTA television transmitters operational many years before shutting off their analogue OTA television transmitters, broadcasters in other markets 'straight-cut' from their analogue transmitters to their digital transmitters with no overlap of analogue and digital OTA signals. In such cases, OTA television-viewing households in Canada that were unable to receive the same Canadian television station in digital that they had been previously been receiving in analogue did not learn of the problem until the analogue OTA transmitter serving 
their community had already been shut down, abruptly cutting off the household's OTA television access and sending them scrambling for solutions.

Five years after the 1997 task force report was issued, the CRTC announced in 2002 that a "voluntary, market-driven transition model, without mandated deadlines" (Taylor, 2013, p. 116) would be Canada's approach to the digital television transition. When five more years passed with little progress, the CRTC announced in 2007 (the year which the 1997 task force report had previously proposed Canadian broadcasters would have already have been broadcasting in digital) that all Canadian television broadcasters would be required to cease analogue over-the-air (OTA) television broadcasting in mandatory digital television markets by August 31, 2011 (Taylor, 2013, p. 116-117).

Although Canada's specific digital television transition in mandatory markets deadline of August 31, 2011 was not established by the CRTC until 2007, as outlined above by Gregory Taylor (2013), Canada's digital television transition had been shuffling along for a number of years with little government involvement. Under an industry directed, hands-off neo-liberal market approach to achieving the transition, a decade passed while the CRTC hoped that Canadian OTA television broadcasters would have voluntarily transitioned from analogue to digital television broadcasting without the declaration of a hard deadline date (Taylor, 2013).

Once the market-driven approach was abandoned, a team of government departments was assembled to address the transition. As outlined by the Treasury Board of Canada, the structure of the government's "Digital Television Transition Team" was such that,

The complexities of this project required effective technical planning and close collaboration between several government departments and the private sector for months before the transition date. Canadian Heritage took the lead in communicating with Canadians; Industry Canada handled the technical issues; and the Canadian Radio- 
television and Telecommunications Commission established the date, scope and rules for the transition. (Canada, 2012, n.p.)

In accordance with the CRTC's final digital television transition plan of Canada, a plan that NDP MP and Digital Affairs critic Charlie Angus would come to describe as a "hodgepodge" effort (Canada, 2011, March 2), mandatory digital television markets in Canada were to include all provincial and territorial capitals, the National Capital Region and any television markets of 300,000 people or more (CRTC, 2010a). In addition, as noted earlier, no full-power OTA television broadcasting could occur between channels 52 and 69. However, by 2011 the CRTC had revised its list of mandatory markets to remove the territorial capitals of Yellowknife, Whitehorse, and Iqaluit from the list of digital television markets (CRTC, 2011184). The justification for the change given by the CRTC stated that, [T]ransmitters in Whitehorse and Yellowknife are located in small and remote markets, that they do not operate on channels 52 to 69 and that their continued operation would have no impact on television stations in adjacent markets. The Commission further notes that there are no full-power over-the-air analog television transmitters operating in Iqaluit that would be subject to mandatory conversion to digital. (CRTC, 2011-184).

A 2011 Canadian Press news story by Jennifer Ditchburn (2011) reported that "Digital TV transition goes off without much drama, heritage officials say: Digital TV transition a dud of a cliffhanger". The fact that the transition was more accurately a television market specific analogue shut down and not a true one-for-one swap of analogue for digital OTA television transmitters across Canada was beside the point. The point was that the CRTC had cleared selected portions of the valuable $700 \mathrm{MHz}$ band of electromagnetic radio spectrum that been used for analogue OTA television delivery for almost 60 years and that spectrum was now ready for Industry Canada to auction off. The fact that the vast majority of Canadian television viewers had been accessing their television through a BDU subscription service of 
one form or another for decades leading up the digital television transition certainly lent support to the notion that OTA television delivery, particularly analogue OTA television delivery, was well past its prime.

Early regulation of digital OTA television broadcasting in Canada is distinctive from both the early regulation of analogue OTA radio broadcasting and the early regulation of analogue OTA television broadcasting in the country in terms of the role that actual OTA audiences played in the event. Regulation that had seen the launch of $\mathrm{CBC} /$ Radio-Canada radio broadcasting, and later $\mathrm{CBC} /$ Radio-Canada analogue OTA television broadcasting in Canada, was formulated as a means to the end(s) of using Canada's publicly-owned spectrum and infrastructure to deliver radio and television programming to Canadians. In contrast, Canada's digital OTA television transition was largely focused on the Government of Canada clearing the $700 \mathrm{MHz}$ band of electromagnetic radio spectrum used for analogue television broadcasting. By 2014, this newly harvested $700 \mathrm{MHz}$ spectrum (a public resource) had been auctioned off by Industry Canada to the winning wireless service providers who had bid on blocks of available $700 \mathrm{MHz}$ spectrum to the tune of $\$ 5.27$ billion CDN (Industry Canada, 2015c). As summarized by Gregory Taylor (2013) "[t]he main priority of the Canadian digital television transition has been to protect legacy industries, rather than to explore new possibilities" (p. 50) and that "[t]he priority for the Canadian government was creating new sources of revenue, not enhancing the national broadcasting system" (p. 51).

Following Canada's $700 \mathrm{MHz}$ spectrum auction there was little further discussion of the merits of Canada's newly digital OTA television system in mandatory digital television markets and in rural non-mandatory digital television markets. It was not until the CRTC released its Let's Talk TV OTA television decision in January 2015 that there was any indication of a 
renewed regulatory discussion of how spectrum used for OTA digital television delivery might still hold value for Canadian OTA television-viewing households after all.

\section{Role of Shaw's Local Television Satellite Solution (LTSS)}

A key public discussion pertaining to the role that DTH satellite was anticipated to play in the post-analogue OTA delivery of television programming, including the delivery of CBC/Radio-Canada television programming, took place in early 2011 at an unrelated CRTC hearing regarding BCE's application to repurchase CTV Television Inc. (CRTC, 2010d). It was at the BCE hearing where Gregory Taylor cautioned the Commission that "it should not be required that Canadians purchase BDU services in order to access the medium of television" and that "[ $[$ the newly converged Canadian broadcasting market will not support OTA without encouragement from the regulator" (CRTC, 2011a). In response to Taylor's concerns, then CRTC Chairman Konrad von Finckenstein commenced the question and answer portion of Taylor's intervention as follows:

3663 THE CHAIRPERSON: Thank you.

3664 You are obviously very well conversed with our DTH policy. I am surprised, therefore, that you say on the second-last page, "Whatever the number, it should not required (sic) that Canadians purchase BDU services in order to access the medium of television".

3665 You surely are aware of our Shaw decision where we set $\$ 18$ million aside so that every Canadian who finds himself without OTA as a result of digital transition gets a free transmitter, free installation, free set-top box and will receive the signal that he received over-the-air before via television at no cost to him?

3666 DR. TAYLOR: Yes, I realized that recent decision in the Shaw decision, and I do think that it was a wise decision on the part of the Commission.

3667 But I do have some reservations about the access to satellite as opposed to over-the-air. Some people have expressed concern that the access to the satellite 
signal is really a way to entice people into the broader services of the satellite provider.

3668 THE CHAIRPERSON: Obviously it will be used for their purposes.

3669 DR. TAYLOR: Yes

3670 THE CHAIRPERSON: But, I mean, it is up to you to decide whether you want to just receive the OTA signal for free or whether you want to become a Shaw customer.

3671 DR. TAYLOR: Yes. And sorry that I am not clear on -- so will the Shaw program then be offered across Canada?

3672 THE CHAIRPERSON: Absolutely. That is the whole idea. Our estimation is, and you quite rightly point out, the numbers fluctuate, so we think it is roughly 35,000 and that amount of money should be more than ample to give every person a free set-top box, free installation, free dish and access to the OTA signal which he or she may be using.

The above-noted exchange between Taylor and von Finckenstein revolves around the post-analogue political economy of television distribution in Canada. von Finckenstein (somewhat condescendingly) questions Taylor's concern for access to OTA television signals following Canada's digital television transition, citing the CRTC's approval of the Shaw Direct Local Television Satellite Solution (LTSS) program tied to Shaw Communications' purchase of CanWest Global Communications Corp. a year earlier (CRTC, 2010c). According to von Finckenstein, since Shaw's LTSS would "give every person a free set-top box, free installation, free dish and access to the OTA signal which he or she may be using", Taylor and others should not be concerned about the CRTC's digital television transition plan or the availability of television programming following the transition. Shaw's LTSS program was thus positioned by the CRTC as a television delivery safety-net for areas of the country that would lose access to OTA television, including access to $\mathrm{CBC} /$ Radio-Canada television. As for Taylor's additional concern that the LTSS might serve as a gateway to paid Shaw DTH subscriptions, rather than a 
truly comparable replacement for OTA television delivery, von Finckenstein similarly dismissed Taylor, noting that "it is up to you to decide whether you want to just receive the OTA signal for free or whether you want to become a Shaw customer".

\section{CBC/Radio-Canada's response to Canada's 2011 Digital Television Transition deadline}

Prior to the CRTC's 2007 announcement of Canada's August 31, 2011 digital television transition deadline, the public broadcaster had already commenced digital OTA television broadcast testing in two television markets. CBC/Radio-Canada's first digital OTA television test transmitter, CBC Television's CBMT-DT, commenced operations in Montréal on February 21, 2005 (CBC/Radio-Canada, 2012h). This transmitter was followed by CBC Television's CBLT-DT and Télévision de Radio-Canada's CBLFT-TV test transmitters (both located in Toronto) on March 5, 2005, with Télévision de Radio-Canada's CBFT-TV Montréal test transmitter operational by March 22, 2005 (CBC/Radio-Canada, 2012h).

Despite such digital OTA television transmitter testing, CBC/Radio-Canada had been advocating to the CRTC as far back as 2002 that it be allowed to scale back its network of overthe-air television transmitters as part of its transition to digital television (Taylor, 2013). $\mathrm{CBC} /$ Radio-Canada had initially only wanted to serve Canada's 10 largest television markets with digital OTA television transmitters, arguing that it could reach $70 \%$ of Canada's population with such an approach (Taylor, 2013, p. 135). By 2007, CBC/Radio-Canada had expanded its OTA transition plan to include the use of 44 digital OTA television transmitters to deliver its television over-the-air across the country. CBC/Radio-Canada's digital television transition plan would then change again, eventually settling on 27 digital OTA television transmitters. 
Specific insight into CBC/Radio-Canada's digital television delivery strategy comes care of a 2012 memoir written by Richard Stursberg, past Head of English Services at CBC/RadioCanada, an executive role dedicated to ensuring that CBC's English Services fulfill its radio and television operations specified in the Broadcasting Act. Stursberg (2012) succinctly characterizes the vertically-integrated $\mathrm{BDUs}$ that $\mathrm{CBC} /$ Radio-Canada continues to be reliant upon for the mandated provision of household access to $\mathrm{CBC}$ /Radio-Canada programming in markets where it does not have transmitters as being "frenem[ies]" of the public broadcaster,

Whether we liked it, or not, we competed with the private broadcasters for audiences, revenue and talent. Our traditional competitors had become stronger still... [CTV]'s purchase by Bell meant that it not only had a parent with deep pockets, it had one that controlled extremely important platforms for the distribution of $\mathrm{CBC}$ services...It was now a frenemy, both a partner and rival... Shaw bought the CBC's other major competitor, Global...another frenemy to the CBC... Rogers, the cable and wireless giant, owned CityTV and Sportsnet. Videotron, the Quebec-based cable and wireless company, owned TVA (Radio-Canada's great competitor). (p. 288)

In contrast to vertically-integrated OTA television stations such as CTV, Global Television and City (as of September 2016 owned by the BCE, JR Shaw's Corus Entertainment, and Rogers Communications, respectively), $\mathrm{CBC}$ /Radio-Canada's digital OTA television service is the only television delivery infrastructure that it, or rather the Canadian public, owns and controls. To date, $\mathrm{CBC} /$ Radio-Canada has coped with this lack of publicly-owned BDU delivery infrastructure by way of the earlier-noted CRTC requirement that Canadian BDUs must carry at least one conventional CBC Television station and one conventional Télévision de RadioCanada station as part of any cable or satellite distribution package. As for Canadian ISPs and mobile wireless providers, neither have any regulatory requirements to provide Canadians with access to $\mathrm{CBC} /$ Radio-Canada television programming and $\mathrm{CBC} /$ Radio-Canada does not own or control and ISPs or mobile wireless providers. 
A few weeks prior to Canada's August 31, 2011 transition deadline, CBC/Radio-Canada applied for, and eventually received, permission on August 16, 2011, to continue to operate 22 of its analogue OTA television transmitters/retransmitters located in the following mandatory digital television markets (as defined by the CRTC) until August 31, 2012:

\author{
English-language television \\ CBRT-6 Lethbridge, Alberta \\ CBAT-TV Saint John, New Brunswick \\ CBAT-TV-2 Moncton, New Brunswick \\ CBLN-TV London, Ontario \\ CBLN-TV-1 Paris, Ontario (serving Kitchener-Waterloo) \\ CBMT-3 Sherbrooke, Quebec \\ CBJET Chicoutimi, Quebec \\ CBVE-TV Québec, Quebec \\ CBMT-1 Trois-Rivières, Quebec \\ CBKST Saskatoon, Saskatchewan \\ French-language television \\ CBRFT Calgary, Alberta \\ CBXFT-3 Lethbridge, Alberta \\ CBAFT-1 Saint John, New Brunswick \\ CBAFT-10 Fredericton, New Brunswick \\ CBHFT Halifax, Nova Scotia \\ CBAFT-5 Charlottetown, Prince Edward Island \\ CBFJ-TV St. John's, Newfoundland and Labrador \\ CBLFT-9 London, Ontario \\ CBLFT-8 Kitchener, Ontario \\ CBLFT-18 Thunder Bay, Ontario \\ CBEFT Windsor, Ontario \\ CBKFT-1 Saskatoon, Saskatchewan
}

(CRTC, 2011e)

The rationale for this extension, according to the CRTC decision, was that it would give " $\mathrm{CBC}$ an additional year to find solutions for viewers who may lose access to its over-the-air signals after the transition to digital television" (CRTC, 2011d). No other Canadian television broadcaster was granted such an extension. One of $\mathrm{CBC} /$ Radio-Canada's frenemies, $\mathrm{BCE}$, 
protested in vain $\mathrm{CBC} /$ Radio-Canada's request for the extension, citing "the significant investments that other over-the-air broadcasters have made in order to meet the 31 August 2011 deadline for conversion to digital in mandatory markets" (CRTC, 2011e). As for the $\mathrm{CBC} /$ Radio-Canada's hundreds of other analogue OTA television transmitters/retransmitters that were still operating outside of mandatory digital markets and outside channels 52 and 69 at that time, the $\mathrm{CRTC}$ had no requirement for $\mathrm{CBC} /$ Radio-Canada (nor any Canadian broadcaster) to shut down such analogue OTA television transmitters by any specified future date.

Soon after its digital OTA television transition extension was granted, CBC/RadioCanada advised the CRTC that it had a new plan. CBC/Radio-Canada announced that its final response to Canada's digital television transition would see it only convert its analogue OTA television transmitters to digital in television markets where it had originating television stations creating $\mathrm{CBC} /$ Radio-Canada television programming and not necessarily in accordance with the CRTC's transition plan based on mandatory digital markets. As noted in CBC/Radio-Canada's 2011-2012 Annual Report, CEO and President of CBC/Radio-Canada Hubert Lacroix advised that "the Corporation will be shutting down its analogue transmitters given the obsolescence of the technology" (CBC/Radio-Canada, 2012b, p. 48) and that shut down of its analogue OTA television service would yield savings of “\$10 million annually" (p. 17). Indeed, by July 2012, the CRTC approved CBC/Radio-Canada's Part 1 application to revoke the licences of two of its rebroadcasting television stations CBIT Sydney, NS and CBKST Saskatoon, SK that had previously taken $\mathrm{CBC}$ Television signals from different markets and repeated the signal to the surrounding community, and "to amend the licences for 23 English- and French-language television stations operated by the Canadian Broadcasting Corporation in order that reference to all analog transmitters be deleted", effective August 1, 2012 (CRTC, 2012c). All told, this 
change to CBC/Radio-Canada's television licence resulted in all of its (by then) remaining 607 analogue OTA television retransmitters being shut down and a final total of $27 \mathrm{CBC} /$ RadioCanada digital OTA television transmitters being installed within 20 Canadian television markets by July 31, 2012 (CBC/Radio-Canada, 2012a).

And with that, after operating a publicly-owned analogue OTA television service for just shy of six decades, $\mathrm{CBC} /$ Radio-Canada ended OTA television broadcasting in much of the country and commenced decommissioning its analogue OTA television transmitter/retransmitter sites. A list of the 27 digital OTA television transmitters (14 CBC Television and 13 Télévision de Radio-Canada) located in 20 Canadian television markets is provided below.

Table 1: CBC/Radio-Canada digital over-the-air (OTA) television transmitters as of August 2012.

\begin{tabular}{|c|c|}
\hline CBC Television & Télévision Radio-Canada \\
\hline Vancouver, BC CBUT 43 2.1 & Vancouver, BC CBUFT 26 26.1 \\
\hline Calgary, AB CBRT 16 9.1 & Edmonton, AB CBXFT 47 11.1 \\
\hline Edmonton, AB CBXT 42 5.1 & Regina, SK CBKFT 13 13.1 \\
\hline Regina, SK CBKT 9 9.1 & Winnipeg, MB CBWFT 51 3.1 \\
\hline Winnipeg, MB CBWT 27 6.1 & Toronto, ON CBLFT 25 25.1 \\
\hline Toronto, ON CBLT 20 5.1 & \\
\hline Ottawa-Gatineau, ON/QC & \\
\hline CBOT 25 4.1 & \\
\hline Windsor, ON CBET 9 9.1 & Montreal, QC CBFT 19 2.1 \\
\hline Montreal, QC CBMT 21 6.1 & \\
\hline Fredericton, NB CBAT 31 4.1 & \\
\hline Halifax, NS CBHT 39 3.1 & \\
\hline Charlottetown, PE CBCT 13 13.1 & \\
\hline Stown's, NL CBNT 8 8.1 & \\
\hline & \\
\hline & \\
\hline & \\
\hline & \\
\hline & \\
\hline & \\
\hline & \\
\hline
\end{tabular}




\begin{tabular}{|c|c|}
\hline- & Trois-Rivière, QC CKTM 28 13.1 \\
\hline- & Sherbrooke, QC CKSH 9 9.1 \\
\hline- & Saguenay, QC CKTV 1212.1 \\
\hline- & Rimouski, QC CJBR 45 2.1 \\
\hline- & Moncton, NB CBAFT 1111.1 \\
\hline
\end{tabular}

Source: (CBC/Radio-Canada, 2012h)

Significantly, after July 31, 2012, CBC/Radio-Canada was no longer able to offer its television programming by way of publicly owned spectrum or publicly owned/controlled infrastructure across much of the country. Chapter 7 of this dissertation outlines in detail the value of a public television broadcaster being able to self-distribute its own television programming via publicly owned infrastructure and the barriers to access that only become visible once a public broadcaster cannot provide such access to television-viewing households itself (as articulated by this dissertation's Public M.A.P.S. model). Following its unique response to Canada's digital television transition, CBC/Radio-Canada has become wholly reliant in the post-analogue era on its frenemy BDUs (particularly Shaw's LTSS program), mobile wireless service operators, and Internet Service Providers (ISPs) to make its television services available outside of the 20 television markets where CBC/Radio-Canada has at least one English or French digital transmitter operational. Furthermore, as noted by Gregory Taylor, the significance of this change in terms of the CBC/Radio-Canada OTA television antennas, towers, and tower sites that were associated with the public broadcaster's analogue OTA retransmitters, is that "[o]nce the infrastructure is let go, there is little budget or political will to bring it back" (2016, p. 356). This television broadcast reality is evident when comparing CBC/RadioCanada's past analogue OTA television transmitters network (see Illustration 1) and its current digital OTA television transmitters network (see Illustration 2). 
Illustration 1: CBC/Radio-Canada analogue over-the-air (OTA) television transmitters as of August 2011

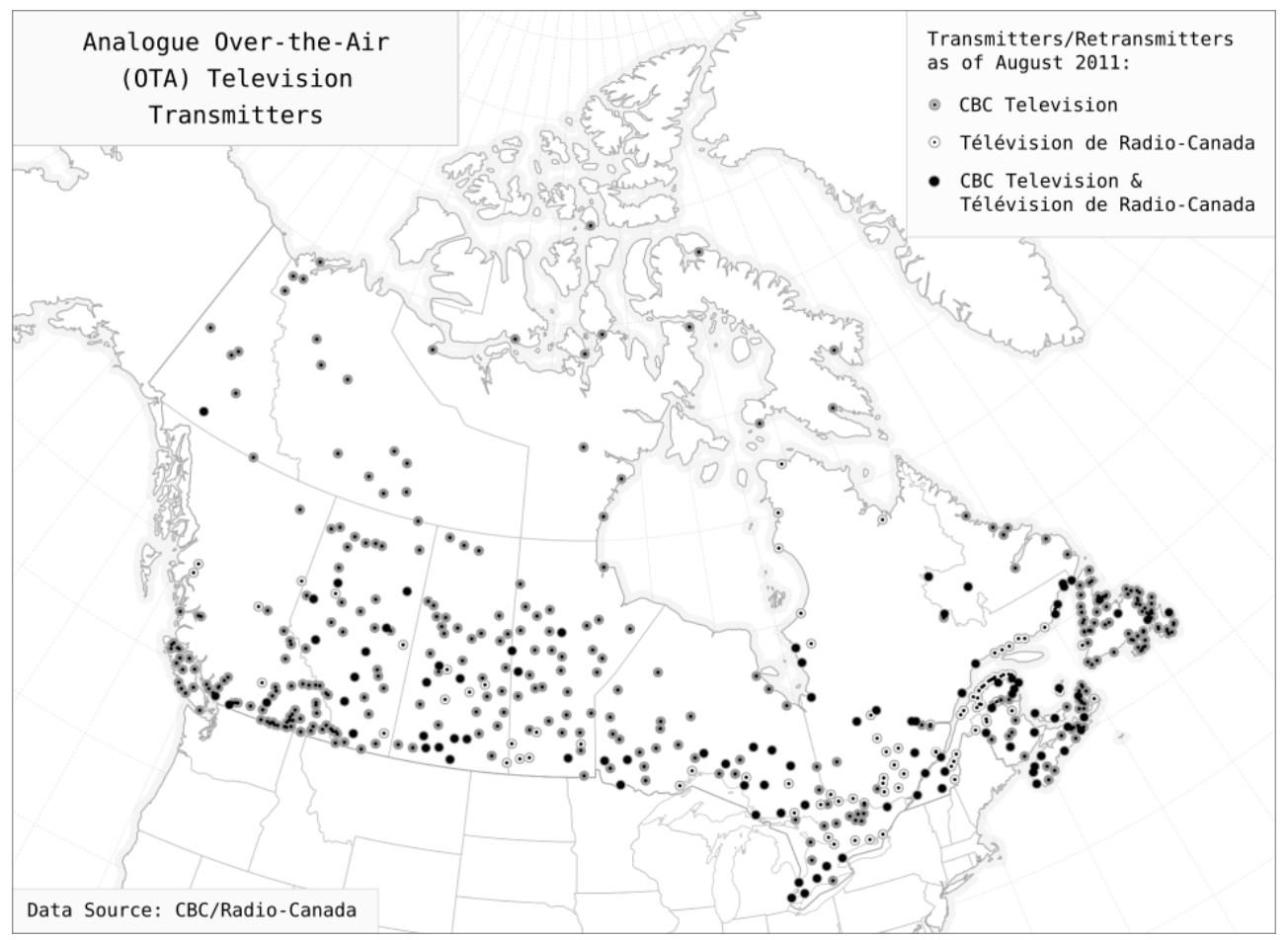

(CBC/Radio-Canada, 2012g)

(CBC/Radio-Canada, 2012j)

Illustration 2: CBC/Radio-Canada digital over-the-air (OTA) television transmitters as of August 2012

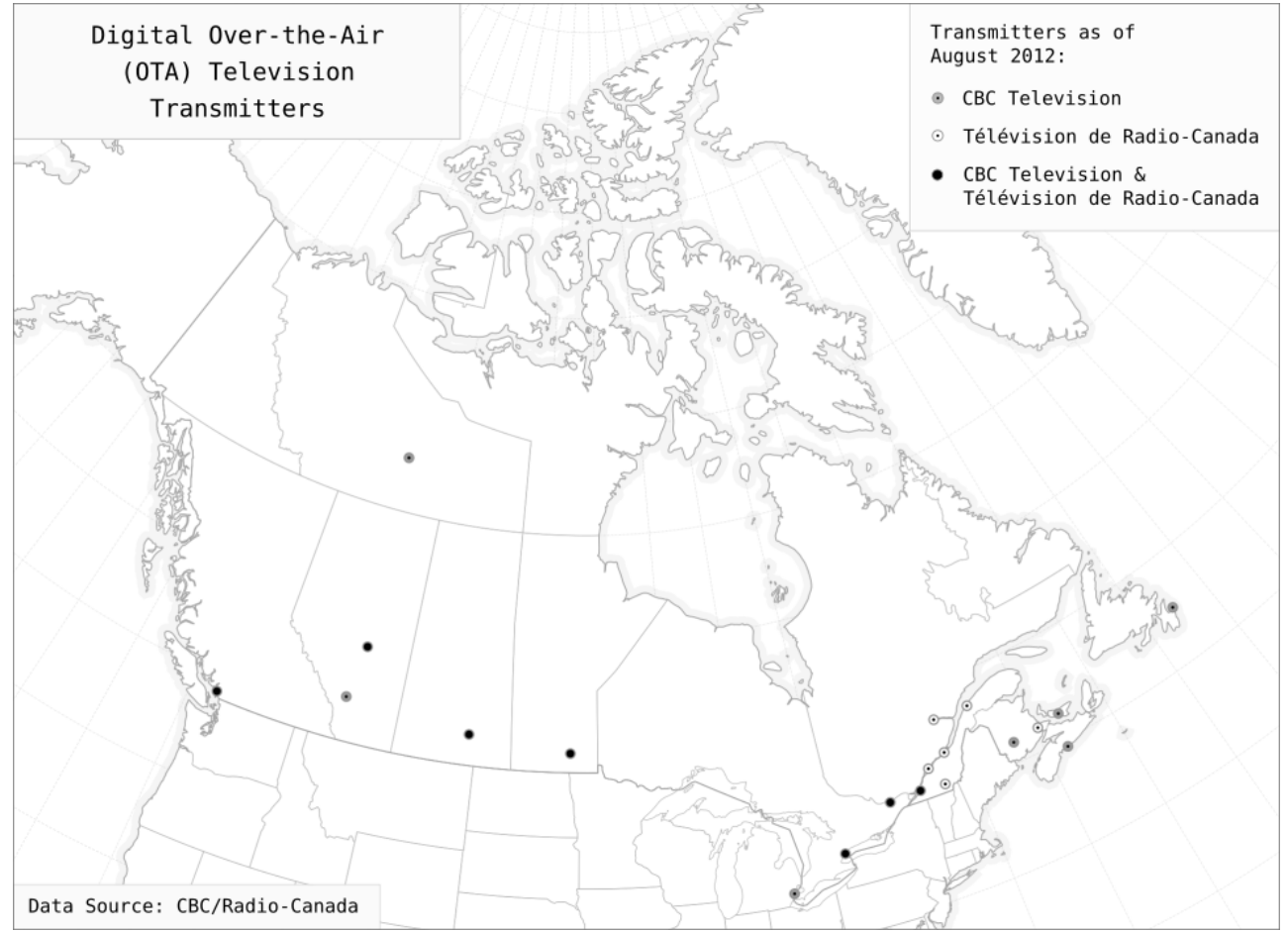

(CBC/Radio-Canada, 2012h) 


\section{Funding of CBC/Radio-Canada OTA television delivery}

As noted by Marc Raboy (1990), the additional costs associated with CBC/Radio-Canada's initial foray into conventional television broadcasting in 1952 were more than covered thanks to Canadian households purchasing their first televisions sets en masse,

Canadians were buying television sets at such a pace that the excise tax had produced more revenue than expected ( $\$ 11.7$ million in 1953-54) and the $\mathrm{CBC}$ had an operating surplus for television of about $\$ 5$ million. (p. 116)

Apart from these early years of CBC/Radio-Canada television broadcasting, CBC/RadioCanada has since struggled to financially support itself year to year. When the Broadcasting Act of 1958 received royal assent, the excise tax on television sets sold in Canada was rescinded and the public broadcaster henceforth received government funding by way of annual federal allocations, rather than every five years by way of a statue as was recommended by the first Fowler Report of 1957 (Raboy, 1990, p. 130). However, such annual federal allocations have never served to fully fund the public broadcaster nor were they ever intended to. It has always been understood by the government that CBC/Radio-Canada would need to seek additional sources of revenue each year (including revenue from the sale of television ads) in order to continue offering its public television operations. For example, as of 2014-2015 CBC/RadioCanada's annual report noted that roughly $63 \%$ of the public broadcaster's funding for that year was from its annual federal allocation, with the remainder comprised of advertising revenue, subscriber fees, and other sources (CBC/Radio-Canada, 2015a, p. 51). Advertising revenue represented $20 \%$ for 2014-2015, down from earlier years in large part due to CBC Television's loss of the broadcast rights to NHL hockey in 2014 (CBC/Radio-Canada, 2015a, p. 52).

While the first page of this dissertation cites CBC/Radio-Canada`s public statement attributing the shutdown of its 2012 analogue OTA television system to a federal funding cut 
made by the Harper Conservative government, twentieth and twenty-first century levels of federal funding allocated each year to $\mathrm{CBC} /$ Radio-Canada are not the primary focus of this dissertation. The reason for this is due to the fact that $\mathrm{CBC} /$ Radio-Canada has made it clear that it is no longer interested in spending its budget on the delivery of OTA television programming to Canadian households in the digital age - even if annual federal funding amounts were to increase. As noted by CBC/Radio-Canada Management interview MGMT004,

As we've moved through the 2000, 2005, 2010, 2011, 2012 period, government funding hasn't made any difference because even if we had been given a lot of money through that time frame, we would have used it to make programming. We wouldn't have used it to invest in a digital infrastructure that fewer and fewer Canadians were using.

$\mathrm{CBC} /$ Radio-Canada did not opt to reduce the amount of its spending on operating and maintaining its analogue OTA television transmitters in non-mandatory digital television markets where the continued operation of such transmitters might have been permitted (outside of the 700 $\mathrm{MHz}$ band) by the CRTC. Rather, $\mathrm{CBC} /$ Radio-Canada opted instead to completely end all spending on analogue television delivery and shut down its entire analogue OTA television service altogether. With respect to CBC/Radio-Canada's investment in its digital OTA television transmitters, the public broadcaster made it clear as recently as 2014 that it does not regard such an expenditure to be in the public interest and has sought to cease operating its digital OTA television transmitters entirely in favour of BDU and/or online delivery of its television programming by other intermediaries (CBC/Radio-Canada, 2014b, p. 9). CBC/Radio-Canada's plan since 2012 has been to take funds that had previously been spent on television delivery and put such funding towards the creation of television programming. Indeed, by September 2015, CBC/Radio-Canada President and CEO Hubert Lacroix was reporting that this strategy had yielded programming fruit for the public broadcaster, noting that "(i)n 2015, we were able to reinvest $\$ 23$ million from our savings into Canadian programs, the first time that we have been 
able to reinvest in our schedules since 2009" (CBC/Radio-Canada, 2015c). While a 2016 federal budget tabled by the newly elected Justin Trudeau Liberal government included a proposal "to invest $\$ 675$ million in the Canadian Broadcasting Corporation/Radio-Canada to disseminate and support world-class Canadian content and to provide Canadians with better access to programs and services in the digital era" (Canada, 2016, March 22, p.185), such a statement of financial support for the public broadcaster did not sway Lacroix from his in-progress digital strategy that commenced under Conservative Prime Minister Stephen Harper. The response Lacroix made to the Corporation's employees the day after the Liberal's proposed 2016 federal budget announcement argued that this new "(financial) stability means we can continue our digital transformation and invest in the programs and services important to Canadians" and that the Corporation's employees were "creating a closer connection with Canadians, on every platform, on every device they own" (CBC/Radio-Canada, 2016a). Such an operational philosophy regarding the delivery of $\mathrm{CBC} /$ Radio-Canada television to Canadian households is the reason why this dissertation does not focus on annual federal funding allocations to the public broadcaster. While additional federal funding will certainly assist CBC/Radio-Canada overall, the public broadcaster has made it clear that additional federal funding will not assist $\mathrm{CBC} /$ Radio-Canada in enhancing the OTA delivery of its television programming to Canadian households since it is not interested in spending funds on the OTA delivery of its television programming to Canadians.

While digitization has allowed $\mathrm{CBC} /$ Radio-Canada to direct funds from programming delivery toward programming itself, this has also shifted the delivery of its television programming throughout the country. Although Richard Stursberg (2012) was fired from CBC/Radio-Canada in 2010, prior to Canada's 2011 digital television transition deadline, and he 
was certainly no fan of OTA television transmitters, his following historical assessment of the Corporation's television delivery provides insight into the task of making programming accessible to all of Canada in the digital age,

The CBC had historically controlled the distribution of its shows. It owned its own transmission infrastructure of towers beaming out radio waves. The transmissions were picked up by cable and satellite companies and retransmitted to the audiences unchanged, with the shows still scheduled in the time-honoured blocks of morning, daytime, prime time and late night. But now it was all going away. The CBC did not own the new transmission platforms. It did not own YouTube or Facebook or Twitter or iTunes or Xbox or Netflix or Google TV or any of the others. If it were going to make its shows available in these new environments, it would have to develop partnerships with people operating novel platforms. (p. 284-285)

While Stursberg accurately notes that CBC/Radio-Canada does not own any of the above-listed American online platforms/services that allow users to view television programming on demand (provided such television is not geo-blocked to Canadians), he curiously does not include in his platform the public broadcaster's owned and operated cbc.ca and radio-canada.ca platforms. Furthermore, CBC/Radio-Canada's owned and controlled OTA television transmission infrastructure is described by Stursberg in the past tense only. This is no surprise since Stursberg once pondered eliminating all OTA transmission by CBC/Radio-Canada (in favour of satellite delivery) as a cost-cutting measure during the Great Recession of 2008-2009 (Stursberg, 2012, p. 265-266).

BDU television subscriptions have historically been a popular option by which the majority of Canadian households have accessed their television (including CBC/Radio-Canada). However, following Canada's digital television transition a BDU television subscription became required for many of the OTA television-viewing households interviewed for this dissertation if they cared to regain access to Canada's national public television broadcaster. While CRTC Chairman Jean-Pierre Blais reported in September 2016 that 177,000 Canadians had signed up to 
a so-called Skinny basic BDU television package as of June 30, 2016 following the CRTC's introduction of new BDU regulations related to basic television service in March of that year (Canada, 2016, September 7) it is yet to be determined how well the program will provide the public broadcaster's programming to households in comparison to the Corporation making such television programming available throughout the country OTA without the need for BDUs, ISPs, or mobile wireless telecom mediators. The fact that the Commission held a hearing in September 2016 (CRTC, 2016c) in response to complaints made against Canada's vertically-integrated BDUs about their implementation of new affordable basic television packages suggests that the post-analogue delivery of $\mathrm{CBC} /$ Radio-Canada via $\mathrm{BDU}$ still remains a work in progress. If the CRTC's new BDU television regulation fails to succeed as hoped, it may leave Canada's entire regulated television broadcast system short on solutions in terms of how to regulate and maintain a digital television system that exists first and foremost for the purposes of achieving the goals of national identity and cultural sovereignty. 


\section{Global perspectives on post-analogue public television broadcasting}

This section summarizes how other countries have been handling their own transitions to digital OTA television delivery and how they fared in terms of the continued provision of access to public television viewers. The digital television transitions in Australia and the United Kingdom are included in this section since those countries share historically similar public broadcasting traditions to that of Canada. The U.S. digital television transition is also featured in this section due to the United States' close geographic proximity to Canada and due to the fact that many aspects of Canada's digital television transition were guided in part by the 2009 U.S. digital television transition. Examining how other countries approached their digital television transition deadlines allows for added insight into the digital provision of access to $\mathrm{CBC} /$ RadioCanada television programming in Canada.

\section{Australia}

Australia's support for the provision of OTA television viewer access to the country's two public television broadcasters throughout its digital television transition was truly remarkable. Both of Australia's public television broadcasters, the Australian Broadcasting Corporation (ABC) and the Special Broadcasting Service (SBS), sought to replicate "the same coverage as their analogue services" as part of their switch to digital OTA television delivery (Hawkins, 2010, p. 290) and both ABC and SBS had their digital television transition costs fully covered by the Australian government (Given, 2015). As detailed by Jock Given (2015),

The full cost for the two publicly funded broadcasters, the ABC and SBS, was met through special appropriations on top of their ongoing funding - a fact the government constantly stressed when it was attacked for its cuts to ongoing funding (see Jolly 2014). This support for the national broadcasters' digital infrastructure totalled more than $\$ 900$ million in current prices, spread across the years from the early 2000s to 2007-2008, or around \$1303 million in 2014-2015 prices. Much smaller sums were also paid to reimburse the national broadcasters' 
contributions to an Interference Management Strategy run by the commercial TV broadcasters (DCITA 2006: 136). (p. 15)

In addition to providing funding to $\mathrm{ABC}$ and $\mathrm{SBS}$ to transition to digital OTA television delivery, the Australian government also funded the Viewer Access Satellite Television (VAST) service to help subsidize television viewers for the cost of new receiving equipment, the Analogue Television Black Spots Program established to maintain "terrestrial delivery of services to signal-deficient areas", funding to commercial television broadcasters, a special program to "assist the delivery of digital television to Australia's Indian Ocean Territories", and other subsidies and incentives to complete the switch to digital television delivery in the country (Given, 2015, p. 16). In contrast, the Canadian government did not provide any direct funding to cover the digital television transition costs incurred by $\mathrm{CBC} /$ Radio-Canada or any other Canadian television broadcasters. Similarly, the Canadian government did not provide any funding to Canadian viewers required to navigate Canada's digital television transition (although the CRTC's approval of Shaw's LTSS program, financed by Shaw Communications, did provide access to eligible households).

The popularity of OTA television delivery for Australia households remained strong leading up to the country's digital television transition. Only $29.2 \%$ of Australian households subscribed to a television service as of the fourth quarter of 2012 (Free TV Australia, 2014) compared to more than $80 \%$ of households subscribing to television in Canada around the same time. Subscription television (cable, satellite, and microwave delivery) is a relatively new mode of television delivery in Australia, having only been made available in the country as of 1995 (Herd, 2008, p. 77). As noted by Jock Given (2015),

Successive Australian governments and parliaments supported digital broadcasting because they accepted that a medium as popular as television needed a path to a digital future; they wanted spectrum to be used more efficiently and coveted the significant sums likely to be 
raised at auctions for the frequencies vacated; and they knew politically influential commercial broadcasters were keen on digital conversion (Alston 1998). (2015, p. 9).

Given's (2015) research reveals that Australia's efforts to ensure viewers would maintain access to their television following the transition were so elaborate that the country actually lost $\$ 333$ million AUS on its digital television transition (p. 18). While this loss might be attributed to the fact that Australia earned less than $\$ 2$ billion in auction revenues for its $700 \mathrm{MHz}$ band (Given, 2015, p. 18), this does not change the fact that the country headed into its television transition with an expectation that a substantial portion of the expected revenues from Australia's digital television transition would be put towards post-analogue television delivery initiatives.

While the costs incurred by Australian television viewers to purchase digital television displays and digital reception hardware can be amortized over time and may continue to provide television programming for years to come, the Australian government made a concerted effort to ensure that such households would also be able to receive a signal with such digital receiving equipment. The government's interest in the transition continued after its completion, including the production of a quarterly report Digital Track which aims to "find out why people were or were not switching to digital over the last five years of the transition" (Given, 2015, p. 10). In terms of television delivery success, as a result of the quarterly reports, the government was able to determine that "reception problems were common: 1 -in-7 or 8 consumers cited this as a negative over the last four years of the transition. This suggests the large investment of government money to ease the transition, especially for the most vulnerable consumers, was justified" (Given, 2015, p. 10).

While the Government of Australia took a loss on Australia's digital transition in terms of the digital dividends achieved via the country's $700 \mathrm{MHz}$ spectrum auction, Given notes that 
such a loss analysis does not take into account "the net benefits to society" $(2015, \mathrm{p}$. 18). A

broader analysis would, according to Given, need to,

take into account benefits such as those derived from the expansion of free-to-air television services and improvements in reception that are not captured by the financial amounts bid for vacated spectrum, including the long-awaited 'equalization' of TV services across Australia, the simplification of aerials required by consumers and the near-standardization of coverage by all broadcasters in each area. $(2015$, p. 19)

In addition, Given notes importantly that the fact that not all of the available $700 \mathrm{MHz}$ spectrum was auctioned off in Australia helps question notions of spectrum scarcity and whether there truly is a shortage of available spectrum to support mobile wireless services at the expense of spectrum for digital OTA television (Given, 2015, p. 18). Given notes that Australia's digital television transition shows that "[o]ver the life of the project, broadcast television's cultural and political power waned while mobile communications' rose. This kind of conflict may be common in the future as governments seek to continuously re-optimize the use of radiofrequency spectrum" (Given, 2015, p. 20).

The example of Australia illustrates how the country's approach to its digital television transition made a serious effort to address the television delivery costs accrued by televisionviewing households and not simply a focus on the government revenues to be harvested by the reallocation of spectrum previously used for analogue television broadcasting. The Australian government also fully funded the digital television transition of its two national public broadcasters, ensuring that if nothing else, at least they had the flexibility to explore completing their own digital television transitions most appropriate to their mandates.

With regards to the shift from public service broadcasting (PSB) to public service media (PSM) in Australia, Gay Hawkins (2010) notes that in the case of ABC, its shift to PSM has meant that "it has become less monolithic in terms of representing a unitary national public or 
public good. Its national agenda is now heterogeneous and dispersed across a serves of media institutions, working across multiple platforms, territories and constituencies", bringing $\mathrm{ABC}$ more in line with SBS that Hawkins (2010) argues has maintained its traditionally strong multicultural presence as part of its expansion into online offerings (p. 289).

\section{The United Kingdom}

Michael Starks (2007) notes that the approaches taken by individual EU members to completing their respective digital television transitions has varied widely, in part due to the status of public broadcasting in each country,

The result has been a very varied set of experiences in different European countries, reflecting different market sizes, the balance between platforms, the pattern of competition, the availability of terrestrial frequencies, the strength of the desire to safeguard public broadcasting and/or to foster broadcasting pluralism, and the degree of focus on re-using released analogue spectrum for other purposes. (p. 170)

In terms of the United Kingdom (an EU member at the time of its digital television transition), "around three-quarters" of UK households were accessing their television over-theair as of the late 1990s (Starks, 2013, p. 56). Starks (2013) also notes that "[t]he UK's digital transition proved a lengthy one, with analogue switch-off towards the end of 2012 following 14 years after the launch of digital terrestrial in late 1998" and that "BBC leadership and licence fee funding were central to the whole transition" (p. 55). Starks (2013) outlines the transition plan developed by the UK public broadcaster BBC following a failed earlier attempt at a UK digital transition by the bankrupted ITV Digital:

The BBC had concluded that the market could not support three-way competition between satellite, cable and terrestrial platforms for pay-TV subscribers. Its digital terrestrial television recipe was fewer channels, better coverage, quality services and no subscription. This, of course, suited its own public services, which were financed by the licence fee, but would require an open market in unsubsidised receivers available for a modest price. In order to implement this strategy the $\mathrm{BBC}$ would need multiplex partners and a close working relationship with 
receiver manufacturers and retailers (p. 58).

Ultimately, the BBC partnered with Crown Castle, "the company which had taken over BBC transmission when it had been privatised" (Starks, 2013, p. 56), along with BSkyB to offer the Freeview service described below,

The Freeview consortium duly won its bid and, in place of just the four or five analogue services, offered terrestrial viewers a line-up of around 30 standard definition TV services which included all the new BBC channels, plus ITV 2, ITV News, Sky News and Sky Sports...The main character of the UK's digital terrestrial platform was free-to-view. Following its launch in October 2002, supported by extensive BBC promotion, Freeview proved a runaway success and claimed two million customers by the end of its first year of operation. (Starks, 2013, p. 59).

In addition, $\mathrm{BBC}$ and $\mathrm{UK}$ regulator Ofcom also developed the $\mathrm{BBC}$-administered and licence-fee funded “'Help-Scheme' for the elderly and disabled, which offered practical assistance in installing set-top boxes as well as a financial subsidy for those who qualified on grounds of need" (Starks, 2013, p. 61).

EU collaboration related to the allocation of spectrum post-analogue is also of relevance to this dissertation. A report commissioned by the European Union (EU) referred to as the Lamy Report after its author Pascal Lamy (2014), provides additional insight into how spectrum allocations tied to digital television transitions are happening outside of Canada. While the EU set an analogue to digital television transition deadline for member states of January 1, 2012, roughly the same as Canada's, and most European Union countries completed their transition to digital over-the-air television, referred to as digital terrestrial television (DTT), by the end of 2013, unlike in Canada, the United States, Australia and elsewhere, the $700 \mathrm{MHz}$ band of spectrum remained in use when EU member states shifted from analogue to digital conventional television broadcasting. EU countries are debating how to reallocate its UHF band (470 to 790 
$\mathrm{MHz}$ ) which includes the $700 \mathrm{MHz}$ band (694 to $790 \mathrm{MHz}$ ) currently used for DTT. As noted in the Lamy report, "[t]he original UHF broadcasting band (470-862 MHz) is a valuable asset for ubiquitous and cost-efficient network deployment, whether for terrestrial broadcasting or mobile" (2014, p. 2). According to Lamy the maintenance of citizen access to television played a key role in the decision,

The European audiovisual model has provided citizens with a broad range of quality programming, free at the point of access (so-called free-to-air) and fulfills major public policy objectives such as cultural diversity and media pluralism. This is particularly important for the most vulnerable in society and must be maintained. In most EU Member States digital terrestrial television (DTT) represents the backbone of this model (2014, p. $3)$.

For a country like the US that is currently in the process of reallocating its $600 \mathrm{MHz}$ band of spectrum for use by wireless telecom providers, and for Canada that has been eyeing a similar repurposing of its $600 \mathrm{MHz}$ band, the EU model for the digital use of spectrum illustrates that the achievement of wireless mobile efficiency does not require the erosion of access to television broadcast signals. The Lamy reports also describes a "principal future scenario...based on platform co-existence, not convergence" $(2014$, p. 6). This approach contrasts the approach of Canada taken since the late 1990s that has put faith in vertically-integrated Canadian media companies to serve the public interest.

Furthermore, the Lamy report also stresses "cost compensation for the broadcasting sector upon any vacating the $700 \mathrm{MHz}$ band as it would carry the burden of ensuring continuation of its services through costs network re-configuration within a certain deadline and within a reduced amount of spectrum" (2014, p. 6). While the FCC in the United States used this approach of compensating conventional television broadcasters via a 2016 reverse auction in exchange for having to/offering to vacate the $600 \mathrm{MHz}$ spectrum, there has been no such similar discussion in Canada. Lamy notes that "[t]he cost impact on consumers also needs careful 
planning and mitigation" (2014, p. 6), a discourse that once again in Canada is not as vibrant as perhaps in the EU. In a future-proofed approach, Lamy ultimately calls for "a compromise which foresees coordinated repurposing of the $700 \mathrm{MHz}$ band to mobile services while linking it to reassurances for the sustainable development of terrestrial broadcasting in spectrum below the 700 MHZ band" (2014, p. 6).

In terms of other recent digital television delivery regulation that has occurred in the EU, the World Radiocommunication Conference decided in November 2015 that the 600 $\mathrm{MHz}$ band of spectrum (specifically $470 \mathrm{MHz}$ to $694 \mathrm{MHz}$ ) would remain dedicated to OTA television broadcasting (referred to as Digital Terrestrial Television or DTT) in Europe, Russia, the Middle East and Africa until 2023 (Digital TV Europe, 2015, November 27). This decision was similar in approach to the Lamy report which stressed that the "lower UHF range should be protected for broadcasting until at least 2030" (Lamy, 2014) prior to any decisions being related to the reallocation of additional UHF spectrum to mobile telecom use, as is already underway in the United States and has been proposed in Canada. Contrary to claims by mobile telecom association GSMA that reallocating the band to mobile telecom would mean that "legacy television services in the band can be delivered far more efficiently using less spectrum" and that "consumer habits are evolving as video content is increasingly accessed via mobile devices" (Digital TV Europe, 2015, November 27), the move by the WRC to keep the $600 \mathrm{MHz}$ band for television broadcasting indicates the value of broadcasting as a television delivery service across EU member countries and that EU countries need the flexibility to focus on completing their respective digital television transitions without having to worry about reallocating spectrum yet again, and actually “encourage(s) investment in DTT" (Digital TV Europe, 2015, November 27). 


\section{The United States of America}

The digital television transition in the United States was of great interest to its northern geographic neighbour. Beyond the fact that Canada decided in 1997 to adopt the U.S. ATSC digital OTA television standard as the official digital OTA standard for Canada, as of 2009 "more than 20 per cent" of English language television viewed in Canada was "directly" via U.S. OTA television stations (Taylor, 2013, p. 31). While HD television broadcasting first commenced in the United States as early as November, 1998 (Sterling, 2008, p. 57), the country did not complete its digital television transition until June 12, 2009 following the granting of an extension issued over concerns that millions of television-viewing households in the U.S. were reportedly still not ready for the transition (Parks, 2013b, p. 4).

While a coupon program was offered in the United States, allowing coupon holders to apply for a partial refund following their purchase of a digital OTA converter box, this program suffered from its share of problems:

By December 2008 the coupon program had run out of funding and an estimated 2.6 million people remained on the coupon waiting list. While 44 million coupons had been distributed, only 18 million had been redeemed (Hart, 2008). Informal economies emerged as a result. The $\$ 40$ coupons expired after 90 days of receipt, but they were transferable. Thus local churches and community organizations began to collect and redistribute unused coupons as a way of helping those on the waitlist or others who needed them (Parks, 2013b, p. 8).

Lisa Parks (2013b) identifies a particularly paternalistic discourse that accompanied the 2009 digital television transition in the United States. While the aim of helping the elderly and the poor dominated the reasoning behind the U.S. digital television transition delay, the importance of maintaining a "viewer body count" (in other words, maintaining a critical mass of television viewers which would allow television broadcasters to justify their TV commercial spot rates to advertisers) for the industry also played a significant role in the extension: 
What this discourse conceals is how deeply dependent the US commercial television industry is on a viewer body count. A substantial loss in numbers of viewers threatens to compromise the business model of US commercial television. Since the Nielsen rating samples are randomly drawn, each and every viewer in each and every household counts. (2013b, p. 9)

As outlined by Parks, a big part of the push to achieve a successful analogue to digital OTA television transition in the United States and the strong interest in maintaining OTA viewer access came from private television broadcasters concerned that the loss of any viewers would affect their ability to charge advertisers on a per-eyeball metric. This interest from industry in maintaining a robust viewer body count in the U.S. helps explain why television broadcasters in the United States spent $\$ 697$ million on educating the American public about the U.S. digital television transition whereas the U.S. communications regulator, the Federal Communications Commission (FCC), only spent $\$ 3$ million on its own educational campaign (Parks, 2013b, p. 9). In terms of public OTA television broadcasting in the United States, the public service broadcast model in the U.S. is different from the public broadcasting models in Australia, Canada, and the E.U.. The U.S. Public Broadcasting Service (PBS) is a non-profit that is privately owned by more than 350 independent US Public Service Broadcasters (PSBs) and was founded relatively recently in 1969 (Baer, 2010, p. 259). While PBS stations receive funding from the non-profit Corporation for Public Broadcasting (CPB), which itself receives annual appropriations from the U.S. Congress, CPB funding only represents on average 14 per cent of total funding for PBS stations (Baer, 2010, p. 260). In addition, instead of making its own television programming, PBS programming comes from nine television stations that sell shows to the public service (Baer, 2010, p. 260). With regards to meeting the U.S. digital television transition requirements, Walter S. Baer (2010) notes that PSBs "raised" $\$ 1.5$ billion to make the transition to digital OTA broadcasting (p. 262). Baer also notes that "(m)ulti-casting opens up 
opportunities for PSBs to advance their public service missions by offering more educational, civic, children's and other local content to their communities, as well as programmes in languages other than English" (2010. p. 262).

This chapter has mapped CBC/Radio-Canada television delivery over the course of 60 years, highlighting the requirements for $\mathrm{CBC} /$ Radio-Canada to provide programming across the country and showing the role that publicly-owned spectrum and infrastructure has played in providing such access along with significant changes to spectrum use in Canada in relation to the country's digital television transition. This chapter also turns to the digital television transitions in other countries for insight into alternative approaches that had a strong focus on the maintenance of viewer access to public broadcasting.

This chapter notes that Canada's digital OTA television transition was first and foremost about harvesting spectrum for uses other than OTA television broadcasting and that this placed a strain on the provision of viewer access to CBC/Radio-Canada television programming. This shift in use of spectrum and licensing regulation set up what happened following the shutdown of CBC/Radio-Canada's analogue OTA television transmitters and shifted the delivery of $\mathrm{CBC} /$ Radio-Canada television to Canadian television viewing households. The market was expected to deliver television to any disconnected analogue OTA television viewers (including $\mathrm{CBC} /$ Radio-Canada viewers). Such an approach to the delivery of television services by the CRTC and CBC/Radio-Canada alike is symptomatic of an interpretation of serving the public interest that skews heavily toward a trend of offering improved choice to Canadian consumers and less about serving citizens whose public interest(s) lay beyond the scope of consumers (Skinner, 2008). 
The next chapter details the literature review, the role that serving the public interest has played, and continues to play, in the regulation of Canada's broadcasting system, attempts at defining the public interest, how the public interest is tied to notions of public television delivery efficiency, and CBC/Radio-Canada's remodelling from a public service broadcaster (PSB) to a public service media (PSM). 


\section{Chapter 4: Literature Review}

The gap between the haves and have nots, the digital divide, bows to the far more powerful reality of a digital divine, which helps to overcome, almost magically, major divisions and disruptions in the world today (Mosco, 2004, p. 62).

This chapter draws from the tradition of critical communication studies as manifest in the work of critical scholars. Specifically, this chapter turns to literature that is critical of the promise of digital convergence as prophesized in the late twentieth century in order to account for the provision of access to $\mathrm{CBC} /$ Radio-Canada television in a post-analogue media environment. As noted by Sheryl N. Hamilton (2014), critical scholars "view social power as unequally distributed and generally subscribe to a conflict-based model of social relations that focuses on struggle and difference rather than on agreement and consensus" (p. 8-9). In addition, Hamilton (2014) notes that "all critical thinkers share an opposition to the liberal pluralist notion of social power, which sees power as neutral and potentially equally shared" (p. 9).

As Vincent Mosco (2004) notes at the top of this chapter, the benefits inherent to the seemingly utopian "digital divine" have largely overshadowed the digital divide that accompanies convergent shifts from analogue to digital technologies. Pippa Norris (2001) breaks down the digital divide into the following three elements,

The global divide refers to the divergence of Internet access between industrialized and developing societies. The social divide concerns the gap between information rich and poor in each nation. And finally within the online community, the democractic divide signifies the difference between those who do, and do not, use the panoply of digital resources to engage, mobilize, and participate in public life. (p. 4).

This dissertation's case study of CBC/Radio-Canada's response to Canada's 2011 digital television transition deadline is particularly helpful then in gauging the status of what Norris (2001) refers to as the "social divide" experienced by the "information poor" in Canada. As 
explained by Darin Barney (2005), “(i)n societies such as Canada's, where ICTs [Information Communications Technologies] have become increasingly important for participation in mainstream social, economic, and political life, differential levels of access to these technologies can be a significant source of inequality, forming a 'digital divide' between those who have access and those who do not" (p. 154). Importantly, Barney (2005) also notes that the digital divide is not simply limited to whether or not someone has a communications link to the outside world (although Barney acknowledges such a connection is a basic first step),

Even after connectivity is established, people experience serious inequalities in terms of how they use this medium (as passive consumers or as active contributors); in their capacity (skills and literacies) to use these technologies in ways that contribute to, rather than diminish, their autonomy; and in their ability to influence (either individually or collectively) the development, design, content, and regulation of the medium and its applications" (p. 155).

Daniel Paré (2005) has similarly discussed the information poor, noting that the digital divide is more accurately a "compendium of interrelated social, economic and technological considerations that influence Internet access and use" and that the singular notion of the digital divide "presupposes the presence of uniform imperatives for using technology and the deriving of uniform benefits from that usage" (p. 85). Paré (2005) instead favours a focus on "the processes associated with technological adoption as opposed to technology" (p. 89) - in other words, an emphasis on the divides aspect of digital divides (p. 88).

Research concerned with multi-layered digital divide(s) by Barney (2005), Paré (2005), and others typically address unequal socioeconomic levels of access to the Internet and mobile wireless services in Canada and around the world (for good reason). This dissertation extends such discussions of digital divides to also include access challenges related to citizens attempting 
to navigate the transition from traditional modes of one-way, passive, analogue television broadcasting to two-way, active, digital modes of television access.

While Nicholas Negroponte (1995/2001) observed that the shift to digital entails a transition from a world of atoms to a world of bits, Vincent Mosco (2003) cautions that Negroponte's "end of history comes with the end of an analog world of atoms, with its course, confining materiality, and welcomes the digital world, with its infinitely malleable electrons able to transcend spatial, temporal, and material constraints" (p. 27). As Mosco (2003) points out, being digital (Negroponte, 1995/2001) hardly constitutes a digital utopian existence freed from any limits imposed by the atomic world. What digital convergence has presented however is the potential for a formerly linear analogue public broadcaster like $\mathrm{CBC} /$ Radio-Canada that has historically relegated the role of Canadian households to that of passive audiences to instead offer active, two-way, participatory, user-centred public service media experiences. As noted by David Rowe (2011), "since the highlight of the paper fanzine, the digitization of media technologies has created many more opportunities for interactivity rather than straightforward reception and new ways of exceeding the usual spatial 'footprint' of media use" (p. 64). Such opportunities for interactivity provided by digitization are opportunities only however and are contingent upon the provision of user access to such platforms.

Beyond the technological aspects of convergence, Henry Jenkins (2008) notes that "cultural convergence" involves a "shift in the logic by which culture operates" (p. 283) across different media platforms. However, Jenkins (2008) also notes that "(n)ot all participants are created equal" within this converged landscape and that "[c]orporations - and even individuals within corporate media - still exert greater power than any individual consumer or even the aggregate of consumers" (p. 3). A manifestation of such imbalances in power noted by Jenkins 
(2008) can be found in the unequal access of all citizens to such convergence. As will be discussed next, unequal access within converged media environments poses a problem for public service broadcasters that have a tradition of the provision of citizen access to its programming.

\section{Provision of Access to Public Service Broadcasting}

The Reithian call for public broadcasting to provide "the best of everything to the greatest number of homes", as stated by Sir John Reith in reference to the early 1920s radio service of the British Broadcasting Company of which he was the first Director-General (BBC, n.d.), identifies the two traditional core components of public service broadcasting. This early definition of public broadcasting outlines an expectation that a public broadcaster both identify and curate programming of quality ("the best") in addition to ensuring that such programming is delivered "to the greatest number of homes". Both are required, not one over the other. While measuring and assessing programming quality is always a subjective matter of taste, making it a challenge to quantify and evaluate the best programming other than by way of press reviews and annual award shows (themselves equally subjective assessments), measuring the number of homes that a public broadcasting serves can be achieved by collecting subscription numbers (for subscription based services), or, better yet, by contacting individual homes and asking whether a household is able to receive a particular public broadcasting service.

According to Robert Armstrong (2010), public broadcasting is typically "characterized by non-profit objectives, often government ownership, and the provision of some form of broadcast service 'in the public interest"” (p. 112). Furthermore, Armstrong describes public broadcasting as a "policy instrument that governments use [to attempt to correct] market failures generated by a broadcasting system that relies extensively on commercial activities" (2010, p. 
112). A 2006 Nordicity report commissioned by CBC/Radio-Canada defines public

broadcasting as follows,

The concept of public broadcasting originated out of the view held by many governments and citizenry at the introduction of broadcast communications in the 1920s and 1930s - a view that it was a public resource to which citizens should have universal access....Today, with the increasing array of commercial broadcast outlets available to viewers and listeners in Western countries, the role of public broadcasting is to provide media content that is universal in content, universal in access, independent from political and commercial influence, and of high quality. (p. 6)

In terms of early radio regulation of broadcasting in Canada, Roger Bird (1988) notes that the experience in Canada was unique when compared to early radio broadcast regulation in both the United Kingdom and the United States since "private stations did not exist in Britain" and "private stations were all that existed in the United States" (p. 115). As noted in Chapter 2 of this dissertation, the Canadian Broadcasting Act of 1936 formed the Canadian Broadcasting Corporation, "the Corporation", and tasked it to "carry on a national broadcasting service within the Dominion of Canada" (Bird, 1988, p.145). At the time, the Corporation's stewardship of the national broadcasting service encompassed both its own radio broadcasting operations in addition to the broadcasting operations of private radio broadcasters that were not owned by the Corporation.

Any references to the nature of the programming carried by the Corporation or private Canadian radio stations in the 1936 Act were limited to the Corporation's ability to "control the character of any and all programmes broadcast by Corporation or private stations", restrictions related to political broadcasts including a policy that noted "dramatized political broadcasts are prohibited" (Bird, 1988, p. 151), and subsequent amendments that prohibited any stations from broadcasting programming on the topics of birth control or venereal disease (Bird, 1988, p. 161). In terms of concerns related to the level of Canadian content (CanCon) made available by 
CBC/Radio-Canada, it wasn't until 1951 that an amendment to the Broadcasting Act "revived" CanCon programming requirements first expressed by the superseded Canadian Radio Broadcasting Commission (Bird, 1988, p. 143).

Wade Rowland (2013) describes public broadcasting as a "social invention" (p. 8) and defines it as "[a] form of electronic mass communication that is designed to serve its audience as citizens rather than as consumers; it sees its viewers and listeners as a public, a demos, rather than a market. Its purpose is to enhance public life, and enrich individual lives, rather than to serve advertisers. Its goals are cultural, rather than economic" (p. 8). Rowland's inclusion of "mass communication" and "audiences" in his definition of public broadcasting grounds his definition in the traditional, one-way and one-to-many mode of radio and television broadcasting model. This traditional mode of public broadcasting contrasts the two-way, one-to-one mode of digital media enabled by networked computing and that offers the potential for active users with agency rather than the passive audience role associated with one-to-many broadcasting.

To varying degrees, traditional radio and television public broadcasters around the world, including CBC/Radio-Canada, now exist within a public service media world involving both one-way and two-way communication. As such, public service broadcasters (PSBs) are presented with the challenge of how best to enhance their traditional broadcasting operations to serve the two-way, one-to-one, media world of the Internet and mobile wireless communications. This challenge posed by public service media (PSM) influenced CBC/Radio-Canada's response to Canada's 2011 digital television transition and the public broadcaster's ability to continue to provide access to viewers by way of its traditional OTA television service. As Gaëtan Tremblay (2016) argues, while “[d]igital networks have undoubtedly contributed to the accessibility of 
information sources", "[i]t would be presumptuous, however, to conclude that the traditional media have become useless intermediaries" (p. 197).

\section{Public Broadcasting as a Public Good/Service}

As noted by Gregory Taylor (2013), attempting to define “[e]xactly what constitutes public service or 'the public good' is a notoriously slippery concept" (p. 16). In terms of a microeconomics definition, a public good is both nonrival, meaning "its use by one person does not decrease the quantity available for someone else" and is nonexcludable, meaning that "it is impossible (or extremely costly) to prevent someone from benefiting from it” (Parkin \& Bade, 2006, p. 364). In other words, as put by Robert W. McChesney (2013), public goods are "materials or benefits that cannot be effectively excluded from use by consumers who do not 'pay' for them and can be used by one person without reducing their availability to another" (p.

51). Using OTA television as an example of a public good, a viewer of OTA television may watch as much OTA television as she wants and such an act of viewing won't restrict the ability for others to also view the same OTA television. In addition, OTA television signals radiating from an OTA television transmitter cannot be (easily) blocked from being received by all viewers located within the signal coverage area of an OTA television transmitter. As put by the $\mathrm{BBC}$,

The social value of a TV programme is therefore the aggregated valuation of all those people who might watch the programme, not just those that $d o$. The public good characteristics of broadcasting therefore have important implications for the provision of broadcasting services - restricting the viewing of programmes that, once produced, could be made available to everyone at no extra cost, leads to inefficiency and welfare losses. (BBC, 1999) 
Similarly, McChesney (2013) notes that "[o]ver-the-air broadcasting as it has been practiced is a public good" since "(w)hether three or 300 million people watch a program does not change the cost of producing that program or affect the satisfaction of the individual viewers" (2013, p. 52). While McChesney thus notes that "[t]here is no incentive to produce programs, because no one will pay you for them when they can watch them for free" (p. 52), he explains that "(m)ost nations solved this problem by using public money to create broadcasting content available to all" (p. 52). Steven Kendal Holloway (2006) offers the following differentiation between private goods provided by the market such as cable television and public goods provided by the state such as TV transmission with the following television delivery example:

Private goods and services are provided for us in the marketplace every day. The merchant selling us a newspaper, a haircut or cable TV expects to receive the going rate or payment for the good or service provided. If we refuse to pay for this type of private good, the merchant will refuse to offer it or will cut off service, as in the case of the cable company. Public goods cannot be selectively offered or denied in this manner.... Once a public good is provided, it is available to all, contributors and "free-riders" alike. Other public goods include radio and TV transmission (if unscrambled), clean air and water, and domestic law and order...We might well agree with the Statist that these public goods are in the public or national interest and should be provided. This then, is the unique and necessary role of the state (Holloway, 2006, p.10).

Subscription television services while also nonrival (at least in terms of cable television and DTH satellite delivery), are excludable, meaning that "it is possible to prevent someone from enjoying the benefits" (Parkin \& Bade, 2006, p. 364) of access to cable or satellite television - or at least for those who do not pirate cable or satellite television signals. As for Internet and mobile wireless services, they are excludable (with the exception of unencrypted Wi-Fi signals) and can be rivalrous at the point when the number of users accessing a service creates bandwidth congestion. 
In terms of whether public broadcasting is uniquely a public service, Gregory Taylor (2013) notes that although the Broadcasting Act identities Canada's entire broadcasting system as a public service and thus, "all broadcasters, public and private alike, are obligated to provide a service to Canadian citizens", the "difficulty for the CRTC is defining the parameters of this service" (p. 16). While, as Taylor (2013) notes, all licensed Canadian broadcasters are to be providing some sort of public service to Canadians, an explicit set of detailed deliverables for the radio and television services of CBC/Radio-Canada as national public broadcaster are detailed in the act (as per Section 3 (1) (l) of the Broadcasting Act). Furthermore, as put by David Taras (2015), public broadcasters such as CBC/Radio-Canada "act as a counterweight to the crushing power enjoyed by media conglomerates such as Disney, News Corporation, Bell Media, and Quebecor. Public broadcasters give citizens another place to go, another vantage point on issues" (p. 229).

\section{The Task of Serving the Imagined Community of Canada by way of public spectrum}

Benedict Anderson's (1983) concept of imagined communities is helpful when attempting to understand the aims of CBC/Radio-Canada's operations as a national public broadcaster. One such imagined community is that of a nation. Holloway (2006) notes that "[t]he term nation is used to designate a large community of people who share certain characteristics" (p. 7). According to Holloway (2006), Canada with its "large immigrant citizenr(y)" makes Canadian nationality one where citizens "share only a common territory and certain political or civic rights, duties, and symbols" (p. 7) and that "a more restrictive use of the term nation would require a shared ethnicity, implying that all members of the nation might be distant cousins, related by blood" (2006, p. 7). 
As noted by Patricia Cormack and James F. Cosgrave (2013), whereas a nation "implies a natural community of people, often based on a sense of common history, ethnicity, race, language, or culture" a state on the other hand "implies the institutions and agencies that administer and govern a particular population within a given geopolitical territory....[h]ence, some groups think of themselves as a nation, a people, in search of a state" (p. 10). In the case of Québec, the House of Commons passed a motion put forward by then Prime Minister Stephen Harper that "this House recognize that the Québécois form a nation within a united Canada" in November 2006 (Canada, 2006). Other communities of people in Canada, including but not restricted to, First Nations, Newfoundlanders, Acadians, Inuit, and Métis also regard themselves as nations residing within the state of Canada. From the earliest days of broadcasting in Canada, this reality has been a challenge for $\mathrm{CBC} /$ Radio-Canada: how to provide a national public broadcasting service to a state comprised of distinct nations. Ironically, as Michel Filion (1996a) observes, "radio and television may contribute to strengthen irreducible identities rather than developing one national cultural identity as wished by the theorists of a united and homogeneous Canada" (p. 447). As argued by Cormack and Cosgrave (2013), "CBC has the unenviable job of making the state and nation disappear into play and pleasure (p. 13)" and that "Canadians are drawn to the $\mathrm{CBC}$ in part because the $\mathrm{CBC}$ is a place where Canada gets made and remade" ( $\mathrm{p}$. 17-18).

Cormack and Cosgrave (2013) also note that "Canadians are sometimes described as a statist people - that is, as looking to and trusting state institutions, officials, and policies to manage problems of all sorts. In other words, they find pleasure and identity in being administered through the state" (p. 10-11). Furthermore, Cormack and Cosgrave (2013) note that "Richard Gywn (1995) has gone as far as to say that "rather than a nation-state...we are 
really a state-nation... '...(i)n other words, in Canada the state seems to have preceded and

induced the nation (p. 11).

Expanding on the work of Anderson, Marusya Bociurkiw (2011) notes that television's

(traditional) appointment-viewing broadcast structure is useful when striving to arouse

nationalism,

[Chris Barker] makes a distinction between the nation-state as a political apparatus concerned with the administration of space or territory and, following Anderson, nationalism as the imaginary identification with that space: "The nation-state as a political apparatus and symbolic form has a temporal dimension in that political structures endure and change, while the symbolic and discursive dimensions of national identity often narrate and create the idea of origins, continuity and tradition" (64-65). In a similar vein, Kaja Silverman writes that a material relation to the nation-state (citizenship rights, health care, geographical relation) is invested in an imaginary relation, or what I would call nationalism. This relation is, she argues, underpinned by affect: it is a hope, or a nostalgia, rather than a reality (22). (p. 39)

Anderson's notion of national time is similarly applicable to theories of simultaneity with regard to television. Television, as a time-based medium with daily, weekly, and yearly programming schedules, is particularly suited to the creation of national time, providing an awareness of people across a geographical space witnessing an event together through television. The faraway is made proximate, but this shift does not necessarily mean that we care more for this faraway world. Instead, the faraway is associated with anxiety, trouble, and disaster, and television works to reinforce the distance (and "our" proximity within the nation) even as it brings the faraway into the home. (p. 41)

Insight into the nationalistic "hope" that CBC/Radio-Canada's services strive to stimulate is noted by David Taras (1999) who cites Francophone journalist André Laurendeau who argued in 1949 that the Massey Commission's efforts to thwart the perceived threat of the Americanization of the Dominion of Canada was to task the Corporation to sell "the myth" of "Canadian national culture...a phantom, the shadow of a shadow" (p. 121). For Laurendeau and 
others, Canadian national culture is a simulacrum - a copy without an original (Baudrillard, 1994) .

\section{The Public Interest vs. Consumer Choice}

The elusive concept of the public interest has been cited in reference to Canadian broadcasting dating from the Aird commission of 1928-1929 to the CRTC's Let's Talk TV initiative of 2013-2015. Such mentions of the public interest rarely also include a definition of what the public interest might entail. Gregory Taylor (2013) notes that "[a] 2004 Canadian government external advisory committee on regulation....found that there is no shared definition of the public interest among government departments"' (p. 16). While governments might struggle at arriving at a collective shared definition of the public interest, Trudy Govier (2006) argues that they are nonetheless uniquely well suited at serving it,

What is special about government is that it, and it alone, is charged with serving and protecting the public interest. Charities, individuals, and not-for-profit groups may seek to further the public interest, but only government has the promotion of public well-being as its official task. Government has the constitutional ability to pass laws and monitor and enforce compliance with those laws... The role of government is to serve and protect the public interest. The role of business is to make money. (p. 172-173).

As noted by Vincent Mosco (2009), the public interest is "a term with roots in the law governing regulation of the communication industries" (p. 152). Mosco (2009) notes that the concept of the public interest has been criticized for its "ambiguity, particularly when set against the seemingly clear test of the marketplace" (p. 152). However, Mosco (2009) notes that the "public interest idea nevertheless survives in law, though the process of commodification has weakened its standing. It also survives in research as an extension of the public sphere notion to refer to those interests that transcend commercial gain and consumerism” (p. 152). For Mosco (2009), the idea of the public sphere as popularized by Jürgen Habermas is defined as: 
[a] set of social processes that carry out democracy, namely advancing equality and the fullest possible participation in the complete range of economic, political, social and cultural decision-making. These processes are distinct from those centered in private life, which promote interpersonal intimacy, and from those of the marketplace, which advance the creation of exchange and surplus value (p. 152).

In terms of links between the public sphere and public media, Mosco (2009) notes:

What we call the public media is public, not because it occupies a separate space, relatively free from market considerations, but because it is constituted out of a particular patterning of processes that privilege the democratic over commodification. To the extent that it does not, the expression public media diminishes in value (p. 154).

Furthermore, as noted by David Skinner (2008), “across the last 15 to 20 years, market imperatives have increasingly gained hold of the system and the public interest has increasingly been defined in terms of consumer choice" (p. 4). One example of such an approach to serving the public interest is, as previously noted, the CRTC's "pick and pay and small packages" BDU television regulation introduced in March 2016 and scheduled to come into full effect by December 1, 2016. These television delivery regulations are purportedly aimed at serving the public interest by offering Canadian BDU television subscribers more choice in terms of what television channels are included in their monthly television subscription packages and more affordable access to television by way of BDUs.

In light of the amount of debate over how exactly to define the public interest, the best definition of the public interest to date might be a definition offered by Marc Raboy (1990) which states that "if there is ' $a$ ' public interest, it is in seeking to achieve a context for the just and equitable coexistence of different, distinct, and often conflicting publics" (p. 356). Serving such a definition of the public interest is a challenge for CBC/Radio-Canada, according to Raboy (1990), since it has been mandated to serve the singular public interest known as the Canadian national interest. As Raboy (1990) argues repeatedly in his work, since CBC/Radio-Canada 
finds the public interest and the national interest as "defined as meaning the same thing" $(1990$, p. 58), and that the public interest has historically been subservient to CBC/Radio-Canada's serving of the national interest - particularly during periods of national crisis. At the same time, Raboy (1990) notes that, "[t]he power and importance of "private" broadcasters in Canada have grown steadily and without interruption, but the role of the "public" element of the system has ebbed and flowed" (p. 9). With Canada's "mixed" broadcast system of public and private interests, what Canada ended up with according to Raboy was a broadcast system "based on the combined self-interests of governments and broadcasting institutions" and a system "which did not necessarily correspond to anything a public would identify as in its own interest" (1990. p. 9).

\section{Disintermediation: Threat or Opportunity for Public Service Media?}

In terms of the success that BDUs have had with TV Everywhere services that require Internet users to log in using a paid BDU television subscription account in order to watch programming licensed by a BDU online within a particular television territory, Michael Strangelove (2015) notes that as of 2014, "only 21 per cent of pay-TV subscribers used TV Everywhere services at least once a month" (p. 174). Strangelove (2015) suggests that TV Everywhere is currently no match to pirated television available through the Internet and that in order to make TV Everywhere work the industry relies on levels of "collusion" that he finds legally suspect (p. 175). While vertically integrated media companies may control the production and distribution of television, and benefit from protections provided by copyright legislation, Strangelove (2015) notes that "the Internet has thus far defied attempts to impose a territorialisation of scarcity" (p. 184) since online piracy provides alternative access to programming (once such content is first made available publicly) even when the media industry 
attempts to make its online programming scarce through the use of walled media gardens requiring a subscription to access.

Insight offered by Strangelove (2015) helps to demystify the hype and efficiencies of BDU television delivery as argued by $\mathrm{CBC} /$ Radio-Canada. Not only do pay-walled barriers to television act as barriers to access to public television programming but they also aren't proving to be very popular with subscribers either. Importantly, Strangelove (2015) notes that vertical integration of the television industry and the efforts put behind TV Everywhere reflect responses by the industry to the disintermediation of the North American television-system previously experienced at the end of the twentieth-century by the music industry.

Disintermediation is the process by which the producers of media such as television "are bypassing the traditional middlemen and connecting directly with consumers" (Gasher, Skinner, Lorimer, 2012, p. 177). In the case of television delivery in Canada, the 'traditional middlemen' are BDUs. At the same time, disintermediation of television delivery "face(s) counter-forces of remediation" (Strangelove, 2015, p. 175) which entails, for example, Canadian BDUs attempting to incorporate Internet television delivery services into their operations through over-the-top (OTT) television subscription services such as Bell's CraveTV and Rogers/Shaw's failed Shomi OTT service. However, Strangelove (2015) argues that "the television industry's adaptive measures may not be enough to forestall the disintermediating effects of the Internet" (p. 176). Strangelove (2015) also notes that it does not really help that cable television and telecommunications companies like Rogers and Bell are not exactly well-loved and "cannot count on consumer loyalty to keep its customers...creat[ing] conditions that compel many customers to seek out disintermediating agents" (p. 180). 
While Strangelove's analysis of television does not make a distinction between OTA television broadcasters and BDU television providers, presumably due to the fact that both have traditionally offered linear, appointment-style television viewing experiences, this dissertation does include digital OTA television broadcasters as disintermediating agents. Of the digital OTA television broadcasters licensed to operate in Canada, CBC/Radio-Canada as national public broadcaster, along with provincial educational broadcasters such as TVO and TéléQuebéc, represent the most potentially potent disintermediating OTA agents since their mandates are not restrained in the same way as private, for-profit OTA television broadcasters. If Canadian television-viewing households are seeking access to $\mathrm{CBC} /$ Radio-Canada television programming and they don't want, or are unable, to subscribe to a BDU, CBC/Radio-Canada is able to deliver its programming directly to citizens through a combination of digital OTA television transmitters and via the Internet. CBC/Radio-Canada likely does not have a TV Everywhere strategy because it does not need one. Disintermediation as it applies to BDUs is not the same threat for $\mathrm{CBC} /$ Radio-Canada. Instead, disintermediation presents an opportunity for $\mathrm{CBC} /$ Radio-Canada to improve access to its services. However, to date, $\mathrm{CBC} /$ Radio-Canada's approach to the digital delivery of its television services has been focused on achieving cost efficiencies through the degrading of its ability to reach Canadians over-the-air combined with continued reliance upon a BDU delivery model at a time when BDUs themselves are erecting additional barriers to access as a response to the threat of disintermediation.

$\mathrm{CBC} /$ Radio-Canada, and $\mathrm{CBC}$ Television in particular, have largely retained appointment-viewing television window schedules similar to those preferred by verticallyintegrated private television broadcasters in Canada that are fighting disintermediation. That $\mathrm{CBC} /$ Radio-Canada is being pulled in two television delivery directions is not surprising. One 
television delivery direction for the public broadcaster adheres to the direction of traditional appointment-viewing that aims to create both programming scarcity and generate related advertising revenues. The other television delivery direction adheres instead to a process of disintermediation that allows $\mathrm{CBC} /$ Radio-Canada to skip BDUs entirely and for it to deliver its television programming (both live and in archive form) directly to viewers by way of the Internet. These opposing directional pulls reflect the public broadcaster's hybrid funding model that relies on both public funding (where disintermediation is not a threat) and private advertising dollars (where disintermediation is a threat).

As this chapter has outlined, there is little consensus about how exactly to define the public interest in terms of the regulation of Canada's television system. However, there does appear to be some agreement that when it comes to public broadcasting, serving the public interest is not limited to the achievement of cost-cutting efficiencies by broadcasters. While private OTA television audience shares in Canada "dropped from 45.3 per cent in 1993 to 33.3 per cent in 2001 to just 22 per cent in 2008-2009" (Taras, 2015, p. 17-18), a shift that has significantly cut into the profits previously enjoyed by private OTA television broadcasters and prompted corresponding efforts by private broadcasters (many of which are now owned by BDUs) to realize greater operational efficiencies through station closures and layoffs. The public broadcasting operations of $\mathrm{CBC} /$ Radio-Canada in contrast are not limited in scope to operational cost-cutting. As per Anne MacLennan's (2011) critique of the history of the public broadcaster's operations in Canada's North, while CBC/Radio-Canada "as a Crown Corporation, has always been expected to operate in the public interest and at arm's length from the government" its public broadcasting mandate also "requires it to provide services that may on occasion be at odds with the reality of broadcasting" (p. 64). 


\section{User agency and Public Service Media (PSM)}

Continuing the previous section's discussion of how disintermediation provides an opportunity for $\mathrm{CBC} /$ Radio-Canada as a public broadcaster more so than it poses a threat, in terms of the challenge of a public broadcaster navigating the shift from PSB to PSM, Ike Picone, Koen Willaert, and Karen Donders (2013) note that "the increasing possibilities for involving citizens in interactive modes of media consumption are embraced by scholars advocating for a social responsibility perspective on public service broadcasting” (p. 55). Picone, Willaert, \& Donders (2013) note that public broadcasters typically focus on low level "modes of interaction, for example a poll in the context of a specific programme" when approaching PSM and that there "are but a few examples of a more in-depth interaction that is aimed at fostering a genuine sense of dialogue between public broadcasters and media users and letting viewers impact the content, flow or format of the programme" (p. 56).

In terms of CBC/Radio-Canada's own response to this shift from PSB to PSM, Philip Savage (2010) asks how the public broadcaster is "reflecting Canadian societal transformation while changing institutionally even as the technological, demographic, political and economic structures - the nation's prosaic housekeeping - change and Public Service Broadcasting (PSB) becomes Public Service Media (PSM)" (p. 273). In terms of the role of PSB, Savage notes "PSB is seen as a central mechanism for the information and cultural exchange key to a democracy, which according to Jürgen Habermas, relies on a vibrant public sphere for discussion among the broadest civil society (Habermas, 1962)” (2010, p. 273-274). Citing the work of Vincent Mosco, Savage identifies "the role of PSB as an alternative to market-driven and increasingly consolidated commercial media which commodify the audience role rather than directly enhance citizen democratic potential (Mosco, 1996, 17-8)" (Savage, 2010, p. 274). Thus, with regards to 
the evaluation of CBC/Radio-Canada's television services, Savage (2010) argues that "the measures of success CBC-TV uses encompass a narrow view of public involvement relative to that of CBC-Radio. TV largely uses commercial, ratings-based language of average minute audiences (AMAs) and Prime Time Share" (p. 277-278).

Savage notes that the "(d)igital extension of existing broadcasting content via the internet (though not always new content on new media) is the current CBC mantra" and that "few at CBC.ca are willing to make the leap - at this point - to new media potential for cultural democracy strategies often associated with Web 2.0" (2010, p. 280). Savage also notes that for 2007-2008, “CBC declared modest, 'housekeeping'-oriented goals for its digital platforms, that is, to provide a more efficient dissemination of radio and TV content" (2010, p. 280). In its 2008 submission to a 2009 CRTC hearing on Canadian broadcasting in new media, Savage notes that CBC/Radio-Canada pointed to CBC.ca traffic as a successful example of its digital strategy but that its submission made "limited reference to Web 2.0 potential" (2010, p. 280).

Despite Mark Armstrong and Helen Weeds (2007)'s gloomy prediction that “public service broadcasting will indeed soon be dead" based on their argument that within the U.K. digital media environment "the 'market failure' rationale [for public broadcasting is] largely removed" and the "growing difficulties in getting people to watch "what we want them to watch"' (p.35) in the digital media era, Picone, Willaert, \& Donders (2013) note that others are instead calling for "an extended public service media project, allowing all citizens to participate, interact, enter into a dialogue, etc., regardless of their market appeal to advertisers (Barnett 2002)" (p. 55). 


\section{Efficiency and Public Broadcasting in the Digital Age}

Notions of television delivery efficiency in the digital age are tied to the manner in which efficiency is being imagined and gauged by broadcasters. As noted earlier, the word "efficient" was only added to $\mathrm{CBC} /$ Radio-Canada's radio and television delivery mandate as of the Broadcasting Act of 1991. This section reveals how the assessment of radio and television delivery efficiency is not a homogenous calculation, particularly for a public broadcaster like CBC/Radio-Canada. The three types of public programming delivery efficiency that will be explored in this section are spectral efficiency, economic efficiency, and allocative efficiency. This section also discusses how notions of efficiency are linked to CBC/Radio-Canada's ability to provide citizen access to its television programming in the digital age.

While economic efficiency is certainly relevant to the television delivery operations of any television broadcaster, this section reveals that when imagining the digital provision of a public service, specifically a public television service provided by a Crown Corporation, notions of delivery efficiency are never solely limited to considerations of cost minimization. Such a nuanced approach to understanding digital television delivery efficiency was largely missing from Canada's overall approach to its digital television transition. As Gregory Taylor (2009) remarked with regards to the anticipated efficiencies to be achieved by Canada's digital television transition when compared to the digital television transitions conducted in other countries, "[e]fficiency, the common refrain of neoliberal advocates, has in [Canada's] case proven a hollow slogan" (p. 259). 
Prior to discussing the various aspects to public television delivery efficiency in the digital age, this dissertation echoes Janice Gross Stein's (2001) assertion that efficiency must always be understood as a means to an end and not an end unto itself. As put by Stein (2001),

When we define efficiency as an end, divorced from its larger purpose, it becomes nothing less than a cult (p.3-4)....Efficiency is not an end but a means to achieve valued ends. It is not a goal but an instrument to achieve other goals. It's not a value but a way of achieving other values. (p. 6)

\section{Spectral Efficiency}

CBC/Radio-Canada's analogue OTA television transmitters (like all analogue OTA television transmitters) were spectrum hogs and comparatively inefficient in terms of their use of publicly owned spectrum. Allocating $6 \mathrm{MHz}$ of spectrum, as is done in North America, to send a single analogue OTA television signal is an inefficient use of spectrum when compared to digital OTA television broadcasting which allows for the same $6 \mathrm{MHz}$ of spectrum to be used to deliver a variety of broadcasting and communications services. When using digital OTA television broadcasting technology, such as the North American ATSC digital television broadcast standard, $6 \mathrm{MHz}$ of spectrum provides a television broadcaster "the flexibility to operate an HDTV program with some ancillary program services, such as mobile TV, or two standarddigital TV (SDTV) programs or other combinations, including two programs each from different broadcaster entities" (Industry Canada, 2012, p. 85).

The digital OTA television broadcasting flexibility described above is referred to as multiplexing. Multiplexing allows digitized packets of information, or bits, (video, audio, data) to be delivered in the same "transport stream" (or broadcast), in a serial fashion (Pizzi \& Jones, 2014, p. 258). Thanks to multiplexing, a digital OTA television broadcaster has the option of 
adding different streams of data (such as, a second television channel) into the multiplex and broadcasting it OTA within the same $6 \mathrm{MHz}$ band of spectrum - referred to as multicasting (Pizzi \& Jones, 2014, p. 258).

The CRTC encouraged the use of such multiplexing/multicasting by all OTA television broadcasters leading up to Canada's digital television transition on the grounds that it would assist with viewer access, stating "(b)roadcasters should continue to explore opportunities such as multiplexing to ensure that Canadians continue to have access to free (over-the-air) conventional television services" (CRTC, 2010a). The CRTC reiterated its support for OTA multiplexing as part of CBC/Radio-Canada's most recent licence renewal (CRTC, 2013). While $\mathrm{CBC} /$ Radio-Canada has experimented with multiplexing in the past, mainly with regards to limited ATSC Mobile DTV testing (Nolet, 2012), the public broadcaster has not used multiplexing on any regular basis. Rather, as part of CBC/Radio-Canada's request to the CRTC in 2012 to shut down its analogue OTA television transmitters, the public broadcaster summarized its lack of multiplexing as follows:

Thus far, the test results indicate that although a single ATSC channel is capable of broadcasting two HD signals, this cannot be done without signal degradation which is manifested in a less clear picture. CBC/Radio-Canada has not gone to the expense and dislocation of converting its broadcasting network to digital in order to degrade the quality of its HD signal and has no intention of doing so....Therefore, while digital multiplexing may hold promise in the future, it is not a viable option for the $\mathrm{CBC}$ to pursue at the present time.

(CBC/Radio-Canada, 2012c)

In terms of CBC/Radio-Canada's use of digital OTA television broadcasting as compared to its use of analogue OTA television broadcasting, $\mathrm{CBC} /$ Radio-Canada has declined to fully leverage the spectral efficiency of multiplexing that the ATSC standard allows, based on concerns related to picture quality. Contrary to $\mathrm{CBC}$ /Radio-Canada's concerns, improved 
MPEG-2 compression technology allows for two, 720p HD feeds to be sent within the same 6 MHz channel operating at 19.39 Mbps since each 720p HD signal can be broadcast using 9 Mbps (Nordahl, 2011). Use of such MPEG-2 compression would help address CBC/RadioCanada's concerns about the quality of its digital OTA television signals being affected by multicasting. Since both CBC Television and Télévision de Radio-Canada are already broadcasting OTA at 720p, use of current MPEG-2 compression technology would allow the public broadcaster to continue to deliver an HD signal to Canadian households in addition to one multiplexed OTA subchannel (at a minimum) from each of its 27 digital OTA television transmitters.

A compelling example of how multiplexing would allow $\mathrm{CBC} /$ Radio-Canada to maximize the spectral efficiencies afforded by the ATSC standard would be for the public broadcaster to include a subchannel of Télévision de Radio-Canada as part of each CBC Television digital OTA broadcast in television markets where it no longer has a Radio-Canada television transmitter. Conversely, use of multiplexing by the public broadcaster would allow for a subchannel of CBC Television to be provided as part of each Télévision de Radio-Canada digital OTA broadcast in markets where it no longer has a CBC Television transmitter. Such multiplexing would permit the public broadcaster to deliver OTA broadcasts in both English and French in television markets where it currently only broadcasts in one of Canada's official languages. Furthermore, use of multiplexing could also allow CBC Television and Télévision de Radio-Canada to include subchannel(s) of CBC/Radio-Canada radio broadcasts with their television broadcasts. In terms of markets where $\mathrm{CBC} /$ Radio-Canada has no digital OTA television transmitters, it could make meaningful attempts to broker agreements with provincial educational broadcasters and private Canadian broadcasters to have a subchannel of CBC 
Television and/or Télévision de Radio-Canada by way of broadcasters with digital OTA television transmitters in markets where $\mathrm{CBC} /$ Radio-Canada has none.

Since CBC/Radio-Canada has, to date, declined to leverage the multiplexing of its television broadcasts from either its own network of 27 OTA digital transmitters or from the digital OTA television transmitters of other Canadian broadcasters, $\mathrm{CBC}$ /Radio-Canada has yet to fully harness the achievable spectral efficiencies provided for by the switch from the analogue NTSC television standard to the digital ATSC television standard with the same swath of $6 \mathrm{MHz}$ allocated to each transmitter.

\section{Economic efficiency}

Economic efficiency is a notion of efficiency widely understood within capitalist markets. Microeconomics defines economic efficiency as "a situation that occurs when the firm produces a given output at the least cost" (Parkin \& Bade, 2006, p. G-2). Such a definition of efficiency is central to the operations of for-profit businesses. By producing a good or service at the least cost, a firm hopes to maximize profits. In a scenario where the cost for a for-profit firm to produce a product or service is consistently greater than the firm's output, such a firm would be deemed to be utterly economically inefficient since it would be taking a loss on the whole exercise. The allure of economic efficiency in Canada also extends beyond the field of business to include, for example, the late Rob Ford's successful run for Mayor of Toronto in 2010 aided by his use of the slogans "respect for taxpayers" and "end the gravy train" that suggested Ford would bring the merits of economic efficiency to local government. 
In terms of how notions of economic efficiency relate to the delivery of $\mathrm{CBC} /$ Radio-

Canada's television services, Broadcaster Magazine couched CBC/Radio-Canada's response

to Canada's digital television transition as follows,

The $\mathrm{CBC}$ argued that the public interest was better served by using the cost-savings associated with eliminating its obsolete analog network and any proceeds from the disposition of the associated land, equipment, towers and buildings to invest in programming services whose budgets were also threatened by the cuts to its funding. (2012, n.p.)

As quoted on the first page of this dissertation, CBC/Radio-Canada's website reported to Canadians at the time that its (by then) remaining network of 607 analogue OTA television retransmitters were only serving $1.7 \%$ of the Canadian population and that the continued operation of the analogue retransmitters was costing the Crown corporation $\$ 10$ million per year (CBC/Radio-Canada, 2012a). When $\mathrm{CBC/Radio-Canada}$ discusses serving the public interest by way of television delivery efficiency, it has been inclined to focus on providing public service for the least cost. $\mathrm{CBC} /$ Radio-Canada claimed that the cost savings to be achieved from its approach to Canada's digital television transition would result in more funds being directed toward the creation of television programming by the public broadcaster. Such an approach to economic efficiency was summarized by the CRTC in its decision approving $\mathrm{CBC} /$ RadioCanada's requested change to its television broadcasting licences (CRTC, 2012c) as follows:

... CBC noted its financial situation, the relatively low number of households relying on over-the-air transmission for reception of its service and the availability of viable alternatives for receiving its television signal. The $\mathrm{CBC}$ further noted that it had an obligation under the Broadcasting Act (the Act) to manage its resources as efficiently and effectively as possible to further its mandate. It described the difficulties of acquiring equipment and parts that were obsolescent and increasingly unavailable. The $\mathrm{CBC}$ also indicated that shutting down the analog television network would save a minimum of $\$ 10$ million a year in operating costs and would allow it to generate revenues through the sale of assets.

Given all of the preceding, the CBC argued that the public interest was better served by using the cost-savings associated with eliminating its obsolete analog 
network and any proceeds from the disposition of the associated land, equipment, towers and buildings to invest in programming services whose budgets were also threatened by the cuts to its funding....

The Commission also notes that licences, such as those held by the $\mathrm{CBC}$, are authorizations to broadcast, not an obligation to do so. In other words, while the Commission has the discretion to refuse to revoke broadcasting licences, even on application from a licensee, it cannot direct the $\mathrm{CBC}$ or any other broadcaster to continue to operate its stations and transmitters. (CRTC, 2012c)

Such a rationale forwarded by $\mathrm{CBC} /$ Radio-Canada regarding the merits of achieving economic efficiency has also been extended to its remaining network of digital OTA television transmitters. As recently pitched by CBC/Radio-Canada to the CRTC as part of its 2014 Let's

Talk $T V$ submission, the public broadcaster noted that:

Given the costs of transmission and the availability and prevalence of BDU delivery, OTA transmission is no longer a cost efficient way of delivering programming in many locations and should no longer be a pre-requisite for the general licensed operation of conventional television stations in Canada. As the Commission has noted in BNC CRTC 2014-190, OTA viewing is now very low: in fact nationally it is only 5\%, according to the latest Media Technology Monitor (MTM, Spring 2014). This is therefore neither an efficient nor a popular delivery mechanism. Yet delivery by over-the-air technology continues to define the licensing of conventional television broadcasters, and to define, through the operation of the Copyright Act, the financing that is available to these undertakings.

A far more efficient delivery mechanism (i.e. direct feeds to BDUs) is widely available and in use in practically all markets within Canada.

Given these realities, the Corporation submits that the current licensing regime for conventional television should be modified to permit conventional television broadcasters to operate without relying on OTA transmission, if they so choose. Specifically, a licensed conventional television service would be subject to the same regulatory obligations and serve the same geographic areas as are currently applicable but would not be required to operate an OTA transmitter in order to retain its licence [meaning, a broadcaster would be able to retain a television broadcasting licence without actually having to operate a transmitter in a given television market]. Any applicants for a new licence to serve a market would be required to define a proposed geographic service area (e.g. a municipal boundary) which would be subject to scrutiny by the Commission.

(CBC/Radio-Canada, 2014b, p. 9) 
As will be discussed next, the unique nature of $\mathrm{CBC} /$ Radio-Canada's television operations calls for the public broadcaster to also consider a third notion of efficiency, allocative efficiency, when considering viewer access to its television programming in the digital era.

\section{Allocative efficiency}

Whereas economic efficiency is concerned with the "production of goods and services... at the lowest possible cost" (infoDev, 2016, p. 112), allocative efficiency instead strives to ensure that "an optimal mix of goods and services is produced which maximizes consumer welfare" (infoDev, 2016, p. 112). As noted by Mark Armstrong and Helen Weeds (2007), "[a]llocative efficiency dictates that a programme should be viewed by all individuals whose consumption generates positive surplus" (p. 87), meaning everyone who values particular content should receive it. This dissertation argues that when discussing the aim of achieving access to television programming, particularly to public television programming, attention to allocative efficiency is equal in importance to attention paid to spectral efficiency and economic efficiency.

The ability of an OTA television broadcaster to achieve allocative efficiency is tied to infrastructure, as Armstrong \& Weeds (2007) outline below:

Once infrastructure is in place, costs do not increase significantly with the number of programmes delivered, consisting only of the power required to broadcast the signal. Moreover, once broadcast, a signal can be picked up by anyone with the necessary receiving equipment: there is no incremental cost of transmitting a programme to an additional viewer. The viewer makes an initial investment in receiving equipment, after which no additional cost is incurred in receiving further broadcasts. (p. 85)

Once infrastructure is built, Armstrong \& Weeds (2007) note that a television broadcaster can then rely on its OTA transmitters to assist it in achieving allocative efficiency:

[t]he broadcasting industry is characterised by substantial fixed costs while marginal, perviewer costs are negligible. Programme production costs are independent of the number of viewers and, once transmission and reception capacity are in place, the marginal cost of 
transmitting the programme to an additional viewer is zero...

Since an existing programme can be supplied to an additional viewer at no incremental cost, this requires the programme to be provided to all viewers with a positive valuation of it, however small. Such an outcome can be achieved by setting the price of viewing equal to marginal cost - i.e. at zero. At this price all individuals with a positive valuation view the programme and consumption is at the efficient level. (Armstrong \& Weeds, 2007, p.87-88)

In terms of how the costs of running a television broadcasting service, including but not limited to the operation and maintenance of OTA television transmitters, are to be paid for, "[a]ppeals to allocative efficiency are often used to support funding in the form of a licence fee, or out of the public purse" (Armstrong \& Weeds, 2007, p. 88). However, Armstrong \& Weeds (2007) note that while this approach works well for existing television programming, “(m)arginal cost pricing (even with a subsidy to cover fixed costs) gives poor incentives for high quality provision, innovation and cost efficiency. Balancing these arguments, some means of revenue generation must be found that minimises allocative inefficiency while also allowing costs to be covered and providing good incentives to producers" (p. 88).

While a strong argument can be made that the annual federal allocation of funds directed to $\mathrm{CBC} /$ Radio-Canada (roughly $\$ 1$ billion per year which typically only covers two thirds of its annual budget, at best) are insufficient to cover all of the costs associated with the operation of a national public broadcasting radio and television service in French, English, and a number of Indigenous languages (such that all this service might be offered to the Canadian public at a price that is equal to marginal cost), if $\mathrm{CBC} /$ Radio-Canada were to cease to operate any OTA television transmitters at all it would have difficulty achieving allocative efficiency. Under such a scenario, CBC/Radio-Canada would need to find some other way to provide all households that have a positive evaluation of its programming with television programming access at a price 
equal to marginal cost. Currently, only one other service in Canada provides such access, that of Shaw Direct's LTSS satellite DTH service (as detailed in Chapter 2), and it is possible that the LTSS may end after August, 31, 2019 if the CRTC does not require the LTSS to continue. If a future Canadian television delivery scenario were to develop such that $\mathrm{CBC} /$ Radio-Canada is no longer operating any OTA television transmitters and where Shaw ceases to support its LTSS program, CBC/Radio-Canada will have fully converted the costs previously associated with Canadian households being able to receive $\mathrm{CBC} /$ Radio-Canada television programming OTA into an external cost, thus turning the cost of the provision of access to CBC/Radio-Canada television programming into a cost "not borne by the producer but borne by other people" (Parkin \& Bade, 2006 p. 349).

This chapter provided a review of existing literature critical of digital convergence and the equitable provision of public service media to citizens in the twenty-first century. By accounting for various scholarly definitions of concepts such as the public interest, consumer choice, user-agency, and efficiency, a greater understanding of the provision of access to public service media in a post-analogue environment can be attempted. Such a literature review also allows for an informed analysis of this dissertation's primary research interviews related to CBC/Radio-Canada operational response to Canada's 2011 digital television transition. The next chapter provides insight into preparation and execution of the primary research interviews conducted for this dissertation in addition to the methodological approach. 


\section{Chapter 5: Methodology}

With CBC/Radio-Canada's 2012 operational response to Canada's 2011 digital television transition deadline serving as a case study, the research participants interviewed for this dissertation add to the dominant discourse of what has already been said by the likes of the Canadian government and $\mathrm{CBC}$ /Radio-Canada's Corporate Communications department about the provision of access to the public broadcaster's television programming following Canada's digital television transition.

As noted by Michel Foucault (1972) "[t]he archive is first the law of what can be said, the system that governs the appearance of statements as unique events" (p. 145). The CBC/RadioCanada OTA analogue television-viewing households and members of $\mathrm{CBC} /$ Radio-Canada Management interviewed for this dissertation emerge as "fragments" (Foucault, 1972, p. 147) of the $\mathrm{CBC} /$ Radio-Canada digital television transition archive and provide insight into the laws of how CBC/Radio-Canada's television transition is discussed. As noted by Marusya Bociurkiw (2011), "[f]or Foucault, the archive is synonymous with the rules of discourse" and "the rules of the archive, he claims, govern how we speak" (p. 36). OTA CBC/Radio-Canada televisionviewing households and members of $\mathrm{CBC} /$ Radio-Canada Management are the focus of this dissertation due to the insight that they offer into the provision of access to $\mathrm{CBC} /$ Radio-Canada television programming and the "discontinuities" (Foucault, 1972, p. 147) that their experiences offer with regards to the archive of CBC/Radio-Canada's response to Canada's digital television transition deadline.

Canadian household viewing of $\mathrm{CBC} /$ Radio-Canada television programming is the focus of this dissertation, rather than $\mathrm{CBC} /$ Radio-Canada television viewing at schools, pubs, places of worship, places of employment, airports, viewing from inside moving vehicles, viewing by 
Canada's homeless, or viewing by Canadians within the correctional system, since the regulation of Canadian's television broadcasting system centres on the household viewing metric. In addition, the household viewing metric factors in the possibility of there being more than one person, and more than one $\mathrm{CBC} /$ Radio-Canada television viewer, residing in the same Canadian dwelling.

This dissertation could have alternatively sought to interview OTA television-viewing households that couldn't have cared less about their level of access to CBC/Radio-Canada television programming or households that never watched $\mathrm{CBC} /$ Radio-Canada television programming to begin with. While such interviews may have yielded equally valuable insight into access to television provided by $\mathrm{CBC} /$ Radio-Canada, the rationale for interviewing $\mathrm{CBC} /$ Radio-Canada television viewing households that did care about a loss of access to the public broadcaster was that such households might be able to advise on how best to enhance access to the public broadcaster's television programming in the digital age. In addition, households that previously viewed $\mathrm{CBC} /$ Radio-Canada television in the analogue OTA era were able to report on how the analogue OTA television service had been providing the household with access to the public broadcaster since many had been watching CBC/Radio-Canada OTA for decades. This dissertation is focussed on the delivery of $\mathrm{CBC} /$ Radio-Canada television programming to households that yield a positive surplus when they are able to access the public broadcaster's television programming.

With regards to this dissertation's research interviews conducted with members of $\mathrm{CBC} /$ Radio-Canada Management, while an aim of conducting research interviews with more than five members of $\mathrm{CBC} /$ Radio-Canada Management was initially desired, a member of $\mathrm{CBC} /$ Radio-Canada Management advised in an e-mail that "we believe that the questions you 
pose have already been sufficiently dealt with by the other executives you have interviewed". The Government of Canada, Canadian Heritage, Industry Canada, Shaw Communications, and TVO either did not respond, or declined requests to be interviewed for this dissertation.

While the semi-structured interviews conducted for this dissertation were focused on the topic of CBC/Radio-Canada television access, the questions posed to CBC/Radio-Canada OTA television viewers were largely related to television reception and the questions posed to a nonrandom purposive sample of CBC/Radio-Canada Management were largely related to television delivery. The methodological rationale for such an approach was to collect qualitative insight from both viewers and management into their experiences related to navigating $\mathrm{CBC} /$ RadioCanada's response to Canada's digital television transition. Research interview questions posed to both groups were used to kickstart discussion of CBC/Radio-Canada television access with the aim and expectation that such discussion would expand, reflecting the unique television delivery perspective and experiences of each research participant.

CBC/Radio-Canada's approach to Canada's digital television transition not only serves as a case study for this dissertation but also its qualitative "unit of analysis" (Miles, Huberman \& Saldana, 2014, p. 28). In terms of data collection, the task of locating analogue OTA CBC/Radio-Canada television-viewing households was difficult, in part due to the fact that they represented a minority of Canadian television viewers. This was known going into the dissertation's research phase since OTA television viewers have been the minority of televisionviewers in Canada since 1978 (Armstrong, 2010, p. 44). The aim of interviewing such households was that they would be able to offer insight into the public broadcaster's ability to provide access to households that were not captured by the BDU, ISP, or mobile wireless television delivery models. 
With regards to locating analogue OTA CBC/Radio-Canada television-viewing households to interview, a combination of "theoretically driven", "prespecified" and "emerges as you go“" approaches were used (Miles, Huberman \& Saldana, 2014, p. 33). Printed calls for research participant posters were placed in public spaces in rural Ontario, small town newspapers were contacted, a WordPress blog was used, social media such as Facebook and Twitter were used, and a CBC Radio One interview broadcast in St. John's, Newfoundland was also used to try to contact eligible research participants to mitigate any bias inherent in the non-random purposive sample.

While a few responses were received via handwritten letters mailed by way of Canada Post, e-mails, and Twitter Direct Messages, the most successful attempt at reaching analogue OTA CBC/Radio-Canada television viewers was care of a not-for-profit organization named Friends of Canadian Broadcasting that is "not affiliated with any broadcaster or political party" (FCB, n.d.). Ian Morrison, spokesperson for Friends of Canadian Broadcasting (FCB), agreed in 2012 to "e-blast" this dissertation's call for research participants to FCB's membership. As part of the call for research participants, a $\$ 5$ Tim Hortons gift card was offered in return for each eligible household interview conducted (at the expense of this dissertation's author). More than 200 participants responded to the two FCB e-blasts sent to its membership (one in English and one in French) between July and August 2012. Morrison advised that he directed the e-blasts at rural portions of the group's membership and as such the research sampling for this dissertation was largely rural English and French speaking television-viewing households and thus focused "on people with similar demographic or social characteristics" (Miles, Huberman \& Saldana, 2014, p. 33). This approach to soliciting for research participants turned out to be fruitful since all but two of CBC/Radio-Canada's digital OTA television transmitters were restricted to 
mandatory digital television markets as defined by the CRTC and thus $\mathrm{CBC} /$ Radio-Canada television viewers in 18 urban mandatory digital television markets received at least one CBC/Radio-Canada OTA digital television transmitter (CBC Television and/or Télévision de Radio-Canada) as of end of July 2012.

On the matter of anticipated research findings from respondents to the two e-blasts sent to members of Friends of Canadian Broadcasting (FCB), while it may be of little surprise that a declared friend of Canadian broadcasting would be concerned more generally about the state of Canadian broadcasting, this dissertation was specifically interested in hearing from Canadian households that lost access to $\mathrm{CBC} /$ Radio-Canada television. While FCB is "not affiliated with any broadcaster or political party" and strives "to defend and enhance the quality and quantity of Canadian programming in the Canadian audio-visual system" (FCB, n.d.) any potential bias from interviewed research respondents who were also members of FCB was mitigated by the fact that this dissertation neither focused on the "quality and quantity of Canadian programming" nor whether interview respondents had also lost access to other Canadian radio or television broadcasters. This dissertation's aim was to make contact with households that lost access to $\mathrm{CBC} /$ Radio-Canada television as a result of the public broadcaster's response to Canada's digital television transition since the lived experiences of television viewers residing within such disconnected households made them experts within their field (regardless of any organizational affiliations). Furthermore, the research questions posed by this dissertation dealt with barriers to CBC/Radio-Canada television access illuminated by CBC/Radio-Canada's analogue OTA television service shutdown and how households responded to such barriers and did not entail more normative questions pertaining to what sort of audio-visual policies the government of Canada should or should not be providing its citizens. 
In terms of the selection of interviewees from the pool of OTA television-viewing respondents, the only requirement was that a household lost analogue OTA access to one or more of CBC/Radio-Canada television services, at some point, between 2011 and 2012. Research participants were then e-mailed or mailed a Research Ethics Board (REB) release form for review and signature. Research interviews were conducted with research participants on a first come, first served basis once they had returned a signed release form. However, in terms of geography, an effort was made to select eligible research participant candidates from across Canada. In the end, CBC/Radio-Canada television viewers from every Canadian province and territory other than Nunavut were interviewed.

Demographic information obtained from interviewed CBC/Radio-Canada OTA television viewers included age, gender, vocation, and province/territory of residence. Each household was also assigned its own OTA interview number (such as OTA001, OTA002, and so on). As listed in Appendix 1, the demographic breakdown of the 99 household interviews included an average age (when given) of 58 and a gender breakdown of 51 female/50 male (two of the households interviewed included a female interviewee and a male interviewee). The most common vocations (when given) were Retired/Semi-Retired (31), Teacher (7), Artist (5), and Self-employed (5). The province or territory of residence at the time of the initial household interviews included Ontario (30), Québec (19), Nova Scotia (12), British Columbia (8), Newfoundland and Labrador (7), Alberta (6), Manitoba (5), Yukon (5), Saskatchewan (3), Prince Edward Island (2), New Brunswick (1), and Northwest Territories (1). Demographic information and the names of the members of CBC/Radio-Canada Management interviewed for this dissertation are not included for reasons of confidentiality. Each CBC/Radio-Canada Management interviewee has each been assigned a unique MGMT interview number. 
Interviews commenced in July 2012 and were conducted via Skype-to-landline, inperson, telephone, Twitter Direct Message (DM), and/or e-mail. In terms of sampling, Semistructured interviewing was used to allow research participants to advise on their post-analogue television access to $\mathrm{CBC} /$ Radio-Canada programming in a manner that was unique to their specific household and that may not have been captured via structured interviewing. Indeed, responses from interviewed research participants revealed complications tied to access that were not originally anticipated and semi-structured interviewing prompted additional questions and yielded additional findings. Semi-structured interviewing provided a level of interpretation and discovery that Miles, Huberman \& Saldana (2014) describe below,

Kvale and Brinkman (2009) point out that during an open-ended interview much interpretation occurs along the way. The person describing his or her "life world" discovers new relationships and patterns during the interview; the researcher who occasional summarizes or reflects what has been heard is, in fact, condensing and interpreting the flow of meaning. Data are not being collected but rather coauthored (p. 37).

By November 2012, research interviews with new research participants ended. Research interviews after November 2012 were limited to follow-up correspondence, mainly by way of email, with research participants whom had already been interviewed for this dissertation between July and November 2012 .

In terms of the primary research matrix analysis preparation, "descriptive coding" (Miles, Huberman \& Saldana, 2014, p. 74) was used. The codes for the first pass of coding included three data categories; Reception Before Analogue Shutdown, Reception After Analogue Shutdown, and Reception Adaptation (meaning, how did households adapt, if at all, in the hopes of regaining access to $\mathrm{CBC} /$ Radio-Canada's television programming). While some grammatical corrections were made to the research interview responses collected, an effort was made to retain 
the local dialect of each television-viewing household interviewed. A translator was hired to translate French language interview responses into English. 


\section{Methodological Approach}

This section outlines the methodological approach of this dissertation. As noted earlier, this dissertation embraces a methodological approach to understanding changes to television delivery as informed by the political economy of communication. This dissertation strives to add to the body of knowledge pertaining to how CBC/Radio-Canada's response to Canada's 2011 digital television transition deadline corresponds to access to the public broadcaster in the digital age.

As defined by Vincent Mosco (2009), political economy entails "the study of the social relations, particularly the power relations, that mutually constitute the production, distribution, and consumption of resources, including communication resources" (p. 2). More generally, Mosco (2009) notes that political economy entails "the study of control and survival in social life” (p. 25). As noted by Robert W. McChesney (2013), the political economy of communication (PEC) allows media and communications to be studied in two main ways,

First, it [PEC] examines the institutions, subsidies, market structures, firms, support mechanisms, and labor practices that define a media or communication system...[PEC] examines how these structural and institutional factors shape the content of media and how communication systems function in society...Second, the PEC emphasizes the foundational role of government policies in establishing media systems, even commercial profit-driven systems. The PEC studies and assess how communication policies have been debated and determined, and it has a strong historical component looking at how media policies and systems were created in the past (p. 64).

When examining the role of technology in society, McChesney (2013) notes that it is best to approach the field as "political economy and communication. The PEC is not just about making a structural analysis of communication systems and policy debates, as important as those are. Its practitioners also analyze how communication defines social existence and shapes human development" (p. 69). While McChesney admits that the work of Harold Innis and Marshall 
McLuhan on the impact of technology can at first "smack of media technological determinism", McChesney notes that "with the PEC this approach highlights the media technologies have significant impact....Innis did not only focus upon the importance of communication technologies; he was also a sharp critic of corporate media and media commercialization" (2013, p. 69). Furthermore, McChesney notes that,

PEC cannot and does not say much about aesthetics or the nature of content, nor does it analyze the way audiences deal with media content. The PEC does look at structural and institutional factors and assess what types of pressures exist that will shape the content. The catechism asserts that commercial media "give the people what they want", that the audience barks out orders and media firms race to satisfy them in a direct and unambiguous relationship. The consumer is king. The PEC examines these claims (2013, p. 73).

Indeed, PEC allows the research interviews synthesized in Chapter 6 of this dissertation to be used to critically examine the claims made by the Government of Canada, the CRTC, Industry Canada/ISED, Canadian Heritage, and CBC/Radio-Canada about post-analogue access to the public broadcaster's television programming. Government regulation, protectionism, subsidies and other cultural and industry incentives have always been an important part of Canada's broadcasting and telecommunications industry and specifically the provision of access to CBC/Radio-Canada television programming. Adam Smith's (1998) reminder that "(i)t is not from the benevolence of the butcher, the brewer, or the baker, that we expect our dinner, but from their regard to their own interest" (p. 22) offers insight into the level of access to the public broadcaster's television programming that might be expected from Canada's verticallyintegrated BDUs if regulations currently in place to facilate such access to $\mathrm{CBC} /$ Radio-Canada were to be removed.

By forcing television broadcasters to switch to digital and vacate the valuable $700 \mathrm{MHz}$ ultra high frequency (UHF) spectrum previously used for analogue over-the-air television 
broadcasts (Channels 52 to 69), the Government of Canada risked that the move could impact the digital divide in Canada by affecting access to television signals. By connecting citizenship to communication rights and cultural citizenship, Canada's digital television transition can be seen as a possible "means to exclude people from the benefits of membership in a collective" (Mosco, 2009). As stressed by Marc Raboy (2010), the Broadcasting Act states that broadcasting in Canada is "a public service essential to the maintenance and enhancement of national identity and cultural sovereignty" and that it functions as a regulated "system of communication and not merely as a medium of entertainment" (p. 104).

On the matter of the history of government regulation of communications, David Harvey (1989) notes that following World War II, the "geographical expansion of transport and communications systems, and infrastructural development both within and outside the advanced capitalist world" involved the state "[taking] on new (Keynesian) roles" to help support previous modes of Fordist accumulation (p. 132). For Harvey (1989), postwar Fordism was "less a mere system of mass production and more a total way of life" that included "mass consumption" and "a commodification of culture" (p. 135). Furthermore, Harvey (1989) argues that,

Fordism also built upon and contributed to the aesthetic of modernism - particularly the latter's penchant for functionality and efficiency - in very explicit ways, while the forms of state interventionism (guided by principles of bureaucratic-technical rationality) and the configuration of political power that gave the system its coherence, rested on notions of a mass economic democracy welded together through a balance of special-interest forces. ( $p$. 136).

Harvey (1989) notes that the 1973 recession prompted OECD economies to seek new modes of global and mobile "flexible accumulation" geared toward "the ferment, instability, and fleeting qualities of a postmodernism aesthetic that celebrates difference, ephemerality, spectacle, fashion, and the commodification of cultural forms" (p. 156). As such, Harvey (2007) 
argues that the "state is now in a more problematic position. It is called upon to regulate the activities of corporate capital in the national interest at the same time as it is forced, also in the national interest, to create a "good business climate" (p. 170). This collective insight from Harvey helps to provide insight into why it was that Canada was so keen on reallocating the country's $700 \mathrm{MHz}$ band of spectrum and why OTA television-viewing households located beyond densely populated and lucrative urban television markets were seemingly a non-priority.

Further insight into the plurality of publics present within the singular public interest is found in research conducted by Livingstone, Lunt, and Miller (2007) regarding use of the term “citizen-consumer" by the U.K. broadcasting and communications regulator Ofcom. The authors' research found that the notion of a hyphenated citizen-consumer and the use of such terminology in regulation resulted in a scenario where "citizen (or public) interests risk being marginalized as the power elites (industry, state and regulator) reproduce and naturalize a consumerist discourse of communications regulation" (2007, p. 64). The reason for this, as argued by the authors, was due to the fact that "issues positioned as real are worthy of attention whereas those positioned as social constructs can be dismissed. Since consumer issues fit the former category, they are being taken 'extremely seriously'... [whereas] the citizen interest is, by contrast to the consumer interest, difficult to define clearly" (2007, p. 73).

The challenges that Ofcom had demonstrated in articulating and serving the UK citizen interest, as reported by Livingstone, Lunt, and Miller (2007) are comparable to the challenges that the CRTC in Canada has faced with respect to articulating and serving the Canadian public interest. In the case of Ofcom, Livingstone, Lunt, and Miller (2007) found that citizen issues, when articulated, were defined as "whatever important is left over after determining first what markets alone can achieve" (p. 75). Furthermore, even when citizen interests were discussed, 
such interests were relegated solely to the experiences of "vulnerable citizens" and "disadvantaged groups, with no acknowledgement of alternative conceptions of citizenship" (Livingstone, Lunt, and Miller, 2007, p. 82). As a result, "[t]he outcome is a conception of the citizen as a vulnerable minority, leaving the majority to express their citizen interest primarily through their active role as consumers in the marketplace" (Livingstone, Lunt, and Miller, 2007, p. 85).

Similarly, in his book on cultural citizenship Toby Miller (2007) details how the privatization of goods involves a process of "transforming the citizen into a consumer governed via cultural niches, and the cost of such developments to progressive politics" (p. 23). Citing Michel Foucault, Miller (2007) argues "we need to undertake research 'not at the level of political theory, but rather at the level of the mechanisms, techniques, and technologies of power' (Foucault 2003a, 37, 29, 241)" and calls for a critical "analysis of contemporary life" starting with Miller's (2007) detailed critique of the trifecta of television genres fixated on terrorism, foodie culture, and severe weather. For Miller (2007), the "freedom to participate in culture is contingent on both freedom from prohibition and freedom to act via political, economic, and media capacities" (p. 73). Miller (2007) argues that "doctrines of cultural citizenship can work toward a more equitable world if they reject the technicism, utopianism, liberalism, nationalism, and neoliberalism of business-as-usual cultural citizenship, and recognize their reliance of deregulatory consumerist projects as much as leftist social-movement populism" (p. 179).

Vincent Mosco's (2004) focus on the "political economy relationship between digitization and commodification" (p. 154) helps to reveal how the political economy of television remains tied in the digital age to how television is distributed. Mosco's work also 
reveals how neoliberal notions of digital efficiency can impact access to public services. As Mosco (2009) notes, "[e]ach step toward the digitization of television has refined the commodification of content" (p. 136). While digitization of information provides opportunities for "significant gains in efficiency of communication networks", Mosco (2004) importantly notes that digitization also includes the "process of commodification or the transformation of use to exchange or market value" (p. 155-156). As Mosco (2004) outlines,

The expansion of the commodity form provides what amounts to the material embodiment for digitization. It is used first and foremost to expand the commodification of information and entertainment content, enlarge markets in the audiences that take in and make use of digitized communication, and deepen the commodification of labor involved in the production, distribution and exchange of communication...In other words, commercial forces deepened and extend the process of digitization because it enables them to expand the commodity form in communication...Digitization expands the commodification of content by extending opportunities to measure and monitor, package and repackage entertainment and information. (p. 156).

Seven years prior to Canada's 2011 digital television transition Mosco (2004) was asking the important question, "[h]ow does one package a television program for sale to a viewer?" (p. 157). While noting that the delivery of television has always involved a process of commodification, Mosco argues that "the digitization of television has refined the commodification of content, allowing for the flow to be "captured" or, more precisely, for the commodity to be measured, monitored and packaged in increasingly more specific and customized ways" (p. 157). Digitization allows BDUs to more accurately detail audiences/users and "refines the commodification of viewers over the Fordist system of delivering mass audiences to advertisers" (Mosco, 2004, p. 158).

As explained by Vincent Mosco (2004), "[t]he mutual constitution of digitization and commodification contributes to the integration of the communication and information technology sector and concentration of corporate power within it" (p. 159). This integration 
took form as the technological convergence provided by the digitization of information and networked computing, as discussed earlier in this dissertation. Mosco (2004) stresses that the traditional divisions between different media that have since become blurred were "historically important because they contained the legal and institutional marks of the particular period in which they rose in prominence" (p. 159). This was certainly the case for the start of analogue television broadcasting in Canada and radio broadcasting before that. Mosco (2004) notes that "[t]he information technology or computer data industry took off in the post-World War II era and embodies the trend away from nation-state regulation, except to advance the expansion of businesses" and as such "the computer industry would face little or no public-interest or public-service responsibilities, no subsidized pricing, no commitment to universality of access" (p. 159-160).

In terms of the digital sublime and digital myths, for Mosco (2004) "it is when technologies such as the telephone and the computer cease to be sublime icons of mythology and enter the prosaic world of banality - when they lose their role as sources of utopian visions - they become important forces for social and economic change" (p. 6). For Mosco, "myths are stories that animate individuals and societies by providing paths to transcendence that lift people out of the banality of everyday life. They offer an entrance to another reality, a reality once characterized by the promise of the sublime...Myths are not true or false, but living or dead" (2004, p .3). Mosco notes that "myths are not just a distortion of reality that requires debunking; they are a form of reality. They give meaning to life, particularly by helping us to understand the seemingly incomprehensible, to cope with problems that are overwhelmingly intractable, and to create in vision or dream what cannot be realized in practice" (2004, p. 13-14). Public speeches by the former Industry Canada and the CRTC 
regarding Canada's 2011 digital television transition and the plans for Digital Canada certainly embody such dreams of digital to provide continued growth and better service to Canadians.

A prominent digital dreamer is Nicholas Negroponte. Best known for his book Being Digital (1995/2001), Negroponte expressed concern in the mid-1990s that future access to American television could position the "TV as a Tollbooth" in terms of fees charged by U.S. cable television "providers" for access to high-definition digital television (HDTV) and questioned whether such an approach to future television delivery was "in the public's best interest" (p. 45). Instead, Negroponte argued that the computerization of television would avoid the "compromised" approach of the American cable industry and its "monopolistic impulses" (1995/2001, p. 46). Rather than a television future akin to a tollbooth, Negroponte argued that "the TV as Computer" would render HDTV "stillborn" at its forecast due date at the 1996 Atlanta Summer Olympics since "nobody will care, and as many as 20 million Americans could be watching NBC in a window in the upper-right-hand corner of their personal computer screens" (1995/2001, p.48) and that "by the year 2005 Americans will spend more hours on the Internet (or whatever it is called) than watching network television" (1995/2001, p. 58). As proclaimed by Negroponte (1995/2001),

Being digital is the option to be independent of confining standards. If your TV does not speak a particular dialect, you may have to visit your local computer store and buy a digital decoder, just like you buy software for your PC today. (p. 44)

For Negroponte the main impediment to open media access was the U.S. broadcast and telecommunications regulator, the Federal Communications Commission (FCC), or as Negroponte dubbed the FCC, "the Bit Police" (1995/2001, p.51). Negroponte argued that the FCC's antiquated analogue approach to spectrum allocation, television licensing and cross- 
ownership rulers were the problem (1995/2001) and that the world of "bits" facilitated by computers and the Internet would create a future landscape where, quite amazingly, "[t]he medium is no longer the message" (1995/2001, p. 61).

Negroponte's enthusiasm for digital was embodied in the idea of "Digital Canada" as expressed by the past Canadian government of Prime Minister Stephen Harper. As noted in the introduction of Digital Canada 150 2.0, Canada's last Minister of Industry James Moore with regards to citizen access to digital media notes that,

A plan to unbundle cable and satellite TV packages to give Canadian consumers more choice and customizable on-demand options... will allow them to pick and pay for the specific channels they want. The CRTC decision will come into effect by December 2016, giving Canadians consumers more control over the TV they want to watch. (Industry Canada, 2015, p. 4)

As noted earlier, nowhere in Digital Canada 1502.0 is over-the-air (OTA) HD digital television, or $\mathrm{CBC} /$ Radio-Canada at all for that matter, mentioned as a service that could or will continue in the future to assist in providing television access to Canadians. Instead, access to affordable high-speed Internet is the focus, followed by cellphone provider choice and greater BDU television channel choice. When industry, regulators and elected governmental officials speak of digital television delivery in Canada, with the exception of CRTC Chairman Blais's OTA revelation in January 2015, they overwhelmingly focus on digital delivery via broadband Internet and wireless telecom services. Over-the-air digital television broadcasting is rarely included in discussions of the digital television delivery. OTA television broadcasting is so overlooked that it isn't even considered as "traditional" television in Canada since traditional television is understood and named by industry and the government as BDU delivered television, specifically cable television. 
As argued by Vincent Mosco (2004), "[c]ritically examining myths of cyberspace may help us to loosen the powerful grip of myths of the future on present...cyberspace is a mythic gloss on individual achievement and genuine community against the ostensibly backward Others who would undermine both" (p. 15). The research conducted for this dissertation critically examines the myths of digital television delivery and critically considers future changes to Canada's regulated television system. As put by Mosco (2004), “(m)yths can foreclose politics, can serve to depolitize speech, but they can also open the door to a restoration of politics, to a deepening of political understanding" (p. 16).

Vincent Mosco's The Pay-Per Society (1989) also provides a pre-digital understanding of the impact that spectrum commodification has on citizen access to broadcasting and communications. Succinctly summarizing Canada's 2011 digital television transition and $700 \mathrm{MHz}$ spectrum auction more than two decades before it had even occurred, Mosco (1989) notes,

[a] movement exists to make the electromagnetic spectrum, the resource used for the transmission of radio, television and other electronic signals, into a marketable commodity. This is not a simple job because the characteristics of the spectrum require that any spectrum commodity take into account, not only the space occupied by the signal, but also the time it is transmitted, the signal strength and several other characteristics. This has not kept economists from proposing that such packages can be developed and sold to the highest bidder, for whatever use, in the open marketplace (1989, p. 33).

Pay-per call, per view, per bit of information, per keystroke, etc eliminates the benefits powerless, poor people and regions enjoyed because of the technical limitations on making every transaction a financial one (p. 35).

On the topic of public broadcasting specifically, Mosco was arguing in 1989 that "the government policy to cut back on funding for public broadcasting services further erodes the Canadian dimension of Canadian broadcasting. In addition, the Canadian regulator, the CRTC, has followed the FCC lead in taking a permissive attitude to industry mergers and the overseeing 
of cable industry rates and services. Canada achieves effective deregulation by making it easier for private US networks to reach Canadians with their programming” (p. 212). By connecting citizenship to communication rights, Vincent Mosco's research into the political economy of television delivery shows how an event like a digital television transition "can be done positively, in order to build internal solidarity, or negatively as a means to exclude people from the benefits of membership in a collective" (Mosco, 2009, p.155).

Speaking to the U.S. digital television transition, Lisa Parks (2013b) notes that the U.S. switch provides valuable insight into the fetishization of digital television delivery in contrast to the preferences of actual television viewers,

While the tendency is to assume that television will be replaced with "smart media," if the DTV transition has shown us anything it is that many people in the United States were deeply connected to and satisfied with the system of free over-the-air analog television despite the availability of "better" services. The DTV transition's fetishization of innovation, manifest in the fixation on a crisper picture, occluded the reality that many people did not need or want DTV and suggested that broadcasters were glaringly out of touch with the ways that many US citizens think about, watch, and use television... The point is that we cannot allow corporate and FCC quests for technological innovation, whether articulated as Google TV or "Wi-Fi on steroids," to determine critical investigations of television's transitions... Television will not simply be substituted with "smart media." It will be reinvented (as it has been many times in the past) across changing infrastructures and platforms and local, national, and global sites. (p. 18-19)

Parks (2013a) has also been striving to "work toward an analysis of technologies of distribution as well as toward more environmental and resource-based understandings of media (Bozak, 20U; Cubitt, 2005; Maxwell \& Miller, 2012)" via what she terms "Earth-observing practices" (p.287). Parks (2013a) notes that what is missing from the existing body of research focused on, for example, U.S. broadcast infrastructures, is "a detailed investigation of the multiple ways that these infrastructures have historically become intelligible to citizenconsumers and intersect with cultures of everyday life as well as a sense of the contrasts across 
industrialized and developing regions, rich and poor areas, urban and rural settings, and literate and oral cultures" (p. 288).

Additional insight into public service broadcasting in the digital age is provided by Benedetta Brevini's (2013) proposed framework for PSBs that extends beyond simply offering traditional PSB services online with Web 2.0 participatory interactive functionality tacked on. Instead, Brevini (2013) proposes "PSB 2.0" which she describes as "a set of new policies regarding online media - a phase 2.0 of PSB - inspired by the PSB ethos" and an approach that "clashes with dominant liberal market ideologies that see liberalization and deregulation as the logical consequences of new technological development" (p. 31). Critiquing market ideology from the likes of Negroponte and others who suggest that the Internet provides PSBs with the ability to provide services to the public "regardless of ownership or economic structure" (p. 31), Brevini (2013) argues instead that "the political economy tradition has demonstrated that the scenarios opened by new technologies are always moulded by political, economic and cultural factors (Freedman, 2002; Mansell, 1996; Syvertsen, 2003; Williams, 1974, 19B5)" (p. 32). Similar to Livingstone, Lunt, and Miller (2007), Brevini (2013) critiques the notion of a consumer-citizen and advocates for a form of citizenship that entails civil, political, social, and communication rights (p. 42).

For Brevini (2013), PSB 2.0 is based on the components of citizenship, universality, quality, and trust (p. 32). In terms of universality of access, Brevini (2013) stresses that PSB 2.0 identifies two challenges with regards to access:

On the one hand, there are issues of access to the technology and more specifically the networks; on the other hand, there is access to content that brings about discussions on copyright, which must carry rules and issues of retrievablility. (p. 44). 
Brevini's (2013) "Components of universality" model illustrated in the pyramid pasted below is reminiscent of both Maslow's Hierarchy of Needs and Clement and Shade's Access Rainbow (2000).

Figure 1. Brevini's Components of Universality model (Brevini, 2013, p. 45)

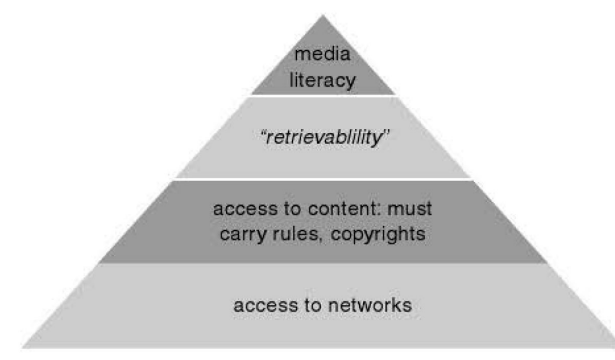

As outlined by Brevini, access to two-way modes of communication such as broadband Internet and mobile networks "must be guaranteed" in order to bridge the initial barrier of the digital divide (2013, p. 44). Brevini notes that guaranteed access to such networks is a core challenge for PSB 2.0 since "unless PSBs own a broadcasting network, in order to achieve universality of access to networks, they will always have to rely on private providers" (2013, p. 45). Once access to such network(s) is achieved, Brevini notes that PSB 2.0 next requires access to content that includes must-carry regulation and copyright barriers. On the note of copyright specifically, Brevini makes the innovative suggestion that all PSB 2.0 content use creative commons licensing, thus resolving barriers to access based on copyright restrictions (2013, p. 46). Lastly, Brevini's access pyramid requires that citizens be able to find PSB 2.0 content (retrievability) and also know how to use digital technology (media literacy) (2013, p. 46).

As referenced earlier, Andrew Clement and Leslie Regan Shade's (2000) Access Rainbow provides a seven layered model for assessing universal access to information/communication infrastructure (ICI) within digitally networked environments (p. 12). As outlined below, the layers of access identified by Clement \& Shade (2000) are carriage 
facilities, devices, software tools, content/services, service/access provision, literacy/social facilitation, and governance. As explained by Clement \& Shade (2000), their Access Rainbow model was "(i)nspired by the layered models used for network protocols":

The lower layers emphasize the conventional technical aspects. These have been complemented with additional upper layers emphasizing the more explicitly social dimensions. The main constitutive element is the service/content layer in the middle, since this is where the actual utility is most direct. However, all the other layers are related to each other and are necessary in order to accomplish proper content/service access. (p. 35)

Figure 2. Clement \& Shade's Access Rainbow (Clement \& Shade, 2000, p. 36)

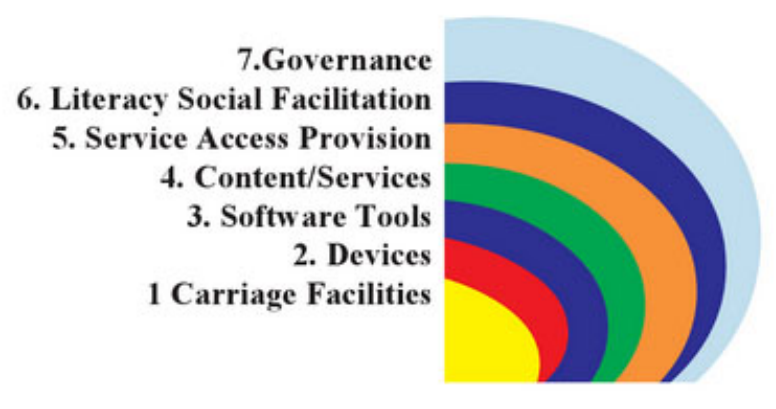

Clement \& Shade (2000) note that "it is important to challenge prevailing marketoriented rhetorics which undermine the principle of universality of services benefitting everyone. Citizens should not face a degradation of existing services until they have superior alternatives to choose from" (p. 34). Challenging market-oriented regulatory solutions is helpful when assessing the provision of household access to $\mathrm{CBC} /$ Radio-Canada television programing following the public broadcaster's operational response to Canada's 2011 digital television transition deadline. As noted by Clement \& Shade (2000), the "distinct but interoperable" (p. 35) layers of their access rainbow "reflect the important regulatory separation of carriage and content" (p. 35),

This distinction has a long history, going back to the regulation of railroads, but remains relevant as we witness the rapid growth of huge, vertically-integrated, global media 
conglomerates that threaten to impose monopolistic or oligopolistic control over vital societal infrastructure. (p. 35)

In a post-analogue television access environment facilitated in part by the IP-based delivery of television care of Canadian ISPs and mobile wireless providers regulated under the Telecommunications Act, an act that addresses the free flow of "intelligence" rather than Canadian public television programming, the lack of regulatory separation between carriage and content as noted by Clement \& Shade (2000) does present concerns related to universal access to CBC/Radio-Canada television programming by means other than regulated OTA broadcast or BDU delivery.

This chapter outlined this dissertation's methodological rationale and approach. Semistructured interviews were sought from OTA CBC/Radio-Canada television-viewing households and members of CBC/Radio-Canada Management with the aim of obtaining insight into how they experienced and perceived access to $\mathrm{CBC} /$ Radio-Canada television programming before and after CBC/Radio-Canada's operational response to Canada's digital television transition. Use of the political economy of communication (PEC) as a methodological approach aided in grounding this dissertation's analysis of the research findings via the power relations (Mosco, 2009) that comprise both analogue and digital communications.

The next chapter will present the findings of this dissertation. The first set of findings that are presented are based on the interviews conducted with OTA CBC/Radio-Canada televisionviewing households that lost OTA access to the public broadcaster at some point between 2011 and 2012 as a result of the CBC/Radio-Canada's operational response to Canada's digital television transition. The second set of findings are based on interviews conducted with members of CBC/Radio-Canada that were involved in CBC/Radio-Canada's operational response to the transition. 


\section{Chapter 6: Findings}

This chapter features the research interviews conducted with Canadian over-the-air (OTA) CBC/Radio-Canada television-viewing households and members of CBC/Radio-Canada Management on the topic of CBC/Radio-Canada's operational response to Canada's 2011 digital television transition deadline. It is from these research interviews that two differing accounts of CBC/Radio-Canada's analogue OTA television transmitter shutdown and digital OTA television transition emerge. The first account is provided by 99 OTA CBC/Radio-Canada televisionviewing Canadian households that lost OTA access to one or more CBC/Radio-Canada television station following the public broadcaster's analogue OTA television service shutdown. The second account is provided by five members of CBC/Radio-Canada Management interviewed on the same topic of CBC/Radio-Canada's analogue OTA television service shutdown and digital OTA television transmitter rollout. While these two groups do at times tell similar stories related to CBC/Radio-Canada's analogue OTA television service and its approach to Canada's digital television transition, they often present competing accounts of the role that OTA television infrastructure plays in the provision of access to $\mathrm{CBC} /$ Radio-Canada television programming. In addition, these research findings present differing manifestations of the role that the "cult of efficiency" (Stein, 2001) has played in post-analogue access to CBC/RadioCanada television programming and of how the recently approved reallocation of Canadian's $700 \mathrm{MHz}$ band of electromagnetic spectrum is linked to the public broadcaster's ability to provide such access. 


\section{A) Canadian OTA CBC/Radio-Canada television-viewing household interviews}

This section presents findings from the interviews conducted with 99 OTA CBC/RadioCanada television-viewing Canadian households that lost OTA access to the public broadcaster following the shutdown of its analogue OTA television service. As outlined below, findings from the OTA CBC/Radio-Canada television-viewing households interviewed for this dissertation suggest that analogue OTA television broadcasting was providing such households with access to the public broadcaster's television services in a meaningful way, right up until the moment analogue OTA access was cut.

\section{Access to CBC/Radio-Canada television via analogue OTA broadcasting}

1) Cost

I think I've paid for that content already. (OTA043)

75 of the 99 OTA CBC/Radio-Canada television-viewing households interviewed for this dissertation noted cost as a reason for their viewing of CBC/Radio-Canada television by way of over-the-air broadcast. 26 households specifically expressed an interest in receiving CBC/Radio-Canada television programming for "free/gratuitement". OTA035 noted that, "the only free channel that we would get would be CBC, traditionally" and OTA056 noted that with “(OTA) being free, it means you get good value". However, mention of television access in relation to cost was typically more nuanced than households simply wanting television without any charge at all. Since CBC/Radio-Canada's analogue OTA television service was available to the household via the public broadcaster's analogue OTA television transmitters/retransmitters, and there was no additional fees or financial penalties to access it, $\mathrm{CBC} /$ Radio-Canada television 
was watched. As noted by OTA045, "I've never paid for cable. I spend a lot of time on the road hence I can't see the point of paying for something if I'm not going to be using it".

Beyond simply a desire for free/gratuitement TV, there was a normative sense expressed by 57 interviewed households that $\mathrm{CBC} /$ Radio-Canada had an obligation to provide accesss to CBC/Radio-Canada television programming without any additional charge(s) being incurred by households. As noted by OTA070, CBC/Radio-Canada "should be providing a public service, in other words a free public service". For OTA047, CBC/Radio-Canada is "publicly funded, it comes out of our taxes.... I shouldn't have to pay any private company to get it", and for OTA015 there was a sense that CBC/Radio-Canada TV delivery had been pre-paid: "no cost public access is important with the CBC. Not with the others. Taxpayers shouldn't have to pay to make it and then pay to get it". Meeting monthly household bills was also noted by OTA096 who remarked, “We're on a pension. We don't really want to pay $\$ 60, \$ 70$ per month for satellite TV. People out here aren't rich. This is not Alberta".

A focus on the cost for interviewed households to access CBC/Radio-Canada television speaks to the nonrival and nonexcludable qualities of OTA television broadcasting. Anyone who might benefit from viewing $\mathrm{CBC} /$ Radio-Canada television programming was able to since the additional cost to access an analogue OTA CBC/Radio-Canada television feed was zero. However, there are nonetheless actual hard costs associated with the provision of such television programming by $\mathrm{CBC} /$ Radio-Canada. Contrary to statements from interviewed households that the household's access to CBC/Radio-Canada television programming had already been paid for, the annual funding appropriations paid to $\mathrm{CBC} /$ Radio-Canada from Canadian taxpayers typically only cover roughly two thirds of the public broadcaster's annual budget. 


\section{2) Availability}

We've always been able to get CBC fine from the antenna. (OTA004)

The availability of CBC/Radio-Canada's analogue OTA television service factoring into household viewing of CBC/Radio-Canada television programming was a comment made by 63 of the 99 CBC/Radio-Canada television-viewing households interviewed. OTA009 noted, "I've been watching CBC for years. I have a small TV but CBC has always come through wonderful”. OTA017 noted, "I just had a regular television set and I was able to access Montréal stations without difficulty", OTA060 "had no problem to get those two stations", and OTA004 had "always been able to get CBC fine from the antenna". In addition, OTA029 noted "(b)efore the transition to digital, I accessed Radio-Canada with my regular television without cable, sometimes with the need of a little antenna, but not always" and OTA081 noted, "I always received the Radio-Canada and CBC signals with simple rabbit ear antennae". OTA095 noted "we just had the antenna. That worked fine then" and OTA063 noted "I could get it if I fiddled with it enough".

OTA038's comments about household analogue OTA CBC/Radio-Canada television availability stressed simplicity: "It's simple. It's just so simple. You can put up your rabbit ears and you've got something...It worked good and it was semi-reliable, unless the power went out". In other cases, while some effort was required to fine-tune analogue OTA reception, such efforts were rewarded with a signal. OTA088 noted, "traditionally, we had rabbit ears with wires hooked up to it or tinfoil or whatever other accoutrements we could find to get a signal". OTA045 noted that, "I live in a neighbourhood where it's not very easy to catch it...you have to play with your antenna and it's never that clear but it's good enough for me". 
Since the technology involved with the delivery of analogue OTA CBC/Radio-Canada television was relatively unchanged since 1952, the level of technological literacy required to receive the public broadcaster's OTA transmissions had been consistently low. As such, tuning in $\mathrm{CBC} /$ Radio-Canada television over-the-air television signal(s) required low technological literacy. Viewers did not have to spend a great deal of time, energy, and finances to capture CBC/Radio-Canada's signal(s). OTA054 mentioned how "Radio-Canada, the French station, was something that we'd throw on a Saturday morning and watch kids cartoons with". In other cases, as noted by OTA016, analogue $\mathrm{CBC/Radio-Canada} \mathrm{television} \mathrm{"reception} \mathrm{wasn't}$ necessarily the best but it was doable". For OTA061, "satellite for us wasn't really a viable choice... we went to rabbit ears....we're down a little bit of a valley. As far as Internet goes or satellite Internet, we can't pick up anything... we are at the mercy of the $\mathrm{CBC}$ and analogue. That's all we can do". In one case, a research participant did not even own a television set and would instead listen to the audio only from CBC Television analogue broadcasts using a VHF radio (OTA059).

Nine research participants noted that $\mathrm{CBC}$ and/or Radio-Canada television was the only OTA television signal(s) available to the household. Otherwise, viewers reported receiving one or more analogue OTA television signals from different broadcasters, most often CTV and Global and sometimes TVO, Knowledge, or APTN. Nine households also noted reception of OTA television signals emanating from the United States.

With regards to the availability of other modes of television delivery to the households interviewed, close to a third (30) of household interviewees noted that cable television service was not offered in their community. Cable television providers either did not serve their area at all, or refused to run a line to the household without the household paying additional fees above 
and beyond typical installation fees. The same number of households also noted that accessing CBC/Radio-Canada television on a cell phone was not feasible due to a lack of area cell phone signals and/or a cell phone that was suitable for television viewing. While 74 research participants interviewed noted that they did have Internet service, 30 of the households with Internet advised that it was not a viable replacement for OTA television due to issues relating to maintaining a constant Internet video stream. While $\mathrm{C}$-band, and later $\mathrm{Ku}$ band, satellite television had hypothetically been viable options for the households interviewed for many years, in terms of receiving CBC/Radio-Canada television services by satellite, 31 households interviewed did not want to subscribe to a paid BDU service as a matter of principle. BDU television delivery may have been cost efficient for $\mathrm{CBC}$ /Radio-Canada in terms of the delivery of its television programming to BDUs, but this did not necessarily translate into improved or comparable television programming availability for CBC/Radio-Canada television-viewing households.

\section{3) Functionality}

The analogue signal reached. It was a little snowy but that was OK. (OTA044)

In terms of the functionality (in other words, the accessible audio-visual quality of a television connection) of CBC/Radio-Canada's analogue OTA television service, household comments on signal quality ranged from "excellent" (OTA067) and "very good" (OTA095) to "haphazard at best" (OTA088). For OTA016, "reception wasn't necessarily the best but doable" and OTA018 claimed that "the CBC signal used to be quite good. Best of the three". OTA082 noted "we got a very good analogue signal" and OTA065 noted "I did have the oreilles de lapin, the rabbit ears. Depending on where I lived the reception of the waves was anywhere from good 
to mediocre". OTA052 noted "of course with the rabbit ears, having an analogue signal, you're always forever having to toy with the antennae trying to get a better picture".

In terms of audio-visual signal quality, OTA011 described how "the signals back in the old analogue days were fairly poor, lots of snow, OK sound quality, but I was able to get the CBC". As noted by OTA063, "I was watching CBC over my TV with bunny ears...it got snowy in recent years". For OTA088, "it was usually snowy. The odd day we'd get a clear signal". OTA040 noted how analogue CBC/Radio-Canada signal quality was poor but it worked:

I was right on the western edge of being able to receive that transmission and it was fuzzy and some nights were better than others. I could hear it fine and I could usually see it but I wouldn't be able to read the writing underneath someone's name or something but I could see the weather maps and stuff but I wouldn't necessarily be able to read the towns and that has been how I've seen the television for the last years.

Reception of more than one CBC/Radio-Canada television station via analogue OTA broadcast was also reported by 22 households. For OTA010, "I had no trouble getting CBC Television in French...I could almost always get some sort of service/reception out of Kingston and I could almost always get two Radio-Canada stations in French all the time out of, I guess out of, Ottawa/Gatineau”. For OTA023, "I'd always had good reception of the Ottawa CBC channel 4. Then there's Kingston Channel 11, that's a CBC affiliate”.

While CBC/Radio-Canada's analogue OTA television service was not HD, it nonetheless provided a signal quality that interviewed households were willing to tolerate. Households interviewed did not note that they watched CBC/Radio-Canada's analogue OTA television service for its audio-visual quality. While four households mentioned an interest in HD programming, households were otherwise interested in the access factors of cost, availability, functionality, à la carte delivery, and locally relevant feeds as outlined in this section. Ironically, the focus on the HD picture and sound of digital television delivery that dominated the early 
hype of Canada's digital television transition as stated by CBC/Radio-Canada Management interview participant MGMT001 as a reason why CBC/Radio-Canada has declined to implement digital OTA multicasting, was not a top priority for analogue OTA CBC/Radio-Canada television viewing households interviewed.

\section{4) A la carte}

All I really want is CBC. (OTA088)

In a dozen cases, $\mathrm{CBC} /$ Radio-Canada television was the only programming that interviewed OTA CBC/Radio-Canada television-viewing households wanted access to in terms of their television. In this sense, analogue OTA CBC/Radio-Canada television signals provided households with a form of à la carte access, in other words the ability to pick an available OTA $\mathrm{CBC} /$ Radio-Canada television station and to watch as much of that station as desired. Such access was offered to households located within the reach of an analogue CBC/Radio-Canada OTA television transmitter prior to the introduction of the CRTC's affordable basic package BDU television regulations in 2016. If an OTA television-viewing household only wanted CBC/Radio-Canada television, local analogue OTA CBC/Radio-Canada transmitter(s) delivered the station(s) they wanted. As noted by OTA092, "CBC is the only channel I watch, full stop".

Households served by analogue OTA CBC/Radio-Canada television signals were provided the option of receiving $\mathrm{CBC} /$ Radio-Canada television programming directly from a local transmitter whereas cable and satellite subscription services did not provide such à la carte delivery of the public broadcaster. OTA005 noted that "the only television I had was over-the-air reception and $\mathrm{CBC}$ was probably the station I watched the most. I only had access to two, possibly three stations" and OTA034 said "I do not want cable, I do not want access to American 
programming". OTA044 noted that "cable is all American. I want to see my public broadcaster producing things for me" and OTA066 stated "I don't want a whole bunch of channels. Had been extremely pleased for the most part with what $\mathrm{CBC}$ has to offer". When listing reasons related to not wanting cable or satellite, OTA072 noted that she didn't "really want all the crap that comes with it just so I can have CBC" while OTA086 noted, “I don't want to get cable or satellite and have to get 20 channels when all I want is one or two at the most".

\section{5) Locally relevant feed(s)}

[I]t's nice to have local TV coverage keeping you up to date. (OTA082)

Access to locally relevant $\mathrm{CBC} /$ Radio-Canada television feed(s) was also cited by 11 television viewing households interviewed. "We always just get the local TV stations...CBC, CTV sometimes Global...using rabbit ears", noted OTA064. Of particular interest to research participants was locally relevant news. Many spoke of a fondness for access to their local news shows. As noted by OTA005, "We have a local supper hour news program Compass. People here on PEI fought very hard to maintain it and make sure we continue to have it". Three households noted using local OTA analogue $\mathrm{CBC} /$ Radio-Canada television to supplement their subscription television viewing. For example, OTA008 noted "I have satellite but for local TV viewing I have to rely on the signal from the local tower which has just been discontinued. It's been cut off down here as of today". Furthermore, OTA069 noted that CBC/Radio-Canada OTA played a role in terms of the genres of television programming he was striving to receive:

You need that [satellite] in order to get sports channels TSN and Sportsnet...I had that but at the same time when I go to my bedroom then I don't have that [satellite] hook up then I could still receive $\mathrm{CBC}$... CBC Television and Radio were my main interest and main vehicle for getting news and entertainment...now I won't be able to do that. How it affects viewers is not explicit... Homes that don't subscribe to commercial providers then won't 
be able to receive the CBC....It's not a matter of watching it in the bedroom or not. The real issue is if I have a TV set and all I have is through the rabbit ear or just the

conventional means. That means I would not be able receive CBC. That really is the issue.

Access to local weather was of particular interest to a truck driver interviewed for reasons related to safety: "A local weather forecast is the utmost importance when you're doing something like that there" (OTA083).

Combined, the analogue OTA CBC/Radio-Canada television-viewing household interviews summarized in this section help to explain the reasons why such households used analogue OTA television broadcasts to receive CBC/Radio-Canada television in the twenty-first century. Analogue OTA CBC/Radio-Canada television service(s) was accessible due to cost, availability, functionality, à la carte delivery, and locally relevant feeds.

\section{Access to CBC/Radio-Canada television post-analogue OTA broadcasting}

\section{1) Cost:}

From where I live, the only way I could receive CBC-TV is if I subscribed to a satellite service which is quite costly and I can't afford that. (OTA030)

Concerns related to anticipated or actual fees associated with accessing CBC/RadioCanada television programming by means other than OTA were cited by 81 of the 99 interviewed OTA CBC/Radio-Canada television-viewing households. OTA067 noted, "the only way to receive the digital signal is to pay for cable or for satellite", OTA027 noted, "unless we wanted to go to satellite dish and pay for satellite service then we're out of luck" and OTA095 stated, "to buy a package through cable, well, the least that you pay is about $\$ 40$ and for a whole bunch of channels you don't want. This is the thing that I don't like. They're almost forcing people to buy cable or a satellite package. I don't think that's fair...just to get the one channel'. 


\section{Cable and Satellite Costs}

As noted earlier, the actual or perceived cost of subscribing to either satellite or cable, and the value of such television service, was noted by 81 interviewed households as a barrier

to subscribing to a cable or satellite BDU:

At the moment I don't have a plan, short of winning a lottery. I'm on a fixed income and I don't want to. I would assume from what I've been told I have to get satellite. I've been told by the CBC technician transmission guy in Winnipeg that he claims I'm too far out of the transmission zone even if I had an aerial to be able to get CBC Winnipeg so it sounds as if satellite is my only option and at the moment I'm not prepare to commit myself to a monthly amount that I'm not totally sure I'll easily be able to handle. Barring someone else living with me that has some income to go towards it, or me winning a lottery, probably the next window of my being able to afford television will be after I turn 65 and get old age pension. - OTA040

I've never paid for cable. I spend a lot of time on the road hence I can't see the point of paying for something if I'm not going to be using it -OTA045

From where I live, the only way I could receive CBC-TV is if I subscribed to a satellite service which is quite costly and I can't afford that. -OTA030

We don't get cable out in the country. I'm just far enough out of town that they could run a cable up here but it would cost me and besides I really don't want it. When you look at the cell phone and cable and hydro and house telephone, everybody wants $\$ 60$ bucks a month out of my pocket and I can't afford that in retirement so I don't want to set myself up for it now. That's about it. I can't afford it. It's not worth the money to me. - OTA048

As also noted earlier, 31 households interviewed noted that they refused to pay a BDU to access CBC/Radio-Canada television based on principle:

The idea that I have to go pay somebody now for cable television or whatever, for satellite to be able to get that same programming in my house again or even to have to go buy a new television with a digital, all that kind of stuff, is completely wrong. I could probably get cable television if I wanted it but I don't want it. All I want is the CBC. Because it's publicly funded it comes out of our taxes. I shouldn't have to pay any private company to get it -OTA046

Why would I pay a company to deliver me a signal that should be available to all Canadians over-the-air for free? We pay it in our taxes. We give billions of dollars to the $\mathrm{CBC}$. They flushed it. I guess they wanted to transition to Internet delivery but if you don't have the infrastructure in place how do you hope to deliver the product? -OTA049 
I don't know if I would have been willing to start paying some cable company. Getting hooked up to cable. Because once you do that, I don't think it would be a matter of me just ordering, I just want the CBC. There's always some big package you have to get and there's cost and out of principle (laughs). I don't know that I would have done that. (OTA052)

I object to having to buy cable because I'm buying a lot of things I don't use. I also thought the $\mathrm{CBC}$ was publicly funded and that they should be providing a public service, in other words a free public service. -OTA070

I think if it was a privately owned station, I would say, sure, ya. We've already accepted that we can privatize airwaves and water and so many things. Absolutely, I should be paying more and more and more for this because this is the logic of capitalism. -OTA065

Cable is not an option. Not willing to pay for cable. If they want to pay for my cable, ya, OK, go ahead. You're welcome to do that. -OTA073

The following households shared their creative responses to the loss of OTA access to CBC/Radio-Canada television, solutions that often involved relying on their neighbours;

When I want to see something important I go up to the local Irish pub and they got all kinds of TVs in there. It's walking distance for me. I have a pint while I'm at it. - OTA098

We don't plan on getting cable certainly. I'll either go to someone who has cable or watch it online -OTA058

I have thought about going to cable TV but the expense is so high I've decided just to stick to the practice of occasionally visiting a neighbour. I will continue to visit a neighbour who has cable TV from time to time. But essentially I will not really be reached by CBC television. -OTA059

I no longer watch CBC unless I am visiting friends. I can't understand why they didn't do the same thing that Radio-Canada did with a decoder. - OTA081

Respondents in over half (58) of the households interviewed advised that they purchased additional hardware in the hopes of gaining digital OTA television access to CBC/Radio-Canada television programming but only six households were successful.

\section{Internet and Mobile Costs}

Whether by way of a household fixed broadband connection, a fixed wireless connection, or via mobile wireless connectivity, additional data usage fees specifically associated with 
viewing $\mathrm{CBC} /$ Radio-Canada television programming via the Internet was expressed as a concern

for 15 of the 99 households interviewed:

Our base Internet where we are is $\$ 40$ a month for very little data. As soon as you go over data it's not uncommon for us to get Internet bills for $\$ 150$ for just what I would consider regular Internet access. That's with absolutely no Netflix access, very little YouTube access. As soon as you start streaming that kind of data in rural areas your prices go up OTA035

I can't watch TV on the computer because it would be way too expensive because I use a stick. -OTA038

As far as watching it on the Internet goes, up here anyways there's very limited bandwidth and it's quite expensive paying for the Internet up here so again, I'm not going to watch a bunch of CBC programs on the Internet and you know make my Internet bill go way up. OTA052

We have limited bandwidth with NorthWestTel Internet so we only get $15 \mathrm{~GB}$ a month for what we pay so you can't watch it on there. - OTA070

The only workable solution is to get it through the cellular system because that has coverage where we are but the costs of those data plans for watching TV are astronomical. That's a lot to ask someone to pay to watch a service that they're paying for through their taxes. I looked into getting a Bell service that uses the cellular network so I could go to cbc.ca and stream some of the programs but they're all capped at like, $10 \mathrm{~GB}$ a month or something that you'd out run pretty quickly by just watching The National a few times. Can't get it. All you can get is cellular based Internet which is very expensive. - OTA006

I have a very simple, basic phone. I don't have Internet on my phone. Why do I have to pay money for a new phone just so that I can watch CBC? I'm already paying for it. I think it's my right as a Canadian. - OTA052

I've got the iPhone and I got the $\mathrm{CBC}$ app. If I try to watch a program on $\mathrm{CBC}$ there it's going to cost me a small fortune so I just can't afford to do it. It's not an option. It costs me too much for my usage on my Internet thing. It's pretty hard to pick up. Right now in Ontario I can't pick it up. I can't get any 3G or anything there. I'm lost there. - OTA083

The above-noted research interviews related to the anticipated or actual household cost(s) to continue to receive $\mathrm{CBC} /$ Radio-Canada television programming following the shutdown of the public broadcaster's analogue OTA television service overwhelming indicate that such households would be required to spend more to access television from the public broadcaster 
post-analogue OTA. In terms of the household costs associated with accessing CBC/RadioCanada television via the Internet or mobile wireless service provider, households expressed concern related to financial penalties for going over their monthly data caps.

\section{2) Availability}

We have a computer but I find it hard [to watch $\mathrm{CBC} /$ Radio-Canada television programming online]. Some of the programs I watched, 'watch recent episodes', but they aren't recent. Basically, I lose interest. (OTA042)

As noted earlier, all of the analogue OTA CBC/Radio-Canada television-viewing households featured in this dissertation lost reception to at least one $\mathrm{CBC}$ /Radio-Canada OTA television signal, at some point, as a result of the public broadcaster's analogue OTA television service shutdown between 2011 and 2012. OTA availability of CBC/Radio-Canada television programming did not extend into the digital realm for all but six of the previously analogue OTA $\mathrm{CBC} /$ Radio-Canada television-viewing households interviewed. As noted by OTA004, “(w)e used to have something where you could turn the aerial. So if we particularly wanted to watch $\mathrm{CBC}$ we turn the aerial to receive it better. We actually really got quite good reception on $\mathrm{CBC}$ stations and now we don't at all”. Referencing CBC/Radio-Canada's analogue era of OTA television delivery, OTA055 noted, “(n)ormally I could still receive CBC but now I won’t be able to do that. I had it before". For OTA020, "[a]nalogue was fine but somehow I guess we need a stronger (digital) signal where we live. Can't count on it to work... in analogue, you would get static and the picture might disappear but you can see it". For OTA068, “(b)efore the transition, I had free access to Radio-Canada on my television thanks to the antennas". OTA038 
longed for the ease of analogue OTA availability: "I wish they stuck to what they were already doing”.

The inability of 93 of the interviewed households to regain a signal from their lost OTA $\mathrm{CBC} /$ Radio-Canada television station(s) was not for a lack of trying. Indeed, as previously noted, six of the 99 households interviewed did eventually manage to successfully receive a digital OTA signal from at least one digital OTA CBC/Radio-Canada television transmitters. In five of the six cases, the solution to receiving CBC/Radio-Canada television digital OTA was hardware related,

I had to replace the antenna cable and add the converter. (OTA015)

I did purchase a booster, but without it I don't get much at all. (OTA039)

It left us sometime in the summer in July or August and I bought the digital converter early October (2012)...I have the box plugged into my TV, plugged into the antenna. The antenna, it wasn't just rabbit ears, it also had that circle. It had UHF and VHF. The metallic kind of circle. I'm picking up the $\mathrm{CBC}$ really clear and I assume it's over-the-air. It must be. Does that make sense though? (OTA052)

I found access to Télé de Radio-Canada thanks to buying a television that included an adapter in the device. I can now watch Radio-Canada with an antenna. (OTA068)

We went and bought a digital enabled TV. (OTA088)

With regards to the sixth household that regained OTA television access to the public broadcaster, OTA057, Télévision de Radio-Canada was eventually received after the interviewee read a Radio-Canada ad in the newspaper advising that changes had been made to the area OTA transmitter and that households should rescan their digital television converters.

In terms of 93 of the 99 OTA households interviewed that were unable to receive OTA $\mathrm{CBC} /$ Radio-Canada television following the public broadcaster's analogue OTA television 
service shutdown, in one case a Québec household, OTA067, was pre-emptively advised by a local BDU not to even bother trying to receive a digital OTA television signal from the public broadcaster, "I thought it would have been possible to buy myself a decoder to receive the signal for free, but the local cable distributor informs me that this is not possible on the Îles de la Madeleine".

\section{Cable and Satellite Availability}

With respect to subscribing to a cable television provider (either a traditional cable television provider or a telecom television provider) in order to watch $\mathrm{CBC} /$ Radio-Canada television programming, 30 of the analogue OTA CBC/Radio-Canada television viewing households interviewed noted that cable connection was not available in their community:

Up here we don't have cable. We got nothing. (OTA053)

Cable does not reach as far as my home so, I'm out of luck as far as TV goes. I'm in a rural area where there's no cable. (OTA014)

I've never lived with cable which doesn't exist on my road anyway. I can't get cable. (OTA016)

We've lived in the country so we've always used over-the-air TV because we couldn't get cable or any other reliable service. (OTA006)

We don't have cable here. We don't even have cell phone service here. We're somewhat out of the way. (OTA011)

It turns out where I'm located you can either go cable or a satellite but I live across the Winnipeg River so the cable doesn't come over here. (OTA062)

There's no cable here. We have to drive 40 miles round trip to get the mail. (OTA096)

In the truck there I just had an ordinary antenna there until they went digital. Well, I just don't get it anymore. I don't even put the TV in the truck. (OTA083)

Where I am located there is no other option. We can't get cable. Cable doesn't come out to our area. We asked them numerous times if we got a number of people on the road but they said nope, that's as far as the cable goes and we're not going any further. -OTA088 
We don't have cable here. If we had cable here, we could get $\mathrm{CBC}$ but we don't have cable. I think the CBC's in a tough position. CBC's important to me. We don't have access to cable, full stop. So, we can't do that. -OTA092

\section{Internet and Mobile Availability}

Almost half (45 of 99) of the interviewed households reported attempting to watch $\mathrm{CBC} /$ Radio-Canada television programming online. The viewing of television programming via a broadband Internet connection and/or by way of mobile wireless service provider, a mode of post-analogue OTA television delivery much touted by CBC/Radio-Canada, was reported as a challenge for 30 of the households interviewed due to issues related to maintaining a steady video stream. Problems related to finding CBC/Radio-Canada television programs online were also reported by 14 households. As noted by OTA029, "I tried getting it on the net. I can't figure out how to get the news on the net. I typed in cbc.ca/news and all I get is all these subtitles for one thing or another". OTA025 noted, "My wife manages to get it on your laptop. She'll watch $\mathrm{CBC}[. \mathrm{ca}]$ extracts....We've tried a few times since to get the programs and haven't been able to", and OTA043 noted "Only way I can watch any television content is to bring it up in on my iMac... News clips through their news website or to actually watch parts of The National [via CBC.CA]. I haven't watched any other programs whatsoever" and OTA068 noted, "Now I watch a few specific shows on the Internet. I carefully select the shows that I want to watch and by that very fact it is hard to discover new shows".

OTA065 noted, "I watch reruns of the Rick Mercer Report on the Internet and that's about it" and OTA047 described a lack of program availability and computer hardware/software related barriers:

My laptop is from five years ago and hasn't got Flash player on it. Go through it (cbc.ca) like a TV schedule and pick what you want. Doc Zone is there but not Marketplace. There 
are a good many programs I used to enjoy that aren't there. Also, some of the special series that they put on. There's none of that.

Thirteen research participants were unclear what CBC/Radio-Canada television programming was available via live stream and how to find live streams. In one case, research participant OTA049 noted that he was unable to watch The National via live stream even though CBC Television has live streamed the program on a regular basis since 2007 (N. Makoway, personal communication, June 30, 2016). Research participants expressed frustration over which $\mathrm{CBC} /$ Radio-Canada television programs could be live streamed;

Can I get CBC live online? They were archival video clips, I think. I've been able to pick up some of those. Say, Rick Mercer Friday night at 7 o'clock. I don't know whether I can go online and pick up that show as I might from a television. Live streaming, that's what I'm talking about. It would certainly help if they live streamed it. Then I could get it from the Internet and watch it on my computer. The quality isn't as good. I would say. Some of this stuff comes through YouTube. If I can turn on my Internet and go to CBC at the same time, whether I can get it through the Internet, the same program, I don't know. (OTA064)

We watch live feeds for the shows that have it. They don't all do. Lots of them do. It's a diminished version of the CBC that we're getting now from the one that we used to get. I'll watch what I can drag off of the Internet. If CBC offers it I will watch it and if they don't I won't. If that's the way it's going to be and there's no other way to get it then I don't want the tax burden and the delivery cost. (OTA015)

I do not have regular access to CBC-TV, except by laptop computer usually 24 hours later than the regular broadcast. (OTA099)

It's pretty near impossible to get regular television on the computer. I have not been able to access CBC via the computer other than the free music channel. I've been suffering. I've been languishing without my fix of the night time 10 o'clock news and the regular CBC out of our provincial capital, St. John's. I'm missing some of their regular programming of entertainment offerings. Some good stuff there with 22 Minutes and some of the others on there. -OTA066

When we lost access to CBC I did try watching playbacks on the Internet but it's not the same thing. You're not part of the conversation. You can seldom watch the programs live. It takes a while to post it up. It also depends on how good your Internet access is. Like I say, we're fairly rural here. Sometimes you can stream it fairly nicely and that's fair enough but other times it's just not so good. -OTA092 
I think my wife has occasionally watched Coronation Street on the computer. They don't have live streaming. We can't get live streaming but occasionally she can sit down and watch it but she just doesn't like watching it on the computer. (OTA007)

As mentioned by OTA007 above, 14 research participants described ergonomic challenges related to watch $\mathrm{CBC} /$ Radio-Canada programs online,

The only thing I can do is watch the same programming online. I'm set up with the Internet. That's fine but it's not the same to sit down with your family and watch a television show as opposed to sitting around a laptop or whatever, little tiny screen, that people can't see at different angles. (OTA046)

In terms of reception on cell phones, I would ask her to watch a film with her whole family on her telephone. I am convinced she would give up. (OTA075)

While interviewed households that specifically noted seeking out Télévision de RadioCanada programming online did not explicitly mention "en direct" live streaming, four households reported viewing archived Radio-Canada television programming online via RadioCanada's streaming Video on Demand (SVOD) platform Tou.tv. OTA076 noted, "I watch certain shows when possible on the Internet at Tou.tv - but not very often" and OTA074 described viewing that was “Only by Internet connection so I don't have full access to all programmes, series, etc. I see French Radio-Canada television with my Internet connection.

Otherwise, mostly on Tou.tv". As OTA060 explained,

I did watch Tou.tv. They rebroadcast different programs. I watched a few broadcasts on my laptop linked with my Internet in this house. It was quite suitable. Sometime it stopped to get back to register the information and then it plays back for 10 to 15 seconds and then the broadcasts keep on... Broadcast that I missed that I really want to look at, then I can live with the regular stoppage.

This reported difference in online viewing of Télévision de Radio-Canada programming compared to online viewing of $\mathrm{CBC}$ Television programming may in part be attributed to the fact that Tou.tv was launched in January 2010 (CBC/Radio-Canada, 2017), more than 18 months 
prior the start of Canada's 2011 digital television transition and has proven popular with French language users.

While archival SVOD viewing of television programming online permits viewers to watch previously aired programming, at a time and place that suits them, live streaming of television programming aired by the public broadcasting is equally important. Radio-Canada has been a leader in this regard. Roughly $90 \%$ of Télévision de Radio-Canada's entire OTA broadcast day has been simultaneously live streamed via radio-canada.ca since February 2011 (CBC/Radio-Canada, 2014c). In sharp contrast, CBC Television live streams a very small portion of its regular OTA television broadcast day. While CBC Television's evening newscast The National, along with its regional supper-time television newscasts, have been live streamed online via its website since 2007, no other regularly-scheduled television programming was live streamed by CBC Television as of September 2016 apart from video feeds of regional radio morning shows, limited-time special event television programming such as the Olympics, and select limited-time television news items).

As noted earlier, 45 of the $99 \mathrm{CBC} /$ Radio-Canada television-viewing households interviwed that had been previously served by $\mathrm{CBC} /$ Radio-Canada analogue OTA signal(s) did attempt to access the public broadcaster's television programming online. However, 14 households advised that they had trouble figuring out how to go about finding the $\mathrm{CBC} /$ RadioCanada television programming online or if the same shows were even available online. Thirteen noted the lack of live stream programming and having to wait to watch the program via SVOD, in addition to problems with getting CBC/Radio-Canada programs to consistently stream to their computer so that they could be watched.

\section{3) Functionality}


I can watch it on the Internet but it's choppy. Very friggin' choppy. I can watch $\mathrm{CNN}$ better than I can watch CBC. (OTA002)

When households are connected to broadband Internet, and when CBC/Radio-Canada television programming is made available, online television viewing is possible as this 90 -yearold interviewee from Manitoba attests;

I watch whatever I can on the Internet. Live streaming. There must be more than I get but I don't bother. I really like the Internet. I prefer it to the TV, any day. This live steaming is wonderful. I watch The National and get it regularly. I get more off the radio. All I have is a computer. I sometimes watch sports, curling, figure skating. Sometimes I miss that. I have one or two occasion gone to somebody's place to catch a program but not very often. I get some of it on the Internet. Some of it is delaying a little but that doesn't bother me. OTA021

While OTA021's hunch was that there must have been additional CBC/Radio-Canada programming available for live streaming following the July 31, 2012 shutdown of CBC/RadioCanada's analogue OTA television transmitters/retransmitters, in terms of the regularly scheduled live streaming of CBC Television programming specifically, such online access as of August 1, 2012 was limited to The National, supper-hour newscasts, and Hockey Night in Canada (HNIC) (although HNIC live streaming of the 2012-2013 NHL season did not start until January 2013 due to a lockout) (CBC/Radio-Canada, 2013). This limited selection of CBC Television programs available for live streaming was further reduced by the start of the 20142015 NHL hockey season after CBC Television's broadcasts of $H N I C$ were no longer available for live web streaming via CBC.ca as Rogers retained such rights in accordance with its 12 year, \$5.23 billion broadcast deal with the NHL (National Hockey League, 2013, November 26). Live streaming of $H N I C$ games without a BDU subscription was thereafter restricted to viewing on mobile devices via CBC Television's Android and Apple CBC Sports apps. 
In contrast to CBC Television live streaming, as noted earlier, Télévision de RadioCanada has been live streaming approximately $90 \%$ of its regular OTA television broadcast day since February 2011 (CBC/Radio-Canada, 2014c). While it is possible that this incongruence in live streaming strategies between Télévision de Radio-Canada and CBC Television may be due to the fact that "CBC and its French arm, Radio-Canada, rarely connect" (Taras, 2015, p. 230) or that Télévision de Radio-Canada has "twice the audience share of its English-language counterpart" (Taras, 2015, p. 235), viewers of public television in Canada would be well served if CBC Television adopted the live streaming program delivery strategy of Télévision de RadioCanada.

\section{Mobile}

With regards to interviewed households watching CBC/Radio-Canada television services on a mobile device, while OTA080 positively reported "I can always have access to a lot of Radio-Canada content (radio, television, and internet) on my smartphone", as noted earlier 30 of the interviewed households advised that they either did not have a cell phone or they did not a cell phone capable of realistically providing their household with television:

My cell phone doesn't let me watch television. - OTA016

I shouldn't be obliged to one, buy a cell phone, because I don't own one. - OTA070 We what we do have is a $3 \mathrm{G}$ cell phone-like connection. That's how I receive the Internet. It's not great for watching video. - OTA071

My cell phone doesn't connect to the net, it's not a smartphone. It functions as a cell phone. - OTA085

I don't have a cell phone. I'm kind of an old timer, you know? I still play VCRs and stuff like that. I'm not for this new wave technology. - OTA053

I don't have a cell phone and I'm not much of an Internet browser. - OTA089

Internet and cell phone don't allow me to watch live in real time. -OTA067 
I live 100 yards off the major highway so cell service is pretty sketchy at times. I get, like, one (signal) bar. In order to get Internet on a cell service you need EV and the EV indicator very rarely lights up when I'm home. It does when I'm on the highway and in a major town. I live eight kilometers from Elm Creek and 10 kilometers from Common and I'm 100 yards off the highway so I'm right out in the boonies. I'm being facetious. I'm just saying that the coverage for both digital signals both cellular and digital TV suck! OTA037

As far as getting on the cell phone, my cell phone doesn't work here in the house because of location. I have to go half a kilometer up the road before I can receive anything so I'm out of luck that way as well. -OTA027

Mobile telephones here are not capable of doing most of the functions that they're capable of doing in the South. We don't actually use mobile telephones, cellular telephones or smart phones. In a lot of cases we're using Iridium satellite telephones because there is no cell coverage here. - OTA059

I do have a laptop and I have an iPhone that acts like a transmitter. I have been able to watch very limited amount of television. It kind of stalls. I have to have a lot of patience to watch anything... My son said I could do it overnight, a torrent. But the whole idea of a television is to flick it on. Oh, the news is on, let's watch it. Oh I've got to plug the news in...I'm not even sure what to do it. I have unlimited data. It takes a lot longer to watch a 20 minute show because it's stalling. - OTA062

I don't know if you've ever been to the boonies of Ontario but we don't have high streaming capabilities on our Internet either. Everything takes a really long time to download and all that kind of stuff so that's inconvenient. The scrubbing is really slow where we are. I'm hooked into the cellular network, even my Internet for my computer is cellular. It's not very fast Internet. It would be just a game of frustration for me. Internet, ya sure, but that's a bit different because you have to go looking, right? You have to go find the show you want. - OTA084

\section{Internet}

While reliable viewing of $\mathrm{CBC} /$ Radio-Canada television on a cell phone appeared to be a distant dream for 30 of the households interviewed, as noted earlier 74 of research participants interviewed did indicate that they had Internet access. However, participants such as OTA040 noted, "I haven't got a computer so I can't see it over the computer", OTA057 noted "I don't have a computer", and OTA053 noted "I don't have Internet".

An Internet access issue for 22 research participants interviewed dealt with a lack of an Internet connection that provided a sufficiently high-speed connection to the home. For OTA018, 
"Our computer is dial up. That's not an option", OTA071 noted "We don't have high-speed here" and OTA078 stated that "High-speed Internet is not possible". As OTA056 noted, "You can try the Internet but we only have dial-up Internet service here so it takes a long time to connect and it's quite erratic".

For OTA024, while online viewing of $\mathrm{CBC} /$ Radio-Canada television was possible in the household it was far from smooth:

I watch tiny snippets via Internet except another rural issue is that I have very very slow Internet and there is no high speed Internet available out here where I live. The Internet bandwidth is lamentably, pathetically, laughably, slow so that's not an option. Even if I were to get a satellite I would with luck get a download speed of between three and four Mbps which doesn't qualify as high speed. I wish I had other media. Until relatively high speed becomes available, without vicious caps in terms of bandwidth, I really don't have any option whatsoever where very much CBC Television is concerned. - OTA024

As illustrated above, while 77 of the households interviewed for this dissertation did not report Internet speed connection problems, and 45 households had indeed at least attempted to watch $\mathrm{CBC}$ and/or Radio-Canada television programming via the Internet, online functionality was lacking in terms of their ability to replicate the level of access to the public broadcaster's television programming as had been previously provided by their now missing over-the-air $\mathrm{CBC} /$ Radio-Canada television signal(s). On the topic of broadband Internet penetration as a measure of access to communications, Reza Rajabiun and Catherine Middleton (2015) note that, Although penetration rates may have been a good indicator of market outcomes in the transition from dial-up to broadband, the actual quality of service end users achieve represents a more realistic indicator for measuring the pace of progress in the diffusion of next generation platform technologies. (p. 231)

In terms of the quality of broadband Internet service as experienced by end users, the following households interviewed described challenges related to their ability to watch $\mathrm{CBC} /$ Radio-Canada via the Internet when compared to their previous OTA television viewing; 
CBC's remarks were really nice. They said, 'well, use the Internet'. We only just got highspeed Internet a little over a year ago. It's only 1.5 megabit download speed so it works but doesn't work. It's pretty jerky. A lot of buffering. - OTA011

Impossible to download SRC or CBC TV over the web at the 'choked' bandwidth which Northwestel gives Whitehorse. I have never been able to watch over the Internet successfully a CBC television news clip of even one minute duration over the Internet line that we now have to South. - OTA059

Watching it over the Internet, our high speed isn't really high speed. It doesn't come in clearly. It slows down. We watch some things on the Internet but it goes and stops while it tries to catch up and then we miss things on it. It's not a continuous feed. It's not really in the books for us. - OTA027

Sorta, half-high-speed. It’s not great. Rural-Nova-Scotia-Medium speed. - OTA058

Occasionally I will watch video coverage on my computer through my high-speed Internet but I have to choose times for that because the streaming is not constant. There's a lot of re-buffering so I don't do that very much either. I don't have time to watch an hour long show that takes an hour and 45 minutes to see the whole thing because it's buffering the whole time. -OTA031.

You can't get Internet that is reliable enough to watch video on it. It's an overloaded system and it's as slow as cold molasses and it just isn't practical. It's impossible to watch. - OTA008

If you're going on the Internet to watch it, if you want to watch it at a time when the network is not congested, you can do that. It's shifted to a time that's not as convenient to you. - OTA006

I was having trouble even getting $\mathrm{CBC}$ to play online if I wanted to get $\mathrm{CBC}$ 's version of the news. Now I've changed to what the provider calls WiMax and we're no longer on the same antenna as people who use and download Netflix. Now I'm able to listen and watch $\mathrm{CBC}$ online without constant buffering. Whatever they (CBC) offer online I can get. It's not the same programming but at least I can get some of the $\mathrm{CBC}$ television stuff like The National. It's still not the same as having the same full range of television shows OTA010

I do have satellite Internet. It's not very fast so any kind of videos don't work and I can't watch a movie because in order to get fast enough Internet service on satellite you have to pay about $\$ 150$ per month. Mine is $\$ 60$, so it's midway. I can't really watch TV on the Internet either. We're exasperated. It's not the $\mathrm{CBC}$ we knew. I can't watch it on the Internet because my Internet service is too slow. It's satellite. Plus, if the wind blows the wrong way, or three sprinkles of rain, that's done for a half-hour or an hour and sometimes all night. -OTA014 
Watching it on Internet is not an option because my Internet service is by microwave tower and it's simply not fast enough. - OTA030

We only just recently were able to get highspeed Internet access in our area and it's still pretty sluggish. Even when I try to access CBC over the computer we often times don't have a signal that can accommodate it. Depending on the evening we may or may not get the signal. - OTA032

We're down a little bit of a valley. As far as Internet goes or Satellite Internet, we can't pick up anything from any tower. -OTA061

After CBC went digital I wondered if I could pick it up over the Internet. As it turns out, with the equipment that I've got, I can't. My Internet connection is not fast enough to stream video. I can't watch it over the Internet because I'm rural. That's not an option for me. - OTA073

We have moderate speed [Internet]. We have a wireless system that currently operates at up to 4 mbps so it can do reasonable video but sometimes weather affects that. I think it's just not as solid as something like cable or certainly over-the-air broadcasting typically. OTA085

We've had a real struggle with it (Internet). It goes out for days at a time. It's very frustrating. We're getting something like $.3, .4$ megs. It's not fast enough to bring in things like YouTube or anything. It's a little better than my dial up, what can I say? Keep my dial up too so that I have something when my Internet goes down, which it always does. So that's where we are with Internet service here... We don't have enough speed to bring in anything. I can bring in news articles, just text. It (CBC website) stalls all the time. It takes forever to load and it stalls constantly. It's very frustrating. It takes you a long time at .,3 megs. It's very frustrating. (Laughter). We're cut off. What can I say? - OTA096

As a side note of value discussed next, five households interviewed reported success accessing CBC/Radio-Canada programming OTA care of CBC/Radio-Canada privately-owned affiliate stations that were still operational following the shutdown of CBC/Radio-Canada's own analogue television transmitters.

\section{Access provided by privately-owned OTA CBC/Radio-Canada Affiliated Stations}

While CBC/Radio-Canada's last remaining CBC Television private affiliate station CKSA-DT in Lloydminster disaffiliated from the public broadcaster effective August 31, 2016 (CRTC, 2016d), leaving two Télévision de Radio-Canada private affiliates in Quebéc as the only remaining $\mathrm{CBC} /$ Radio-Canada affiliated television stations, five research participants 
interviewed for this dissertation noted that $\mathrm{CBC} /$ Radio-Canada affiliates played a role in

providing access to $\mathrm{CBC} /$ Radio-Canada television following the public broadcaster's 2011-

2012 shutdown of its analogue OTA television transmitters:

Kingston is still on analogue. From where I am, Ottawa is where I relate to rather than Kingston, Kingston being smaller. Before, I was able to get the one from Kingston, the affiliate, and CBC from Ottawa. - OTA050

In the analogue age, I regularly watched CBC Ottawa, Channel 4, and $\mathrm{CBC}$ affiliate Channel 11, Kingston. When Channel 4 switched to digital transmission, I lost that signal and that is the case today. Channel 11 went digital last summer and I still receive that signal. Therefore, I currently can watch only the one CBC (affiliate) TV station. Overall, I wish the switch from analogue to digital hadn't occurred. - OTA023

We can get Peterborough, CHEX TV, which is an affiliate of CBC. Not very well but we can get it sometimes. It doesn't carry all the CBC programming but we can get it a little bit. That's how we get it now. It's not what it was. It doesn't have the same programming plus we don't get it at the same quality, the same strength of station. Sometimes we get it and sometimes we don't just because of our location. The signal isn't as strong so sometimes we're not really able to view it very well. - OTA027

When we do scans we're not picking up anything from Radio-Canada. CBC, we still get CKWS, Channel 11, Kingston local station. But we find now that, we don't know if it's due to the switch to digital, but the picture's cut off. We'll be watching The National at night and you'll only get half of the person that's talking, name and stuff. We don't know if that's because of that. There was once since the switch over that I actually got Ottawa CBC (OTA digital) which was exciting but then it disappeared by the afternoon. It probably lasted a couple of hours. We're still getting it (CBC) the old fashioned way, via the CKWS affiliate. Radio-Canada, it's sorta sad we don't get because the kids are in French Immersion. -OTA054

In one instance, OTA061 was able to continue to access CBC Television programming OTA in analogue after CBC/Radio-Canada shut down its analogue transmitters, care of $\mathrm{CBC}$ Television affiliate CHEX, but eventually lost OTA access once CHEX converted its OTA transmitters to digital OTA in 2013.

As outlined above, $\mathrm{CBC} /$ Radio-Canada affiliate stations helped bring $\mathrm{CBC} /$ Radio-Canada television programming to five households interviewed following the shutdown of their nearest 
$\mathrm{CBC} /$ Radio-Canada owned transmitter(s). This fact points to the role that $\mathrm{CBC} /$ Radio-Canada affiliates played in serving the public interest in terms of providing access to the public broadcaster's television programming. The benefit of expanded access to CBC/Radio-Canada television programming experienced by households in 2011-2012 was the very reason why the use of privately owned CBC/Radio-Canada affiliates were originally approved back in 1952 . As the household interviews conducted for this dissertation help to illustrate, local privately-owned CBC/Radio-Canada affiliates continued to serve a role in providing access to CBC/RadioCanada television programming following the public broadcaster's truncation of its OTA television network in 2012.

While CBC/Radio-Canada's website continued as of September 2016 to incorrectly list former privately-owned CBC/Radio-Canada affiliate OTA stations as still offering access to CBC/Radio-Canada television programming over-the-air even though many ceased to be affiliates years ago (CBC/Radio-Canada, 2012), it is important to note that the disaffiliation of such privately-owned stations has been at the behest of CBC/Radio-Canada. Although CBC/Radio-Canada's original plan to move away from the use of private affiliates was originally tied to a plan for CBC/Radio-Canada to instead purchase such affiliates, and for the Crown Corporation to operate the transmitters themselves, around the time of Canada's digital television transition the public broadcaster's plan switched such that while it continued to move forward with ending $\mathrm{CBC} /$ Radio-Canada affiliations with private stations it declined to purchase them as originally planned. This left former privately-owned CBC/Radio-Canada affiliates to seek alternative sources of non-CBC/Radio-Canada programming, and left OTA CBC/Radio-Canada television viewing households that had been relying on such affiliates for access to $\mathrm{CBC} / \mathrm{Radio}-$ Canada programming without OTA access. This change in citizen access to CBC/Radio-Canada 
television programming fits with the public broadcaster's trend of stepping away from its obligation to make its television programming accessible to Canadians via its own transmitters and to instead rely on privately-owned BDUs, ISPs, and mobile wireless service providers to help pick up the slack in its mandated public television delivery service obligations.

Importantly, the CRTC reiterated in its August 2016 decision approving Lloydminster, AB CKSA's disaffiliation from CBC Television what it had previously stated in June 2014 when it approved the disaffiliation of Thunder Bay Electronics Limited's Thunder Bay, ON CKPR-DT (Broadcasting Decision CRTC 2014-316), in August 2015 when it approved the disaffiliation of Corus Entertainment's Peterborough, ON CHEX-DT and Brighton, ON CKWS-DT (Broadcasting Decision CRTC 2015-403) and in February 2016 when it approved the disaffiliation of Bell owned Terrace, BC's CFTK-TV and Dawson Creek, BC's CJDC-TV from CBC Television (Broadcasting Decision CRTC 2016-63 and Broadcasting Decision CRTC 2016-62) that "[t]he Commission considers that the responsibility to provide the CBC's services rests with the CBC, not with private broadcasters" (CRTC, 2016-322). While the CRTC also notes in the decision that $\mathrm{CBC}$ 's programming will still be available to the surrounding area via cable and satellite subscription, BDU delivery of the public broadcaster's television programming is not without its barriers to access. That the CRTC would state in the noted decisions that it is not the responsibility of private OTA broadcasters to provide CBC services, and then imply (accurately) that private BDUs do have such a responsibility, illustrates how the Commission continues to rely on private BDUs to support the ends of Canada's regulated television television system in terms of the provision of access to $\mathrm{CBC} /$ Radio-Canada television programming. Most revealingly, the CRTC explicitly states in its recent disaffiliation decisions that "the responsibility to provide the $\mathrm{CBC}$ 's services rests with the $\mathrm{CBC}$ ". $\mathrm{CBC} /$ Radio-Canada 
itself then has a responsibility to provide household access to its programming, by OTA or by other means. Thus, for those Canadian households that lost access to the public broadcaster's television services following the shutdown of its analogue OTA television service, and that were unable to regain access as a result of barriers related to BDU delivery, the ultimate responsibility for providing such access falls to CBC/Radio-Canada. In other words, the CRTC has confirmed that it is $\mathrm{CBC} /$ Radio-Canada's responsibility to provide access to Canadian households that have lost access to its television programming.

\section{4) A la carte}

I say, hey, how about just CBC Winnipeg? That's fine for me. (OTA020)

Eleven interviewed households advised that they were no longer able to maintain à la carte access to $\mathrm{CBC} /$ Radio-Canada television programming following the shutdown of the public broadcaster's analogue OTA television service. OTA086 noted, “I don't want to get cable or satellite and have to get 20 channels when all I want is one or two at the most. I'm not sure what I'm going to do. Maybe nothing", OTA034 stated, "I do not want cable, I do not want access to American programming. We're probably going to end up with the cheapest version of cable you can get, I guess. Why can't I just have CBC and nothing else?", and OTA086 advised, "I don't want to get cable. Maybe you could have a cable with only CBC? And only pay accordingly? Instead of paying $\$ 60$ a month for 20 channels you don't want. That's what I think they should have done". As noted by OTA072, "I'm not in a position to afford that [satellite] nor do I really want all the crap that comes with it just so I can have CBC or pick and choose".

As put by OTA034, "I'm not upset at CBC at all. I'm really upset with the federal government and their treatment of $\mathrm{CBC}$ in general. I just really wish that I could get just $\mathrm{CBC}$ 
and to hell with all the other networks and all the other shows. I know that's no longer possible and I'm just going to have to suck it up". OTA036 succinctly summarized the situation as such,

When you get a satellite dish or cable, the CRTC, although they're talking about changing it, you have to get a bunch of programming that you don't want. If I want to pay for CBC Television, and I want to pay for two or three other channels, I don't want to have to pay for 50 other channels too. I don't want to get a satellite dish because I don't want to pay for programming I'm not going to look at. I want to be able to select the channels I want to pay for. CRTC is supposed to be going to give you more choice. You'll pay more for your individual networks but supposedly you'll pay less over all unless you still want 200 different networks.

\section{Local Television Satellite Solution (LTSS)}

The closest that interviewed households could get to à la carte access to $\mathrm{CBC} /$ RadioCanada television service(s), post-analogue OTA, was via a no-fee basic satellite DTH television service offered by Shaw Communications named the Local Television Satellite Solution (LTSS). As part of a $\$ 180.1$ million tangible benefits package tied to the CRTC approval of Shaw's purchase of CanWest Global Television in 2010, Shaw committed to spend $\$ 15$ million on providing a no-fee DTH satellite television service for the 31,500 households that were anticipated to lose OTA television access as a result of Canada's 2011 digital television transition (CRTC, 2010c).

Under the LTSS, eligible applicants would receive one satellite receiver, one satellite dish, no fee installation, and a basic television package of roughly a dozen television stations as determined by Shaw. While households participating in the Shaw LTSS program were technically Shaw Direct subscribers, and had to sign a special LTSS contract, the regained access to conventional OTA television stations (including CBC/Radio-Canada) provided by the LTSS program required no fees. While Shaw's LTSS is not a true à la carte service since households were given additional channels in addition to at least one $\mathrm{CBC}$ Television station and one Télévision de Radio-Canada station, the LTSS program approved in 2010 by the CRTC (paid for 
and administered entirely by Shaw) was in many ways a precursor to the CRTC's 2016

affordable basic package BDU regulations. The CRTC-approved LTSS is arguably still better than the CRTC-mandated affordable basic package however, even though the LTSS offers less channels than the 'Skinny Basic' packages offered by BDUs in 2016, since the LTSS does not require households to pay any subscription fees.

Twenty-one of the previously analogue OTA CBC/Radio-Canada television-viewing households interviewed for this dissertation advised that they regained access to the public broadcaster care of the LTSS program. However, for the households that were able to regain access to the public broadcaster via the LTSS, there was confusion with respect to who exactly was sponsoring the service and for how long the service would be available for:

I have received the Shaw program set up by Harper and now receive 13 channels. LTSS was not mentioned to me until I complained. It wasn't the first thing that came off their list of things. My friend came over here today to get me to, 'cause he can't get it either, and he doesn't have a scanner, so he had me scan the LTSS form for him and wanted me to send it but I guess my computer is already registered as sending one so it wouldn't allow me to send his even on his e-mail...I am happy with this program offered by the government, but am concerned that with them taking down the original repeater towers. - OTA038

We now have CBC via a Shaw satellite dish which was provided free of charge. By Shaw? CBC? The Harper Government? Originally, we had multiple CBCs, but they did something and now we have CBC Vancouver. One of my sons who's really tech savvy and is always looking at things on the Internet told us about this program with Shaw. If you phone this number, went on this website, contacted Shaw and they would send this mysterious black box. So my wife did that and a month or so later the box came. And she spent a lot of time on the phone with Shaw and then arranged for someone to come and install it and this morning a couple of folks were on the roof putting a dish up. There is no charge for this evidently but it's a pretty well-kept secret. Now she gets a dozen channels including CBC and there's no charge... CBC Vancouver, CBC Dawson Creek and CBC Yellowknife. I look at the CBC website but I didn't ever find anything useful. It was one of my sons who found this link that would connect us with Shaw. It was my son who found this link to Shaw Television. When my wife contacted Shaw they told her there would be a month delay because the demand for these converters was far greater that they anticipated. OTA070

I have in fact regained access to CBC-TV. I found out about Shaw offering a free service to replace those of us who were losing OTA television. It is what they called LTSS: Local 
Television Satellite Solution and what I'm hoping will also be Long Term Satellite Solution. Basically, before the end of November 2012 I had to contact a special toll free number, give them my name and details and they send out an installer to assess your location and if possible, do an installation. Installation was successful and I'm able to watch CBC TV again. I did regain the station I had lost, which was CBC Toronto. In fact, I also regained access to TVO, as well as access to several other stations I was not able to receive before. Well, they better not start charging. But they do phone me regularly trying to get me to upgrade. I have asked them to please stop. I am a person with a congenital disorder and living on a fixed income. -OTA071

Some time ago Shaw Direct came out with a package of about seven stations which included CBC. This offer was free although I have had a few calls of more stations for a price, which I declined. As I told them $\mathrm{CBC}$ was what I wanted and I am quite satisfied with that. As I understand it, it was cheaper to give the few who had peasant TV this offer than upgrade the towers to reach those few who only had the two stations...As far as I understand, it is that CRTC is responsible for these transmitters, at least that's what the guy who installed our dish told us. He said the CRTC was backing this free program because they didn't want to have to highly upgrade the transmitters that they had left. I'm not blaming $\mathrm{CBC}$ at all. -OTA095

Somewhere in [a] conversation (with a CBC person) I made the comment, "well, now that I don't have any TV...' and she said, 'well, you know you can get this Shaw thing' and I said 'oh, I didn't know that was for Whitehorse' and she said, 'oh, ya you have to sign up for it by the end of November'. That was first I realized I had access to this. I told my neighbour about it, she doesn't have cable either, she hadn't heard about it and so on and so forth. I know this Shaw thing is just a gimmick to get, in five years when they turn it off, is that I'm going to go buy it. I phoned CBC and got the Shaw number. - OTA094

Even though the program with Shaw's free, we did have to spend a little bit because where we wanted to put the dish we had to put a post in the ground and that sort of thing. We have regained access to CBC-TV. Through the Local TV Satellite replacement program we got a satellite dish with the local channels for free. It was through Shaw last Fall. So we have had the service for about a year. Several other friends in Whitehorse went with the same option. Previously, CBC came from Vancouver and we still have access to that channel, as well as a couple of other BC channel. I think they still carry the North Beat weekday news cast. That's the only northern programming. -OTA087

I heard about this offer from Shaw. Recently we've just gotten a promotion from Shaw. It was a free dish and free receiver with nine channels so we do get $\mathrm{CBC}$ again now. We had Ottawa and now we have Toronto. We live two hours from Ottawa but four hours from Toronto. We weren't served at all because CBC didn't really have anything to do with the TV we have now. My husband would rather get Ottawa because it's local weather as opposed to just a little blurb about our area when it comes to the weather report. I guess it would make more sense to have your local station, really, because you're getting the news from there but Toronto has way more interesting news anyway, lots more fires and murders and stuff. Shaw offered us a free satellite dish with nine channels. We used to get it from 
Ottawa (our local) and I'm not sure where it's from now. My husband informed me it's CBC Toronto. We don't mind getting Toronto news as we lived there for years and as my husband says, it's more exciting news anyways! The programming is comparable if not the same. -OTA084

\section{Non-LTSS BDU}

Eighteen previously-analogue OTA CBC/Radio-Canada television-viewing households interviewed for this dissertation subscribed to a paid BDU service in order to regain access to CBC/Radio-Canada television programming ):

I decided to go to Bell ExpressVu but I have to pay for that so I have to have satellite. OTA017

We have access to CBC Services via Bell Satellite. We get multiple CBC "channels" but mainly watch the Halifax feed. After we subscribed to Bell TV we found out that Shaw was re-offering a "free" four channel service for people who had lost service due to the conversion to digital many of my neighbours took advantage of this. Unfortunately, I'd been told we didn't qualify when this was first offered. Shaw at one point was offering a low cost, four channel option if qualified. I phoned about that and because of the Middleton transmitter, which we couldn't receive, that we weren't eligible for the satellite service. Now, I guess that all would have changed with Middleton being shut down as well as the St. John feed for the CBC. Prior to that I had gone to a Bell satellite system. OTA011

We now receive TV via satellite and the service is provided by Telus. We do receive some added programming like sports, National Geographic, and Animal Kingdom, etc. But we pay a price for that. We still watch CBC the most, and CTV is our second choice. We use to watch $\mathrm{CBC}$ Edmonton and continue to do so. That has not changed. The difference is that we now pay a satellite server fee. -OTA026

We have it on a (Bell) satellite. We do have an antenna as well so that when the satellite goes off we're able to get it on antenna except this year when they cut us off. -OTA091

I'm going to have to get a satellite which I'm not happy about because then I don't get my local television. I thought it was a citizen's right to have access to Canadian national news which I guess I sort of have through CTV which I can get through my digital box. I've always been a CBC watcher. -OTA019

We did phone into CBC to complain. They told us to call Shaw Direct which we did. It's time consuming. Even though we have satellite and a receiver that works they won't accept it. We have to bill the government I guess to send out a new one. Waste of our tax dollars when I've got one here. We just have to wait for that to be replaced. The thing is, I'm not sure if we're still going to be able to get local. I don't know if it's national or if we're still going to be able to access local. - OTA042 
My wife heard something on the radio about a dish being made available to people who lost the signal here. People who were not on cable and had no other means. They were going to supply a dish that would receive it but be Montreal CBMT and Radio-Canada. They asked her what we had and she said we had an outdoor antenna. Those are the only people who asked about it. All those who had lost service would be provided I assume a satellite dish for receiving $\mathrm{CBC}$ and Radio-Canada. It was on $\mathrm{CBC}$ radio that they heard it. She called them and they called back. There's no way I can get it unless I get cable or Shaw provides a dish. We don't get cable out in the country. -OTA048

I called Bell Canada around the middle of October (last year) and I didn't really like it but I didn't have a choice. I lost all my channels. They came around the middle of October. So that's when I called them (CBC) up. They looked at the map, what region I was in and they found out that yes, I will be losing it. I waited until the last day. I always got cold feet. I said nope I got four [OTA] channels. I'm happy with my four channels, I'm keeping them. I never got a satellite. When I lost all my channels and I couldn't watch Dragons' Den and stuff like that I was kind of very upset, you know? I had no choice. La Facture. I'm French by birth and I speak a lot of French sometimes. Especially around Christmas time there's a lot of good Christmas specials that I didn't want to miss. I got a satellite dish but it wasn't what I wanted. I wish I could scrap it. I wish I could tell them, here come get it, you know? I heard they might go back to analogue. What do you think? I hope they do. I could scrap the satellite dish and go back to what I had before. I was happy with what I had before. -OTA053

APTN was offering a free set up for people in certain communities who could not get digital once they went all digital. I didn't qualify because I'm in a community called Happy Valley Goose Bay that has cable. But I don't actually live in the community and I explained that to them. I'm in a cabin so therefore I should have qualified but they said no so I lost APTN a few months back. APTN and CBC only stations. Nuttin' honey. I don't know. I'm not even sure if we can go get satellite TV and buy that big package and get CBC that way. I don't know if I can afford it. -OTA014

I got a little bit about the Shaw information. It was sort of being shared around town. Our local CBC radio did give us a 1888 number to call. I think it was CBC's attempt to help. I called that and I got no satisfactory advice of anything...I applied to Shaw on September the 21st. They sent me an application back, I filled it out and a month later I received their Shaw receiver. I was told I could make an appointment with the installer guy. He came. He assessed my house. Within 10 or 15 minutes he said I cannot guarantee you a good signal. The reason is that I am absolutely at sea level and he said the new Shaw satellite that he would be using and tuning into is right on the lower horizon. He said in addition to the trees and any obstructions this satellite is extremely low and difficult for you to reach from this location. It was also cold, slippy, icy weather at the time when he finally came, it was November I think...He then suggested that if I wished to bring up my Bell receiver from the remote location he would come back and he would install the Bell receiver as a friendly gesture, nothing to do with Shaw at all, and he would charge \$50 dollars. I said I would consider it once the weather improves and the bad winter weather is gone. If I got the dish 
and lined it up with the Bell satellite, the Bell satellite is higher... I'm getting a bit long in the tooth and it's a big hassle. I'm reaching my technical limit here. - OTA099

Because CBC wasn't included in the basic package we had to get a [satellite] package (from Shaw) that costs us $\$ 80$ a month and CBC is the only channel that I watch. Come the spring when the leaves are on the trees we could no longer receive that. In summer I can't get $\mathrm{CBC}$ at all. In fact, we've only just got the signal back. (Satellite was) the only way we could get $\mathrm{CBC}$...We had to sign up to a package that included local CBC and that costs us $\$ 80$ a month. CBC is the only channel I watch, full stop. You want to know what's going on locally. My neighbour at the end of the road, we were watching the NHL playoffs that was it, and half way through the transmission the signal cut out. They're on satellite as well. The other thing you get if you're using satellite as well of course, if you get heavy rain you lose the signal. Anyone on satellite knows that that's an issue. We do access via satellite but as I say because local CBC isn't included in basic packages, it's costing us $\$ 80$ a month and CBC is the only station I watch. When we lost access to CBC I did try watching playbacks on the Internet but it's not the same thing. One of the things they could do is make sure all the providers include their local $\mathrm{CBC}$ channel in their base package. OTA092

Our neighbours found out that Rogers Cable is offering a free satellite dish or something like that for the first five years. One of the packages will be $\mathrm{CBC}$ but it's a private service and eventually they will have to pay. On principle I'm not happy with the idea of having to work through a private company to access a public broadcaster. I'm not pleased about that. Even if it is free for the first five years I'm not sure that we want to do that. The CBC, we've lost it. - OTA033

Those of Aboriginal descent and in remote aboriginal communities would be able to get $\mathrm{CBC}$ with the aid of a digital converter or something like that. Maybe it was a dish or something they were going to be supplied with. I had no recourse to that. I'm not Aboriginal myself. I can't afford to get cable or satellite. I don't want to get cable or satellite. I'm not going to get cable or satellite just to watch CBC. I guess I'll just have to rely on radio and my ability to make pictures in my head without actually having the television supply that for me. -OTA066

Six of the18 households interviewed that subscribed to a BDU service entered into standard Shaw Direct rather than Shaw's no-fee LTSS option by Shaw:

I regained access to CBC TV by subscribing to Shaw Direct for about $\$ 35$ per month. This is the cheapest package we were able to get. - OTA051

We do have access now to CBC and CTV local because we gave in and purchased a satellite dish and a contract (with Shaw). The cost is about $\$ 60$ dollars a month and we don't watch much TV but that was the only option to have any news coming in aside from radio. -OTA004 
I had to call a technician that sold me a satellite dish. The new technology has regular broadcast failures. As soon as there are strong winds, thunderstorms or snow fall, the signal pixels freeze on and off or there is a complete failure of the transmission. Failures vary from a few minutes to several hours I am very unsatisfied with this technological development. -OTA075

Right now I have this Shaw cross country satellite TV. To get always any channel now you need to get satellite or cable television. I had that but at the same time when I go to my bedroom then I don't have that hook up then I could still receive CBC but now I won't be able to do that. How it affects viewers is not explicit. There's also negative side. Negative side means you affect people, the viewers. Homes that don't subscribe to commercial providers then won't be able to receive the CBC. -OTA069

Because CBC wasn't included in the basic package we had to get a [satellite] package [from Shaw] that costs us $\$ 80$ a month and $\mathrm{CBC}$ is the only channel that I watch. OTA092

After years of using an antenna, we opted for the only alternative: Shaw Direct with a dish. - OTA078

For households that did sign up for Shaw's LTSS program, three cited pressure from

Shaw to sign up for a paid satellite service:

We contacted the Shaw program to supply a dish and some channels, and this [LTSS] service began in the Fall of 2012.... Shaw keeps sending me flyers about the wonderful services that I could purchase from them. I've also got several phone calls from them. One time I said I didn't want the 100 plus channels they were offering because I'd never be able to watch them all- and the caller said "But you don't need to watch them all at once!". I responded that I did not need to have that many choices. A local business installed the satellite for Shaw, however only placed it about five feet up on the trunk of a nearby tree. There are occasionally reception problems related to rain/ice/snow coverage. -OTA016

I was/am a recipient of the Shaw LTSS service, so now get CBC on a few TV channels...(Same $\mathrm{CBC}$ as before). I do get calls wanting me to "upgrade" which I decline. In the future, I'm sure Shaw could introduce payments, but as of yet have not heard anything. CBC is a necessity for me, so if I was forced to pay, I probably would, as long as I could get $\mathrm{CBC}$ without a lot of the garbage channels. I have now applied through the program through the Federal Government through Shaw Direct to get a free satellite dish received that will then allow me to get $\mathrm{CBC}$ TV and a handful of other channels. One of the individuals from CBC had contacted me and made me aware that this (LTSS) program was available. That has come to my attention. I've got the order placed and just waiting for the installation and everything to happen now as my solution. (In BC) they had (hand-made) posters up in their general store walls saying this is the details how to do this. I'm can't recall seeing any here in Whitehorse. It came to me via e-mail by a CBC staff member. There is an option, it's a viable option, it's just does everybody know about it. On 
the outside wall there is a bulletin board and it was just tacked up. Who put it up I don't know. It was on an $8 \times 11$ paper that somebody had typed out. I don't recall any logos on it. -OTA055

Now we are hooked to the LTSS program... . After five years I understand I'll have to buy a package from Shaw Direct and I don't really want a package. All I really want is CBC. OTA088

\section{5) Locally relevant feed(s)}

Fortunately, we were able to get a minimum number of channels given to us by Shaw satellite and I've been able to pick up Toronto CBC which is good because at least you get some world news. I still don't get any Ottawa news though and that really disappoints me because Ottawa is really our closest centre right now. (OTA056)

A lack of access to locally relevant CBC/Radio-Canada television feed(s) that they previously received via analogue OTA was also cited by five households as an issue. OTA075 noted "it's very expensive for a basic service with access to Radio-Canada's national network and not to our regional station in Sherbrooke" and OTA075 noted "I had to buy a decoder, the reception was so bad, that after two weeks, I had to call a technician that sold me a satellite dish. Now I no longer receive the local station, but only Radio-Canada Montréal”.

A specific Shaw LTSS television delivery issue was reported by three households located in the province of Newfoundland and Labrador in relation to access to locally relevant CBC Television. The following interviews with Shaw LTSS program subscribers from that province reveal a post-analogue OTA television delivery problem that $\mathrm{CBC} /$ Radio-Canada, Shaw, and the CRTC apparently did not anticipate:

I sent (the Shaw) application in. There's no Newfoundland TV on it. All I have for Newfoundland TV is Here and Now which is 5:30 to 7 each night. If you don't happen to be there from 5:30 to 7 pm you don't get any Newfoundland content. If I paid a whole bunch of money for satellite I'm sure I could get it but I don't have that kind of income. The channels they are giving are Halifax and NB in French. I heard (about) it (the LTSS) on CBC Radio. Then when they sent the papers over I realized it was really true. I think 
it's really insulting that's all we get (5:30 to 7). I have a digital High Definition TV and I bought a new set of rabbit ears thinking that rabbit ears could pick up digital signals and I thought that would be all that I needed. There's only one transmitter in the whole province. Taken away what we have and I don't even think that's legal under the CRTC. Now we can't even see what's going on in our province. I think it's a disaster. I really fear for the country now. -OTA047

Shaw carries our satellite signal and they just don't provide for local programming. Every other station in the country, as I understand, Shaw carries with the exception of CBC Newfoundland. There's nothing I can do. There just isn't any. I suppose I could get cable but I'm in an area that's hard to get cable. You have to pay a premium. One of thing that they could have done is the same thing they do in every other city that I can see. You can get CBC from Halifax or Ottawa of Toronto right across the country, to BC on satellite. Channel 299. But with the exception of St. John's, except for one hour a day, 5:30 to $7 \mathrm{pm}$. An hour and a half a day. We can get the news if they (Shaw) remember to switch over. Sometimes they just continue with their own promotional program on that channel. I think if they gave us a dedicated CBC St. John's channel on satellite it would help me. I don't get out anymore because I'm bedridden. Satellite, it's the most atrocious way of watching TV because when it rains, when it snows, even when the wind blows hard you lose the signal. Fog affects the signal. A good part of the time you've got no TV at all. - OTA008

I actually did a little of research on it and found that Shaw has been given some funding. I think from the Federal Government for anyone who has lost their TV reception can get a dish from them that will bring them $\mathrm{CBC}$ again for free. I received their little package in the mail and I can't get CBC St. John's. I can only get CBC Halifax which would not give me my local news. That's a bit of a downer. CBC to me, as a Newfoundlander, is the only thing that makes me feel like I'm a part of Canada...I have very recently gone ahead with the free program from Shaw where I get a satellite dish to feed me CBC from Halifax. So I don't get my local St. John's newscast, but my husband gets to watch Hockey Night in Canada without the bothersome Internet stalls. - OTA046

\section{Summary}

Over $80 \%$ of CBC/Radio-Canada's OTA television-viewing households interviewed for this dissertation advised that $\mathrm{CBC} /$ Radio-Canada's switch to 27 digital OTA television transmitters had resulted in a delivery scenario that was going to cost the household higher television access fees, one way or another, if the household opted to regain access by means other than OTA television. A third of households argued that they had already paid for their $\mathrm{CBC} /$ Radio-Canada television service through their taxes and did not see why they should incur 
additional costs to receive its television programming. Concerns were expressed by 15 households regarding Internet data cap overage fees that would be incurred if they leveraged such platforms to access CBC/Radio-Canada television programming. Twenty-one of the 99 households interviewed for this dissertation advised that they had signed up to Shaw Direct's LTSS program and as such were able to access CBC/Radio-Canada television programming by way of satellite for no additional cost. These LTSS household were wary of the eventual end of the program which would require them to start paying for satellite.

Almost all (93 of the 99) previously analogue OTA CBC/Radio-Canada televisionviewing households interviewed for this dissertation were not served by CBC/Radio-Canada's digital OTA television transmitters. Cable television service was reported as unavailable by 30 households. Fourteen households noted a lack of CBC/Radio-Canada television programming online and 13 households reported concerns related to $\mathrm{CBC} /$ Radio-Canada programming being available via live stream.

Eleven disconnected CBC/Radio-Canada OTA television viewing households advised that they no longer had à la carte style access to the public television broadcaster's television programming, apart from uneven viewing of programming online. Of the disconnected homes, Shaw LTSS households came the closest to achieving à la carte service.

The ability of disconnected CBC/Radio-Canada OTA television viewing households to gain access to locally relevant feeds by way of BDU service was mixed. Five households gained access to a $\mathrm{CBC} /$ Radio-Canada station via $\mathrm{BDU}$ but not to the same $\mathrm{CBC} /$ Radio-Canada station(s) that they had watched OTA that had been more locally relevant to the household. Three households in Newfoundland and Labrador noted that they were unable to receive CBC 
Television's St. John's station via Shaw's LTSS (other than the St. John's supper-time news show, if and when Shaw opted to feature it on Shaw Direct's home channel). 


\section{B) CBC/Radio-Canada Management interviews}

Drawing from research interviews conducted with five members of CBC/Radio-Canada Management involved in the public broadcaster's response to Canada's digital television transition deadline, insight into CBC/Radio-Canada's reasoning behind the end of its analogue OTA television service and the implementation of its truncated digital OTA television service follows.

\section{Access to CBC/Radio-Canada television via analogue OTA broadcasting}

\section{1) Cost}

The analogue infrastructure's not really giving us a lot of audience. It's costing us $\$ 14$ million a year to operate not including the satellite stuff. We're not serving Canadians with that. We can take that money and put it into programming. Use it better than we're using it there. (MGMT003)

All members of $\mathrm{CBC} /$ Radio-Canada Management interviewed for this dissertation indicated that the annual costs (publicly stated to be $\$ 10$ million but quoted by MGMT003 above as $\$ 14$ million) associated with the continued operation of CBC/Radio-Canada's analogue OTA television service outside of mandatory digital markets and outside of the $700 \mathrm{MHz}$ band were out of proportion to the number of Canadians that benefited from the analogue OTA service. As noted by MGMT004:

We estimate that only $1.7 \%$ of the Canadian population is using analogue over-the-air analogue transmission right now. $1.7 \%$. So that's a few hundred thousand people...It's very difficult for us to justify taking money out of programming and from new platforms that Canadians are going to, increasingly going to, and using it on a technology where only $1.7 \%$ of Canadians are using it. So it was a pretty easy decision for us. We simply couldn't keep going in analogue, we couldn't keep going in analogue..even in the main markets outside the mandatory markets....Keeping the analogue infrastructure alive is over $\$ 10$ million a year. We simply can't justify. 
CBC/Radio-Canada Management's primary focus on what different modes of television delivery (particularly analogue OTA delivery) were costing CBC/Radio-Canada, rather than a primary focus on what television delivery was costing, or would cost, Canadian televisionviewing households reflected the dominant discourse guiding the public broadcaster's operational response to Canada's digital television transition deadline.

In terms of the insight $\mathrm{CBC} /$ Radio-Canada Management shared into the costs for previously analogue OTA television-viewing households to continue to access $\mathrm{CBC} /$ RadioCanada television programming, MGMT003 noted that access to CBC/Radio-Canada television programming would end for households situated beyond the reach of its digital OTA television transmitters that did not start paying additional fees to access the public broadcaster,

For those people who only watch $\mathrm{CBC}$ over-the-air and don't want to pay for cable and don't want to pay for satellite, they're going to be left behind. I hate to say that but that's the end of the day. That's the end of the game for them. (MGMT003)

Furthermore, MGMT004 stressed that "there is no requirement in the Broadcasting Act that TV be free. There is a requirement however that cable service and satellite service be affordable". While MGMT004's statement about there being no regulatory requirement for TV to be free it was likely made in reference to costs incurred by Canadian television-viewing households to access their $\mathrm{CBC} /$ Radio-Canada television programming, such a statement equally applies to costs incurred by a television broadcaster to deliver its programming. There is similarly no requirement in the Broadcasting Act that television be free for CBC/Radio-Canada to deliver either.

$\mathrm{CBC} /$ Radio-Canada Management's main interest in the costs associated with its analogue OTA television service were costs incurred by the broadcaster. Management was of the opinion that the cost to continue to operate its analogue television transmitters in non-mandatory 
television markets did not serve enough households to make it worth continuing, even though such expenditure only represented roughly $0.5 \%$ of its annual operating expenses.

\section{2) Availability}

[W]ith analogue, you're getting something probably well past your theoretical contour, what the engineers would tell you is your Grade B contour. The engineers would say, past Grade B, I don't guarantee what you're going to get. Well in the real world, in Saskatchewan, you've probably got a usable signal most of the time, depending on what the weather was and depending where your house was and how high the mast of your antenna was. (MGMT001)

As described above, a benefit of the public broadcaster's analogue OTA television service was the phenomenon of television signal availability provided by analogue OTA television signal drift. The possibility of Grade B contour reception meant that analogue OTA $\mathrm{CBC} /$ Radio-Canada television-viewing households that were not guaranteed to be able to receive OTA television services from the public broadcaster, did.

Despite this fringe benefit, all members of $\mathrm{CBC} /$ Radio-Canada Management who were interviewed for this dissertation nonetheless stressed that the number of OTA television-viewing households in Canada that relied on its analogue OTA television transmitters for access to the public broadcaster in the twenty-first century was low. As expressed by MGMT001, viewer reliance on CBC/Radio-Canada's analogue OTA television transmitters was seemingly nonexistent,

When we started looking at how people were using our (analogue) over-the-air television network we discovered that we have many of those 600 some-odd transmitters in very small communities. Our transmitter techs would go in those communities and what they would discover is that the transmitter had been off the air for a month because lightning had struck it. That actually happened in a little town called Eastend, Saskatchewan. (MGMT001) 
Implied in this answer was that analogue OTA television broadcasting was not key in

making CBC/Radio-Canada television programming available to Canadian households. As noted by MGMT005,

In looking at how Canadians consume or receive television services, we've moved from a world where people are taking their television services from over-the-air to a world where the vast, vast majority are obtaining television services from BDUs. There are some people actually who are even getting or receiving content on the Internet. You only have a small number of people that are receiving content via over-the-air. When you look at it and you think, what's the best and most efficient way under the Broadcasting Act, as the Broadcasting Act says to deliver our services, it makes better sense to focus on our content rather than focus on the distribution. BDUs do a great job of distributing our services and offering actually a range of services to Canadians and they've embraced them. (MGMT005)

Four of five of the members of CBC/Radio-Canada Management interviewed stressed that the focus of the public broadcaster's television services was on the creation of Canadian television programming and not the direct delivery of such television programming to Canadian television-viewing households by way of publicly owned and controlled infrastructure. Instead, BDU, ISP, and mobile wireless service providers were cited by the following members of $\mathrm{CBC} /$ Radio-Canada Management as the best ways to make its programming available to viewers, not OTA signals:

As time goes on, people have said in the last few years, are people going to cut the cord? Even with the availability of the Internet, people continue to receive their services via BDU and they're now turning to the Internet but there hasn't been the upswing of people turning to over-the-air. That's kind of an old technology that doesn't have the same...there are other better alternatives in Canada which Canadians have determined that that's the way they want to receive their services. (MGMT005)

The issue is how do we get our signal the most efficiently from our production centres to the viewer and ensuring that if people are using BDUs we make sure the BDUs have our signal? If the consumer is moving towards mobile TV, well let's make sure we're in the mobile TV space. If the consumer's moving to IP type solutions, well let's make sure our signals are available through IP because our goal is to get the signal, as a public broadcaster, is to get the signal to the consumer. It's not so much what technology we're using. It's...we want to use the technology the consumer is using. That's what we have to do. It's not that we have to be over-the-air or on this platform or that platform. We want to 
be on the platforms that consumers are using. The public. The Canadian public. (MGMT002)

However, an indication of at least some value being associated with CBC/RadioCanada's analogue OTA television network was expressed by the following member of CBC/Radio-Canada Management regarding CBC/Radio-Canada having received a one-year extension from the CRTC that allowed it to keep 22 of its analogue transmitters operational until August 31, 2012,

The idea was, as long as we could continue to do this, and we had the transmitters there and we had the resources that were able to, if we had to fix the transmitter or there was electricity, we were able to do it. So we were happy that the Commission allowed us to do this because it was a bit of a cushion between the real cut-off date and there was this sort of grace period and some people were able to continue to receive over the air service. I don't think there were that many Canadians that are receiving their service over-the-air, but we were very happy that the Commission was allowing us to do this. They had the discretion to say no and they didn't. So we were pleased. (MGMT005)

According to MGMT003, CBC/Radio-Canada was ideally hoping to have kept its analogue OTA television transmitters operational beyond even 2012, noting "I think (the) manpower challenge was really the big one because our original planning was 2013 to shut everything down. To do the digital transition, that was moved up". The fact that CBC/RadioCanada Management wanted to keep its analogue OTA television transmitters operational until at least 2013 implied that there would have been some measure of positive benefit to their continued operation despite the final figure of $\$ 10$ million in additional expenses that the extra year of analogue OTA television broadcasting would have reportedly cost the public broadcaster.

Part of CBC/Radio-Canada's television delivery challenge, as noted by three of the five members of CBC/Radio-Canada Management interviewed, was that vertically-integrated Canadian BDUs are not simply benign platform partners that $\mathrm{CBC} /$ Radio-Canada relies on to faithfully deliver its public television programming across the country. As described by 
MGMT003, "[t]here are two or three Goliaths standing around us. We're sitting here without anybody supporting us as a public broadcaster. It can be daunting and very lonely at the same time". That being the case, MGMT003 noted that one of CBC/Radio-Canada's responses to this television delivery battle of Biblical proportions was to invest in its own fibre optic content delivery system so that the public broadcaster could distribute information largely in-house without having to rely on $\mathrm{CBC} /$ Radio-Canada's frenemies:

(W)e built our own fibre network last year. We used to lease from Bell. We had a relationship for almost 50 years with them. We decided to build our own high-speed fibre optic network across the country. You see the screens out here (points out of the room). Outside, these are the guys who are operating it. We're taking that in-house because it's so strategic. It's helped us to fortress CBC. To control our own destiny. We have our own network. All of our production centres are now networked together. Somebody can drop content in Vancouver and drag it across a network to a desktop in St. John's, Newfoundland. It's amazing what this network can do. We've become a media company now. We've been able to do that without the vertical integration but I'm telling you, it's a challenge. So, I think the key thing is power in the market place these guys [vertically integrated Canadian media companies] have. The resources they can have. They can make decisions on investments and they don't really have to justify the bottom line. They can make strategic investments in order to meet a political need. Very interesting. And we've seen that on and on and on. Bell Canada and CTV.

\section{3) Functionality}

Apart from a joke made by MGMT003 about the American NTSC analogue OTA television standard used by Canada as standing for "Never the Same Colour Twice", the role of analogue OTA television transmitters was not specifically mentioned by $\mathrm{CBC} /$ Radio-Canada Management with respect to the functionality (meaning, the audio-visual quality of the access) of $\mathrm{CBC} /$ RadioCanada's delivery of television signals to Canadian analogue OTA television-viewing households. As expressed by MGMT005, "there hasn't been the upswing of people turning to over-the-air. That's kind of an old technology". 


\section{4) A la carte}

The (CBC/Radio-Canada) analogues are going to be switched off and that will be the end of analogue television from the CBC. The privates will continue operating their analogues but my prediction is not for long. They'll watch and see what kind of a shitstorm happens and if it's not a big shitstorm their's will go too. (MGMT001)

CBC/Radio-Canada Management did not explicitly discuss à la carte television access in relation to its analogue OTA television transmitters.

\section{5) Locally relevant feed(s)}

Most of our analogue transmitters are outside the station areas. So really they are rebroadcasting. We start with 650 transmitters, 630, or 620 some odd, were just rebroadcasting the signal from a station. They weren't actually broadcasting original programming. That was only coming from the transmitters from the 27 stations. So if you look at it that way, what's the impact of getting rid of our analogue transmitters, putting in digital where we have stations, what are the impacts for the stations? Well, really there's no impact because there's no reduction in programming. The programming that we were creating before is still being made in all of our stations because that's the only place it was being made. (MGMT004)

CBC Radio-Canada Management's discussion of the role that its analogue OTA television transmitters might have played in the delivery of locally relevant feeds to Canadian television-viewing households was limited to the above-quoted statement by MGMT004, which noted that CBC/Radio-Canada's analogue OTA retransmitters hadn't been broadcasting original locally relevant programming to communities that stood to lose OTA television access to the public broadcaster anyway. While this is certainly a good point, a shift from regional OTA CBC/Radio-Canada television access to no OTA CBC/Radio-Canada television access does not represent "no impact" to viewers and certainly wasn't an improvement in terms of access to CBC/Radio-Canada television programming. In fact, the following quote from MGMT003 notes 
that efforts were indeed made to accommodate Canadians in terms of access to CBC/RadioCanada television post-analogue OTA, although such access still requires use of a BDU:

Since we're shutting down our analogue transmitters, and we're only building 27 DTV, there's a big gap there, so we wanted to make the signals readily available to cable. So, we put them all up on satellite and we've told cable, 'it's there, come and get them'. It's all together. Halifax and Vancouver is all on the same satellite. So whatever feed you want, there's 24 of them up there. So we've designed the system to make it easily received by cable. (MGMT003)

If 24 of CBC/Radio-Canada's television feeds are now conveniently all located on the same satellite, and easily received by BDUs, it raises the question of why this system can't also be configured such that locally relevant feeds could also be easily received by $\mathrm{CBC} /$ RadioCanada television viewing households directly. In terms of the delivery of locally relevant CBC/Radio-Canada television feeds to households located in Canada's North, according to MGMT003, the end of analogue OTA CBC/Radio-Canada television delivery was a particularly "sensitive" matter:

In the analogue world we had two releases to the North. We had a Yellowknife release and a Whitehorse release. Separate super-hour shows. In the digital world, there is one for the North. There's a real decision there as to who you feed. The North is always sensitive... because it's the North. That was a sensitive one. (MGMT003) 


\section{Access to CBC/Radio-Canada television post-analogue OTA broadcasting}

\section{1) Cost}

The one thing we've been very vocal about at the CRTC is we've been promoting for quite some time that there should be a very low cost, if not free basic package for Canadian content on BDU systems. We've been promoting that. You hear it sometimes called Skinny Basic. (MGMT003)

The dominant theme communicated by all interviewed members of CBC/Radio-Canada

Management on the reasoning for the public broadcaster's decision to abandon analogue OTA television broadcasting entirely, and to only install 27 digital OTA television transmitters, was that it wasn't worth the money to replicate its analogue OTA television service's infrastructure with digital OTA television infrastructure,

[We asked ourselves], if we took all the analog transmitters and converted them to digital, we just replicated the coverage $99.9 \%$ of Canadians in their homes, how much that would cost and it was $\$ 1.3$ billion to do it. Because of the fact that ACP [Accelerated Coverage Program] had put a transmitter in communities of 500 or more. There are hundreds of those. If you want to replace those with DTV you're talking a massive investment. Obviously that wasn't going to work so we looked at different models. (MGMT003)

[Spectrum] is the resource we're using. It's extremely valuable and I think the government's finally woken up to its value. We're being forced down the totem pole, lower and lower and lower. I can see the day when we're not going to have much access. We don't own anything. We're just licensed to use it and we make money off it but the government doesn't get a piece of that action. They will with this other player. In terms of non-human players, that's one of the biggies for sure. (MGMT003)

As time wore on through the decade of 2000 and up until today, what we've been doing is balancing the realization that the decline in over-the-air usage has continued to the point today where depending on which numbers you use, it's as little as 5\% of Canadians are using over-the-air, maybe even less. So the realization is, OK, so we're not going to duplicate with such a small usage, we can't afford it and it doesn't make sense, from an appropriate, efficient technology point of view, so we've arrived at the situation that we have now in 2012 where we've put digital television transmitters only where we have television stations to meet the regulatory obligation and we're not going beyond that. (MGMT003)

While four of the five members of CBC/Radio-Canada Management interviewed stressed the value of making a move from standard definition (SD) television programming to high 
definition (HD) television programming, the same number also stressed the cost of switching to $\mathrm{HD}$ as a factor in $\mathrm{CBC} /$ Radio-Canada's final approach to the transition. As noted by MGMT002, the transition to HD was a "glass to glass" endeavour for the public broadcastet. In other words, ranging from the glass of the viewfinder of an HD video camera that records television footage, to the glass of the screen that a viewer uses to watch a completed $\mathrm{CBC} /$ Radio-Canada television program, everything between those two screens needed to be changed from SD to HD. As accounted for by MGMT002,

For the 27 [digital OTA transmitters] we did, it was $\$ 20$ million. That price varied between about $\$ 500,000$ up to about $\$ 1.5, \$ 1.6$ million...Remember, this is just the transmitters not the distribution and does not include the production and the presentation and all that. The conversion for $\mathrm{CBC}$ for the presentation, the distribution, and the transmitters was $\$ 64$ million. Still not included in that number is the conversion of the production facilities from SD to HD, not including cameras in the studios in that number.

As explained by MGMT004,

The opportunity for us has been to realize that, hey, we've got to make some choices and now we can see that we have the opportunity to take some of that investment that we made in a declining technology and the costs associated with that investment and we can transfer them over to other platforms where Canadians are going increasingly. In some of the small markets in Canada, more Canadians are accessing our services online than they are using over the air technology. We've been given this opportunity to realize over-the-air is but one platform and it's a platform that's not really a popular one that's growing, it's a platform that's declining so it's given us a chance to shall we say rationalize our thinking about how to spend money within the company. (MGMT004)

As further noted by MGMT004, "It's really hard to justify going digital in those areas...A digital transmitter can run up to a million or more dollars". For MGMT003, $\mathrm{CBC} /$ Radio-Canada's digital OTA television network was an asset that assisted the public broadcaster when facing Canada's BDU “Goliaths",

We design, build and operate the 27 digital, 26 now but will be 27 digital transmitters that are on the air right now... We've also built across the country a new fibre optic network which is actually the third or fourth biggest media network across the country. It's called 
the Next Generation Converged Network, or NGCN, and that carries all the signals on the ground. On the two uplinks, we have a major one in Toronto on the roof and one in Montreal at the Maison. We carry, I think it's 14 signals out of here and 10 out of Montreal and there's three on the ground. So there's 27 digital releases and we carry 24 on satellite, split between Toronto and Montreal... (MGMT003)

Since roughly two thirds of CBC/Radio-Canada annual revenue for its operations comes from its federal allocations, the public broadcaster relies on other sources of revenue to cover the remaining third. One of the main sources of other revenue for the public broadcaster since the mid-1950s has been revenue from selling commercial spots to advertisers. While the operation of an OTA television transmitter, analogue or digital, in any given television market would reasonably be thought to be predicated on the delivery of television to television viewers, discussions with three of the five members of CBC/Radio-Canada Management interviewed for this dissertation revealed a different industry-wide motivation for continuing the operation of television transmitters in the digital age. The motivation was that local OTA television transmitter operation is tied to how OTA television transmitter signal footprints have historically determined Canadian advertising rates in television markets. As explained by MGMT001,

The entire Canadian television system is based on over-the-air footprints. Your right to sell commercials or not to sell commercials in a market on an over-the-air signal depends on your footprint and whether or not you're producing content that's tailored to that footprint. Advertising measurement is all based on your over-the-air footprint. Simulcast rights are based on over-the-air footprint. There's a whole bunch of things that are built into the legacy broadcast structure, and they're interlocking things, that if you were going to do away with the over-the-air system you would have to unpick all of that. I think the CRTC looked at it and said, it's been working for us for 50 years, we really don't want to do that. Everything's been built on it. Cable's been built on it. Satellite's been built on it. So it basically would be blowing up the system and starting again. They chose at that time not to do it. They could choose to do it at some other time but they choose not to do it at that point. So we as broadcasters knew when those policies came out, OK, there's going to be digital TV over-the-air, and it's going to be focused on HD and we'll start working to see what that looks like. (MGMT001)

As noted in earlier chapters, under the leadership of past Head of English Services Richard Stursberg, there was little appetite for the public broadcaster to build out additional 
digital OTA television transmitters as a means by which to deliver $\mathrm{CBC} /$ Radio-Canada television programming to Canadians. Based on the interviews conducted with members of $\mathrm{CBC} /$ RadioCanada Management, the main reason why $\mathrm{CBC} /$ Radio-Canada has any digital OTA television transmitters, at all, beyond its first five digital OTA television transmitters according to MGMT001, was due to the fact that the private television broadcasters in Canada, such as CTV and Global, started building out their digital OTA television transmitters. In order to compete with the private television networks for advertising dollars, $\mathrm{CBC} /$ Radio-Canada expanded its number of digital OTA television transmitters outside of Toronto, Ottawa, Montreal, Quebec City and Vancouver. Since OTA was proclaimed by the CRTC as the main mode of HD television delivery in Canada, and since private OTA television broadcasters were building out their own digital OTA transmitters in additional markets, $\mathrm{CBC}$ /Radio-Canada followed suit. As such, the public broadcaster's expanded digital OTA television transmitter build out (meaning, beyond five) was not based on providing additional OTA digital television service to citizens. According to MGMT001, the digital OTA television transmitters that were built were mainly there to compete with private OTA television broadcasters for advertising dollars, and according to MGMT004, "[w]e've got both the requirement from the CRTC that if we broadcast, it's got to be in digital, and there's a regulatory requirement that if you have a station you to have to have a presence...We have to have a presence in a market if you have a station".

In terms of household costs associated with the reception of $\mathrm{CBC} /$ Radio-Canada television programming, four of the five members of $\mathrm{CBC} /$ Radio-Canada Management interviewed advised that such costs would best be mitigated through the introduction of a Skinny Basic BDU regulation that would provide affordable access to $\mathrm{CBC} /$ Radio-Canada television (although CBC/Radio-Canada itself would not be providing such a service to households). Two 
members of CBC/Radio-Canada Management interviewed named Shaw Direct's LTSS as an existing service that could provide no-fee access to $\mathrm{CBC} /$ Radio-Canada programming.

Two of the members of $\mathrm{CBC} /$ Radio-Canada Management interviewed for this dissertation cited government regulation of $\mathrm{CBC} /$ Radio-Canada as influencing the public broadcaster's final approach to its digital television transition more than a lack of funding to cover the cost of the digital switch.

\section{2) Availability}

Digital's good 'til it isn't. So, with analogue, you're getting something probably well past your theoretical contour, what the engineers would tell you your Grade B contour. The engineers would say past Grade B, I don't guarantee what you're going to get...In the digital world, that all changes. (MGMT001)

In terms of the availability of $\mathrm{CBC} /$ Radio-Canada television programming following

the shutdown of its analogue OTA television service, members of CBC/Radio-Canada

Management interviewed reported differing figures in terms of the cross-country OTA availability of its television programming post-analogue. For MGMT001, $80 \%$ of the mother tongue population, English and French, would receive OTA television service care of CBC/Radio-Canada's 27 digital OTA television transmitters. However, according to MGMT002 and MGMT003, CBC/Radio-Canada ability to reach $80 \%$ of the mother tongue population, English and French, would require the use of 44 digital OTA television transmitters. As noted by MGMT001 below;

We said, how many transmitters does it take to reach what percentage of the population? Very classic yield curve. Where the yield curve intersects with the population is at $80 \%$. That's where our 27 transmitters across the country came from. That's the number, in round numbers, that we actually reach $80 \%$ of the Canadian population at a reasonable price... It probably took two years to work all the way through that. In 2008 we kind of knew that that's what we would be doing. That we wouldn't be building out. We knew in 2006 we weren't building out 650 transmitters. There was just no world that was real. (MGMT001) 
Three of the five members interviewed noted that the final number of 27 digital OTA television transmitters was ultimately based on the fact that it was the minimum number of television transmitters that the public broadcaster had to continue operating in order to meet its regulatory obligations. All members of CBC/Radio-Canada Management interviewed argued that Canadian households outside of the 20 markets with CBC/Radio-Canada digital OTA television transmitters would continue to receive access to $\mathrm{CBC} /$ Radio-Canada's television programming by other means.

In terms of CBC/Radio-Canada Management's operational reaction to Canada's digital television transition, one hard deadline that the public broadcaster (along with all other licensed OTA television broadcasters in Canada) had to meet by August 31, 2011 was to make changes to its stations broadcasting on the UHF channels 52 to 69 . As noted earlier, this was the prime spectrum known as "beachfront property" (Taylor, 2013, p.33) that the government of Canada wanted to auction to wireless service providers and a core reason for Canada's digital television transition. According to MGMT002,

We had to vacate the channel 52 to 69 spectrum by August 31, 2011. It wasn't a huge problem it was just one more thing we had to manage. We had 18 stations that operated in that part of the frequency band. So for each of the 18 we had to come up with a solution and the solutions varied. In some cases, we did change channels from in the 50s to something below channel 52 . In some cases we used a regulatory provision. What we did, rather than licensing those stations as protected, we reduced power and converted our licence to unprotected stations so that we didn't actually change the channel but we took the risk that we would not be interfered with.

As collectively told by the members of CBC/Radio-Canada Management interviewed for this dissertation, at least four main potential approaches to CBC/Radio-Canada's digital television transmitter build out were explored over the years. These approaches included, i) 
digitally replicating $\mathrm{CBC}$ /Radio-Canada's existing analogue OTA television network of more than 600 analogue OTA television transmitters/retransmitters, ii) adhering to the CRTC's 2007 mandatory digital television market decision that would see digital transition in provincial capitals, the nation's capital, and markets of 300,000 or more residents, iii) installing a total of 44 digital OTA television transmitters and finally, iv) installing a total of 27 digital OTA television transmitters in 20 markets.

In terms of "the full meal deal" (MGMT002), also referred to as "the Full Monty" (MGMT001), that involved replicating CBC/Radio-Canada's entire analogue OTA television service comprised of more than 600 television transmitters/retransmitters with digital OTA television transmitters/retransmitters, including "400 ACP stations in the North" (MGMT003), was pondered by $\mathrm{CBC} /$ Radio-Canada Management, but ultimately considered to be unrealistic;

Ideally, we would have done a complete conversion however that would have been extremely costly and it wouldn't have been possible for the company to finance that, hence the obvious request to the Federal government for financial assistance to do a full conversion. Once it became clear that we weren't going to get financial assistance obviously we had to scale our plans back significantly. (MGMT002)

While adhering to the CRTC's mandatory digital television market list would actually have involved $\mathrm{CBC} /$ Radio-Canada installing less transmitters than replicating $\mathrm{CBC} /$ RadioCanada's entire analogue OTA television service, the following example provided by MGMT002 outlines how CBC/Radio-Canada Management found the CRTC's mandatory digital market list problematic in terms of both cost and the markets served,

One other thing we had to look at... was the mandatory markets as issued by the CRTC but even that wasn't affordable for us. It did move around a bit and had a few illogical inconsistencies. Some of the mandatory markets from the CBC perspective didn't make sense. I'll give a simple example. Chicoutimi was a mandatory market. The expectation from the Commission was that we would convert our French transmitter, logical mandatory market, but we also have an English transmitter in Chicoutimi which the CRTC expected us to convert. That makes no sense for CBC. You understand why that doesn't make sense for us. Why would we do an English DTV transmitter in Chicoutimi with a very, very 
small Anglophone population when we're not doing communities that are hundreds of times bigger and are not mandatory? It didn't make sense. Some of the ones on the mandatory markets did not make sense for us. Thunder Bay, it would have been mandatory for us to do French in Thunder Bay, but not Rimouski. There were a few little odd-ballers in there for CBC and Radio-Canada that didn't make sense to us. (MGMT002)

As for the 44 digital OTA television transmitter plan, the rationale was that 44 transmitters would provide service to a reasonable percentage of viewers. According to MGMT002, the understanding was that the 44 digital OTA television transmitters would serve “ $80 \%$ English mother tongue and 80\% French mother tongue... of which 28 would of been English and 16 would have been French". However, 44 transmitters was ultimately considered hard to justify "politically and intellectually" according to MGMT003:

The reason 44 was difficult to defend because in those 44 you had stations that weren't originating stations, right? Let's say one of those stations is Sherbrooke, QC. We have Montreal DTV. It originates programming, it's licensed, no problem. Sherbrooke is a rebroadcaster. So we say yes to Sherbrooke, but we're saying no to Sydney, we're saying no to Cornerbrook, we're saying no to Lethbridge. How can you do that? You can't defend that position, politically or logically. That's why the 27 came down. Because it was the only, I think, the only politically and intellectually defensible position going forward....0 to 1.3 billion. And then we looked at percentage of population. You exclude the North. Well, why are we excluding the North if we're doing the South? Every model we looked at had a problem. We weren't in this luxurious situation of replicating a new car from an old car. We couldn't replace the old car. It had to be something completely different. You get down to what is politically and intellectually justifiable. When you get down to saying, well, I'm going to build a station in Sherbrooke because I think they'd really appreciate it. I think they would. But you can't say yes to them and no to someone else. (MGMT003)

While the public reason given by $\mathrm{CBC} /$ Radio-Canada into why a total of 27 digital OTA television transmitters was ultimately chosen was based on a plan of having at least one transmitter in each market where it created original television programming, a number of more detailed explanations for the 27 digital OTA television transmitter figure were given by the following members of CBC/Radio-Canada Management interviewed: 
I think we came out with 44 at some point in the 2000s. Even that seemed to be too many because we saw that the over-the-air usage was continuing to decline. We ended up at 27 as a kind of minimum number that we had to do to in order to meet the regulatory obligations for our stations as we have 27 stations. We've done the minimum because we've had to and that's been a reflection of I think the fact that it's hard to justify spending a lot of money when there's so few people using the technology. (MGMT005)

It really came with discussions with our clients that it came down to, where we have a licence to originate original supper hour shows, that's originating stations. That's what made sense. So, there wasn't a corporate decision to overbuild. It was just Engineers saying, what's the limit of the equation here? We knew someone was going to ask that one day. Someone from the press. Literally. Why didn't you overbuild everything? We'd say, it's billions of dollars. The Executives said, they knew the Internet is there, is coming, growing and other forms of delivery so it really was, well what does 75 transmitters look like? What does $75 \%$ of the population look like? It was never $100 \%$. We had the answer because we knew we were going to be asked, but nobody took that seriously because you wouldn't build a digital transmitter in Bella Coola, Bella Bella, and these places in Northern Ontario and Quebec because they have cable and they have direct to home. They have options. Frankly, the television model, the conventional over-the-air television model financially is broken. We're not getting paid for what we should be getting paid. It doesn't make sense financially, as my boss always says. So, that's why we cut it off at 27. (MGMT003)

There hasn't been the upswing of people turning to over the air. That's kind of an old technology that doesn't have the same...there are other better alternatives in Canada which Canadians have determined that that's the way they want to receive their services. If you're a Francophone, for example, outside of Quebec, if you want to receive more than just Radio-Canada's over-the-air service, if you want to get some other television services, for example TVA which is distributed on cable on basic across Canada, if you want to receive other French language services, you gotta have a BDU subscription. You've got to be a cable or DTH customer. In recognizing that, that also led us to adopt an approach that would, we decided in those markets, where we originate programming, where we have a television station where we originate programming, we will have an over-the-air transmitter. In other markets where we don't originate, where we are re-broadcasting, we will not implement a digital television transmitter. (MGMT005)

Lastly, MGMT001 noted that in contrast to Canada, the U.S. digital television transition

"made sense" for Americans due to the lack of cable and satellite penetration in their country:

Over-the-air use (by U.S. viewers) lacking cable and satellite was over 30\%. In Canada at the time I think it was 10 . And there were parts in the States where it was closer to $50 \%$. So, the Americans weren't nearly as penetrated by cable and satellite at the beginning of the process as Canada was. And that made a difference in how people were viewing DTV roll out here from there. (MGMT001) 
MGMT003 also noted the following difference between the U.S. and Canadian digital

television transitions:

In the States, there are many industry committees saying we should do this and broadcasters have to get on board and build their transmitters and invest and make the transition even though there isn't a major payback. It's just where the industry is going. In Canada, it was like, pass the ball in the federal government. Nobody wanted to touch this file. It was like, it's political suicide to make a decision on DTV because no matter what you do you're going to piss somebody off... We couldn't get any direction from Heritage. We couldn't get any direction from Industry Canada... It was only the Commission that did something and even that wasn't ground-breaking but at least they did something.

(MGMT003)

In terms of Canadian households turning instead to OTA television signals from U.S. television transmitters in response to a lack of availability of OTA CBC/Radio-Canada television signals, a member of $\mathrm{CBC} /$ Radio-Canada Management noted that "whatever happens in the States with over-the-air, by necessity, has an impact on Canada, at least along the border because of the fact that Hertzian signals don't know borders. They just travel” (MGMT001).

Furthermore, the following members of CBC/Radio-Canada Management noted that the reach of OTA television signals digitally was also tied to the relationship between a digital OTA television transmitter and the landscape surrounding it,

In downtown Toronto we're on the $\mathrm{CN}$ Tower. We're getting massive, great penetration into the condo areas and even into the homes in the suburbs. (MGMT003)

Terrain plays a very direct role in terms of coverage. It's not so much about DTV it's about where you are in the spectrum. That's all about hills being in the way, mountains being in the way. People being in valleys. We covered a large part of Central Saskatchewan with two, three, four analogue transmitters. We've replaced those with one digital transmitter which doesn't cover nearly as far. The reason I mention that is because Saskatchewan is flat, essentially. So terrain is not an issue there. The issue is what the digital boys like to call a digital cliff. (MGMT001) 
MGMT005 expressed faith that BDUs would continue to deliver CBC/Radio-Canada

television programming in the post-analogue era,

We expect that BDUs will continue to provide CBC signals. There may be some cable companies that previously got the signal over-the-air and then they would then put it as part of their basic package and Canadians would pay for it. There may be some pockets in Canada where the cable company as of July 31 st will no longer be able to receive that signal over the air. Those cable companies though probably receive some other signals from SRDUs (Satellite Relay Distribution Undertaking). There are two. Shaw operates one and Bell operates one. I think Shaw's is a bigger business. Most cable companies get their signals from Shaw's SRDU service. If you're a cable company, you may receive your specialty channels via Shaw, you may receive some over the air signals that aren't over the air for you...If you're a cable company and you're no longer able to pick up CBC or Radio-Canada's signal over the air because you don't have a retransmitter in that market. For a very very small cost you can continue to receive CBC/Radio-Canada's signal but you just now need somebody to get it to you and that's where Shaw comes in. Shaw provides that service already.

The only member of the CBC/Radio-Canada Management members interviewed for this dissertation to respond to follow-up questions following the public broadcaster's analogue OTA television transmitter shutdown, MGMT003, reported "no unexpected negative outcome that I can cite" (MGMT003). Instead, MGMT003 felt that the transition had been a success:

CBC/Radio-Canada's transition from analogue to digital was a success as a technological project. On July 31 st, we were able to shut down over 600 analogue TV transmitters by remote control across the country at the "stroke of midnight". We also shut down the satellite distribution system feeding these transmitters in Montreal and Toronto and shut down an older French Television satellite distribution system that was installed in the early 1990s, that was used to feed snowbirds in Florida. (MGMT003)

The transition was likely understood to be a success for MGMT003 because CBC/RadioCanada had shut down its analogue OTA television transmitters along with other analogue television distribution systems associated with the analogue OTA transmitters. The aim for CBC/Radio-Canada Management, as per the public broadcaster's final transition plan, was to shut down its analogue OTA television service and that's what CBC/Radio-Canada had achieved. CBC/Radio-Canada's OTA television reach across Canada was drastically reduced as 
a result, decreasing the availably of its OTA television signals to households outside of markets with digital OTA television transmitters, and yet it was still considered a success by MGMT003. In addition, the fact that there was no "mass protest" following the shutdown of $\mathrm{CBC} /$ RadioCanada's analogue OTA television transmitter shutdown was also considered by MGMT003 to equal success. The reasoning behind this perspective is likely that only a mass number of complaints about the loss of OTA television delivery availability would have served to challenge CBC/Radio-Canada's final approach to Canada's digital television transition. As noted by MGMT003,

One of the positive outcomes was that, due to a communications campaign with both BDUs, SRDUs (Satellite Relay Distribution Undertakings), and the general public, the reaction to the shutdown was not a mass protest. The amount of calls and e-mails we received was similar to that expected after a large broadcast event, etc. Our Communications department characterized the public reaction as large but not unusually so, and most questions were directed at how to receive our DTV services. - MGMT003

In terms of the future of $\mathrm{CBC} /$ Radio-Canada's remaining 27 digital OTA television transmitters, while MGMT003 noted that the Corporation would continue to operate its digital OTA television transmitters for at least five years, there was no mention made by $\mathrm{CBC} /$ RadioCanada Management of enhancing its digital OTA television network or of adding any additional digital OTA television transmitters elsewhere in the country,

CBC/Radio-Canada will continue to operate our 27 DTV transmitters for the foreseeable future and that would include the next five years. We don't foresee any growth in the number of transmitters, as that would entail producing a customized feed for the transmitter in question from the broadcast centre. Our growth will be in stations like Hamilton that produce TV and Radio content, but only post it on the web. There is no OTA DTV transmitter associated with this station. (MGMT003)

\section{3) Functionality}

The conversion to digital obviously provides a higher quality product for the viewer. The transition in our mind has always been a transition to HD digital. Not SD. (MGMT002) 
CBC/Radio-Canada Management's main motivation for shifting to digital television operations, according to MGMT001, was the promise of high-definition television (HDTV):

The original story really started with HD. It didn't start with over-the-air. We had lots of meetings. We weren't talking about how it gets delivered at that point. Delivery became part of the conversation at some point early on but it didn't become a focus for quite a while. (MGMT001)

This note concurs with Gregory Taylor (2013) who argues that digital television in Canada "evolved from HD, not the other way around as is commonly thought" (p. 54). As the name suggests, HDTV involves high-definition picture and sound quality that is noticeably improved over the standard definition (SD) television standard used in Canada since colour television was introduced in Canada in September 1966 (CBC/Radio-Canada, 2017). Not all digital television is HD. Many digital OTA television signals distributed by U.S. television stations for example are standard definition (SD). However, digital television technology allows for the possibility of HD delivery. Indeed, CBC/Radio-Canada's first foray into offering HD television content (an NHL hockey game) happened more than a year before it had any digital OTA transmitters operational and as such was distributed in HD solely by BDUs. As recollected by MGMT001,

2003 was essentially the dawning of HD in Canada. We did the Heritage (Classic) out of Edmonton in 2003. It was the first live sports broadcast in Canada in HD, I believe. Certainly the first NHL hockey game in HD out of Canada. That was done really to understand what the viewer proposition was and also to understand what the production costs were.

Growth in the Canadian sales of HD television sets was also mentioned by MGMT001 as factoring into CBC/Radio-Canada's interest in HD television. In 2006, 33\% of Canadian households owned a HD television set (Canada, 2008, p. 75) and by 2014 that number had grown to 77\% (Television Bureau of Canada, 2015, p. 13). As noted by MGMT001,

The explosion of HD sets in homes was coming. We could see the curve ramping up but we still hadn't hit the 50\% point. We still didn't know when the analogue 
switch off or switch over was going to be in Canada. We didn't know which it was going to be.

In terms of delivering HDTV CBC/Radio-Canada content to Canadian HDTV-enabled households over-the-air, the quality of the North American digital over-the-air television standard named the Advanced Television Systems Committee (ATSC) was also mentioned by CBC/Radio-Canada Management. By the television delivery standards of 2012, a television signal of 19.39 megabits (quoted as 19.6 megabits below) achievable by the ATSC standard was a very high quality signal, unmatched at the time by analogue over-the-air television, analogue cable and digital cable television services (apart from, for example, Bell's nascent Fibe IPTV service). The audio-visual quality of the ATSC standard was described by members of CBC/Radio-Canada Management as follows:

(U)ncompressed ATSC is actually quite spectacular. 19.6 megabits as opposed to 12 that you get from the best cable systems. Some of them are throttling them down to 8 now. Rogers in Toronto for instance has great quality at its 12 megabits. So that was the value proposition and that was the theoretical value proposition. (MGMT001)

Better viewer experience, I guess. Nicer colours on Don Cherry's suit on a Saturday night. I'm not sure how it betters it. It's just moving along with technology at the end of the day. I think that question can be broadly interpreted in a little bit different way which is to say by being more effective with the television spectrum it did free up spectrum for additional public systems, particularly for police, ambulance and fire fighters.... The conversion to digital obviously provides a higher quality product for the viewer. The transition in our mind has always been a transition to HD digital, not SD. We did some SD in the interim period between, once the policies got all sorted out. It's always been in our head, a transition to $\mathrm{HD}$, to provide the consumer with a high quality, over-the-air product. (MGMT002)

Our over-the-air signal is the highest quality signal Canadians receive, by far. Companies like Bell TV and Shaw compress them so much I wouldn't even call it high definition TV. Number one, we provide the high watermark for digital television in Canada in production and in over-the-air delivery. If you're got a pretty wide screen system at home and you're capable of receiving an over-the-air feed, you're going to get the best quality probably in North America (MGMT003) 
With respect to the quality of HD OTA television delivery, MGMT001 notes below that the CRTC promoted using $6 \mathrm{MHz}$ of spectrum allocated for each television station to deliver a single, high-quality HD signal instead of multicasting the same $6 \mathrm{MHz}$ of spectrum to deliver multiple sub-channels at lower resolution:

What they (the CRTC) did say was that there would be a digital over-the-air, as a mode of delivering HDTV to Canadians, that it would be predominantly HD. They downplayed multicast in their decision and they articulated a reason for that because they wanted Canadians to have the benefits of high-definition, immersive television experiences. (MGMT001)

As noted above, the discourse articulated by the CRTC in terms of digital OTA television transmission in Canada (including by broadcasters) was originally about offering high quality HD signals to Canadians. This approach arguably stood at odds with access of digital OTA televisions signals since multicasting/multiplexing of digital OTA signals of lower quality would provide greater access to programming in a particularly television markets using the same amount of spectrum for a single highly resolution OTA digital television signal. In addition, as outlined in the $\mathrm{CBC} /$ Radio-Canada television-viewing household section of this chapter, the OTA households interviewed for this dissertation did not rank HD television quality as a priority, if at all.

In terms of the differences between the perceived efficient use of spectrum to broadcast analogue OTA television compared to broadcasting digital OTA television, the following lengthy quote from MGMT002 helps to outline the challenges that CBC/Radio-Canada faced with making the switch from analogue to digital OTA television delivery:

The most efficient for propagation purposes is Channels 2 to 6 meaning, at a given power the signal will go a certain distance. The problem with the Channel 2 to 6 spectrum in today's world, and in the digital world is that, part of the spectrum suffers from impulse noise. Electrical impulse noise, which are things like motors, switching power supplies, and computers and ballasts and lamps, and TVs. There's impulse noise all over the place. Impulse noise is not really visible in the analogue TV system but it will cause havoc for a 
digital TV signal. Even though we had a number of stations, because in the major markets CBC obviously was one of the original broadcasters, therefore we had some stations in the lower VHF because lower VHF was where the first stations were built and then more stuff came in upper VHF and eventually UHF once the VHF was tapped out then people got into UHF. So anyways, we didn't want to be in the Channels 2 to 6 . So that was out. We were not going to use Channels 2 to 6 . And then Channels 7 to 13 and UHF, there's a trade-off between propagation, which is good in upper VHF, and penetration which is better in UHF. The difference there means, the difference between propagation and penetration is a upper VHF signal will travel very long distances but can have problems getting inside a building, a home and apartment block, whatever, versus UHF which doesn't propagate as well, in other words you need a lot more power to make the signal go further but does penetrate better. So, if you have a transmitter in a central urban market, it's better to go UHF because you know that signal will get into people's houses and homes whereas in a more, getting back to your terrain issue, in a more rural type of environment you would want to go VHF because you get much bigger coverage for less cost. (MGMT002)

All told, the CBC/Radio-Canada Management interviews conducted for this dissertation illuminate the public broadcaster's approach to providing digital OTA television access to citizens. Four of the members of CBC/Radio-Canada Management interviewed felt that CBC/Radio-Canada's shutdown of its analogue OTA CBC/Radio-Canada television service(s) and installation of 27 digital OTA television transmitters was guided by notions of delivery efficiency. There was confidence expressed by all of the members of CBC/Radio-Canada Management interviewed that any analogue OTA television-viewing households that were beyond the reach of one of the public broadcaster's digital OTA television transmitters would be able to regain access to the same $\mathrm{CBC/Radio-Canada}$ television services via BDU, ISP, or mobile wireless delivery systems. As expressed by MGMT003, the days of digital OTA television CBC/Radio-Canada broadcasting were already numbered in 2012,

You can see the beginning of the end here. Broadcasting is either going to be a cable fed system only or, I'm talking TV not radio here, a satellite based system or an over-the-top system. I give it 10 years, personal opinion. (MGMT003) 


\section{4) A la carte}

We were pushing the Commission very hard to come up with something called a Skinny Basic which would give Canadians who were moving off of over-the-air, would give them a couple of channels, maybe a dozen channels on their basic cable package for as small amount of money, say $\$ 5$. You get 10 channels for $\$ 5$, or something like that. (MGMT004)

CBC/Radio-Canada Management's comments that embodied aspects of à la carte access to its television programming in the post-analogue realm included the viewing of CBC/RadioCanada television online, CBC/Radio-Canada's call for a 'Skinny Basic' BDU service, and Shaw's SD-only LTSS. The following members of CBC/Radio-Canada Management interviewed for this dissertation suggested that CBC/Radio-Canada's approach to post-analogue television delivery was in step with the emerging user-based, non-linear, online television viewing preferences of Canadians:

We can't continue to invest in technologies that aren't necessarily being well used. We've got to think about investing in technologies where viewers and listeners and users are going. Increasingly, Canadians are going online, they're on-demand, they're going mobile, they're going to multi-channel services like cable and satellite. The opportunity for us has been to realize that, hey, we've got to make some choices and now we can see that we have the opportunity to take some of that investment that we made in a declining technology and the costs associated with that investment and we can transfer them over to other platforms where Canadians are going increasingly. In some of the small markets in Canada, more Canadians are accessing our services online that they are using over-the-air technology. We've been given this opportunity to realize over-the-air is but one platform and it's a platform that's not really a popular one that's growing. It's a platform that's declining so it's given us a chance to, shall we say, rationalize our thinking about how to spend money within the company. (MGMT004)

In terms of moving towards the future, $\mathrm{CBC}$ is moving towards delivering its content not just on television... We're harnessing on the technology and we're trying to deliver our content in different ways, taking advantage of changes in technology and taking advantage of changes in consumer preference, of how Canadians like to receive content. We're using a number of different platforms to do that... I'm not sure what role the public broadcaster has if any in ensuring that all Canadians have high speed Internet access or what role the Corporation can do in ensuring that Canadians who may not be able to afford a package of cable services don't get left behind. Those are much broader issues that either Industry Canada or the CRTC needs to develop a strategy and a response if they identify that as a real concern within their mandate and are prepared to come up with a solution. (OTA001) 
The following members of $\mathrm{CBC} /$ Radio-Canada Management interviewed also reiterated CBC/Radio-Canada's calls that someone (not CBC/Radio-Canada) create an affordable 'Skinny Basic' BDU service (a service that the CRTC did indeed end up deciding to implement care of BDUs in 2016) which would allow Canadians to view its television services via BDUs at an affordable price:

The one thing we've been very vocal about at the CRTC is, we've been promoting for quite some time that there should be a very low cost if not free basic package for Canadian content on BDU systems. We've been promoting that. You hear it sometimes called Skinny Basic. You might hear it called low cost package. So, we've been trying to promote that idea, if you will. (MGMT002)

From the beginning, around 2005 or so, we started to push the Commission really hard on affordability, and we were one of the proponents of this thing called Skinny Basic. We were pushing the Commission to recognize that all of the benefits of the digital economy and the movement to the digital transition both television, Internet, etc, they're only going to be available to Canadians if they're going to be able to access the services and in order to be able to access the service you've got to be able to afford it. So, we were pushing the Commission very hard to come up with something called a Skinny Basic which would give Canadians who were moving off of over-the-air, would give them a couple of channels, maybe a dozen channels on their basic cable package for as small amount of money, say $\$ 5$. You get 10 channels for $\$ 5$, or something like that. We were encouraging the Commission to realize that it was affordability that would ensure that all the benefits of moving to digital, all the benefits of the broadband infrastructure would be available. (MGMT004)

Shaw's LTSS program was noted by MGMT001 as presenting another way for disconnected analogue OTA viewers to regain access to $\mathrm{CBC} /$ Radio-Canada television along with other stations, and that did not require a paid BDU subscription:

The other thing that we've done, in the context of our analogue transmitter shutdown, Shaw Direct as part of the Shaw/CanWest transaction last year has a Local Television Satellite Solution. In the context of our communicating to people that the impact of the shutting down of our analogue transmitters, we have been telling people about the availability of this Shaw option which until November 30th, if they qualify they can receive not only $\mathrm{CBC}$ and Radio-Canada but some other local services or local regional services for free until Shaw Direct's next licence term. That is a free solution for them that would probably give them more services than they had before. (OTA001) 


\section{5) Locally relevant feed(s)}

On the English side, we have television stations across the country. We have originating stations from coast to coast to coast. We have even put in a digital transmitter in Yellowknife which is not a mandatory market. In every market where we have an originating station, we are putting in a digital transmitter whether or not it's one of the CRTC's mandatory markets. Every station is treated the same way and it is digital. The same is true for Radio-Canada's television stations across Canada. (MGMT005)

Once CBC/Radio-Canada had decided that it was going to build out digital OTA television transmitter sites in markets beyond the five markets it was already serving digitally

OTA, as noted earlier, the next question according to MGMT002 was how many transmitters. As outlined by MGMT002,

When I mentioned the 80\% English mother tongue and $80 \%$ French mother tongue, that would have required 44 transmitters, of which 28 would have been English and 16 would have been French... We had eight stations on air even before the transition, that way we were simulcasting, and originally we were only planning to do seven by the deadline of August 31, and then the others to get up to 27 in the following year....We were going to do eight, seven, and then 12 . It had to do with the deadline. We would have only had 15 online by the deadline and we had, actually, we were trying to get a little bit of a delay in the transition date to do the other 12 which we didn't get so we got 'em done by the transition date.

Regardless of the final number of digital OTA transmitters, it is relevant to note that any such build-out of CBC/Radio-Canada digital OTA transmitters still did not mesh with CBC/Radio-Canada Management's philosophy of the efficient delivery of television programming that the public broadcaster held at the time. As detailed by the following members of $\mathrm{CBC} /$ Radio-Canada Management, there was little real change to the delivery of regionally relevant $\mathrm{CBC}$ /Radio-Canada television programming following the analogue OTA television service shutdown in terms of CBC/Radio-Canada distributing its television over-the-air or not: 
CBC/Radio-Canada's regional coverage has essentially stayed the same. We are still broadcasting the same number of regional TV releases in both English and French and cable and satellite DTH operators continue to retransmit these feeds to their customers. Our coverage "footprint" from these two operators remains unchanged. The OTA audience was dwindling as we approached the July 31 st date and many made the jump to cable or satellite before this date. (MGMT003)

The programming that we were creating before is still being made in all of our stations because that's the only place it was being made. Really, the only think that's happened is outside those areas in the regions, outside where we produce the programming, we've recognized that there are very few people using over-the-air and most of them are using satellite and cable. So the impact on those areas, on those regions, and I'm defining regions as outside where we have stations, the impact is negligible. It's more about... it's a delivery question rather than a programming question. We're delivering a certain programming that's going to be created whether we put in a hundred digital transmitters, a thousand digital transmitters, or just 27. The same programming is going to be created. The question is, how are you going to deliver it outside those areas where it is created? We've realized that $95 \%$ or so of Canadians outside those areas are getting that service by cable or satellite so it doesn't make to be putting in a lot of over-the-air infrastructure in those areas. (MGMT004)

MGMT002 also noted that mandatory carriage by BDUs would provide regionally relevant $\mathrm{CBC} /$ Radio-Canada television programming to its viewers:

Broadcast regulation does have specific carriage requirements for the public broadcaster. So, the number of transmitters we have does not necessarily mean the signal is not available to the Canadian public because there are provisions that says, if $\mathrm{CBC}$ has a signal in a certain region well you have to carry that signal in the region, if you're a BDU. The over-the-air footprint and what the BDUs are required to do don't necessarily have to match for the public broadcaster. (MGMT002)

\section{Summary}

All of the interviewed members of $\mathrm{CBC} /$ Radio-Canada Management noted that Canadians would continue to be able to access its television programming either by way of the 27 digital OTA television transmitters installed in 20 Canadian television markets or by other means. Two management interviewees noted that Shaw's LTSS program would provide no fee access to disconnected OTA households, and four CBC/Radio-Canada Management interviewees 
suggested that a government mandated Skinny Basic service would bring affordably-priced BDU subscriptions to households. All members of CBC/Radio-Canada Management indicated that it would not have been cost effective for the public broadcaster to have replicated its analogue OTA television service of more than 600 analogue transmitters with digital OTA television transmitters. A total cost of $\$ 20$ million to install the 27 digital OTA television transmitters was cited by MGMT002. A cost of $\$ 6$ million dollars to decommission CBC/Radio-Canada's analogue OTA television service over the period of three years was cited by MGMT003.

The significant task of decommissioning the analogue OTA television service transmitter tower sites, including environmental remediation at some sites, appears to have been more expensive than anticipated by the Corporation. CBC/Radio-Canada noted in 2015, “(d)ue to budget restrictions, much of the work anticipated for 2014-2015 has been deferred to 2015-2016" and that only 16 sites had been sold off (CBC/Radio-Canada, 2015e). While Hubert Lacroix has noted that additional funds have been secured in recent years, and that they have been directed to programming, the decommissioning of its analogue network is being held up due to budget restrictions. Since CBC/Radio-Canada noted in 2012 that $\$ 6$ million had been allocated to decommissioning its analogue OTA television tower sites (MGMT003), a delay based on budget restrictions suggests that it will take more than $\$ 6$ million to complete the job. Furthermore, if CBC/Radio-Canada saved $\$ 10$ million in just one year after shutting down its analogue OTA television service, it's clear why $139 \mathrm{CBC} /$ Radio-Canada television sites still remained on the public broadcaster's decommission list as of 2015 (CBC/Radio-Canada, 2015e).

One member of CBC/Radio-Canada Management interviewed for this dissertation noted that $80 \%$ of the population, English and French mother tongue, would be served by its 27 digital OTA television transmitters whereas two members of $\mathrm{CBC} /$ Radio-Canada 
Management interviewed noted instead that 44 digital OTA television transmitters would be required to serve the same population. For those not served by digital OTA television signals, all members of $\mathrm{CBC} /$ Radio-Canada Management interviewed argued that its programming remained available by other modes of television delivery.

Overall, the account of CBC/Radio-Canada's response to Canada's digital television transition, as detailed by the five members of $\mathrm{CBC} /$ Radio-Canada Management interviewed for this dissertation, was one of a public broadcaster keen to reduce operational overhead in order to continue operations. This cost cutting included an interest in divesting $\mathrm{CBC} /$ Radio-Canada's real estate holdings, its fleet of mobile satellite trucks, and its analogue OTA television service. More than one member of Management interviewed expressed an interest in both continuing to operate CBC/Radio-Canada's analogue OTA television service beyond 2012 and to install additional digital OTA television transmitters, but neither was deemed possible. No members of $\mathrm{CBC} /$ Radio-Canada Management indicated an interest in implementing the multiplexing of CBC/Radio-Canada's 27 digital OTA television transmitters. Instead, affordable BDU packages, such as a government mandated Skinny Basic service, were cited by all members of Management interviewed as the best way for Canadians to affordably access CBC/Radio-Canada television in the digital age. At the same time, three of the members of $\mathrm{CBC} /$ Radio-Canada Management interviewed regarded Canada's vertically-integrated BDUs with trepidation, confirming Richard Stursberg's assessment that Canada's BDUs remain "frenemies" of $\mathrm{CBC} /$ Radio-Canada. The fact that $\mathrm{CBC} /$ Radio-Canada has become even more reliant on BDUs to provide Canadians with access to its television programming suggests that the public broadcaster might need to find some better friends. 
The next chapter presents this dissertation's discussion. The discussion is approached by detailing this dissertation's Public M.A.P.S. model and by revisiting and striving to answer the four sub-research questions first posed in Chapter 1 of this dissertation. Chapter 7 also discusses the forced household migration to paid television service along with proposed areas of future research. 


\section{Summary Chart}

Table 2: Summary of Findings

\begin{tabular}{|c|c|c|c|}
\hline $\begin{array}{c}\text { CBC/Radio-Canada } \\
\text { Management }\end{array}$ & $\begin{array}{r}\text { Public } \\
\text { Siev }\end{array}$ & $\begin{array}{l}\text { Media Access Puzzle } \\
\text { e (Public M.A.P.S.) } \\
\text { Elements }\end{array}$ & $\begin{array}{c}\text { CBC/Radio-Canada } \\
\text { OTA Television-Viewing Households }\end{array}$ \\
\hline $\begin{array}{l}\text {-Analogue and digital OTA } \\
\text { television transmitters were } \\
\text { expensive to operate } \\
\text {-Opportunity cost for active OTA } \\
\text { transmitters is low } \\
\text {-Delivery via BDU and ISP costs } \\
\text { the broadcaster less }\end{array}$ & & COST & $\begin{array}{l}\text {-Analogue OTA TV had no additional } \\
\text { fee(s) for households } \\
\text {-Delivery via BDUs (not including Shaw } \\
\text { LTSS), ISPs and cell phone providers costs } \\
\text { households more and could involve overage } \\
\text { penalties. }\end{array}$ \\
\hline $\begin{array}{l}\text {-Analogue OTA television } \\
\text { signals drifted } \\
-80 \% \text { of Canadian households } \\
\text { can receive its digital OTA } \\
\text { television signals } \\
\text {-BDUs and ISPs are accessible to } \\
\text { other Canadian television- } \\
\text { viewing households. }\end{array}$ & & AVAILABILITY & $\begin{array}{l}\text {-Analogue OTA TV was accessible } \\
\text {-Digital OTA TV was inaccessible } \\
\text {-Cable and IPTV BDUs continue to be } \\
\text { inaccessible, satellite BDUs, highspeed } \\
\text { ISPs, and wireless mobile services are not } \\
\text { accessible to all households }\end{array}$ \\
\hline $\begin{array}{l}\text {-OTA digital OTA TV signal is } \\
\text { now better quality HD } \\
\text {-OTA digital OTA TV signal is } \\
\text { good until it isn't }\end{array}$ & & FUNCTIONALITY & $\begin{array}{l}\text {-Analogue OTA TV was reliable } \\
\text {-Analogue OTA TV signal was satisfactory } \\
\text {-Satellite delivery is spotty during bad } \\
\text { weather/different seasons } \\
\text {-ISP delivery is choppy/buffered }\end{array}$ \\
\hline $\begin{array}{l}\text {-BDUs must carry CBC/Radio- } \\
\text { Canada } \\
\text {-Skinny basic regulation is } \\
\text { needed }\end{array}$ & & A LA CARTE & $\begin{array}{l}\text {-Analogue OTA TV didn't require channel } \\
\text { packages/ contracts/bundles } \\
\text {-Some households only want to receive } \\
\text { CBC/Radio-Canada television } \\
\text { programming and this is not possible post- } \\
\text { analogue OTA. }\end{array}$ \\
\hline $\begin{array}{l}\text {-Access is the same post- } \\
\text { analogue } \\
\text {-CBC/Radio-Canada Radio and } \\
\text { Internet are locally relevant }\end{array}$ & & $\begin{array}{l}\text { LOCALLY- } \\
\text { RELEVANT } \\
\text { FEED(S) }\end{array}$ & $\begin{array}{l}\text {-Analogue OTA TV brought locally- } \\
\text { relevant CBC/Radio-Canada programming. } \\
\text {-Not all households that regained access } \\
\text { regained access to the same CBC/Radio- } \\
\text { Canada stations. } \\
\text {-Households can watch few live programs } \\
\text { via cbc.ca and not all shows are archived }\end{array}$ \\
\hline
\end{tabular}




\section{Chapter 7: Discussion}

This chapter responds to the four research questions posed in Chapter 1 of this dissertation, with the aim of answering the central research question of whether $\mathrm{CBC} /$ RadioCanada's operational response to Canada's 2011 digital television transition deadline has served to enhance the universality of access to its television programming in the digital age. Opportunities for future research are also discussed.

This dissertation's original research contribution is the Public Media Access Puzzle Sieve (Public M.A.P.S.) conceptual model (see Figure 3) developed through this dissertation's analysis of the research interviews conducted with analogue OTA CBC/Radio-Canada television-viewing households and members of $\mathrm{CBC} /$ Radio-Canada Management. While the Public M.A.P.S. model was developed by way of this dissertation's analysis of the research interview findings and emerged independently of other access models such as the Access Rainbow model (Clement \& Shade, 2000) and the Components of Universality model (Brevini, 2013), the Public M.A.P.S. model does serve to supplement both the Access Rainbow and Components of Universality models as detailed in Chapter 5 by accounting for the barriers to access that are encountered by analogue OTA television households attempting to maintain access to public television programming when the delivery environment shifts from one of public service broadcasting (PSB) to one of public service media (PSM).

\section{Public Media Access Puzzle Sieve (Public M.A.P.S.) model}

The findings detailed in the previous chapter help to illustrate how OTA CBC/RadioCanada television-viewing households and $\mathrm{CBC} /$ Radio-Canada Management understood and experienced the public broadcaster's operational response to Canada's digital television 
transition. As detailed in the research interviews presented, CBC/Radio-Canada's shift from analogue public service broadcasting (PSB) television delivery to digital public service media (PSM) television delivery entailed a precarious reorganization of the provision of public television delivery in Canada. Part of the challenge of this complete transfer of the provision of access to CBC/Radio-Canada television programming to Canadian BDUs, ISPs, and/or mobile wireless providers in areas of the country outside of the television markets where CBC/RadioCanada opted to install digital OTA television transmitters (for reasons detailed by members of CBC/Radio-Canada Management interviewed), was that the achievement of access to CBC/Radio-Canada television programming became more challenging for Canadian households. The difficulties reported by interviewed households with regards to the achievement of comparable post-analogue access to $\mathrm{CBC} /$ Radio-Canada television is emblematic of the fact that, even in the digitally divine (Mosco, 2004) age, television programming does not deliver itself.

The interviews conducted for this dissertation, and the subsequent analysis of the interview findings, has contributed to an understanding of public television access that include barriers to television access that betray the promise of a regulated digital television delivery system. This illumination of post-analogue barriers to CBC/Radio-Canada television access has however provided valuable data that has informed the development of this dissertation's multilayered Public Media Access Puzzle Sieve (Public M.A.P.S) model that assists in both anticipating future, and identifying existing, barriers to access to public service media (PSM) such as $\mathrm{CBC} /$ Radio-Canada television programming. 
Figure 3. Public M.A.P.S. model

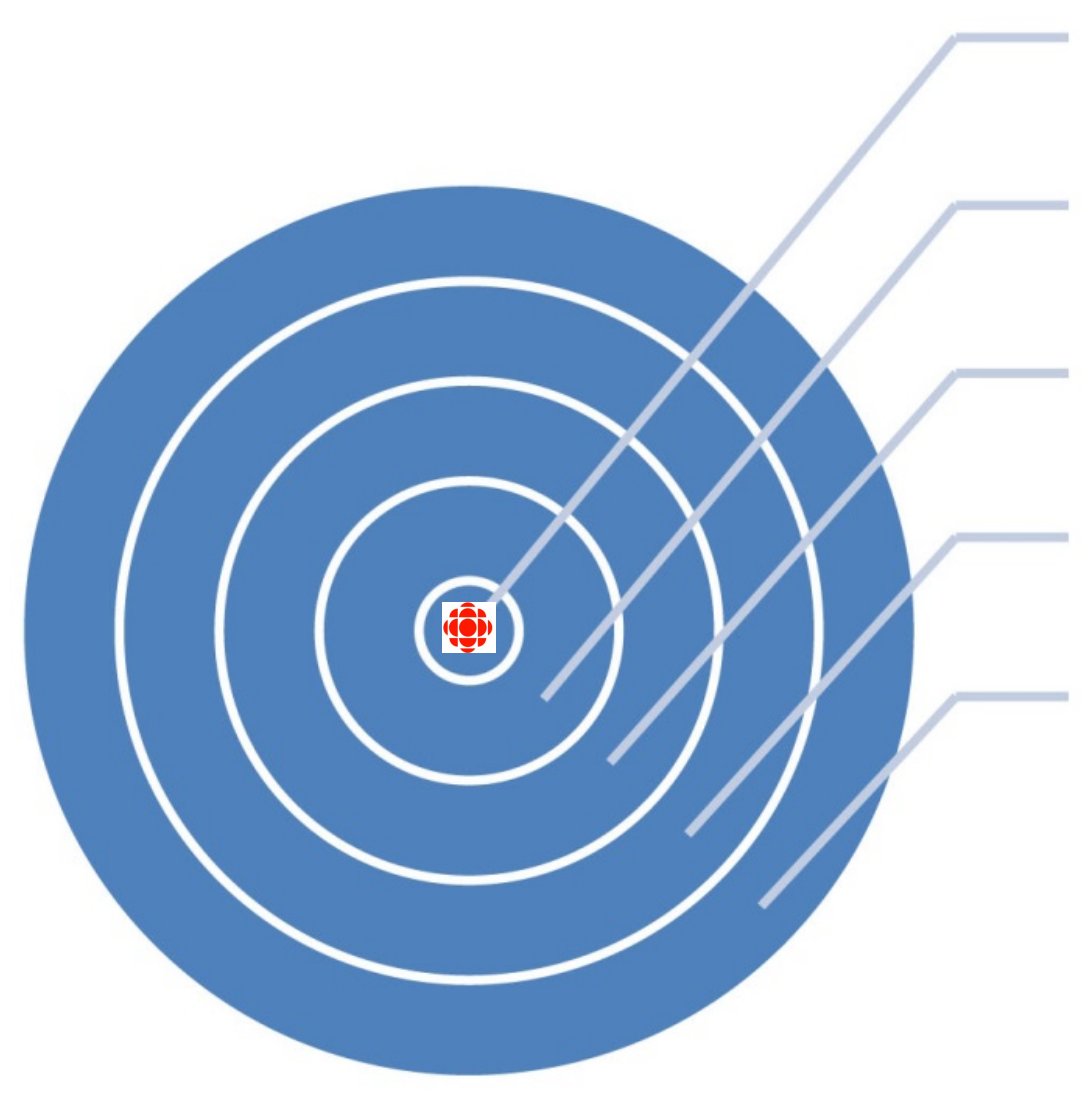

COST

AVAILABILITY

FUNCTIONALITY

A LA CARTE

LOCALLY

RELEVANT FEED(S)

As illustrated in Figure 3, the Public M.A.P.S. model depicts the access layers that each household that is striving to access $\mathrm{CBC} /$ Radio-Canada television programming must navigate in order engage with the programming. The layers are best described as sieves since the specific design of a sieve determines what may or may not pass through it to the other side.

Buried within the core of the Public M.A.P.S. model is the public service media that households are striving to access and that public service broadcasters are striving to make universally accessible (as depicted by the CBC logo located in the centre of Figure 3). As detailed in Chapter 6, when television programming is no longer distributed directly by a public service media outlet universal access to such programming is either eroded or cut off completely. A household only gains full access to the PSM, defined by the five layers of the Public M.A.P.S. 
model, once all five layers of the puzzle sieve have been permeated. If a household is unable to pass through one or more layers of the puzzle sieve, full access to PSM is not achieved.

Following the completion of the research interviews conducted for this dissertation and the subsequent coding of the findings, exposure to Clement \& Shade's (2000) Access Rainbow model (via Shade (2010), further assisted in this dissertation's analysis of the research findings that yielded the Public M.A.P.S. model. The Access Rainbow model was helpful in instilling an appreciation for the fact that not only is media access shaped by multilayered and heterogeneous layers but that the different layers of access are not linear and that their differing combinations are tied to what level of access might be achieved by a household. As noted by Clement \& Shade (2000),

It is important to challenge prevailing market-oriented rhetorics which undermine the principle of universality of services benefitting everyone. Citizens should not face a degradation of existing services until they have superior alternatives to choose from. Since the new technologies offer greater capabilities at lower costs, significant benefits can be achieved with anyone being worse off (p. 34).

Clement \& Shade (2000) also provide important access modelling advice when they note that "[a]n access model should assist in identifying where and how public action is required" (p. 4) and that their Access Rainbow model "ironically directs our attention to the many difficult challenges we face in achieving the ideal of an inclusive and supportive societal infrastructure" (p. 5).

While Benedetta Brevini's (2013) Components of universality of access model was not encountered by this dissertation until after the creation of the Public M.A.P.S. model, it served to reaffirm the layered nature to PSM in a post-analogue context and also that levels of media access vary based on the quality of access achieved on a case by case basis. Brevini articulates 
the high-stakes "struggle for PSB 2.0" (p.221) in the digital age and argues that "the principles of citizenship, universality, quality and trust as the pillars of Public Service Media when expanding in a multi-platform environment" (p. 222). Furthermore, Brevini pushes for PSB 2.0 to provide "a wider range of services" (p. 225-226) then PSB 1.0 and that in a post-analogue environment "universality of access for PSB 2.0 means that access to the networks [where PSM is to be engaged with] is guaranteed] (p. 226).

With the regards to the Public M.A.P.S. model developed by this dissertation, the first barrier to accessing public service media is cost, as shown by the inner-most layer of the Public M.A.P.S. model. For those households where the cost(s) to achieve access to PSM is not an issue, such households are able to pass directly through the cost layer by paying for whatever television delivery service(s) will provide such PSM access to the household. This might mean subscribing to a paid television service in order to gain access to programming, or subscribing to a paid Internet service provider for a connection capable of sustaining a steady connection to a video stream over the Internet. For a household where cost is not an issue, such a household could (for example), pay for their own personal fibre optic line to be run to the household if necessary such that access to PSM over the Internet might be achieved. Such households would then able to engage directly with the PSM and the household would have access. For households where cost is an issue however, such that the cost(s) to be incurred by a household to achieve such access to PSM is prohibitive and as such a household is unable to pass through the first Cost sieve layer, the remaining four sieve layers of the Public M.A.P.S. model must be tackled by the household if access is to be achieved starting with the Availability sieve layer. In other words, if a household can't pass through the cost sieve layer, the other sieve layers must be attempted by the household. Otherwise, household access to PSM is not achievable. 
The Availability sieve layer relates to the existing television delivery services that are available to a particular household. For example, if a particular household is located within the coverage area of a digital OTA television transmitter then the household might be able to receive a signal from the public broadcaster provided that the household has the hardware required to access such a broadcast television signal and if the local terrain does not interfere with signal availability. Alternatively, if a local cable or IPTV provider serves the area where a household is located then a wired connection may be available to the household and could provide PSM access. In terms of the PSM access by way of the internet, the Availability sieve layer includes whether or not the PSM content/experiences that a household is seeking is offered online. If other points of access to PSM are available, such as direct-to-home (DTH) satellite and/or fixed or mobile wireless service, such points of access would provide additional means by which to pass through the Availability sieve layer.

Once passing through the Availability sieve layer, the next sieve that the household must tackle is the Functionality sieve layer. For households where none of the above-listed points of access to PSM are available then the household does not pass through the Availability sieve layer and PSM access is not achieved. The Functionality sieve layer pertains to the audio-visual quality of PSM feed(s) that might be available to a household. In other words, the Functionality sieve layer relates to how well a household is able to maintain a connection to the PSM that is being sought out. For example, if a household is accessing PSM by way of a BDU, fixed or mobile wireless networks, or via digital OTA, the Functionality layer relates to whether or not the television signal cuts out during poor weather (referred to as rain fade), whether the signal is HD or SD, and whether the signal suffers from buffering. Additional aspects of the Functionality sieve layer includes whether or not a feed to PSM includes Closed Captioning 
and/or Descriptive Video. If the audio-visual quality of the PSM feed is insufficient to allow viewing then the Functionality sieve layer is not penetrated and access does not occur.

For households that are able to successfully pass through the Functionality sieve layer, the household must next solve the A La Carte sieve layer. The A La Carte sieve layer relates to whether or not a PSM feed can be accessed by a household without any requirement to also engage with other intermediary or bundled services. For example, if a household is required to accept other services unrelated to PSM delivery in the form of a bundle package and/or is required to first enter into a contract or rental agreement in order to gain access to the PSM then the A La Carte sieve layer maintains a barrier to PSM access.

Lastly, if a household seeking PSM access successfully passes through the Availability, Functionality, and A La Carte sieve layers, the remaining puzzle sieve layer is the Locally Relevant Feed(s) sieve layer. The Locally Relevant Feed(s) sieve layer deals with how locally relevant a PSM feed is to a household. For example, if a household located in Newfoundland and Labrador is only able to access PSM media originating from Nova Scotia, or if a household in Québec is only able to access PSM from Ontario, in both scenarios the Locally Relevant Feed sieve layer is not surpassed and full access is not achieved.

As outlined above, the Public M.A.P.S. model is comprised of Cost, Availability, Functionality, A La Carte, and Locally Relevant Feed(s) puzzle sieve layers. For households that are unable to gain access to PSM by passing through the first Cost puzzle sieve layer, such households are required to attempt to pass through each of the remaining four puzzle sieve layers in order to access PSM. For households that are also unable to pass through one or more of the Availability, Functionality, A La Carte, and/or Locally Relevant Feed(s) puzzle sieve layers, 
access to PSM is degraded at best and potentially blocked entirely at worst. The Public

M.A.P.S. model demonstrates that public service media does not deliver itself and that the need for $\mathrm{CBC} /$ Radio-Canada to enhance the provision of access to its public television programming has only heightened in the digital age rather than diminished.

\section{i) How do notions of digital technology and digital television delivery efficiency relate to citizen access to $\mathrm{CBC}$ /Radio-Canada's television programming?}

In today's world, there is no question that digital technologies and tools have vastly improved our quality of life. In every field of human achievement - from medicine to education and from space exploration to telecommunications - digital innovations and inventions are helping Canadians live better, more productive, healthier lives. (Industry Canada, 2015a, p. 2)

Former Minister of Industry James Moore's above-noted foreword to the 2015 report Digital Canada 1502.0 expounds on the benefits of digital technologies. Moore's digital mantra is reminiscent of Radiohead's 1997 ode to the computer age, Fitter Happier, only without its musings on the downside of digital. Moore seems to be describing digital as a potent elixir capable of remedying any ailment that might be afflicting Canadians. While Digital Canada 150 2.0 does acknowledge that access to communications remains an issue for Canadians in the digital age, the provision of such access according to the report is to be achieved through the offering of greater consumer choice to an already well-served public,

Connecting Canadians is about ensuring all Canadians, no matter where they live, have access to high-speed Internet services at the most affordable prices. It is also about offering Canadians more choice in their cellphone provider and the option to pick and choose the combination of television channels they want... (Industry Canada, 2015a, p. 4). 
Similarly, a September 2016 Ministry of Canadian Heritage consultation paper, Digital Content in a Digital World: Focusing the Conversation, prepared by the newly elected Liberal government of Justin Trudeau as part of Minister of Canadian Heritage Mélanie Joly’s consultation on digital Canada, reveals that Canada's new government shares the previous Conservative government's faith in the power of the "digital divine" (Mosco, 2004/2005), In a sea of choice and unrestricted access to content from all over the world, it means that Canadians take pride in their creators and actively seek out content produced by Canadians in both official languages because it's great content (Canadian Heritage, 2016, p. 2).

At first blush, the CRTC's 2015 Communications Monitoring Report appears to lend support to Digital Content in a Digital World: Focusing the Conversation's assertion that Canadians already have "unrestricted access to content" via the Internet and that "[d]igital content is easily accessed and can be consumed anywhere" (Canadian Heritage, 2016, September, p. 4). As noted in the 2015 CRTC report, "[t]he percentage of [Canadian] households with access to broadband with a download speed of at least 5 Mbps remains at 94\% (96\% with satellite)" (p. 22), with 77\% of households actually subscribing to 5 Mbps download service (p. 10). In terms of mobile wireless subscriptions, the same CRTC report notes that the number of mobile wireless subscriptions in 2013 per 100 households was 84.9 (p. 20).

However, with regards to rural broadband Internet access, the same 2015 CRTC Communications Monitoring Report adds that,

Fixed wireless is major [sic] source of broadband Internet connectivity in rural areas, where $31 \%$ of households have access available to them via fixed-wireless services but not fibre, cable, or DSL. While rural Canadians have access to services provided by satellite, capacity limitations restrict practical availability to approximately $1.5 \%$ of Canadian households. (p. 188).

The households interviewed for this dissertation that lost OTA access to CBC/RadioCanada television programming following the shutdown of the public broadcaster's analogue 
OTA television service described similar functional barriers to accessing CBC/Radio-Canada programming by way of broadband Internet, as identified in the 2015 CRTC Communications Monitoring Report. As detailed in Chapter 6 of this dissertation, 22 of the 99 households interviewed for this dissertation noted that they lacked a sufficiently highspeed fixed broadband Internet connection and 30 of the 99 households reported problems when attempting to stream video via an Internet connection.

Furthermore, successful household streaming of $\mathrm{CBC} /$ Radio-Canada television programming was restricted to streaming video on demand (SVOD) and live streaming of linear television programming that the public broadcaster had opted to make available online, presenting access barriers related to programming availability, à la carte service, and locally relevant feed(s). As such, a true replication of household access to CBC/Radio-Canada television programming online, equal to what had been previously provided by analogue OTA television delivery across both $\mathrm{CBC} /$ Radio-Canada's English and French television services, had yet to be achieved.

Beyond the individual access predicament experienced by the former analogue OTA $\mathrm{CBC} /$ Radio-Canada television-viewing households interviewed for this dissertation, the Public Media Access Puzzle Sieve (Public M.A.P.S.) model developed through the analysis of the research interviews conducted for this dissertation provides insight into how notions of digital technology and digital television delivery efficiency relate more generally to access to public television programming in the digital age. As the model illustrates, the shift from the provision of PSB to the provision of PSM entails more than a household seamlessly switching to a different mode of public service television or simply embracing new ways of engaging with 
public service television. Furthermore, the model details that when it comes to PSM delivery, public broadcasters can't expect other intermediaries to faithfully (Latour, 2005) provide households with access to public television. In other words, the Public M.A.P.S. model makes it clear that digital public media does not deliver itself.

On the matter of the level of agency that Canadian households have gained post-analogue in terms of engagement with $\mathrm{CBC} /$ Radio-Canada television programming online, enhancement of the types of participatory, user-generated, television experiences designed around active users with agency, experiences that $\mathrm{CBC} /$ Radio-Canada did offer to Canadians throughout the first half of the first decade of the second millennium via programs such as $Z e D$, were not reported by interviewed households. Instead, $\mathrm{CBC}$ /Radio-Canada's post-analogue television presence has focused on modes of digital television delivery associated with the same audience-centric narrative approach to analogue television programming used by the public broadcaster since 1952 rather than an enhanced user-centric narrative approach to digital programming based on user agency.

While $\mathrm{CBC} /$ Radio-Canada continues to refrain from pay-walling domestic online access to its CBC Television and Télévision de Radio-Canada conventional television programming that it opts to make available online, with the exception of certain television programming made available on Tou.tv, 15 of the $99 \mathrm{CBC} /$ Radio-Canada television-viewing households interviewed for this dissertation expressed concern about accessing CBC/Radio-Canada television programming online due to anticipated data overage/bandwith fees. Such interviewed households expressed concerns related to the household's ability to view as much CBC/Radio-Canada programming per month as desired without concerns related to monthly usage caps currently common to services offered by Canadian ISPs and mobile wireless providers. 
As detailed by the research interviews featured in Chapter 6 of this dissertation, notions of digital technology and digital television delivery efficiency that replaced analogue OTA television access with access by way of broadband Internet and mobile wireless service as embraced by $\mathrm{CBC} /$ Radio-Canada and the Canadian government have resulted in both degraded household access to linear $\mathrm{CBC} /$ Radio-Canada television programming (when compared to the access that was provided to interviewed households in the linear analogue OTA television era) and a lackluster execution of non-linear digital television access in terms of CBC/RadioCanada's provision of opportunities for meaningful user agency by households that continue to remain relegated to their twentieth century roles as passive analogue television audiences rather than active digital television users.

\section{ii) What role did CBC/Radio-Canada's analogue over-the-air (OTA) television transmitters/retransmitters play in the provision of citizen access to $\mathrm{CBC} /$ Radio-Canada television programming prior to their shutdown?}

Chapter 1 of this dissertation presents Canada's Broadcasting Act as the guiding piece of legislation that articulates the aims and objectives of the country's regulated radio and television broadcast system. The Act states that Canada's publicly-owned electromagnetic radio spectrum is to be used to "provide a public service" directed at "the maintenance and enhancement of national identity and cultural sovereignty" (Section 3. (1) (b)). As detailed in Chapters 2 and 5, the work of Raboy (1990/1996/2010), Mosco (1989/2003/2004/2009), McChesney (1999/2013), Taylor (2009/2013/2016), and others helps to outline the reasons why Canada's broadcasting system has such stated aims. In addition, the Broadcasting Act designates the Canadian Broadcasting Corporation ("the Corporation") as national public broadcaster and specifies what the broadcaster's radio and television services "should" entail. 
With regards to television programming offered by the Corporation, such content can be evaluated based on its fulfillment of particular programming objectives (English and French programming of equal quality, the production of multicultural and multiracial programming, contribution to national consciousness and identity) and the television programming's perceived quality, popularity with audiences, and how many nominations and awards such programming garners. Access to the Corporation's television programming can be evaluated through application of access models such as Clement and Shade's (2000) Access Rainbow, Brevini's (2013) components of universal access pyramid, and, as articulated by way of this dissertation's findings, the Public Media Access Puzzle Sieve (Public M.A.P.S.) model.

The Broadcasting Act, forged in an era of analogue television broadcasting, does not quantify what exact level of access is deemed as sufficient when assessing access to the Corporation's television programming. The most recent 1991 version of the act only notes that programming is to "be made available throughout Canada by the most appropriate and efficient means and as resources become available for the purpose" (3. (1) (m) (vii). However, as outlined in the digital divide literature discussed earlier in this dissertation, assessing how television programming created by the Corporation is being made accessible in the twenty-first century is a broader question than simply what television signals are available to Canadian households.

In terms of answering the research question of what role $\mathrm{CBC} /$ Radio-Canada's analogue OTA television service played in the provision of access of $\mathrm{CBC} /$ Radio-Canada television programming to Canadian households, this dissertation identified differing assessments of the service between the interviewed OTA CBC/Radio-Canada television-viewing households and the interviewed members of $\mathrm{CBC} /$ Radio-Canada Management. These differing accounts of the 
role that analogue OTA television service played in the provision of access to CBC/RadioCanada programming provide a more nuanced accounting of both the demise of the public broadcaster's analogue OTA television service in 2012 and CBC/Radio-Canada's approach to the post-analogue delivery of its television programming.

Three quarters of the OTA CBC/Radio-Canada television-viewing households interviewed for this dissertation reported that the cost of CBC/Radio-Canada's analogue OTA television service had historically played a role in household's access to CBC/Radio-Canada television programming and was continuing to do so right up until its shutdown. Not only did the analogue OTA television service satisfy the availability element of the Public M.A.P.S. model, thanks to the more than 600 analogue television transmitters/retransmitters that the Corporation operated until the end of July 2012 in addition to the analogue transmitters operated by private $\mathrm{CBC} /$ Radio-Canada affiliate stations, but the analogue OTA television service also satisfied other elements of access identified by this dissertation. While CBC/Radio-Canada's analogue OTA televisions service was reported by interviewed households as providing access to CBC/Radio-Canada television programming at no additional cost(s) for the household, it also provided households with à la carte access to $\mathrm{CBC} /$ Radio-Canada television programming without requiring the household to also subscribe to other televisions stations, functioned at a satisfactory level as a mode of television delivery, and provided locally relevant feed(s) to the households interviewed.

In contrast, all members of CBC/Radio-Canada Management interviewed for this dissertation reported that its analogue OTA television service was no longer playing a key role in the provision of access to its television programming. Management's main reasoning for this assessment was based on a shared understanding that a low number of Canadian households 
were understood to be watching $\mathrm{CBC} /$ Radio-Canada television programming directly from a local analogue transmitter/retransmitter. Since the number of analogue OTA television viewing households was understood to be low, Management was unanimous in its view that the analogue OTA television service was not deemed to be offering a critical mass of benefits that would have justified the cost of continuing to operate the service. As such, CBC/Radio-Canada Management's critique of its analogue television service was centred on the cost effectiveness element of the Public M.A.P.S. model, as directly incurred by the Corporation.

Overall, members of CBC/Radio-Canada Management interviewed for this dissertation did not question whether its analogue OTA television service was providing a minority of household with access to CBC/Radio-Canada television-viewing programming. Management's critique of the analogue OTA television service was instead based on there not being enough Canadian households that watched its analogue OTA television service outside of mandatory digital television markets to justify the ongoing expense incurred by the public broadcaster to continue to offer the service. CBC/Radio-Canada Management's critique was not that its analogue OTA television service was no longer providing television access to Canadian households but that it was no longer cost effective to continue to operate the service.

Based on the interviews conducted, OTA CBC/Radio-Canada households interviewed for this dissertation attached a higher level of importance to the Corporation's OTA television (analogue and digital) service than did the interviewed members of CBC/Radio-Canada Management. Management's critique of analogue OTA television delivery outside of mandatory digital television markets also reflects CBC/Radio-Canada's critique of OTA television delivery in general. As noted earlier in this dissertation, $\mathrm{CBC} /$ Radio-Canada argued for some time that OTA television delivery of any kind, analogue or digital, is no longer regarded by the 
Corporation an appropriate and efficient mode of television delivery (particularly in lower populated areas of the country).

The analogue OTA CBC/Radio-Canada television-viewing households interviewed for this dissertation did not speak to geographic location or population density as a valid determinant of whether or not a household might be eligible to receive OTA access to the public broadcaster's television programming. Such a discussion brings attention to the matter of which citizens are deemed to be worthy of receiving access to the services of Canada's public broadcaster by way of publicly owned infrastructure that provides household access to public television programming without the need for a paid television subscription service. Historically, the placement of the Corporation's analogue OTA television transmitters/retransmitters was not based on factors such as household income, a household's television programming preferences, or the availability of other communications services to a household. Instead, as detailed in Chapter 2, the Corporation's original six analogue television transmitters were built in metropolitan areas (Montreal, Toronto, Ottawa, Winnipeg, Vancouver, and Halifax) that had higher population densities than other areas of the country. However, the Corporation's original analogue transmitter plan was always understood as representing a starting point with additional analogue OTA coverage in other regions to be provided in the future. While such extended coverage was initially provided by way of privately-owned $\mathrm{CBC} /$ Radio-Canada affiliate stations that aired the public broadcaster's television programming, by the mid-1980s the Corporation had built more than 600 publicly-owned OTA television transmitters/retransmitter sites and continued to purchase previously privately-owned CBC/Radio-Canada affiliated analogue OTA television stations (as recently as 2008) in order to provide additional Canadian households with OTA access to the public broadcaster. 
While the CRTC's final digital television transition policy that called for the use of digital OTA television transmitters by broadcasters operating within the national capital region, provincial capitals, and in television markets of 300,000 or more residents was comparatively ambitious when compared to the start of analogue OTA television broadcasting in Canada, unlike the start of analogue OTA television in Canada, the Commission's digital OTA television transmitter placement plan was presented as the be-all and end-all of Canada's digital television transition. The CRTC's digital television transition plan neither required nor discussed any future requirement for broadcasters to construct additional digital OTA television transmitters in other areas of the country.

As for the Corporation's operational response to the Commission's final digital television transition plan, $\mathrm{CBC} /$ Radio-Canada introduced a new eligibility determinant for post-analogue OTA household access to its television programming by way of publicly-owned infrastructure. The Corporation's final digital television transition plan was limited to the installation of 27 digital OTA transmitters in the 20 Canadian television markets where it had television stations originating television programming in English and/or French. As such, while CBC/RadioCanada's custom digital OTA transmitter placement plan was dictated in part by the location of the Corporation's analogue transmitters first installed in higher populated metropolitan areas of the country such as Montréal and Toronto in the 1950s, CBC/Radio-Canada's digital OTA television transmitter placement plan was equally guided by location of tower sites established for analogue transmitters installed more recently in non-mandatory digital markets with comparatively fewer residents such as Yellowknife and Rimouski. 


\section{iii) What role does $\mathrm{CBC}$ /Radio-Canada's current network of digital over-the- air (OTA) television transmitters play in the provision of citizen access to $\mathrm{CBC}$ /Radio-Canada television programming by Canadian television-viewing households?}

Almost all (93 of 99) CBC/Radio-Canada analogue OTA television-viewing households interviewed for this dissertation were unable to regain OTA access to $\mathrm{CBC} /$ Radio-Canada television programming following the shutdown of the public broadcaster's analogue OTA television service and the completion of the installation of its digital OTA television service. As such, the role that $\mathrm{CBC} /$ Radio-Canada's digital OTA television transmitters played in the ability of interviewed households to access the public broadcaster's television programming was minimal. However, by reflecting upon lost OTA television access to CBC/Radio-Canada, OTA households interviewed were able to make visible elements of access to public broadcasting by way of publicly owned infrastructure previously provided in the Corporation's analogue OTA television era but that were neither extended into the digital era by way of $\mathrm{CBC} /$ Radio-Canada's digital OTA television transmitters nor by way of other modes of household of television delivery hyped to be the future of television delivery such as television delivery by way of ISP or mobile wireless telecom provider.

In terms of the six interviewed households that were eventually able to regain OTA access to $\mathrm{CBC} /$ Radio-Canada television programming by way of the public broadcaster's digital OTA transmitters, reflections related to the households' newly digital OTA television reception were limited to an acknowledgement that the household once again had OTA television access to $\mathrm{CBC} /$ Radio-Canada. As such, the switch to digital OTA for the six households did not represent an enhancement of their access to the public broadcaster but was rather a continuation of the household access (no better, no worse) that had been previously provided by the public broadcaster's defunct analogue OTA television service. 
In terms of the use of digital OTA broadcasting for the provision of citizen access to $\mathrm{CBC} /$ Radio-Canada television programming by way of publicly-owned spectrum, an opportunity that exists for $\mathrm{CBC} /$ Radio-Canada to enhance household access to its television programming that did not exist in the analogue transmitter era involves the use of digital multiplexing. As previously noted, the ATSC digital OTA television broadcast standard now in use in Canada, the United States, Mexico, and elsewhere allows for the same $6 \mathrm{MHz}$ band of spectrum previously allocated to carry a single analogue OTA television broadcast signal to be used to deliver multiple digital television broadcast signals, along with audio signals and other programming information, through a process known as multiplexing. This improvement in spectral efficiency provides an opportunity for ATSC television broadcasters, including CBC/Radio-Canada, to provide additional television services OTA via each swath of $6 \mathrm{MHz}$ spectrum allocated per digital OTA television transmitter. However, $\mathrm{CBC} /$ Radio-Canada has so far declined to implement the use of multiplexing for its 27 digital OTA television transmitters (apart from the previously mentioned ATSC Mobile TV testing that ended in 2012). This approach by the Corporation illustrates a contradiction in CBC/Radio-Canada's embrace of digital television programming delivery efficiency since it is not taking full advantage of the opportunities made possible by the ATSC digital broadcast standard. Instead, CBC/Radio-Canada is largely using its 27 digital OTA television service to deliver its television programming in the exact same way that it used its analogue OTA television service (with the exception that it now offers its programming OTA in HD).

For households interviewed for this dissertation, access to CBC/Radio-Canada television feed(s) as identified by the Public M.A.P.S. model is the priority rather than concerns related to broadcast signal quality. Furthermore, on the topic of signal quality, the multiplexing of $6 \mathrm{MHz}$ 
of spectrum to deliver multiple television sub-channel feeds instead of just one television feed will still permit the broadcast of $\mathrm{HD}$ feeds to $\mathrm{CBC} /$ Radio-Canada audiences. As noted in a report prepared for Industry Canada on the topic of Canada's future spectrum needs, for a digital television broadcaster that is using multiplexing,

The usual configuration is for a multiplexer to accommodate a single HDTV stream, plus one or two extra SDTV programs. Up to 6 SD (standard definition) TV programs could be accommodated by a $6 \mathrm{MHz}$ OTA channel operating a $19.3 \mathrm{Mbps}$ channel.

(Industry Canada, 2012, p. 91).

As detailed above, it is clearly possible that $\mathrm{CBC} /$ Radio-Canada could implement multiplexing and still continue to broadcast a single HD feed from each of its 27 digital OTA television transmitters along with at least one SD subchannel. Global Television's CIII-DT in Canada and PBS affiliate WNED-DT in the United States are just two examples of digital OTA television broadcasters that are currently using ATSC multiplexed configurations to broadcast one HD channel and one SD subchannel from their transmitters. Such use of digital OTA television multiplexing by $\mathrm{CBC} /$ Radio-Canada would assist the public broadcaster in improving citizen access to its television programming without the risk of degrading the digital OTA television HD signal currently being broadcast by each $\mathrm{CBC} /$ Radio-Canada digital transmitter.

While public broadcasters around the world have been transitioning from analogue OTA television broadcasting to digital OTA television broadcasting, the Australian, U.S., and U.K. public television digital transition examples outlined in Chapter 3 of this dissertation help to reveal that CBC/Radio-Canada's custom response to Canada's digital television transition had less to do with enhancing the provision of television access to Canadian households when compared to the digital television transitions completed elsewhere. CBC/Radio-Canada's custom response to Canada's digital television transition (itself primarily focused on the clearing 
of the $700 \mathrm{MHz}$ band of spectrum and less so on improving citizen access to OTA television broadcasting), represents the most egregious manifestation of how Canada's overall approach to the digital delivery of television in the country is at odds with citizen access to CBC/RadioCanada television programming by way of publicly owned infrastructure and spectrum capable of eluding the documented barriers to access created by BDU, ISP, and mobile wireless television delivery.

Significantly (and rather ironically) for $\mathrm{CBC} /$ Radio-Canada Management and OTA $\mathrm{CBC} /$ Radio-Canada television-viewing households alike, the newly relocated band of $700 \mathrm{MHz}$ spectrum previously used for television delivery is no longer necessarily associated with the delivery of television in the country. Such reallocated spectrum provided by Canada's digital television transition overwhelmingly now falls outside of the purview of the Broadcasting Act and its related regulatory television delivery measures and is thus beyond the reach and use of non-vertically integrated television broadcasters such as the Corporation. Unlike Canadian broadcasters and BDUs, Canadian ISPs and mobile wireless telecom providers do not currently have any responsibility to create or deliver $\mathrm{CBC} /$ Radio-Canada, or any CanCon television programming for that matter, to their subscribers.

In terms of the role that $\mathrm{CBC} /$ Radio-Canada's digital television transmitters currently play in making the public broadcaster's television programming available to Canadian households, members of $\mathrm{CBC} /$ Radio-Canada Management interviewed for this dissertation advised that its digital transmitters play a tertiary role in the provision of household access to its programming. Members of $\mathrm{CBC} /$ Radio-Canada Management interviewed advised that the public broadcaster's operation of digital OTA television transmitters is not based primarily on the notion that households are accessing its programming over-the-air. Instead, Management advised 
that one of the main reasons why the public broadcaster currently operates digital OTA television transmitters in 20 Canadian television markets is so that the public broadcaster can continue to compete for advertising revenue. Since the Canadian television advertising market and the rights of television broadcasters to sell adverting spots in certain markets continues to be based on the signal footprint of OTA television transmitters, members of Management interviewed advised that the Corporation needed to maintain the operation of OTA television transmitters in markets where it hoped to continue to sell advertising. The selling of $\mathrm{CBC} /$ Radio-Canada television commercial spots to advertisers would then provide the Corporation with the revenue needed to supplement its annual federal funding allocation shortfalls each year and to continue operations. By continuing operations as a public broadcaster, $\mathrm{CBC} /$ Radio-Canada television would retain mandatory carriage on the basic service packages provided by the Canadian BDUs that the majority of Canadian households rely on for access to television programming (including $\mathrm{CBC} /$ Radio-Canada programming).

In contrast, the OTA CBC/Radio-Canada television-viewing households interviewed for this dissertation that lost access to the public broadcaster following the completion of its response to Canada's digital television transition continued to value OTA television transmitters as direct means by which to access the public broadcaster's television programming. However, since $\mathrm{CBC} /$ Radio-Canada declined to install any digital OTA retransmitters as part of its approach to Canada's digital television transition, households located outside of markets with $\mathrm{CBC} /$ Radio-Canada originating stations did not receive digital OTA access to the public broadcaster.

The CBC/Radio-Canada digital television transmitter placement strategy outlined in this section illustrates how access to the public broadcaster's television programming has been 
disrupted following Canada's digital television transition. In the analogue era, the provision of household access to $\mathrm{CBC}$ /Radio-Canada care of BDUs requiring them to include $\mathrm{CBC} /$ RadioCanada stations in English and in French in their basic television packages provided Canadians the option of either BDU access or OTA access to the public broadcaster's television programming in many areas of the country. However, once CBC/Radio-Canada shut down its remaining 607 analogue OTA television transmitters in favour of 27 digital OTA television transmitters, the same system of $\mathrm{CBC} /$ Radio-Canada television delivery by way of BDU basic carriage no longer also included the additional benefit of household access to CBC/RadioCanada television programming by way of actual OTA transmitters (for households located beyond the reach of its 27 digital OTA television transmitters). CBC/Radio-Canada's approach to digital OTA television delivery has thus resulted in a delivery scenario where households that previously turned to the public broadcaster's actual OTA transmitters for access to the public broadcaster no longer had such an option.

\section{iv) Did Canada's reallocation of the publicly owned $700 \mathrm{MHz}$ electromagnetic radio spectrum associated with the country's 2011 digital television transition serve to enhance citizen access to $\mathrm{CBC}$ /Radio-Canada television programming?}

The $\$ 5.27$ billion question is whether Canada's regulatory approach to the country's digital television transition was worth it. The ministry formerly named Industry Canada clearly indicated that it felt that it had been. As Industry Canada noted in 2014, the $\$ 5.27$ billion raised from Canada's $700 \mathrm{MHz}$ auction represented "revenue for Canadians" and the revenue would be "deposited in the Consolidated Revenue Fund and reinvested in priorities that matter to Canadians" (Industry Canada, 2015c). While the promise that the $700 \mathrm{MHz}$ auction revenue would be invested in "priorities that matter to Canadians" was rather vague, it would not be 
unreasonable to expect that at least a portion of the revenue would be reinvested back into the same regulated television broadcast system from which the spectrum auction revenues were harvested, specifically investment in publicly-owned television delivery infrastructure. Such a direct reinvestment into Canada's television broadcast system has yet to be reported.

While the Conservative government at the time was certainly pleased with the earnings that flowed from its 2014 auctioning of the $700 \mathrm{MHz}$ of spectrum previously used for analogue OTA television broadcasting, this dissertation's focus is also concerned about whether this change served to enhance the state of Canada's broadcasting system as a public service. As noted in Section 3 of the Broadcasting Act,

The Canadian broadcasting system, operating primarily in the English and French languages and comprising public, private and community elements, makes use of radio frequencies that are public property and provides, through its programming, a public service essential to the maintenance and enhancement of national identity and cultural sovereignty. (3 (1) (b))

Furthermore, the Act states,

A range of broadcasting services in English and in French shall be extended to all Canadians as resources become available. (3 (1) (k))

Lastly, in reference to the role of $\mathrm{CBC} /$ Radio-Canada, the Act states, The Canadian Broadcasting Corporation, as the national public broadcaster, should provide radio and television services incorporating a wide range of programming that informs, enlightens and entertains (3 (1) (m))

All three of the above-noted excerpts from the Broadcasting Act describe broadcasting as a public service. With regards to television broadcasting, any licensed public, private, or community broadcasters operating in Canada operates on the premise that they are providing 
some form of public service to Canadians as detailed in each broadcaster's condition of licence. This expectation of public service commenced in the age of analogue broadcasting and continues in the digital age of broadcasting.

Tellingly, the Government of Canada did not opt in 2011 to end the use of publiclyowned spectrum to provide OTA television broadcasting to Canadians. On the contrary, it selected OTA digital television as the television delivery medium best suited to bring HD television programming to Canadians due to its superior access qualities. The stated aims of Canada's digital television transition included the generation of revenue for the government from the $700 \mathrm{MHz}$ spectrum auction, the clearing of spectrum within mandatory digital markets for wireless broadband use, improved picture and sound quality, the option of multiplexing for markets with digital OTA television delivery, and the clearing of spectrum for dedicated safety and emergency uses.

Beyond these desired aims, Canada's digital television transition also served as a catalyst for $\mathrm{CBC} /$ Radio-Canada to take the bold action of shutting down more than 600 of its analogue OTA television transmitters. Such a move was not a stated aim of Canada's digital television transition. While the portions of $700 \mathrm{MHz}$ spectrum auctioned off by Industry Canada have been put to other use, such a LTE Advanced wireless services for mobile wireless communications, it's unclear what, if any, use is being made of the spectrum located outside of the $700 \mathrm{MHz}$ band that $\mathrm{CBC} /$ Radio-Canada had previously used for analogue OTA television broadcasting. Since most of CBC/Radio-Canada's analogue OTA television transmitters were attached to "towers in the middle of nowhere" (Stursberg, 2012, p. 266), it is likely that the spectrum previously allocated for use by such transmitters (outside of mandatory digital television markets and outside of the $700 \mathrm{MHz}$ band) is no longer being used for anything and instead lays fallow. 
While the CRTC's digital television transition regulations did not require $\mathrm{CBC} /$ Radio-Canada to vacate such spectrum outside of mandatory digital markets (unless the analogue OTA transmitters were operating at full-power on channels 52 to 69), Canada's digital television transition nonetheless resulted in $\mathrm{CBC} /$ Radio-Canada abandoning spectrum that has likely not been put to other use. Furthermore, Ontario educational broadcaster TVO, seemingly inspired by $\mathrm{CBC}$ /Radio-Canada's lead, also shut down its own analogue OTA television transmitters in 2012, even after stating a year earlier that it would keep more than a dozen of its full power analogue OTA television transmitters and more than 100 of its low power analogue transmitters located outside of mandatory digital markets operational (TVO, 2012 April).

The consensus amongst Canadian policymakers and media alike, include the previously mentioned assessment by Jennifer Ditchburn that the 2011 digital television transition was a nonevent, and Minister of Industry James Moore's praise of those involved in the transition and the clearing of $700 \mathrm{MHz}$ band of spectrum, was that Canada's digital television transition of 2011 was a success. However, these assessments of measuring the transition's success had little to do with the delivery of digital OTA television service, particularly $\mathrm{CBC} /$ Radio-Canada television service, to Canadians. As noted earlier, the Treasury Board of Canada Secretariat bestowed a 2012 Public Service Award of Excellence upon Canada's digital television transition team comprised of members of Canadian Heritage, the CRTC, Industry Canada, and others. As part of the Public Service Award announcement, the Treasury Board made the following claims about Canada's digital television transition, claims that the OTA CBC/Radio-Canada televisionviewing households interviewed for this dissertation may not agree with:

In the end, the transition to digital television was a resounding success. The team devised a seamless process that was implemented at a fraction of the cost of human resources used by other countries in making similar transitions. New and innovative tools were employed, the private and public sectors worked in partnership, and citizens were offered the 
personalized support they needed. This team's outstanding work in achieving a smooth and cost-effective move to digital television in Canada is a source of pride for the Public Service of Canada. (Canada, 2012)

While early discussion of Canada's digital television transition included mention of improved television delivery to Canadian households, primarily on the basis of signal quality (CRTC, 2009), discussion of the benefits of digital OTA television broadcasting were minimal leading up to, and following, the analogue OTA shutdown. As noted by then Canadian Heritage Minister James Moore in the preface of a 2012 CRTC performance report, Canada's digital television transition, according to Moore, had "helped ensure that Canadians can enjoy the benefits of digital television, while also freeing up much-needed spectrum for advanced wireless services at a minimal cost to taxpayers" (CRTC, 2012a, p. 1). The same report also made it very clear that the government was of the opinion that Canada's digital television transition had well served Canada's national television system when it stated that "over-the-air broadcasters successfully managed...the analog-to-digital transition to ensure access for all Canadians" and that "all over-the-air broadcasters in rural areas have alternate solutions in place to ensure access to digital signals" (CRTC, 2012a, p. 16).

In contrast to the Treasury Board's accounting of Canada's digital television transition, critics of the transition such as NDP MP Charlie Angus alternatively described the mixed execution of Canada's analogue to digital television transition as a "hodgepodge" (Canada, 2011, March 2) effort. If Canada's approach to completing its digital television transition was lacking in ambition in terms of the establishment of mandatory digital television markets, CBC/Radio-Canada's reaction to Canada's digital television transition was even less ambitious in terms of enhancing post-analogue household access to CBC/Radio-Canada television programming. In terms of answering the question of whether Canada's reallocation of the 700 
$\mathrm{MHz}$ band of spectrum served to enhance access to $\mathrm{CBC} /$ Radio-Canada television programming following Canada's digital television transition, a review of the post-analogue OTA availability of CBC/Radio-Canada television programming in the cities of Fredericton, Yellowknife, and Windsor (ON) helps to provide insight.

\section{Fredericton's CBAT-TV CBC Television transmitter}

CBC Television's CBAT-TV analogue OTA television transmitter located in Fredericton, New Brunswick, provided OTA television service to Fredericton, Saint John, and other surrounding communities leading up to Canada's digital television transition. In March 2011, the CRTC denied CBC/Radio-Canada's original plan to transition its CBAT transmitter to digital since the digital transmitter that was to be placed in Fredericton was not anticipated to also provide OTA coverage to Saint John (CRTC, 2011b). In its decision, the CRTC noted that "broadcasters should to the greatest extent possible ensure that Canadians do not lose access to free OTA television services as a result of the transition to OTA digital transmission" (CRTC, 2011b).

In response, $\mathrm{CBC} /$ Radio-Canada revised its plan and advised that it would continue to operate its analogue OTA retransmitter in Saint John, at a lower power, in order to serve Saint John after converting the Fredericton transmitter to digital. The CRTC approved this revised approach by CBC/Radio-Canada in August 2011 (CRTC, 2011e), even though Saint John was included in the CRTC's final list of mandatory markets for conversion to digital television, noting that the "proposal was the only viable way to continue to provide over-the-air coverage to Saint John" and that this approach would "allow the Commission to review the service provided to Fredericton and Saint John when the CBC's applications for licence renewal are considered in 2012" (CRTC, 2011e). However, on July 17, 2012, ahead of CBC/Radio-Canada's (by then postponed) licence renewal hearing, the CRTC approved CBC/Radio-Canada's final request to 
amend all of its television licences to remove any mention of the use of analogue OTA television transmitters (CRTC, 2012c). The following explanation given by the CRTC in its decision to approve the licence amendment provides insight into how Canada's digital television transition failed to provide safeguards to prevent the degradation of household access to $\mathrm{CBC} /$ Radio-Canada television programming,

[L]icences, such as those held by the $\mathrm{CBC}$, are authorizations to broadcast, not an obligation to do so. In other words, while the Commission has the discretion to refuse to revoke broadcasting licences, even on application from a licensee, it cannot direct the $\mathrm{CBC}$ or any other broadcaster to continue to operate its stations and transmitters. (CRTC, 2012c, paragraph 10)

\section{Yellowknife's CFYK-TV CBC Television transmitter}

CBC Television's digital OTA transmitter installed in the northern territorial capital of Yellowknife, Northwest Territories on July 31, 2012 was the last digital OTA television transmitter that $\mathrm{CBC} /$ Radio-Canada built as part of its response to Canada's digital television transition. Yellowknife's CBC Television transmitter provides digital OTA access to CBC Television programming to the residents of Yellowknife and surrounding communities in the languages of "Cree, Inuktitut, Inuvialuktun, Dene, Tlicho, Chipewyan, North Slavey, South Slavey, and Gwich'in, as well as in English and French" (CRTC, 2013). After Yellowknife, $\mathrm{CBC} /$ Radio-Canada declined to install any additional digital television transmitters in other Canadian television markets beyond the 20 television markets served by its 27 OTA digital television transmitters.

While the residents of Yellowknife now benefit from digital over-the-air access to CBC Television, that the city was fortunate enough to end up with a digital transmitter was not based on the CRTC's mandatory digital television market regulation or on any anticipated direct viewership from the transmitter. Yellowknife was removed from the CRTC's list of mandatory 
digital television markets in March of 2011 (along with Whitehorse and Iqaluit) but it still received a digital $\mathrm{CBC}$ Television OTA transmitter based on CBC/Radio-Canada's final digital television transition policy of installing digital OTA television transmitters at stations where it originated television programming. As was also the case elsewhere in the country, $\mathrm{CBC} /$ RadioCanada's decision to install a digital CBC Television transmitter in Yellowknife was not based on anticipated OTA reception by television-viewing households. Ironically, the reason the residents of Yellowknife are now able to access CBC Television digitally over-the-air without the need to subscribe to a paid television service is a result of the Corporation's custom digital transmitter policy fixated on the delivery of its programming to Canadians by way of BDUs. Yellowknife households are able to watch CBC Television over-the-air due to the Corporation's preference of providing Canadians with access to its television programming created by originating stations and distributed by BDUs rather than directly from an area OTA transmitter.

Yellowknife's circuitous route to securing a digital OTA CBC Television transmitter is representative of Canada's and CBC/Radio-Canada's approaches to the provision of $\mathrm{CBC} /$ RadioCanada television access following the reallocation of Canada's $700 \mathrm{MHz}$ band of spectrum. CBC/Radio-Canada's complete shutdown of its analogue OTA television services, and partial transition to digital OTA television based on originating station status, speaks not only to its operational philosophy as a twenty-first century public television broadcaster but also to the ability of Canada's entire television broadcast system to serve the public interest with regards to the preservation of communication rights in the country in the digital era.

\section{Windsor's CBEFT-TV Télévision de Radio-Canada transmitter}

Télévision de Radio-Canada commenced OTA broadcasting in Windsor, Ontario in 1976, the day before the start of the Montréal Summer Olympics (Canadian Communications Foundation, 2011). After serving as a retransmitter of television feeds from a variety of 
Télévision de Radio-Canada stations over the years, including Montréal (CBFT-TV) and Ottawa (CBOFT-TV), in 2010 the CRTC approved CBC/Radio-Canada's request to amend its licence to assign CBEFT-TV as a rebroadcaster of CBLFT-TV (CRTC, 2010b).

By August 2011, the CRTC approved, as part of Broadcasting Decision CRTC 2011-494 CBEFT-TV to continue to broadcast over-the-air in analogue until August 31, 2012. However, as previously noted, on April 4, 2012 CBC/Radio-Canada submitted a "Notice of Decommissioning of the Corporation's Analogue Television Rebroadcasting Transmitters" to the CRTC, advising that " $[\mathrm{t}]$ he Corporation has determined it is no longer possible to continue operating its analogue television retransmitters", since the "Federal budget released 29 March 2012 significantly reduced CBC/Radio-Canada's Parliamentary appropriation”, and that “CBC/Radio-Canada will therefore cease transmitting from all analogue television rebroadcasting transmitters on July 31, 2012" (CRTC, 2012b). While Windsor, ON was included in the CRTC's final list of markets designated for mandatory conversion to digital television, CBC/Radio-Canada declined to convert CBEFT to digital OTA as per the Corporation's originating station policy.

Comments submitted to the CRTC in 2012 regarding how this shutdown would affect the residents of Windsor, Ontario, specifically included comments from the City of Windsor and the Commissioner of the Office of Official Languages. In the comments from the Office of Official Languages, Commissioner Graham Fraser expressed concern related to "the potential impact of decommissioning analogue over-the-air transmissions on official language minority communities (OLMCs)" (Commissioner of Official Languages, 2012, June 18). With regards to CBEFT-TV specifically, Fraser noted,

The Francophone community in Windsor, Ontario, has taken action and garnered support 
from two federal MPs and Windsor's city council for its request 'that the CSC/RadioCanada over-the-air signal be maintained through alternative technology. Without making any assumptions, the request nevertheless seems to suggest that CSC/Radio-Canada failed to work with the communities to thoroughly examine ways in which the broadcaster might offset the loss of the signal, despite the fact that Part VII of the Official Languages Act warrants such a reflection.

Similarly, the City of Windsor's intervention cited a Windsor City Council resolution that noted the shutdown of CBEFT would "force the Francophone community to pay high fees for a cable service" and that "the French language service of the CBC could easily use a method known as 'multiplexing' which would combine multiple digital streams into one signal over a shared medium...(and that) the English transmitter at CBET could be used for this purpose" (City of Windsor, 2012, May 25). A joint intervention by Windsor area MPs Joe Comartin and Brian Masse made in favour of CBEFT similarly suggested that CBC/Radio-Canada use multiplexing to make CBEFT's programming available. In addition, Comartin and Masse noted "(w)e do not believe that the cost of transferring transmitters or the level of viewership should trump the statutory rights of minority language rights in the Canadian broadcasting market" and that "the rate of linguistic transfer from French to English, or in other words, the assimilation rate, (in Windsor) is one of the highest in the country at 73.1\%" (Masse \& Comartin, 2010, June 7). As noted by Anne MacLennan and Irena Knezevic (2012) in reference to the broadcast operations of CBC Radio's Windsor station CBEF that applies equally to the operations of CBEFT-TV, French language broadcasting by the public broadcaster in Windsor "must be considered in the context of the Official Languages policy in Canada and the protection of public and cultural services in both official languages" (p. 13).

Despite the interventions filed, CBEFT was among the hundreds of other analogue CBC/Radio-Canada retransmitters that were shut down in 2012. Broadcasting Decision CRTC 
2012-384 made the following specific reference to the availability of Télévision de Radio-

Canada programming in Windsor, and other cities, in terms of its impact on Canada's official

language minority communities (OLMCs),

12. The Commission has also considered the impact of this change on OLMCs. Although numerous parties, such as the Fédération des communautés francophones et acadienne and the City of Windsor, accepted the CBC's reasons for shutting down its analog transmitters, they noted that the shutdown will eliminate OLMC television service to those households that currently access such programming via the CBC's over-the-air signals. Other interveners, such as the English Language Arts Network and the Commissioner of Official Languages, also expressed concern that in preparing for the shutdown, the CBC did not adequately communicate the shutdown's impact to OLMCs, nor did the CBC adequately explore alternative solutions for maintaining service to OLMCs.

13. The Commission takes note of the above-mentioned concerns and will discuss the delivery of the CBC's services to OLMCs at its upcoming licence renewal.

(CRTC, 2012c)

Similar to the discussions that were planned at the CRTC with regards to the availability of $\mathrm{CBC}$ /Radio-Canada television programming over-the-air in Saint John, NB, discussion of the role of such over-the-air access to $\mathrm{CBC} /$ Radio-Canada television in Windsor, $\mathrm{ON}$ also never happened at CBC/Radio-Canada's long overdue licence renewal hearing at the end of 2012 since by that time public broadcaster had already shut down all of its analogue OTA television transmitters/retransmitters.

\section{Forced household migration to paid and/or usage based access to CBC/Radio-Canada television}

As the analogue OTA CBC/Radio-Canada television-viewing households interviewed for this dissertation have advised, apart from the six households that managed to regain digital OTA television access to $\mathrm{CBC} /$ Radio-Canada television, the public broadcaster's response to Canada's 
digital television transition served to prompt the remaining interviewed households, to seek out comparable access to the public broadcaster byway of entering into a paid BDU subscription service (18 households) or to subscribe to Shaw Direct's no-fee LTSS service (21 households), a service that could end after August 31, 2019. As identified by the Public M.A.P.S. model, when a public broadcaster relies on other intermediaries to fulfill its obligation to provide public service media to households in the digital age, the Cost access sieve layer barrier expands as public broadcasters increasingly make the costs related to the delivery of television programming an external cost, thereby passing the cost of such delivery onto households such that (as noted in Chapter 3) the provision of access to programming is "not borne by the producer but borne by other people" (Parkin \& Bade, 2006 p. 349). While this shift might present less of an access concern for households where the cost of television delivery is not an issue, for households where cost of television delivery is an issue then access to public television and public service media stands to suffer erosion. As households are increasingly forced to meet the post-analogue costs associated with accessing public service media, one or more of the remaining four Public M.A.P.S. access layers must be navigated.

As noted earlier, the catalyst that propelled CBC/Radio-Canada down this transition path was the government of Canada's interest in clearing the $700 \mathrm{MHz}$ spectrum. While it was CBC/Radio-Canada that ultimately decided to take its custom response to Canada's digital television transition, the lack of any special funding from the government of Canada to assist $\mathrm{CBC} /$ Radio-Canada in making a more extensive digital television transition (as was requested by CBC/Radio-Canada) did not assist matters. In contrast, as noted in Chapter 3, the Australian government covered all of the costs associated for both of its public television broadcasters, $\mathrm{ABC}$ and SBS, to replicate their analogue OTA television delivery services with digital OTA 
television transmitters (Given, 2015), in addition to providing other funding to private broadcasters and to citizens. Canada's focus on the anticipated revenues from the $700 \mathrm{MHz}$ auction was the government's priority, a priority that did not serve to enhance citizen access to $\mathrm{CBC} /$ Radio-Canada television-viewing households interviewed for this dissertation.

As $\mathrm{CBC} /$ Radio-Canada continues its journey of reimaging itself as public service media entity, Canadian net neutrality policies and protocols will increase in importance with each step that $\mathrm{CBC} /$ Radio-Canada takes from conventional and $\mathrm{BDU}$ television delivery to its mobile and online delivery strategy (as outlined in its 2014-2015 annual report). The reason for this is due to the fact that $\mathrm{CBC} /$ Radio-Canada does not own or control any mobile or online delivery services. In addition, mobile and online services do not fall under the regulatory purview of the Broadcasting Act. Since CBC/Radio-Canada must rely on other mobile and online intermediaries to faithfully deliver its television programming via such platforms, $\mathrm{CBC} /$ RadioCanada is at the mercy of such providers' abidance of Canada's net neutrality regulations. Otherwise, $\mathrm{CBC} /$ Radio-Canada television access by Canadians via mobile and online services are at risk.

The notion of net neutrality, defined as "[t]he principle that all traffic on the internet be treated equally and without discrimination by network service providers, regardless of its source, ownership, content, or destination" (Shade, 2014, p.448), is embodied in Section 27 of Canada's Telecommunications Act (1993) which deals with "just and reasonable rates", along with the Exemption Order for Digital Media Broadcasting (DMBU). Both regulations were cited in a June 20, 2016 judgement by the Federal Court of Appeal (Federal Court of Appeal, 2016, June 20) related to Bell Mobility's appeal of a CRTC decision which ruled in favour of a 2013 complaint filed by graduate student Benjamin Klass. In its decision, the Commission found that 
Bell had indeed applied "undue and unreasonable preference" when billing customers for its Bell Mobile TV service (CRTC, 2015b).

With respect to the delivery of $\mathrm{CBC}$ programming specifically, the Commission noted in its decision that "Benjamin Klass, makes the argument that, through its inequitable billing practices, Bell is charging unfairly for the consumption of $\mathrm{CBC}$ programming, a free over-the-air service, on mobile networks" (CRTC, 2015b). Furthermore, the CRTC included the following CBC example given by Klass:

37. In regard to Bell Mobility's mobile TV service, Mr. Klass noted that subscribers currently have two options for watching ten hours of Canadian Broadcasting Corporation (CBC) programming on their tablets using a mobile network during a given month: a) using the mobile TV service at Bell Mobility's price of $\$ 5$ (or sometimes for free when the service is offered as a promotion or a bonus), or b) using one of several CBC services accessed over the Internet with their data plan at Bell Mobility's price of $\$ 40$.

(CRTC, 2015b)

The above-noted 2013 example from Klass illustrates that both paths to $\mathrm{CBC}$ were provided by the same company, Bell Mobility, but for different prices. This disadvantaged Bell mobile customers using their data plan to access CBC over the same Bell network. The FCA agreed with Klass. This judgement's insight into the mobile delivery of $\mathrm{CBC} /$ Radio-Canada television by Bell, a for-profit corporation, is just one example of the practices of the nontraditional, brave new world of mobile and online providers. Bell Mobility's undue and unreasonable preference when delivering $\mathrm{CBC}$ /Radio-Canada television was left (publicly) unquestioned by the public broadcaster and was not addressed in terms of citizen access until a Canadian citizen took it upon himself to file a complaint with the CRTC. 


\section{Future research}

In terms of future research, it would be of value to continue to study how Canadians residing in television markets with $\mathrm{CBC} /$ Radio-Canada digital OTA television transmitters have experienced the service with regards to access to CBC/Radio-Canada television programming. Such data would help gauge the value of CBC/Radio-Canada's network of digital television transmitters, if any modifications might be warranted, and also how long the Corporation's OTA transmitters should continue to be supported. Furthermore, since BDUs such as Videotron and Rogers have already started to offer 4K/Ultra TV delivery to their subscribers, it would be prudent for CBC/Radio-Canada to study whether or not a transition to ATSC 3.0 OTA 4K/Ultra TV delivery (as is currently being explored in the United States as part of its $600 \mathrm{MHz}$ auctions that commenced in 2016) will allow the public broadcaster to continue to refine the delivery of its television programming to Canadian television-viewing households and to mobile devices.

As for the future delivery of $\mathrm{CBC} /$ Radio-Canada television programming by way of the Internet, the CRTC's Telecom Notice of Consultation CRTC 2015-134 related to basic telecom services in Canada included a 2016 hearing that focused on the issue of affordable access to broadband Internet in Canada. The decision by the CRTC (CRTC, 2016e) will certainly play a role in future online access to $\mathrm{CBC} /$ Radio-Canada television services, which is why it is rather surprising the $\mathrm{CBC} /$ Radio-Canada neither appeared at the 2016 hearing nor submitted an intervention. One would imagine that since CBC/Radio-Canada noted as part of its justification for the 2012 shutdown of its analogue OTA television service that Canadians should be accessing their future television by way of the Internet and wireless mobile connectivity, and the fact that it is now relying on Canadians being able to achieve affordable broadband Internet to access its television programming - specifically in areas beyond the reach of its 27 digital OTA 
television transmitters - that $\mathrm{CBC} /$ Radio-Canada would have intervened as part of the CRTC 2015-134 consultation. 


\section{Chapter 8: Conclusion}

If the $\mathrm{CBC}$ were ever to become a mere producer of programs available for transmission over stations controlled and operated by others, it would lose contact with the needs and tastes of the Canadian people, and its programs would soon lose the character of a vital national service.

(Canada, 1965, p. 80)

The Commission considers that the responsibility to provide the CBC's services rests with the $\mathrm{CBC}$, not with private broadcasters.

(CRTC, 2016d, p.2)

This chapter provides a summary of the key findings and research contribution, and offers a number of concluding recommendations aimed at improving access to CBC/RadioCanada television programming. As argued in this dissertation, Canada's 2011 digital television transition, and CBC/Radio-Canada's 2012 response to it, did not serve to enhance the provision of universal access to $\mathrm{CBC}$ /Radio-Canada television programming in the digital age. Instead, the events of 2011 and 2012 reinforced the stature of BDUs within Canada's regulated television broadcast system, particularly with regards to the delivery of $\mathrm{CBC} /$ Radio-Canada television programming.

This renewed status of BDUs within Canada's television broadcast system has since entered a period of critical review related to the continued value of such a BDU-centric television delivery system in the digital age and is being given meaningful reconsideration by the Canadian government. Furthermore, the role of CBC/Radio-Canada itself as a national public broadcaster that opted to entirely abandon analogue OTA television delivery, in favour of the perceived economic efficiencies provided by digital technology, is similarly being given critical assessment by the current Minister of Canadian Heritage, Mélanie Joly. 
The focus of this dissertation on post-analogue household access to CBC/Radio-Canada television programming is linked to the status of Canadian cultural citizenship in a vertically integrated television delivery landscape and CBC/Radio-Canada's role as a national public broadcast service in the digital age. As noted by Gregory Taylor (2009),

The $\mathrm{CBC}$, and public broadcasting in general, has a unique perspective in the digital television transition. The public broadcaster was one of the few broadcasters commended by Michael McEwen [former CBC/Radio-Canada Vice President and past President of the industry association Canadian Digital Television] for taking a leadership role in the introduction of digital television (McEwen, 2009). Further study into the distinct challenges faced by the $\mathrm{CBC}$ and its particular role in the digital transition may shed light into future directions for the national public broadcaster. (p. 279).

CBC/Radio-Canada's response to Canada's digital television transition provides insight into the public broadcaster's philosophical approach to serving its mandate within a postanalogue environment. By archiving accounts of the public broadcaster's digital television transition, as detailed by members of CBC/Radio-Canada Management and CBC/Radio-Canada OTA television-viewing households, this dissertation synthesizes a firsthand account of CBC/Radio-Canada's historic television transition in the spirit of Bruno Latour's (1996) retrospective study of France's experimental public transit system Aramis, or the love of technology. Aramis was France's multiphase 18 year effort to complete a self-guided computerized public transit system that was eventually abandoned in 1987. As noted by Latour (1996) in the introduction of Aramis,

I have sought to show technicians that they cannot even conceive of a technological object without taking into account the mass of human beings with all their passions and politics and pitiful calculations, and that by becoming good sociologists and good humanists they can become better engineers and better-informed decision makers (p. viii).

Latour's (1996) Aramis served as a reminder to this dissertation that any technological project, whether a public transit system or a public television service, is not restricted solely to 
technology and that technology is never distinct from other actors involved in a project. As Latour (1996) notes, those involved with the Aramis project "abandoned technology while thinking that it was going to be finalized all by itself, that it was autonomous, that they'd see how things worked out afterward, that it had to be protected from its environment" (p. 287). The Public M.A.P.S. model developed by this dissertation illustrates what is needed to rejuvenate the provision of access to public service media in Canada and that post-analogue television delivery challenges have not sorted themselves out on their own.

A focus on CBC/Radio-Canada's operational response to Canada's digital television transition deadline presented an opportunity to collect findings related to the delivery of public television to Canadians in a post-analogue environment. This dissertation recorded household television access to $\mathrm{CBC} /$ Radio-Canada programming leading up to and after its analogue OTA television service shutdown in 2012. Such a detailed, qualitative archive of television access by such households would likely not exist otherwise (publicly, at least) if not for this dissertation.

As quoted at the top of this chapter, the second Fowler Report of 1965 helps to remind Canadians that $\mathrm{CBC} /$ Radio-Canada is more than simply a Canadian content media production company. The ongoing delivery of $\mathrm{CBC} /$ Radio-Canada television programming by $\mathrm{CBC} /$ RadioCanada remains the responsibility of the Crown Corporation (as most recently reiterated by the CRTC in its August 2016 decision pertaining to the CBC Television disaffiliation of private broadcaster CKSA-DT). While the production of Canadian content certainly continues as part of $\mathrm{CBC} /$ Radio-Canada's mandate in the digital age, its provision of access to its radio and television programming remains equally tied to its mandate. While Canada's Broadcasting Act states that "the programming provided by the (Canadian Broadcasting) Corporation should (i) be predominantly and distinctively Canadian", and such programming remains part of the public 
broadcaster's television services, the analogue OTA CBC/Radio-Canada television viewers interviewed for this dissertation provide evidence of the difficulties some Canadians face in accessing this programming when television delivery duties are left to privately-owned intermediaries to figure out.

\section{Summary of key findings}

This dissertation reveals competing themes on the delivery of public television programming and of public television access by Canadian households in the digital age as expressed by interviewed members of $\mathrm{CBC} /$ Radio-Canada Management and $\mathrm{CBC} /$ Radio-Canada OTA television-viewing households. These findings indicate that the medium by which $\mathrm{CBC} /$ Radio-Canada television programming reaches a Canadian television-viewing household remains linked to the quality of a household's access to the public broadcaster, even in a digital delivery environment. This dissertation has also shown that public television programming does not deliver itself. Lastly, this dissertation has shown that further regulatory and policy action regarding the provision of access to public service media in Canada is required.

If OTA CBC/Radio-Canada television-viewing households located outside of the television markets where the public broadcaster opted to continue to broadcast over-the-air in digital after July 31,2012 had not previously considered the provision of television access to their households, the shutdown of the public broadcaster's analogue OTA television service brought the matter of household access to digital communications front and centre. What these digitallydivided CBC/Radio-Canada television-viewing households soon came to appreciate was that if television content is king (Gates, 1996), television delivery is emperor. In other words, as Marshall McLuhan (1964/1994) advised, content is "like the juicy piece of meat carried by the 
burglar to distract the watchdog of the mind" (p. 18), at least until access to the meat is shutdown.

$\mathrm{CBC} /$ Radio-Canada's response to the federally-mandated (and CRTC enforced) deadline to switch from analogue to digital OTA television delivery in specified digital television markets prompted the public broadcaster to take bold action with regards to the operation of its analogue OTA television service. The prospect of having to convert more than 600 analogue OTA television transmitters/retransmitters to digital presented the service as a target for cost-cutting. While certainly long in the tooth and in need of regular maintenance, akin to Canada's still flying Cold War-era Sea King helicopters, the hundreds of publicly-owned analogue transmitters and associated television delivery infrastructure that compromised CBC/Radio-Canada's analogue OTA television service were deemed by the public broadcaster as amounting to an inefficient operational liability that no longer served the public interest. Despite CBC/Radio-Canada's operational response to Canada's digital television transition, this dissertation has shown that public television programming does not deliver itself and that policy related enhancements to the provision of $\mathrm{CBC} /$ Radio-Canada television programming are overdue.

\section{Research contribution}

With CBC/Radio-Canada's analogue OTA television service shuttered, its digital OTA television transition completed, and the households situated beyond the reach of its 27 digital OTA transmitters expected to go without OTA access to the public broadcaster's television programming (other than households located within the signal footprints of CBC/RadioCanada's two remaining privately-owned Télévision de Radio-Canada affiliates in Québec), an important question to ask is: who cares? What was it about this moment in Canadian television broadcast history that made it worthy of academic study? How do this dissertation's research 
findings contribute to the existing body of research related to the aims of Canada's regulated television broadcast system with regards to the provision of household access to public television programming? Do the research findings of this dissertation matter to the general public?

One way to attempt to answer all the above-stated research contribution questions is to return to the following open-ended question that was posed to each of the 99 OTA CBC/RadioCanada television-viewing households interviewed for this dissertation:

How would you respond to someone who might say, "So, you've lost over-the-air access to CBC/Radio-Canada television. What's the big deal? Just get cable, or satellite, or watch on the Internet, or on your cell phone!'?

The posing of this question to former analogue OTA CBC/Radio-Canada television households prompted a flood of experiences shared by viewers and provided specific examples of how $\mathrm{CBC} /$ Radio-Canada television programming made its way (or not) into their homes. These responses assisted in bringing to light barriers to accessing public television programming in the digital age and provided the data which was analyzed by this dissertation and resulted in the articulation of the Public M.A.P.S. model.

When CBC/Radio-Canada next contemplates a partial or complete shutdown of its remaining network of 27 digital OTA television transmitters, the Public M.A.P.S. model that emerged from the analysis of interviews conducted with $\mathrm{CBC} /$ Radio-Canada television-viewing households cut off from the public broadcaster following the analogue OTA television service shutdown in 2012 will serve as a guide to understand, critique, and respond to any further reduction of access to the public braodcaster's television programming. Barriers to household access to $\mathrm{CBC} /$ Radio-Canada television programming as detailed in the Public M.A.P.S. model must be addressed prior to the shutdown of any additional OTA transmitters by CBC/Radio- 
Canada. Added attention from the public broadcaster regarding barriers to accessing $\mathrm{CBC} /$ RadioCanada television programming provide the promise of maintaining as many pathways as possible by which citizen might gain access to Canada's regulated television system. While it is unfortunate that more steps aimed at enhancing household access to CBC/Radio-Canada television programming did not occur prior to the 2012 shutdown of the public broadcaster's analogue OTA television service, future regulation aimed at avoiding further degrading of access to $\mathrm{CBC} /$ Radio-Canada will be key to the mandate of the Crown Corporation as it moves forward with its shift from public service broadcaster to public service media.

This dissertation informs the ongoing operations of Canada's regulated broadcast and telecommunications systems by highlighting access challenges faced by Canadian households impacted by $\mathrm{CBC}$ /Radio-Canada's retreat from the terrestrial distribution of its television programming by way of publicly-owned infrastructure and publicly-owned spectrum. If Canada does opt to continue to regulate its telecommunications and broadcast systems in the digital age, an age apparently drowning in ubiquitously-available, high quality television programming that has left Canadians awash in a cornucopia of television viewing options (necessitating the CRTC's 2016 Discoverability Summit), what end(s) are Canada's regulated telecommunications and broadcast systems serving?

\section{CBC/Radio-Canada's Digital Television Transmitters: Burden or Asset?}

Following CBC/Radio-Canada's licence renewal hearing in November 2012 and the CRTC's decision in May 2013 to renew the radio and television services of the Corporation until August 31,2018, the Commission recapped the shutdown of the public broadcaster's analogue OTA television service as follows, 
The CBC ceased to operate 440 analog television transmitters in the summer of 2012 when the transition to digital television occurred. The $\mathrm{CBC}$ stated that by shutting down these transmitters it would be able to redirect funds to programming. The CBC further stated that it does not intend to increase digital television over-the-air (OTA) coverage by implementing new digital television transmitters due to its limited financial resources.

Certain individuals, as well the Public Interest Advocacy Centre and OpenMedia.ca (PIAC/OpenMedia), CACTUS and SOS CBEF, stated that the CBC should implement new digital transmitters to increase digital (and high definition) OTA television coverage. The SCFA, however, saw no need for additional digital transmitters provided that the CBC explored other options such as multiplexing to provide service to OLMCs.

Section 3(1)(m)(vii) of the Act states that the programming provided by the CBC should be made available throughout Canada by the most appropriate and efficient means as resources become available for the purpose. Given that the CBC's resources are limited and declining, the Commission is of the view that it would not be appropriate to impose requirements on the $\mathrm{CBC}$ for the establishment of digital television transmitters or the operation of analog television transmitters. In this regard, the Commission notes that Canadians affected by the shutdown of the CBC's transmitters, including those living in OLMCs, are potentially eligible for Shaw Direct's Local Television Satellite Solution assistance program, for which the Commission recently extended the sign-up period until 30 November 2013. The Commission reiterates its statement set out in Broadcasting Regulatory Policy 2010-167 that broadcasters should continue to explore opportunities such as multiplexing to ensure that Canadians have access to free OTA television.

(CRTC, 2013)

As detailed above, the Commission appeared to share at the time CBC/Radio-Canada's own notion of television delivery appropriateness and efficiency when it stated in its licence renewal decision that "it would not be appropriate to impose requirements on the CBC for the establishment of digital television transmitters or the operation of analog television transmitters" since "CBC's resources are limited and declining" (CRTC, 2013). This decision by the Commission in 2013 served to help reinforce CBC/Radio-Canada's main claim that OTA television was no longer an appropriate and efficient mode of television delivery, a decision that now stands in stark contrast to the OTA television delivery decision that the Commission would make less than two years later in the form of its Let's Talk TV OTA television decision. 
This dissertation is a post-analogue call to $\mathrm{CBC} /$ Radio-Canada to renew its direct involvement in the provision of household access to its television programming in the digital age. As the Public M.A.P.S. model developed by this dissertation has detailed, barriers to household access to $\mathrm{CBC} /$ Radio-Canada television programming emerge when the public broadcaster places the burden of providing household access to its programming solely on ambivalent intermediaries.

\section{Concluding recommendations}

This section contributes recommendations related to how CBC/Radio-Canada might enhance the provision of household access to its television programming by Canadian households in the digital age. These recommendations all share an interest in the access component of CBC/Radio-Canada's mandated public television services. This dissertation has detailed how the provision of access to the public broadcaster's television services has been lacking following the shutdown of its analogue OTA television service. The following recommendations collectively argue that the provision of access to $\mathrm{CBC} /$ Radio-Canada television programming by $\mathrm{CBC} /$ Radio-Canada in the digital age involves more than simply pointing households to a BDU provider and/or offering them a mobile device app. The recommendations in this section start with measures that may be immediately implemented by the public broadcaster, followed by steps that will likely require additional planning, negotiation, expenditure, and regulatory approval. The following recommendations address reducing barriers to access to public service media outlined in this dissertation and stem from this dissertation's analysis rather than explicit requests from interviewees. They highlight opportunities to enhance 
access to $\mathrm{CBC}$ /Radio-Canada television programming in the digital age and are informed by the Public M.A.P.S. model.

\section{1) Unencrypt $\mathrm{CBC} /$ Radio-Canada satellite television downlinks}

A recommendation that $\mathrm{CBC} /$ Radio-Canada could implement immediately to improve household access to its television programming would be to unencrypt the CBC Television and Télévision de Radio-Canada station downlink feeds available from the transponders that the public broadcaster is leasing on Telesat's Anik F1R satellite.

As of September 2016, CBC/Radio-Canada OTA television satellite downlink feeds are only available to BDUs capable of unencrypting the feeds and distributing them to cable, satellite, and/or IPTV subscribers. If CBC/Radio-Canada were to unencrypt its downlink feeds, Canadian households with C-band or Ku-band satellite dishes, along with a free-to-air (FTA) satellite receiver, could receive $\mathrm{CBC}$ /Radio-Canada television feeds directly from the Anik F1R satellite. However, unencrypting CBC/Radio-Canada downlinks from Anik F1R would also make the public broadcaster's television signals available to any household with an FTA compatible dish and receiver located across much of North America. While the Minister of Canadian Heritage, Mélanie Joly, is seeking to improve the export of Canadian content to markets outside of Canada as part of her department's consultations on Canadian Content in the Digital World, it's unlikely that such availability of CBC/Radio-Canada television programming outside of Canada fits with the consultation's vision for the export of Canadian content that is focused on "capturing a greater slice of the global pie" of the international television licensing industry in order to financially "support Canadian creators back home” (Canada, 2016, September, p. 10). 
Since the exploitation of television programming rights around the world is based on the licensing of television programming within specific territorial television markets, $\mathrm{CBC} /$ RadioCanada will need to renegotiate its current licensing deals for programming that it does not own, such as Murdoch Mysteries (owned by Shaftsbury Films Incorporated) or the Rick Mercer Report (owned by Island Edge Inc.) if it does not already have the rights to make such television programming available outside of Canada in English and/or French via FTA satellite.

$\mathrm{CBC} /$ Radio-Canada will also need to secure such North American FTA satellite television rights as part of any future television licensing deals. If $\mathrm{CBC} /$ Radio-Canada is unable to secure such rights, due to the cost of such licensing or a conflict with existing licensing deals in the United States, Mexico, or elsewhere in North America, CBC/Radio-Canada will need to seek alternative television programming to fill its schedule. One possible solution to the matter of restrictive territorial licensing of television programming due to copyright is Benedetta Brevini's (2013) recommendation (detailed in Chapter 3 of this dissertation) that PSBs shift to making available programming that is based on Creative Commons licensing. In instances where $\mathrm{CBC} /$ RadioCanada can only afford to licence a certain number of television programs for the distribution within the North American FTA satellite market, the public broadcaster could take Brevini's advice and fill any holes in its television programming schedule with programs that have Creative Commons licences that are not restricted to specific television markets in addition to television programs that are in the public domain.

The unencrypting of CBC/Radio-Canada television feed satellite downlinks would also remedy the problems that the public broadcaster has had with Canadian DTH satellite television providers and their distribution of feeds from the public broadcaster's television stations across the country. As detailed in Chapter 2 of this dissertation, DTH satellite providers are not 
required by the Broadcasting Distribution Regulations to make available all of CBC/RadioCanada's television stations and as such, households are unable to receive satellite access to certain $\mathrm{CBC}$ /Radio-Canada television feeds by way of a DTH satellite television subscription.

Furthermore, unencrypting CBC/Radio-Canada's television feed satellite downlinks would also assist the more than 35,000 Canadian households that switched to Shaw's oversubscribed no-fee Local Television Satellite Solution (LTSS) DTH satellite service that are now unable to receive access to the same $\mathrm{CBC} /$ Radio-Canada television station that the households watched via the public broadcaster's former analogue OTA television service. LTSS households would still need to purchase a separate FTA compatible receiver and FTA satellite dish in order to receive the unencrypted downlink satellite feeds, but such an investment by a household would provide it with access to the $\mathrm{CBC} /$ Radio-Canada television stations preferred by the household.

Although the CRTC will ultimately decide the fate of the LTSS program at Shaw's next DTH licence renewal request hearing, Shaw has already made it clear that it only plans to offer the LTSS program until the end of its current DTH licence term on August 31, 2019, as required by Broadcasting Decision CRTC 2010-782. As such, Shaw is more than likely to request to end its no-fee LTSS program at its next hearing. If the CRTC does not require Shaw, or some other entity, to continue offering the LTSS service to Canadian households and the program ends, LTSS households that lost access to OTA television signals between 2011 and 2012 due to Canada's digital television transition will no longer have no-fee access to $\mathrm{CBC} /$ Radio-Canada television programming via satellite either. Such restrictions, along with Shaw Direct's policy that LTSS subscribers are unable to continue to receive LTSS service if they ever move, make it clear that the LTSS (as currently designed) is not a permanent, comparable, replacement for 
$\mathrm{CBC}$ /Radio-Canada television delivery to Canadian households. At best, the LTSS, as it currently stands, represents a 99 month (May 31, 2011 to August 31, 2019) stop-gap measure to assist Canadian OTA television-households, particularly analogue OTA CBC/Radio-Canada television-viewing households, in adjusting from a regulated Canadian television broadcasting system that previously offered no fee OTA television access to citizens, to a regulated television delivery system based on television access via mandatory paid BDU television subscriptions.

If the CRTC does not require Shaw Direct to continue offering its LTSS service to Canadian households at its next DTH licence renewal, the unencrypted availability of CBC/Radio-Canada television stations by way of FTA satellite will be even more important in terms of the provision of access to $\mathrm{CBC}$ /Radio-Canada television programming to former-LTSS households unable to access CBC/Radio-Canada television by other means. Shaw and CBC/Radio-Canada could coordinate their activities such that each LTSS subscriber would be made aware of the public broadcaster's FTA satellite service prior to the shutdown of the LTSS in 2019 or whatever future dates the CRTC specifies.

\section{2) Enhance access to public service media}

\section{Streaming Video on Demand (SVOD)}

Many of the analogue OTA CBC/Radio-Canada television-viewing households interviewed for this dissertation mentioned attempting to access archived Télévision de RadioCanada and CBC Television programming on demand via the public broadcaster's websites. Functionality barriers related to online buffering were reported by some households, prompting them to give up on streaming the public broadcaster's television programming online. Since such buffering issues are most likely caused by the quality of a household's broadband Internet 
connection, providing users the ability to reduce the video stream quality would help improve access. For example, the lowest quality stream access available from Télévision de RadioCanada's SVOD platform tou.tv was 270p and the lowest quality stream available from CBC Television's SVOD platform watch.cbc.ca was $234 p$ as of September 2016. By providing Canadian households with the option of even lower quality of SVOD streams from CBC/RadioCanada websites, as low as $144 \mathrm{p}$ (as users of YouTube are currently able to do), the public broadcaster can assist Canadian users to both save bandwidth in efforts to avoid monthly data cap overages (another issue in need of remedy) and may also make the difference between someone with a slow Internet connection being able to access CBC/Radio-Canada television programming online or not. It is also important that any commercial spots that stream before $\mathrm{CBC} /$ Radio-Canada SVOD content can also be streamed at a video resolution as low as 144p. Currently, users of $\mathrm{CBC} /$ Radio-Canada SVOD platforms are unable to adjust the stream quality at all for ads that stream before programming. If a household with a slow Internet connection is unable to stream ads that play before $\mathrm{CBC} /$ Radio-Canada SVOD programming then they will never get to the public service media content that they were striving to experience in the first place.

Beyond functional barriers to SVOD access linked to the quality of video streams, many $\mathrm{CBC} /$ Radio-Canada households interviewed for this dissertation also reported a lack of selection of SVOD content available for CBC Television programming specifically. With the beta launch of watch.cbc.ca in 2016, CBC Television has since improved the selection of its programming availability for on demand viewing. Moving forward, both Television de Radio-Canada and CBC Television should ensure that any content that it airs OTA is accessible, without a pay-wall, on its SVOD sites. 
Lastly, in terms of SVOD, CBC/Radio-Canada must ensure that all of its SVOD platforms offer Closed Captioning and Described Video. While CBC Television's newly launched watch.cbc.ca platform does offer both Closed Captioning and Described Video functionality, Télévision de Radio-Canada’s Tou.tv only provides Closed Captioning.

\section{Live Streaming}

Télévision de Radio-Canada already has in place a strong live streaming model for the delivery of its public television programming to Canadian households, one that (like its SVOD service) is freed from any reliance on BDUs to make its programming available to Canadian households. As noted in Chapter 2 of this dissertation, Télévision de Radio-Canada has been live streaming roughly $90 \%$ of its entire television broadcast day since February 2011. By visiting radio-canada.ca and selecting "regardez en direct" on its télé page, households with Internet access can live stream Télévision de Radio-Canada's broadcasts at video resolutions ranging from $480 \mathrm{p}$ to $270 \mathrm{p}$ as of September 2016 . The only programs that are not simultaneously live streamed by Télévision de Radio-Canada are a limited number of programs (mainly foreign) for which it does not have online streaming rights. One downside however to the live streaming of Télévision de Radio-Canada online at radio-canada.ca, compared to via OTA or by way of a BDU, is that neither Closed Captioning nor Described Video of programming was available on the platform as of September 2016.

In contrast to this dissertation's findings related to the household online viewing of Télévision de Radio-Canada programming, while many CBC/Radio-Canada television-viewing households did mention attempting to live stream $\mathrm{CBC}$ Television programming online, a number of households noted that The National was the only CBC Television program that they live streamed on a regular basis (as detailed in Chapter 5 of this dissertation). As of September 
2016, CBC Television live streaming selections at cbc.ca/player and watch.cbc.ca remained restricted to The National, regional supper-hour newscasts, video feeds of regional radio morning shows, limited-time special event television programming such as the Olympics, and select limited-time television news items. As such, this dissertation recommends that $\mathrm{CBC}$ Television match the same level of live streaming of its broadcast day that has been offered by Télévision de Radio-Canada since 2011. David Taras (2015) addresses the concern of "whether by offering high-quality online broadcasting, conventional broadcasters are helping to destroy the very model on which their existence is based" (p. 213), referring to the scarcity model of television program availability used to create value for potential conventional television commercial advertisers, by noting that, "[t]here is even some evidence to suggest that viewing programs online may supplement rather than replace conventional and cable viewing. For instance, NBC did extensive research about viewing habits during the 2012 London Olympics and found that live streaming had little effect on prime-time ratings" (p. 211).

While CBC Television's new video platform watch.cbc.ca would be an ideal platform for it to live stream its broadcast day at a level comparable to Télévision de Radio-Canada, as of September 2016 a beta launch of the new site noted that the platform "will not have live streaming on watch.cbc.ca at launch, but this is something we are continuing to explore" (CBC/Radio-Canada, 2016b).

As was similarly recommend for its SVOD platforms, both Télévision de Radio-Canada and $\mathrm{CBC}$ Television need to enhance the stream quality settings for its live streams as well. Currently, Télévision de Radio-Canada live stream at radio-canada.ca offers a video quality range of $480 \mathrm{p}$ to $270 \mathrm{p}$ and $\mathrm{CBC}$ Television live streams at cbc.ca/player and watch.cbc.ca offer a 
sliding low-medium-high "HD" video quality button. Live streams from all CBC/Radio-Canada online platforms also need to be offered at earlier-mentioning $144 \mathrm{p}$ low quality stream.

Live stream video quality was also limited on CBC/Radio-Canada's official Rio 2016 Olympics websites. CBC/Radio-Canada's official streaming platforms for the games did not offer manual stream quality settings. Instead, an "auto HD" stream quality setting was the only option, meaning that both platforms would always attempt to maximize the stream quality offered to each user. While this might sound appealing in terms of offering users the best quality feed possible, not allowing users to manually adjust the stream quality from the official $\mathrm{CBC} /$ Radio-Canada Olympics web sites and mobile apps could prevent users with low Internet speeds and/or low data caps from live streaming the Olympics. While Télévision de RadioCanada's live stream of its television broadcasts of the 2016 Olympics at radio-canada.ca did allow users the ability to adjust manual stream quality settings, cbc.ca/player did not. As for the 2016 Paralympics, CBC/Radio-Canada fared better with both Télévision de Radio-Canada and $\mathrm{CBC} /$ Radio-Canada offering manually adjustable live streams. $\mathrm{CBC} /$ Radio-Canada has an opportunity to improve live stream access for its coverage of the 2018 PyeongChang Winter Olympics and Paralympics by providing manual stream quality settings (along with Closed Captioning and Described Video).

As noted in Chapter 2, CBC/Radio-Canada has everything to gain from digital disintermediation and should not hold off on offering SVOD and live streaming access to its programming. Such a move would help connect the public broadcaster to non-BDU Canadian television-viewing households of both official languages that have a level of Internet access capable of SVOD and live streaming, in addition to viewers attempting to access the public 
broadcaster's television services in French or English outside of the home via mobile devices, public Wi-Fi, places of work, schooling, and/or public libraries.

As a side note, while the live streaming of Télévision de Radio-Canada's OTA television broadcasts include the same Télévision de Radio-Canada promos and commercials that are broadcast over-the-air, live streams of $\mathrm{CBC}$ Television programs do not. Instead, the few $\mathrm{CBC}$ Television programs that are live streamed display a CBC/Radio-Canada logo and a "Program will Resume Soon" message while CBC Television promos and commercial breaks are airing OTA (although curiously, Closed Captioning of the promos and commercial are still displayed online even though the video and audio is not). If the reason for this discrepancy is due to CBC Television holding out for additional revenue from advertisers in order to have their television commercials available nationally online, $\mathrm{CBC}$ /Radio-Canada should end this practice.

Although this dissertation does recommend that $\mathrm{CBC}$ /Radio-Canada enhance live streaming and SVOD access to its television programming instead of a focus on digital television distribution by way of BDUs, a significant barrier to the accessing of its television programming by way of Canadian ISPs and mobile wireless providers also exists in the country. Canadian telecom providers are regulated under the Telecommunications Act (1993) and not by the Broadcasting Act. While the Telecommunications Act arguably has even stronger regulations pertaining to the universality of access than the Broadcasting Act, the Telecommunications Act does not include any regulations pertaining to the production of, or access to, Canadian television programming specifically. The Telecommunications Act does not explicitly mention CBC/RadioCanada programming or any other radio and television services. Instead, the Telecommunications Act deals broadly with "intelligence" (1993, p.2) rather than radio and television programming. Canada has a long history of telecom regulation related to not 
interfering with communication. This Canadian telecom policy originates from a "commoncarrier principle" that calls for "the separation of carrier and content supply functions, unlike the electronic mass media" (Winseck, 1998, p. 4). As noted by Dwayne Winseck (1998), the "aim of common carriage is to sever mediated communication from the potentially distorting influence of ownership and control, a point unique to telecoms" (p. 3). Thus, live streaming of $\mathrm{CBC} /$ Radio-Canada television programming is not a perfect solution for non-BDU television viewers in Canada since it still requires television viewers to access the public broadcaster via an ISP or a mobile wireless telecom operator that has no requirement to provide special access to $\mathrm{CBC} /$ Radio-Canada television programming under the Telecommunications Act, leaving such users susceptible to possible data cap overage charges and other barriers to access. That being said, based on how many of the previously analogue $\mathrm{CBC} /$ Radio-Canada OTA television viewing research participants interviewed for this dissertation already had Internet access (of varying degrees of download speed), an increase in the live streaming of $\mathrm{CBC} /$ Radio-Canada television programming might not only help to provide a new access point to Canadian households but also to provide an opportunity for Canada's cord cutters/shaver/nevers and others to also gain enhanced access to $\mathrm{CBC} /$ Radio-Canada television. However, in order for $\mathrm{CBC} /$ Radio-Canada to ensure access to its television programming via broadband Internet or mobile wireless connection, improvements to access to Internet services in Canada is needed to remedy the barriers to access detailed in Chapter 6, particularly since CBC/Radio-Canada does not own or control any telecom providers.

Lastly, in terms of the dissertation's recommendations regarding television live streaming and SVOD, it is important that the live streaming of CBC/Radio-Canada's television programming be made available for viewing on the World Wide Web and not strictly on walled 
garden mobile device apps. CBC/Radio-Canada has moved heavily into the mobile device app system, having recently identified mobile delivery as a top priority in its 2014-2015 Annual Report, but television live streaming via CBC/Radio-Canada apps should never occur in lieu of live streaming via $\mathrm{CBC} /$ Radio-Canada web sites. Live streaming of television via the web, whether it be via a laptop, tablet, smartTV, smartwatch, or VR device, provides the most accessible and user-friendly online live streaming of $\mathrm{CBC} /$ Radio-Canada television programming. Live streaming by way of mobile apps is comparatively restrictive, depending on the mobile device being used, the mobile device's particular operating system, which mobile operating systems/devices CBC/Radio-Canada creates apps for, and period of time for which $\mathrm{CBC} /$ Radio-Canada apps continue to be supported by the public broadcaster. Live streaming of television via apps suffers from the barriers to access experienced when attempting to enter other wall-garden online app environments, even when such app streaming occurs on a no-fee basis. While CBC/Radio-Canada will more than likely need to secure additional licensing rights in order to offer such live streaming care of the open web to Canadians, such online rights nonetheless need to be secured and used as part of any future television programming deals that $\mathrm{CBC} /$ Radio-Canada makes as part of its television schedule.

\section{User-based digital television programming with agency}

As detailed in Chapters 3 and 7 of this dissertation, the amount of CBC/Radio-Canada television offerings created with a focus on user-based television experiences has been lacking since the shutdown of $\mathrm{CBC} /$ Radio-Canada's analogue OTA television service. In contrast to traditional television programming that is structured around passive audiences whose level of involvement in a program is limited to paying attention to the story, user-based television experiences instead involve active television users that have high levels of agency in terms of 
their interaction with the television program's narrative. Truly interactive television experiences entail more than simply offering passive television audiences opportunity to vote on a poll or to share a link. User-based television programs offer meaningful opportunities for users to experience television programming in a non-linear fashion that is not restricted to only a linear narrative story path.

With regards to the increased number of different television programs that $\mathrm{CBC} /$ RadioCanada has reportedly been able to afford due in part to the shutdown of its analogue OTA television service, this dissertation recommends that the public broadcaster earmark a greater portion of its annual television programming toward the creation of fiction and non-fiction userfocused digital storytelling narratives. Examples of such user-centred media projects are the interactive projects of fellow Crown Corporation the National Film Board of Canada such as Highrise: Out My Window (2010), Bear 71 (2012), Here at Home (2012), and Way to Go (2015).

\section{3) Embrace the CRTC's 2015 OTA Television Broadcasting Revelation}

After Canada's approach to its digital television transition was completed, the digital television transition awards and accolades had been handed out, and the freed-up $700 \mathrm{MHz}$ spectrum had been auctioned off, industry and government support for, and mention of, digital OTA television in Canada was low. By the time the CRTC announced its Let's Talk TV: A Conversation with Canadians phase of the CRTC's Let's Talk TV hearing in April 2014, the Commission seemed to be more than open to the idea of ending over-the-air television delivery in Canada entirely as evident in the following question it posed to Canadians as part of the hearing:

Q24. Is regulatory intervention necessary to maintain access to local television 
stations and, if so, how could this best be achieved? Given that the vast majority of Canadians receive television services through a cable or satellite subscription, are there compelling reasons to maintain and support OTA transmission? Would the discontinuation of OTA transmission allow local television stations to devote more resources to programming? If the Commission determines that OTA transmission should no longer be required, under what timeframe should this be implemented? (CRTC, 2014a)

Between April 2014 and January 2015 however, CRTC Chairman J.P. Blais and the rest of the Commission appeared to have had a regulatory revelation of sorts after hearing from Canadians on the topic of OTA television in Canada and particularly the OTA television delivery of $\mathrm{CBC} /$ Radio-Canada television programming.

In its written submission to to the CRTC's Let's Talk TV hearing, CBC/Radio-Canada's response to the CRTC's question about the continuation of OTA transmission stated that "the current licensing regime for conventional television should be modified to permit conventional television broadcasters to operate without relying on OTA transmission, if they so choose" (CBC/Radio-Canada, 2014b, p 8-9). When CRTC Chairman Blais asked CBC/Radio-Canada at its hearing appearance whether it felt that Canadians were ready for such a "fundamental change", CBC/Radio-Canada's Vice-President, Technology, and Chief Regulatory Officer, Steven Guiton, stated "[w]e actually think they are ready, Mr. Chairman" (CRTC, 2014b). When Blais then asked whether $\mathrm{CBC} /$ Radio-Canada had conducted any surveys that indicated that its viewers "would be willing to accept" the change, Guiton advised that it had not.

Four and half months later, CRTC Chairman Blais announced the CRTC's decision on the future of OTA television in Canada at a January 2015 breakfast meeting in London, Ontario (ironically one of the cities that lost OTA access to CBC/Radio-Canada television in 2012). While flanked on a stage by an OTA television antenna on either side, Blais announced to the London Chamber of Commerce breakfast attendees that the Commission would continue to 
provide regulator support for OTA television transmission in Canada in the form of Broadcasting

Regulatory Decision CRTC 2015-24. As noted by Blais that morning,

It's natural in an era of such fundamental change that old-style technologies get left behind. As we increasingly look to new television delivery models, we must be mindful not to forget about the essential public service provided by over-the-air television, the critical connection it forges with audiences. We should also keep in mind that $97 \%$ of Canadians live within range of a transmitter.

During our consultations, we had proposed that local stations be allowed to shut down their transmitters. Canadians reacted and told us that the time had not yet come. Ninety-five percent of participants told us that access to OTA stations is of great importance. This is not surprising when you consider that over $40 \%$ of viewing between 7 and 11 p.m. in the English-language market and over 50\% in the French-language market is to local television stations. (CRTC, 2015c).

Citing a Numeris report that noted " $8.1 \%$ of Canadians have chosen to access the television system free, over the air", the CRTC's 2015-24 decision details the Let's Talk TV interventions that the Commission received on the topic of OTA television:

8. Over $95 \%$ of the participants who posted comments on the topic of over-the-air television in the online consultation held during Phase 3 referred to the importance and value of the ability to receive television programs inexpensively over the air and opposed proposals to shut down transmitters. Many of the interveners in Phase 3 of the consultation were of the same view. They argued that many Canadians rely on over-the-air transmission to get their local news and programming and that, in some areas, over-the-air reception is the only means available to watch television. Some suggested that if Canadian conventional television stations were to shut down their transmitters, Canadian viewership would shift toward watching American over-the-air signals.

9. Online consultation participants as well as some interveners argued that over-the-air television is an inexpensive alternative to cable and satellite television. As an example, one online participant stated: "I do not subscribe to cable, and I have no plans on ever subscribing, I watch the local [over-the-air] channels and supplement with Netflix and/or streaming off the Internet to watch anything I want to watch." Some argued that fixed- and low-income households would be greatly affected by a shutdown of over-the-air transmitters. Some also suggested that over-the-air television can be used as a public warning system in case of natural disasters and other emergency situations. (CRTC, 2015a) 
Furthermore, as part of the Commission's 2015 OTA television decision, the CRTC also noted the following with respect to OTA television delivery,

The Commission considers that over-the-air television reception plays an important role in the Canadian broadcasting system, at this time, particularly with respect to the local and Canadian programming offered by conventional television stations. The Commission also considers that it is in the public interest that Canadians continue to have access to this inexpensive means of receiving Canadian programming. (CRTC, 2015, Jan 29a?)

As quoted above, the CRTC had determined after hearing from Canadians that Canada's OTA television delivery system (contrary to the CRTC's own hunch prior to Let's Talk TV) was indeed continuing to serve the public interest to the public, particularly with regards to how OTA television delivery provided affordable access to television, particularly local programming. In addition, the CRTC also mentions in decision Broadcasting Regulatory Policy CRTC 2015-24 that OTA broadcasters like Bell and $\mathrm{CBC} /$ Radio-Canada proposed alternative delivery systems in lieu of OTA television broadcasting in their respective Let's Talk TV submissions, proposals that suggested that BDU delivery be the only means of regulated television distribution in the country and that OTA broadcasters (which would no longer actually broadcast) would negotiate fees that they would receive from each BDU in return for the right to distribute the broadcaster's programming (paragraph 17). The CRTC's response to the Bell and CBC/Radio-Canada proposals noted that such a move,

would result in increased costs to BDU subscribers and would reduce the viability of a low-cost entry point for consumers who choose to subscribe to a BDU. With respect to the $\mathrm{CBC}$, the Broadcasting Act (the Act) states that the programming provided by the $\mathrm{CBC}$ should be made available throughout Canada by the most appropriate and efficient means and as resources become available for the purpose. The Commission considers that overthe-air transmission remains an appropriate and efficient way for the $\mathrm{CBC}$ to provide programming to Canadians. With respect to Bell, the Commission notes that when Bell acquired stations from Astral Media inc., it committed to keep open until 2017 all of its conventional television stations. (2015, January 29a). 
The findings of the CRTC's 2013-2015 Let's Talk TV initiative seemingly persuaded the Commission to require the continued operation of over-the-air transmitters by Canada's licensed television broadcasters, resoundingly confirming the ongoing role that both OTA broadcasting and a distinct Broadcasting Act play in the digital television era. While the CRTC of Blais' predecessor Konrad von Finckenstein advocated in the late 2000s that the Broadcasting Act and the Telecommunications Act (along with the Radio-communications Act) be combined on the grounds that "efficiency requires that the Commission be given the flexibility to respond to a changing broadcasting environment" (Armstrong, 2010, p. 240), Robert Armstrong (2010) cautions against combining the acts due to "a potential danger that certain economic objectives of the Telecommunications Act, such as enhancing efficiency and competitiveness or fostering an increased reliance on market forces, would be transferred inappropriately to broadcasting” (p. 241).

If, as per the CRTC's post-January 31, 2015 revelation, that OTA television delivery continues to serve the public interest, it's unclear why Canada has not been more proactive in testing and approving its own a 4K OTA television standard (such as the ATSC 3.0 standard that the United States is currently considering) and mandating that a 4K OTA tuner be installed in any $4 \mathrm{~K}$ television set sold in the country. While the Commission has asked Canada's verticallyintegrated BDUs to advise on their future plans (if any) for broadcasting via the ATSC 3.0 digital OTA television standard that allows for OTA 4K television delivery, as part of their 2017 television licence renewal requests (CRTC, 2016a), a clear policy directive on ATSC 3.0 (in cooperation with ISED) is required of the regulator.

As detailed throughout this dissertation, concerns of regulatory efficiency-creep described by Armstrong (2010) are largely already apparent in the Broadcasting Act of 1991 and 
the post-analogue television delivery operations of $\mathrm{CBC} /$ Radio-Canada. With the possibility of a new, or merged, Broadcasting Act on the horizon, care of Minister of Canadian Heritage Mélanie Joly's review of "the government's current cultural policy toolkit" (Canada, 2016, June 28), the combined forces of the cult of efficiency (Stein, 2001) and the lure of the digital sublime (Mosco, 2004/2005) may further degrade citizen access to CBC/Radio-Canada television delivery services depending on the final recommendations made by Joly, a self-described "Heritage Minister who thinks about digital technology first and foremost" (Leblanc, 2016, April 25).

In the meantime, it would be prudent for $\mathrm{CBC} /$ Radio-Canada to give its dark horse network of 27 digital OTA television transmitters renewed support and promotion. At a minimum, the 14 CBC Television and 13 Télévision de Radio-Canada television transmitters should continue to remain operational beyond the anticipated future $600 \mathrm{MHz}$ spectrum repack in Canada. Some of CBC/Radio-Canada's digital OTA transmitters are only four years old and the average lifespan of a solid-state digital OTA television transmitter is "easily 15 years at the absolute minimum" according to estimates (Kovacs, 2015, July 24). With regular maintenance and repairs there is no reason why $\mathrm{CBC} /$ Radio-Canada's OTA digital television transmitters won't match the longevity of a Sea King helicopter.

$\mathrm{CBC} /$ Radio-Canada should also immediately request permission from the CRTC to commence the multiplexing of its digital OTA television transmitters. While $\mathrm{CBC} /$ Radio-Canada has historically resisted the use of multiplexing over concerns related to sacrificing HD signal quality, these concerns are not warranted. As noted earlier in this dissertation, a single ATSC transmitter can broadcast one HD quality feed along with other feeds within a $6 \mathrm{MHz}$ of channel of spectrum operating at the maximum capacity of $19.39 \mathrm{Mbps}$. In terms of how to prioritize the 
multiplexing of $\mathrm{CBC} /$ Radio-Canada's digital OTA television transmitters in order to enhance access to its television programming across the country, $\mathrm{CBC} /$ Radio-Canada should first request permission to use multiplexing to offer both CBC Television and Télévision de Radio-Canada feeds in the 13 television markets where it currently only has one digital OTA television transmitter operating. For example, Calgary currently has a CBC Television digital OTA transmitter but no Télévision de Radio-Canada digital OTA transmitter. If CBC/Radio-Canada were to multiplex its Calgary CBC Television transmitter it could add Télévision de RadioCanada's Alberta feed as a subchannel via the same single digital OTA transmitter within the 6 $\mathrm{MHz}$ of spectrum currently used to only send $\mathrm{CBC}$ Television programming to Calgarians. Similarly, CBC/Radio-Canada could use multiplexing to offer a subchannel of CBC Television's Fredericton feed via its Télévision de Radio-Canada digital OTA transmitter in Moncton that currently only offers Télévision de Radio-Canada television to area residents. The aim of these measures would be to remedy some of the access issues identified by the OTA CBC/RadioCanada television viewing households featured in Chapter 5.

Once CBC/Radio-Canada's single digital OTA television transmitter markets have commenced multiplexing, the public broadcaster should next request permission from the CRTC to try multiplexing its remaining 14 digital OTA television transmitters located in markets that have both a CBC Television digital OTA transmitter and a Télévision de Radio-Canada digital OTA television transmitter. Multiplexing in such markets would allow CBC/Radio-Canada to actually enhance post-analogue household access to television programming in languages other than English and French (such as Indigenous language programming) and to radio programming.

Lastly, CBC/Radio-Canada needs to establish agreements with provincial educational television broadcasters such as TVO and Télé-Québec, in addition to Canadian private television 
broadcasters such as CTV, Global Television, City, and TVA, to use multiplexing technology to broadcast $\mathrm{CBC}$ and/or Radio-Canada television from non-CBC/Radio-Canada transmitters located in television markets where $\mathrm{CBC} /$ Radio-Canada no longer has an OTA television presence. While provincial educational broadcasters and private broadcasters would likely expect $\mathrm{CBC} /$ Radio-Canada to pay a monthly fee for such use of spectrum, these feeds would likely still cost the Corporation less than $\mathrm{CBC} /$ Radio-Canada having to set up and maintain its own transmitters and towers in such markets.

On the topic of the popularity of digital OTA television multiplexing by OTA television broadcasters in the United States, if no Canadian OTA television broadcasters will agree to multiplex CBC/Radio-Canada's television services on their transmitters located within Canada, as a last resort perhaps digital OTA television broadcasters in the United States with transmitters positioned near the Canada/US border might be willing to accept funds or other services from $\mathrm{CBC} /$ Radio-Canada so as to improve access to the television programming of Canada's national public television broadcaster by Canadian citizens. While this would certainly be unusual and would require FCC approval, it would nonetheless help to improve household access to CBC/Radio-Canada.

If Canadian provincial OTA television broadcasters, Canadian private OTA television broadcasters, and American OTA television broadcasters all refuse to multiplex CBC/RadioCanada television stations via their own digital OTA television transmitters, $\mathrm{CBC} /$ Radio-Canada could alternatively request that such broadcasters be forced to allow CBC/Radio-Canada to install its own digital OTA television transmitters on their towers. Such tower-sharing is something that the CRTC has been advocating (mainly with respect to cell phone towers) and this would like be regarded positively with regards to OTA television delivery as well. 
Furthermore, each of CBC/Radio-Canada's 27 digital OTA television transmitters should be calibrated such that the Effective Radiated Power (ERP) is set at the highest allowed by ISED and the CRTC so as to maximize the number of Canadians who might benefit from its OTA signals, as CBC/Radio-Canada has done previously in Ottawa (CBC/Radio-Canada, 2012d), Winnipeg (CBC/Radio-Canada, 2015b), and elsewhere.

\section{4) Provide Wi-Fi access to Canadians}

CBC/Radio-Canada could explore with ISED and the CRTC whether or not it is able to offer a Wi-Fi service to Canadians. Since $\mathrm{CBC} /$ Radio-Canada has been using spectrum for television broadcasting since 1952, it is likely that it could make a good case that it should leverage existing Wi-Fi spectrum as part of its provision of access mandate to Canadians. Such a $\mathrm{CBC} /$ Radio-Canada Wi-Fi service could be used to make $\mathrm{CBC} /$ Radio-Canada television programming available to Canadians, perhaps along with other public services along the lines of Gregory Taylor and Catherine Middleton's (2011) proposed Canada Broadband Portal (CBP). Such CBC/Radio-Canada Wi-Fi service, delivered by way of portable Wi-Fi transmitters or by Wi-Fi transmitters attached to neighbourhood utility poles, would allow Canadians to engage with $\mathrm{CBC} /$ Radio-Canada in a truly participatory manner (in addition to contributing their own programming in conjunction with the public broadcaster reminiscent of $\mathrm{CBC}$ 's $Z e D$ and $\mathrm{CBC}$ Radio's National Farm Radio Forum).

One example of the need for such a Wi-Fi service from CBC/Radio-Canada was made apparent in June 2016 when it was reported that a Wi-Fi hot spot lending pilot project that allowed eligible Toronto Public Library (TPL) patrons without home Internet to borrow a Wi-Fi box for up to six months suffered from a monthly data cap of 10 GB (Pearson, 2016). In 
response, the Toronto Public Library advised that it was the best deal that it could find and that the wireless Internet provider, Telus, was the only provider that expressed interest in the project TPL was offering in conjunction with Google (Pearson, 2016). Canada needs CBC/RadioCanada to champion such Wi-Fi initiatives in accordance with an interpretation of its mandate that is appropriate for a digital mediascape where the public broadcaster has no analogue OTA television transmitters, few digital OTA television transmitters, and no other way to ensure the provision of household access to its television programming beyond delivery by way of its benevolent BDU frenemies.

\section{Concluding remarks}

This dissertation's Public M.A.P.S. model emerged from CBC/Radio-Canada's 2012 operational reaction to Canada's 2011 digital television transition, via the shared experiences of interviewed members of CBC/Radio-Canada Management involved with the digital television transition and interviews with analogue OTA CBC/Radio-Canada televisionviewing households located beyond the reach of CBC/Radio-Canada's 27 digital OTA transmitters. These perspectives on CBC/Radio-Canada's digital television transition as described by those who were either directly involved with, or directly affected by, the public broadcaster's operational response are now on record and have been added to the historical archive of Canada's overall digital television transition.

Barring a bold shift by $\mathrm{CBC} /$ Radio-Canada, it is unlikely that OTA television viewing households in Canada that did not gain digital OTA television access to Canada's public broadcaster following the shutdown of its analogue OTA television service, ever will. On the contrary, Canadian OTA television viewing households that do have digital OTA television 
access to $\mathrm{CBC} /$ Radio-Canada may see a further erosion of their access to the public broadcaster's television programming, depending on how Canada decides to approach its 600 $\mathrm{MHz}$ spectrum auction, and whether or not the country continues to regard OTA television delivery as the most suitable mode of regulated digital television delivery for 4K/Ultra HD television programming as it did when it was forging regulation related to the delivery of HD television programming.

Regardless of the future of OTA television in Canada, this dissertation's findings, and its Public M.A.P.S. model based on the findings, nonetheless stand to provide evidence of the importance of the provision of public television access in the digital era. Now more than ever (or at least since the 1950s), CBC/Radio-Canada's hands-on direct involvement in the digital delivery of its television programming to Canadian households is called for in an era where BDU television's appeal, and its regulatory support in the name of the public interest, is in question. If $\mathrm{CBC} /$ Radio-Canada is still up for the challenge of attempting to maintain the imagined nation of Canada in the digital age, a renewed focus by $\mathrm{CBC} /$ Radio-Canada on eliminating, or at least minimizing, barriers to household access to its television programming in the digital age, as related to household cost, programming availability, viewing functionality, à la carte service, and locally relevant feed(s), is more than four years overdue. 


\begin{tabular}{|c|c|c|c|c|c|}
\hline $\begin{array}{l}\text { OTA } \\
\text { NUMBER }\end{array}$ & AGE & GENDER & VOCATION & $\begin{array}{l}\text { PROVINCE/ } \\
\text { TERRITORY }\end{array}$ & $\begin{array}{l}\text { REGAINED } \\
\text { ACCESS? }\end{array}$ \\
\hline OTA001 & 30 & MALE & SOFTWARE ENGINEER & $\mathrm{ON}$ & NO \\
\hline OTA002 & 39 & MALE & IT CONSULTANT & ON & NO REPLY \\
\hline OTA003 & 51 & FEMALE & $\begin{array}{l}\text { EDUCATIONAL } \\
\text { CONSULTANT }\end{array}$ & $\mathrm{BC}$ & $\mathrm{NO}$ \\
\hline OTA004 & 55 & FEMALE & PUBLIC HEALTH NURSE & $\mathrm{ON}$ & SHAW DIRECT \\
\hline OTA005 & 49 & MALE & LIBRARY TECHNICIAN & PEI & $\mathrm{NO}$ \\
\hline OTA006 & 58 & MALE & IT CONSULTANT & ON & $\mathrm{NO}$ \\
\hline OTA007 & 67 & MALE & $\begin{array}{l}\text { RETIRED SCHOOL } \\
\text { TEACHER }\end{array}$ & $\mathrm{AB}$ & NO \\
\hline OTA008 & 86 & MALE & RETIRED & NL & NO REPLY \\
\hline OTA009 & 49 & FEMALE & $\begin{array}{l}\text { HUMANITARIAN/ALGON } \\
\text { QUIN PARK WORKER }\end{array}$ & ON & SHAW LTSS \\
\hline OTA010 & 58 & FEMALE & SELF-EMPLOYED & $\mathrm{ON}$ & $\mathrm{NO}$ \\
\hline OTA011 & 65 & MALE & RETIRED IT MANAGER & NS & BELL SAT TV \\
\hline OTA012 & 63 & FEMALE & RETAILER & $\mathrm{BC}$ & SHAW LTSS \\
\hline OTA013 & 64 & FEMALE & $\begin{array}{l}\text { EXECUTIVE DIRECTOR } \\
\text { OF A CHARITY }\end{array}$ & $\mathrm{QC}$ & $\mathrm{NO}$ \\
\hline OTA014 & 66 & FEMALE & SEMI-RETIRED & NL & $\mathrm{NO}$ \\
\hline OTA015 & 56 & MALE & RETIRED & NS & OTA DTV \\
\hline OTA016 & 68 & FEMALE & $\begin{array}{l}\text { RETIRED HIGH SCHOOL } \\
\text { TEACHER }\end{array}$ & ON & SHAW LTSS \\
\hline OTA017 & 77 & MALE & RETIRED SURGEON & QC & BELL SAT TV \\
\hline OTA018 & 53 & MALE & RETIRED & $\mathrm{ON}$ & SHAW LTSS \\
\hline OTA019 & 50 & FEMALE & $\begin{array}{l}\text { SMALL BUSINESS } \\
\text { OWNER }\end{array}$ & ON & BELL SAT TV \\
\hline OTA020 & 65 & MALE & $\begin{array}{l}\text { PROFESSIONAL } \\
\text { ENGINEER }\end{array}$ & MB & NO REPLY \\
\hline OTA021 & 90 & FEMALE & - & MB & NO REPLY \\
\hline OTA022 & 56 & FEMALE & PUBLIC HEALTH FIELD & $\mathrm{AB}$ & TELUS SAT \\
\hline OTA023 & 63 & MALE & SEMI-RETIRED & ON & NO \\
\hline OTA024 & 61 & MALE & SEMI-RETIRED & $\mathrm{ON}$ & NO REPLY \\
\hline OTA025 & 68 & MALE & RETIRED & $\mathrm{ON}$ & $\mathrm{NO}$ \\
\hline OTA026 & 74 & MALE & $\begin{array}{l}\text { RETIRED UNITED } \\
\text { CHURCH MINISTER }\end{array}$ & $\mathrm{AB}$ & TELUS SAT \\
\hline OTA027 & 60 & MALE & RETIRED & $\mathrm{ON}$ & BELL SAT TV \\
\hline OTA028 & 81 & FEMALE & SENIOR & $\mathrm{ON}$ & $\mathrm{NO}$ \\
\hline OTA029 & 78 & MALE & RETIRED & $\mathrm{BC}$ & NO REPLY \\
\hline OTA030 & 64 & FEMALE & $\begin{array}{l}\text { EXECUTIVE DIRECTOR } \\
\text { OF A COMMUNITY } \\
\text { ASSOCIATION }\end{array}$ & $\mathrm{QC}$ & $\mathrm{NO}$ \\
\hline OTA031 & 63 & FEMALE & $\begin{array}{l}\text { PRIVATE MUSIC } \\
\text { TEACHER }\end{array}$ & NS & NO REPLY \\
\hline OTA032 & 46 & FEMALE & $\begin{array}{l}\text { HOMEMAKER/STAY AT } \\
\text { HOME MOM }\end{array}$ & $\mathrm{QC}$ & BELL SAT TV \\
\hline OTA033 & $58 / 54$ & MALE,FEMAL & ARTIST, HIGH SCHOOL TEACHER & $\mathrm{BC}$ & $\mathrm{NO}$ \\
\hline
\end{tabular}




\begin{tabular}{|c|c|c|c|c|c|}
\hline OTA034 & 51 & MALE & $\begin{array}{l}\text { SPECIAL NEEDS } \\
\text { ASSOCIATE }\end{array}$ & NS & SHAW LTSS \\
\hline OTA035 & 40 & FEMALE & PHYSICIAN & $\mathrm{BC}$ & NO REPLY \\
\hline OTA036 & 65 & MALE & RETIRED TEACHER & ON & SHAW LTSS \\
\hline OTA037 & 56 & MALE & $\begin{array}{l}\text { PROVINCIAL } \\
\text { GREENHOUSE } \\
\text { SPECIALIST } \\
\end{array}$ & MB & $\mathrm{NO}$ \\
\hline OTA038 & 49 & FEMALE & SELF-EMPLOYED & $\mathrm{BC}$ & SHAW LTSS \\
\hline OTA039 & 47 & MALE & BOOKSELLER & $\mathrm{ON}$ & OTA DTV \\
\hline OTA040 & $633 / 4$ & FEMALE & RETIRED & MB & NO REPLY \\
\hline OTA041 & 48 & FEMALE & TEACHER & NS & $\mathrm{NO}$ \\
\hline OTA042 & 53 & FEMALE & $\begin{array}{l}\text { LICENSED PRACTICAL } \\
\text { NURSE }\end{array}$ & NL & NO REPLY \\
\hline OTA043 & 42 & MALE & $\begin{array}{l}\text { MUSEUM COLLECTION } \\
\text { TECHNICIAN }\end{array}$ & $\mathrm{AB}$ & NO \\
\hline OTA044 & 41 & FEMALE & COORDINATOR & NS & $\mathrm{NO}$ \\
\hline OTA045 & 52 & MALE & BIOLOGIST & SK & SHAW LTSS \\
\hline OTA046 & 40 & FEMALE & $\begin{array}{l}\text { VISUAL } \\
\text { ARTIST/MANAGER OF A } \\
\text { SHIPPING COMPANY }\end{array}$ & NL & SHAW LTSS \\
\hline OTA047 & - & FEMALE & - & NL & NO REPLY \\
\hline OTA048 & 72 & MALE & $\begin{array}{l}\text { LAB TECHNICIAN AT A } \\
\text { UNIVERSITY }\end{array}$ & $\overline{\mathrm{QC}}$ & $\mathrm{NO}$ \\
\hline OTA049 & 61 & MALE & $\begin{array}{l}\text { BROADCAST } \\
\text { TECHNOLOGIST }\end{array}$ & ON & SHAW LTSS \\
\hline OTA050 & 69 & FEMALE & RETIRED TEACHER & ON & $\begin{array}{l}\text { NORTH } \\
\text { FRONTENAC } \\
\text { TELEPHONE CO. }\end{array}$ \\
\hline OTA051 & 65 & MALE & $\begin{array}{l}\text { RETIRED } \\
\text { MECHANIC/WELDER }\end{array}$ & $\mathrm{BC}$ & SHAW PAID \\
\hline OTA052 & 27 & MALE & HIGH SCHOOL TEACHER & NT & OTA DTV \\
\hline OTA053 & 56 & MALE & $\begin{array}{l}\text { UNEMPLOYED, ON } \\
\text { DISABILITY }\end{array}$ & ON & BELL SAT TV \\
\hline OTA054 & 40 & FEMALE & LIBRARY TECHNICIAN & ON & $\mathrm{NO}$ \\
\hline OTA055 & 58 & FEMALE & POLITICIAN & YK & SHAW LTSS \\
\hline OTA056 & 64 & MALE & RETIRED & $\mathrm{ON}$ & SHAW LTSS \\
\hline OTA057 & 56 & MALE & COMMUNITY WORKER & QC & OTA DTV \\
\hline OTA058 & 50 & MALE & BOAT DESIGNER & NS & NO \\
\hline OTA059 & 51 & MALE & ARTIST & YK & NO \\
\hline OTA060 & 68 & MALE & NOTARY & QC & BELL SAT TV \\
\hline OTA061 & $72 / 68$ & $\begin{array}{l}\text { MALE, } \\
\text { FEMALE }\end{array}$ & $\begin{array}{l}\text { RETIRED,SELF- } \\
\text { EMPLOYED }\end{array}$ & ON & $\begin{array}{l}\text { SHAW DIRECT, } \\
\text { BELL SAT TV }\end{array}$ \\
\hline OTA062 & 57 & FEMALE & SELF-EMPLOYED & MB & $\mathrm{NO}$ \\
\hline OTA063 & - & FEMALE & RETIRED TEACHER & $\mathrm{ON}$ & BELL SAT TV \\
\hline OTA064 & 53 & FEMALE & TEACHER & $\mathrm{NS} / \mathrm{ON}$ & LTSS,BELL FIBE \\
\hline OTA065 & 39 & FEMALE & $\begin{array}{l}\text { INTERNAL RELATIONS } \\
\text { COORDINATOR }\end{array}$ & QC & NO \\
\hline OTA066 & 64 & MALE & GALLERIST/FARMER & NL & NO REPLY \\
\hline OTA067 & 48 & MALE & TRADE UNION COORDINATOR & QC & $\begin{array}{l}\text { DUCLOS \& MICHAUD } \\
\text { TELECOM }\end{array}$ \\
\hline
\end{tabular}




\begin{tabular}{|c|c|c|c|c|c|}
\hline OTA068 & 23 & FEMALE & STUDENT & $\mathrm{QC}$ & OTA DTV \\
\hline OTA069 & 76 & MALE & RETIRED PROFESSOR & NS & NO REPLY \\
\hline OTA070 & 66 & MALE & REGISTERED NURSE & $\mathrm{YK}$ & SHAW LTSS \\
\hline OTA071 & 47 & MALE & ARTIST & $\mathrm{ON}$ & SHAW LTSS \\
\hline OTA072 & 58 & FEMALE & $\begin{array}{l}\text { COMMUNITY } \\
\text { OUTREACH WORKER }\end{array}$ & NS & NO \\
\hline OTA073 & 57 & MALE & FARMER & SK & SHAW DIRECT \\
\hline OTA074 & 40 & FEMALE & ARTIST & $\mathrm{QC}$ & $\mathrm{NO}$ \\
\hline OTA075 & 54 & FEMALE & FARMER & QC & SHAW DIRECT \\
\hline OTA076 & 45 & FEMALE & TRANSLATOR & QC & SHAW LTSS \\
\hline OTA077 & 24 & FEMALE & STUDENT & $\mathrm{ON}$ & $\mathrm{NO}$ \\
\hline OTA078 & 58 & FEMALE & FILMMAKER & $\mathrm{QC}$ & SHAW DIRECT \\
\hline OTA079 & 61 & FEMALE & $\begin{array}{l}\text { RETIRED LABORATORY } \\
\text { TECHNICIAN }\end{array}$ & QC & $\mathrm{NO}$ \\
\hline OTA080 & 40 & FEMALE & LEGAL ASSISTANT & $\mathrm{QC}$ & $\mathrm{NO}$ \\
\hline OTA081 & 59 & MALE & PUBLICIST/JOURNALIST & NB & BELL ALIANT \\
\hline OTA082 & 62 & MALE & $\begin{array}{l}\text { FIRE LOOKOUT } \\
\text { OBSERVER }\end{array}$ & $\mathrm{AB}$ & NO REPLY \\
\hline OTA083 & 58 & MALE & $\begin{array}{l}\text { TRUCK DRIVER, } \\
\text { OWNER/OPERATOR }\end{array}$ & NS & BELL SAT TV \\
\hline OTA084 & 40 & FEMALE & TEACHER & $\mathrm{ON}$ & SHAW LTSS \\
\hline OTA085 & 63 & MALE & $\begin{array}{l}\text { DESKTOP } \\
\text { PUBLISHER/ELECTRICAL } \\
\text { ENGINEER }\end{array}$ & $\mathrm{ON}$ & $\mathrm{NO}$ \\
\hline OTA086 & 67 & MALE & RETIRED & $\mathrm{AB}$ & NO REPLY \\
\hline OTA087 & 57 & MALE & BIOLOGIST & YK & SHAW LTSS \\
\hline OTA088 & 65 & MALE & LANDSCAPER & NS & LTSS/OTA DTV \\
\hline OTA089 & 77 & FEMALE & RETIRED & $\mathrm{ON}$ & CABLE \\
\hline OTA090 & 53 & FEMALE & $\begin{array}{l}\text { SELF-EMPLOYED } \\
\text { LANDSCAPER }\end{array}$ & $\mathrm{ON}$ & NO \\
\hline OTA091 & 76 & FEMALE & $\begin{array}{l}\text { RETIRED REGISTERED } \\
\text { NURSE }\end{array}$ & $\mathrm{ON}$ & NO REPLY \\
\hline OTA092 & 53 & FEMALE & $\begin{array}{l}\text { CUSTOMER } \\
\text { RELATIONSHIP } \\
\text { MANAGEMENT } \\
\end{array}$ & PEI & SHAW DIRECT \\
\hline OTA093 & 55 & MALE & TEACHER & $\mathrm{QC}$ & NO \\
\hline OTA094 & 63 & FEMALE & RETIRED & YK & NO REPLY \\
\hline OTA095 & 76 & FEMALE & RETIRED & SK & SHAW LTSS \\
\hline OTA096 & 68 & FEMALE & RETIRED & $\mathrm{BC}$ & SHAW LTSS \\
\hline OTA097 & 31 & FEMALE & CIVIL SERVANT & QC & $\mathrm{NO}$ \\
\hline OTA098 & 80 & MALE & RETIRED ENGINEER & $\mathrm{QC}$ & $\mathrm{NO}$ \\
\hline OTA099 & 76 & FEMALE & $\begin{array}{l}\text { RETIRED COMMUNITY } \\
\text { NURSE/MIDWIFE }\end{array}$ & NL & NO \\
\hline
\end{tabular}




\section{Appendix 2a: Interview questions}

For CBC Television/Télévision de Radio-Canada television-viewing households

- Please describe your CBC Television and/or Télévision de Radio-Canada viewing historically.

- How did you first learn of CBC/Radio-Canada's digital television transition?

- Describe your over-the-air access to CBC Television and/or Télévision de Radio-Canada before and after Canada's digital television transition.

- How have you adjusted your CBC Television and/or Télévision de Radio-Canada as a result of CBC/Radio-Canada's transition?

- How many times were you asked about your access to CBC/Radio-Canada television viewing before the digital transition?

- Where did you go for information related to CBC/Radio-Canada's digital television transition so that you could prepare?

- If you don't mind me asking, how much money did you spend to prepare for CBC/RadioCanada's digital television transition in the hopes that any electronics you bought would allow you to continue watching CBC Television and/or Télévision de Radio-Canada?

- Based on your own experience, how would you say your region of Canada has been served by CBC/Radio-Canada's approach to the digital television transition?

- If you were in charge of CBC/Radio-Canada's digital television transition, what would you have done differently? Are there opportunities or challenges you see as related to the transition to digital?

- Do you remember ever seeing Public Service Announcements (PSAs) on CBC Television or Télévision de Radio-Canada before the digital transition?

- How would you respond to someone who might say, "So, you've lost over-the-air access to $\mathrm{CBC} /$ Radio-Canada television. What's the big deal? Just get cable, or satellite, or watch on the Internet, or on your cell phone!'?

- Has CBC/Radio-Canada's approach to the digital television transition been a benefit to Canada? Please explain your answer.

- Has CBC/Radio-Canada's approach to the digital television transition impacted the Digital Divide in Canada? By the Digital Divide I mean barriers to accessing RadioCanada and $\mathrm{CBC}$ television in the digital age on economic, geographic or linguistic grounds. Please explain your answer. 


\section{Appendix 2b: Interview questions}

Pour les téléspectateurs de Télévision de Radio-Canada/CBC Television

- S'il vous plaît décrire votre signaux Télévision de Radio-Canada/CBC Television et / ou à la télévision de la SRC affichage historiquement.

- Comment avez-vous appris de Télévision de Radio-Canada/CBC Television transition vers la télévision numérique?

- Décrivez votre accès à Télévision de Radio-Canada/CBC Television sur la télévision de l'air avant et après la transition du Canada de la télévision numérique.

- Comment avez-vous réglé votre Télévision de Radio-Canada/CBC Television et / ou regarder de la télévision de $\mathrm{CBC}$ à la suite de $\mathrm{CBC} /$ Radio-Canada de transition?

- Combien de fois avez-vous été interrogé sur votre accès à Télévision de RadioCanada/CBC Television et / ou regarder la télévision CBC avant le passage au numérique?

- Où avez-vous des informations relatives à la transition Télévision de Radio-Canada/CBC Television de la télévision numérique afin que vous puissiez préparer?

- Si vous n'avez pas l'esprit de me demander, combien d'argent avez-vous dépensé pour se préparer à la transition Télévision de Radio-Canada/CBC Television de la télévision numérique dans l'espoir que toute l'électronique que vous avez achetés vous permettra de continuer à regarder Radio-Canada et / ou de télévision Radio-Canada?

- En se basant sur votre propre expérience, comment diriez-vous de votre région du Canada a été signifié par l'approche Télévision de Radio-Canada/CBC Television à la transition vers la télévision numérique?

- Si vous étiez en charge de la transition Télévision de Radio-Canada/CBC Television de la télévision numérique, qu'auriez-vous fait différemment? Y at-il des opportunités ou défis que vous voyez comme liés à la transition vers le numérique?

- Vous souvenez-vous avoir vu des messages d'intérêt public (MIP) à Télévision de RadioCanada/CBC Television avant le passage au numérique?

- Comment répondriez-vous à quelqu'un qui pourrait dire: "Alors, vous avez perdu overthe-air l'accès à Télévision de Radio-Canada/CBC Television. Ce n'est pas une grosse affaire! Juste obtenir le câble ou le satellite ou regarder sur Internet ou sur votre téléphone portable!'?

- Est-ce que Télévision de Radio-Canada/CBC Television approche de la transition vers la télévision numérique été un avantage pour le Canada? S'il vous plaît expliquer votre réponse.

- Est-ce que Télévision de Radio-Canada/CBC Television approche de la transition vers la télévision numérique incidence sur la fracture numérique au Canada? Par la fracture numérique que je veux dire obstacles à l'accès de Télévision de Radio-Canada/CBC Television à l'ère numérique pour des raisons économiques, géographiques ou linguistiques. S'il vous plaît expliquer votre réponse. 


\title{
Appendix 2c: Interview questions
}

\author{
Questions for CBC/Radio-Canada Management
}

- Please describe your role in CBC/Radio-Canada's digital television transition.

- Please name and describe the role of members of the $\mathrm{CBC} /$ Radio-Canada digital television transition team.

- Who else has the $\mathrm{CBC} /$ Radio-Canada transition team worked with in relation to the transition?

- Please identify the goals and objectives for the transition at the beginning of CBC/Radio-Canada's transition compared to the current goals and objectives for CBC/Radio-Canada's transition.

- What were the identified challenges and opportunities related to the transition?

- Please give a chronological run down of strategic meetings you held with regards to the transition and the resulting action items.

- What role has the Broadcasting Act played in CBC/Radio-Canada's DTV transition?

- What role has the CRTC and CRTC hearings played in CBC/Radio-Canada's DTV transition?

- What role has spectrum played in CBC/Radio-Canada's DTV transition?

- What role has government funding played in CBC/Radio-Canada's DTV transition?

- What role has Canada's rural and urban terrain played in CBC/Radio-Canada's DTV transition?

- What role have OTA CBC/Radio-Canada TV viewers played in CBC/RadioCanada's DTV transition?

- Describe the process of deciding digital television transmitter placement as it related to coverage.

- What was the initial plan and current plan in terms of serving the regions post transition?

- Please advise the costs in relation to transmitter hardware, installation and maintenance.

- Detail the decision to not upgrade remaining analogue CBC/Radio-Canada's transmitters to digital.

- How has vertical integration of Canada's broadcasting system influenced CBC/Radio-Canada's DTV transition?

- How has CBC/Radio-Canada's approach to the transition helped in bettering Canadian society? 
- How has CBC/Radio-Canada's approach to the digital television transition impacted the digital divide in Canada?

- What is CBC/Radio-Canada's transition plan in terms of roll out of MDTV broadcasting?

- What is the follow up work required in relation to the transition? 


\section{References}

Anderson, B. (1983). Imagined communities: Reflections on the origin and spread of nationalism. London: Verso.

Anthony, I. (2002, 1 October). The roots of Canadian television: How it all began and where it's headed. Broadcaster Magazine. Retrieved from http://www.broadcastermagazine.com/features/the-roots-of-canadian-television/.

Armstrong, M. \& Weeds, H. (2007). Public service broadcasting in the digital world. In P. Seabright \& J. Hagen (Eds.), The economic regulation of broadcasting markets: Evolving technology and the challenges for policy. New York: Cambridge University Press.

Armstrong, R. (2010). Broadcasting policy in Canada. Toronto: University of Toronto Press.

Aubé, P. (2013). Mobile digital television (ATSC M/H) - Field testing \& measurements. SYNC: Online technology magazine. Issue 3. Retrieved from http://www.cbc.radiocanada.ca/en/reporting-to-canadians/sync/sync-issue-3-2013/mobile-digital-television/.

BCE. (2001, January 9). Bell Globemedia Launched. Retrieved from http://www.bce.ca/news-and-media/releases/show/bell-globemedia-launched.

Baer, W.S. (2010). Future directions for US public service media. In P. Iosifidis (Ed.) Reinventing public service communication: European broadcasters and beyond, pp. 258-272. New York: Palgrave Macmillan.

Barney, D. D. (2005). Communication technology. Vancouver: UBC Press.

Baudrillard, J. (1994). Simulacra and Simulation. Ann Arbor: The University of Michigan Press.

Bélanger, P. C. (2005). Online news at Canada's national public broadcaster: An emerging 
convergence. Canadian Journal of Communication, 30(3), 411-427.

Bird, R. (1988). Documents of Canadian broadcasting. Ottawa: Carleton University Press.

Bociurkiw, M. (2011). Feeling Canadian: Television, nationalism, and affect. Waterloo, ON: Wilfred Laurier University Press.

Brevini, B. (2013). Public service broadcasting online: A comparative European policy study of PSB 2.0. New York: Palgrave Macmillan.

British Broadcasting Corporation (BBC). (n.d.). The BBC story: 1920s. Retrieved from http://downloads.bbc.co.uk/historyofthebbc/1920s.pdf.

British Broadcasting Corporation (BBC). (1999). Annex 8: Market failure in broadcasting. Retrieved from http://news.bbc.co.uk/hi/english/static/bbc_funding_review/reviewco.pdf.

Broadcaster Magazine (2012, July 17). CRTC approves CBC application to remove all analog transmitters. Retrieved from http://www.broadcastermagazine.com/news/crtcapproves-cbc-application-to-remove-all-analog-transmitters/1001548989/?\&er=NA.

CBC/Radio-Canada. (1977). 1952: CBC television debuts. Retrieved from http://www.cbc.ca/archives/entry/1952-cbc-television-debuts.

CBC/Radio-Canada. (1997). CBC annual report 1996-1997. Retrieved from http://publications.gc.ca/collections/collection_2013/radio-canada-cbc/BC1-1997-4eng.pdf.

CBC/Radio-Canada. (2000). CBC Radio 3 goes live on the internet. Retrieved from http://www.cbc.ca/archives/entry/cbc-radio-3-goes-live-on-the-internet.

CBC/Radio-Canada. (2001). CBC/Radio-Canada annual report 2000-2001. Retrieved from http://publications.gc.ca/collections/Collection/BC1-2001-5E.pdf. 
CBC/Radio-Canada. (2003). CBC/Radio-Canada annual report 2002-2003. Retrieved from http://www.cbc.radio-canada.ca/_files/cbcrc/documents/financial-reports/2002-2003ar.pdf.

CBC/Radio-Canada. (2006a). About us. Retrieved from http://web.archive.org/web/20060709002134/http://zed.cbc.ca/go?c=zedaboutus.

CBC/Radio-Canada. (2006b). Striking the right balance: CBC/Radio-Canada annual report 2005-2006. Retrieved from http://www.cbc.radiocanada.ca/_files/cbcrc/documents/financial-reports/2005-2006-ar.pdf.

CBC/Radio-Canada. (2007). Radio-Canada.ca - en bref.

CBC/Radio-Canada. (2010) Satellite television access to CBC/Radio-Canada: It's time to get it right. Retrieved from https://web.archive.org/web/20150202213713/http://www.cbc.radiocanada.ca/en/explore/strategies/satellite/.

CBC/Radio-Canada. (2012a). Shut-down of over-the-air analogue television transmission July 31,2012 . Retrieved from https://web.archive.org/web/20160711041307/http://www.cbc.radiocanada.ca/en/explore/strategies/analoguetv.

CBC/Radio-Canada. (2012b). Annual report 2011-2012. Retrieved from http://www.cbc.radio-canada.ca/site/annual-reports/2011-2012/pdf/cbc-rc-annual-report2011-2012.pdf.

CBC/Radio-Canada. (2012c). Public process number: 2012-0509-7. Replies. Notice 
of Decommissioning of CBC/Radio-Canada's Analogue Television Rebroadcasting

Transmitters - Reply argument of CBC/Radio-Canada. Retrieved from

https://services.crtc.gc.ca/pub/DocWebBroker/OpenDocument.aspx?DMID=1733163.

CBC/Radio-Canada. (2012d). Demande de modification de licence pour

l'entreprise de programmation de television numérique CBOFT-DT Ottawa afin de

changer ses paramètres techniques. Regarding 2012-1030-2. Retrieved from

https://services.crtc.gc.ca/pub/DocWebBroker/OpenDocument.aspx?AppNo=201210302

CBC/Radio-Canada. (2012e). ENGINEERING REPORT

ER12-041 MOBILE DTV (ATSC M/H) FIELD TESTING AND

MEASUREMENTS. Retrieved from http://www.cbc.radio-

canada.ca/_files/cbcrc/documents/reporting-to-canadians/sync/issue3/er12-041-

mobile-dtv-atsc-mh-field-testing-and-measurements.pdf.

CBC/Radio-Canada. (2012f). Frequently asked questions. Retrieved

from https://web.archive.org/web/20160430135700/http://www.cbc.radio-

canada.ca/en/explore/strategies/dtv/faq.

CBC/Radio-Canada. (2012g). Coverage Maps. Retrieved from

https://web.archive.org/web/20160430135118/http://www.cbc.radio-

canada.ca/en/explore/strategies/dtv/coverage-maps/.

CBC/Radio-Canada. (2012h). Transmitter and channel lists: Transmitter conversion. Retrieved from https://web.archive.org/web/20160430135706/http://www.cbc.radiocanada.ca/en/explore/strategies/dtv/transmitter-and-channel-lists.

CBC/Radio-Canada. (2012i). Shut-down of over-the-air analogue television transmission - 
July 31, 2012. Retrieved from

https://web.archive.org/web/20120630122115/http://cbc.radio-

canada.ca/en/explore/strategies/analoguetv

CBC/Radio-Canada. (2012j). Analogue Shutdown: Affected Transmitters Fin de la transmission analogique : Émetteurs touches. Retrieved from http://web.archive.org/web/20160528005401/http://cbc.radiocanada.ca/_files/cbcrc/documents/analogue-tv/analogue-transmitters-emetteursanalogiques.pdf

CBC/Radio-Canada. (2013). HOCKEY IS BACK: CANADIANS TUNE IN TO CBC'S HOCKEY NIGHT IN CANADA IN RECORD NUMBERS ON SATURDAY, JANUARY 19. Retrieved from http://web.archive.org/web/20130616201851/http://www.cbc.ca/mediacentre/hockey-isback-canadians-tune-in-to-cbcs-hockey-night-in-canada-in-record-numbers-on-saturdayjanuar.html

CBC/Radio-Canada. (2014a). GOING THE DISTANCE: Annual Report 2013-2014. Retrieved from http://www.cbc.radio-canada.ca/_files/cbcrc/documents/annualreport/2013-2014/cbc-radio-canada-annual-report-2013-2014.pdf.

CBC/Radio-Canada. (2014b). Broadcasting Notice of Consultation CRTC 2014-190 - Let's Talk TV Call for comments on a formal review of the television system. Retrieved from http://www.cbc.radiocanada.ca/_files/cbcrc/documents/submissions/policy-review.pdf.

CBC/Radio-Canada. (2014c). Est-ce possible de regarder la ICI 
Radio-Canada Télé en continu sur votre site? Retrieved from

http://servicesfrancais.radio-canada.ca/auditoire/faq/est-ce-possible-regardertelevision-rc-continu-site/.

CBC/Radio-Canada. (2015a). \#CREATINGCONNECTIONS: Annual Report 2014-2015.

Retrieved from http://www.cbc.radio-canada.ca/site/rapports-annuels/2014-2015/indexen.html.

CBC/Radio-Canada. (2015b). 2015-0443-1. CBWFT-DT

Winnipeg. Demande de modification technique à la licence de radiodiffusion

d'une entreprise de programmation de télévision numérique ou

analogique - Formulaire 302. Retrieved from

https://services.crtc.gc.ca/pub/DocWebBroker/OpenDocument.aspx?AppNo=2015-

0443-1.

CBC/Radio-Canada. (2015c). Speaking notes for Hubert T. Lacroix, President and CEO, at the annual public meeting September 29, 2015, Winnipeg. Retrieved from http://www.cbc.radio-canada.ca/en/media-centre/2015/09/29b/.

CBC/Radio-Canada. (2015d). EVERYONE, EVERY WAY

CBC/RADIO-CANADA'S FIVE-YEAR STRATEGIC PLAN. Retrieved from http://www.cbc.radio-canada.ca/_files/cbcrc/documents/strategy-2015/document2015en.pdf.

CBC/Radio-Canada, (2015e). In the green spotlight: A few stories we're especially proud of this year. Retrieved from http://www.cbc.radio-canada.ca/en/reporting-tocanadians/reports/environmental-performance-report/environmental-performance-report2014-2015/in-the-green-spotlight/ 
CBC/Radio-Canada. (2016a). News release. Update: Federal budget 2016 and

reinvestment in CBC/Radio-Canada. Retrieved from

http://www.cbc.radio-canada.ca/en/media-centre/2016/03/23/.

CBC/Radio-Canada. (2016b). Welcome to a sneak peak (sic) of an all-new way to watch your CBC-TV favourites, original digital programming, award-winning documentaries and Kids' CBC. Retrieved from http://web.archive.org/web/20170119224336/http:/watch.cbc.ca/about.html

CBC/Radio-Canada. (2017). Our history. Retrieved from https://web.archive.org/web/20160416042331/http://www.cbc.radiocanada.ca/en/explore/our-history/.

Canada. (1965). Report of the committee on broadcasting. Ottawa: Queen's Printer.

Canada. (1991). Broadcasting Act. S.C., c.11. Retrieved from http://laws-lois.justice.gc.ca/PDF/B-9.01.pdf.

Canada. (1993). Telecommunications Act. S.C., c.38. Retrieved from http://laws-lois.justice.gc.ca/PDF/T-3.4.pdf.

Canada. (1997). Broadcasting Distribution Regulations. SOR/97-555. Retrieved from http://laws.justice.gc.ca/eng/regulations/SOR-97-555/.

Canada. (2016, March 22). Growing the middle class. Retrieved from http://www.budget.gc.ca/2016/docs/plan/budget2016-en.pdf.

Canada. (2016, May 14). CRTC continuing to monitor implementation of new basic television package and pick-and-pay. News release. Retrieved from http://news.gc.ca/web/articleen.do?nid=1070799. 
Canada. (2016, June 28). Canadian content in a digital world: Expert advisory group announced. News release. Retrieved from http://news.gc.ca/web/articleen.do?nid=1091689\&tp=1.

Canada. (2016, September 7). Speech. Jean Pierre Blais at the public hearing to discuss the implementation of the new basic television package and flexible packaging options in Canada. Retrieved from http://news.gc.ca/web/article-en.do?nid=1120849.

Canada. Parliament. House of Commons. (2006, November 27). Edited Hansard Number 087. 39th Parliament, $1^{\text {st }}$ Session. Retrieved from http://www.parl.gc.ca/HousePublications/Publication.aspx?DocId=2544166.

Canada. Parliament. House of Commons. Standing Committee on Canadian Heritage. (2008, February). Report on the Standing Committee on Canadian Heritage. CBC/Radio Canada: Defining distinctiveness in the changing media landscape. Retrieved from http://www.parl.gc.ca/content/hoc/Committee/392/CHPC/Reports/RP3297009/chpcrp06/ chpcrp06-e.pdf.

Canada. Parliament. House of Commons. Standing Committee on Canadian Heritage. (2011, March 2). Evidence. Retrieved from http://www.parl.gc.ca/HousePublications/Publication.aspx?DocId=5002425\&Language= E\&Mode $=1$.

Canada. Parliament. Senate. Standing Senate Committee on Transport and Communications. (2014, February 26). TRCM Meeting no. 8. Retrieved from http://senparlvu.parl.gc.ca/XRender/en/PowerBrowser/PowerBrowserV2/20140226/1/1237?useragent=Mozilla/5.0\%20\%28Windows\%20NT\%206.1;\%20WOW64\%29\%20 
AppleWebKit/537.36\%20\%28KHTML,\%20like\%20Gecko\%29\%20Chrome/51.0.2704. 103\%20Safari/537.36.

Canada, Parliament, Senate. Standing Senate Committee on Transport and Communications. (2015, July). Time for Change: The CBC/Radio-Canada in the Twenty-first Century. Retrieved from http://www.parl.gc.ca/Content/SEN/Committee/412/trcm/rep/rep14jul15-e.pdf

Canada. Task Force on the Implementation of Digital Television. (1997b). Canadian television in the digital era: The report of the task force on the implementation of digital television. Retrieved from http://publications.gc.ca/collections/Collection/CH4-1-211997E.pdf.

Canada. Treasury Board of Canada Secretariat. (2012). Public service award of excellence 2012. Retrieved from https://web.archive.org/web/20121103223338/http://www.tbssct.gc.ca/arp/aepe12-eng.asp.

Canadian Communications Foundation. (2011). CBEFT-TV (SRC TV Network), Windsor, Société Radio-Canada. Retrieved from http://www.broadcasting-history.ca/index3.html?url=http\%3A//www.broadcastinghistory.ca/listings_and_histories/television/histories.php\%3Fid\%3D16\%26historyID\%3 D122.

Canadian Communications Foundation. (2013a). Ontario, Toronto and Vicinity. CBLT-DT (CBC Network), Toronto, Canadian Broadcasting Corp. Retrieved from http://www.broadcastinghistory.ca/index3.html?url=http\%3A//www.broadcasting- 
history.ca/listings_and_histories/television/histories.php\%3Fid\%3D1\%26historyID\%3 D1.

Canadian Communications Foundation. (2013b). CITY-DT (CITY Network), Toronto, Rogers Communications. Retrieved from http://www.broadcasting-history.ca/index3.html?url=http\%3A//www.broadcastinghistory.ca/listings_and_histories/television/histories.php\%3Fid\%3D8\%26historyID\%3D 10.

Canadian Heritage. (2016, September). Digital Content in a Digital World: Focusing the Conversation. Retrieved from http://www.canadiancontentconsultations.ca/system/documents/attachments/e328d01a aa5d8b25b5b2e769f0f3ccb59f63893e/000/004/022/original/PCH-DigiCanConConsultation_Paper.pdf

Canadian Radio-television and Telecommunications Commission (CRTC). (1997). Decision CRTC 97-482. Transfer of effective control of TQS inc., a company to be incorporated and to be controlled by Communications Quebecor inc. - Application approved. Retrieved from http://www.crtc.gc.ca/eng/archive/1997/DB97-482.htm.

Canadian Radio-television and Telecommunications Commission (CRTC). (1999). Public Notice. Retrieved from http://www.crtc.gc.ca/eng/archive/1999/pb99-84.htm Canadian Radio-television and Telecommunications Commission (CRTC). (2000a). Broadcasting Decision CRTC 2000-221. Acquisition by CanWest Global Communications Corp., through its wholly-owned subsidiary CW Shareholdings Inc., of the ownership interests held previously by WIC Western International Communications 
Ltd. in various conventional television stations and in certain other broadcasting undertakings. Retrieved from http://www.crtc.gc.ca/eng/archive/2000/DB2000221.HTM.

Canadian Radio-television and Telecommunications Commission (CRTC). (2000b). Broadcasting CRTC 2000-747. Transfer of effective control of CTV Inc. to BCE Inc. Retrieved from http://www.crtc.gc.ca/eng/archive/2000/db2000-747.htm

Canadian Radio-television and Telecommunications Commission (CRTC). (2001). Broadcasting Decision CRTC 2001-283. Transfer of effective control of Vidéotron ltée to Quebecor Média Inc. Retrieved from http://www.crtc.gc.ca/eng/archive/2001/db2001-283.htm

Canadian Radio-television and Telecommunications Commission (CRTC). (2002). Broadcasting Decision CRTC 2002-303.CBLT Toronto - New transmitters. Retrieved from http://www.crtc.gc.ca/eng/archive/2002/db2002-303.htm.

Canadian Radio-television and Telecommunications Commission (CRTC). (2007a). Broadcasting Decision CRTC 2007-165. Transfer of effective control of CHUM Limited to CTVglobemedia Inc. Retrieved from http://www.crtc.gc.ca/eng/archive/2007/db2007165.htm

Canadian Radio-television and Telecommunications Commission (CRTC). (2007b). Broadcasting Decision CRTC 2007-429. Transfer of effective control of Alliance Atlantis Broadcasting Inc.'s broadcasting companies to CanWest MediaWorks Inc. Retrieved from http://www.crtc.gc.ca/eng/archive/2007/db2007-429.htm

Canadian Radio-television and Telecommunications Commission (CRTC). (2008a). ANNEXE 1A. Mémoire complémentaire Télévision française de Radio 
-Canada Demande d'autorisation de transfert d'actifs de radiodiffusion de TQS inc. à la Société Radio-Canada concernant les stations de télévision affiliées CKSH-TV SHERBROOKE CKTM-TV TROIS-RIVIÈRES CKTV-TV SAGUENAY ET SON ÉMETTEUR CKTV-TV-1 ST-FULGENCE. Retrieved from http://www.crtc.gc.ca/public/broad/applications/2008/2008-0516-1.zip.

Canadian Radio-television and Telecommunications Commission (CRTC). (2008b). Broadcasting Decision CRTC 2008-130. Canadian Broadcasting Corporation Acquisition of assets. Retrieved from http://www.crtc.gc.ca/eng/archive/2008/db2008130.htm.

Canadian Radio-television and Telecommunications Commission (CRTC). (2009). Digital Transition Models. Retrieved from https://web.archive.org/web/20100327094608/http://www.crtc.gc.ca/eng/publications/re ports/pwc09.htm.

Canadian Radio-television and Telecommunications Commission (CRTC). (2010a). Broadcasting Regulatory Policy CRTC 2010-167. A group-based approach to the licensing of private television services. Retrieved from http://www.crtc.gc.ca/eng/archive/2010/2010-167.htm.

Canadian Radio-television and Telecommunications Commission (CRTC). (2010b). Broadcasting Decision CRTC 2010-239. Canadian Broadcasting Corporation. Retrieved from http://www.crtc.gc.ca/eng/archive/2010/2010-239.htm Canadian Radio-television and Telecommunications Commission (CRTC). (2010c). 
Broadcasting Decision CRTC 2010-782. Change in the effective control of Canwest Global Communications Corp. 's licensed broadcasting subsidiaries. Retrieved from http://www.crtc.gc.ca/eng/archive/2010/2010-782.htm.

Canadian Radio-television and Telecommunications Commission (CRTC). (2010d). Broadcasting Notice of Consultation CRTC 2010-926. Notice of hearing. Retrieved from http://www.crtc.gc.ca/eng/archive/2010/2010-926.pdf

Canadian Radio-television and Telecommunications Commission (CRTC). (2011a). Transcript, Hearing 3 February 2011. (Volume 3). Retrieved from http://www.crtc.gc.ca/eng/transcripts/2011/tb0203.html.

Canadian Radio-television and Telecommunications Commission (CRTC). (2011b). Broadcasting Decision CRTC 2011-203. CBAT-TV Fredericton/Saint John - Licence amendment. Retrieved from http://www.crtc.gc.ca/eng/archive/2011/2011-203.pdf.

Canadian Radio-television and Telecommunications Commission (CRTC). (2011c). Broadcasting Regulatory Policy CRTC 2011-295. Direct-to-home satellite distribution policy - Distribution of local conventional television stations and simultaneous substitution. Retrieved from http://www.crtc.gc.ca/eng/archive/2011/2011-295.htm

Canadian Radio-television and Telecommunications Commission (CRTC). (2011d). News release. CRTC allows CBC to continue broadcasting analog television signals in 22 markets until August 2012. Retrieved from http://www.crtc.gc.ca/eng/com100/2011/r110816.htm.

Canadian Radio-television and Telecommunications Commission (CRTC). (2011e). 
Broadcasting Decision CRTC 2011-494, Continued operation of analog television rebroadcasting transmitters in mandatory markets and associated technical changes. Retrieved from http://www.crtc.gc.ca/eng/archive/2011/2011-494.htm.

Canadian Radio-television and Telecommunications Commission (CRTC). (2012a) 2011-2012 Departmental Performance Report. Retrieved from http://www.crtc.gc.ca/eng/backgrnd/dpr2012/dpr2012.pdf.

Canadian Radio-television and Telecommunications Commission (CRTC). (2012b). Notice of Decommissioning of the Corporation's Analogue Television Rebroadcasting Transmitters. Retrieved from https://services.crtc.gc.ca/pub/DocWebBroker/OpenDocument.aspx?AppNo=2012050 97.

Canadian Radio-television and Telecommunications Commission (CRTC). (2012c). Broadcasting Decision CRTC 2012-384, Revocation of licences for the rebroadcasting stations CBIT Sydney and CBKST Saskatoon and licence amendment to remove analog transmitters for 23 English- and French-language television stations. Retrieved from http://www.crtc.gc.ca/eng/archive/2012/2012-384.pdf.

Canadian Radio-television and Telecommunications Commission (CRTC). (2013). Broadcasting Decision CRTC 2013-263 and Broadcasting Orders CRTC 2013-264 and 2013-265. Canadian Broadcasting Corporation - Licence renewals. Retrieved from http://www.crtc.gc.ca/eng/archive/2013/2013-263.htm

Canadian Radio-television and Telecommunications Commission (CRTC). (2014a). Broadcasting Notice of Consultation CRTC 2014-190. Notice of hearing. Retrieved from http://www.crtc.gc.ca/eng/archive/2014/2014-190.htm. 
Canadian Radio-television and Telecommunications Commission (CRTC). (2014b). Transcript, Hearing 12 September 2014. http://www.crtc.gc.ca/eng/transcripts/2014/tb0912.htm Canadian Radio-television and Telecommunications Commission (CRTC). (2015a, ). Broadcasting Regulatory Policy CRTC 2015-24. Over-the-air transmission of television signals and local programming. Retrieved from http://www.crtc.gc.ca/eng/archive/2015/2015-24.htm. Canadian Radio-television and Telecommunications Commission (CRTC). (2015b). Broadcasting and Telecom Decision CRTC 2015-26. Complaint against Bell Mobility Inc. and Quebecor Media Inc., Videotron Ltd. and Videotron G.P. alleging undue and unreasonable preference and disadvantage in regard to the billing practices for their mobile TV services Bell Mobile TV and illico.tv. Retrieved from http://www.crtc.gc.ca/eng/archive/2015/2015-26.htm.

Canadian Radio-television and Telecommunications Commission (CRTC). (2015c). JeanPierre Blais to the London Chamber of Commerce on Let's Talk TV and the future of television [Speech]. Retrieved from http://news.gc.ca/web/article-en.do?nid=924999.

Canadian Radio-television and Telecommunications Commission (CRTC). (2015d) Communications Monitoring Report. Retrieved from http://www.crtc.gc.ca/eng/publications/reports/PolicyMonitoring/2015/cmr.htm.

Canadian Radio-television and Telecommunications Commission (CRTC). (2016a). Broadcasting Notice of Consultation CRTC 2016-44 related documents. Retrieved from https://services.crtc.gc.ca/pub/instances-proceedings/DefaultDefaut.aspx?lang=eng\&YA=2016\&S=C\&PA=b\&PT=nc\&PST=ca\#2016-44.

Canadian Radio-television and Telecommunications Commission (CRTC). (2016b) 
Broadcasting Decision CRTC 2016-110. Shaw Communications Inc., on behalf of Shaw Media Inc. and its licensed subsidiaries. Various television services and stations - Corporate reorganization (transfer of shares). Retrieved from http://www.crtc.gc.ca/eng/archive/2016/2016-110.htm

Canadian Radio-television and Telecommunications Commission (CRTC). (2016c). Broadcasting Notice of Consultation CRTC 2016-197. Broadcasting licence renewals of terrestrial broadcasting distribution undertakings (BDUs) that will expire in 2016; implementation of certain conditions of licence and review of practices in regard to the small basic service and flexible packaging requirements for all BDU licensees. Retrieved from http://www.crtc.gc.ca/eng/archive/2016/2016-197.htm.

Canadian Radio-television and Telecommunications Commission (CRTC). (2016d). Broadcasting Decision CRTC 2016-322. CKSA-DT Lloydminster and its transmitter CKSA-TV-2 Bonnyville - Disaffiliation from the CBC English-language television network. Retrieved from http://crtc.gc.ca/eng/archive/2016/2016-322.htm.

Canadian Radio-television and Telecommunications Commission (CRTC). (2016e). Telecom Regulatory Policy CRTC 2016-496. Modern telecommunications services - The path forward for Canada's digital economy. Retrieved from http://crtc.gc.ca/eng/archive/2016/2016-496.htm.

Canadian Radio-television and Telecommunications Commission (CRTC). (2016f). Canadian local over-the-air television stations have converted to digital television. Retrieved from http://www.crtc.gc.ca/eng/television/services/stations.htm.

Charland, M. (1986). Technological nationalism. Canadian Journal of Political and Social Theory, 10: 1-2, p. 196-220. 
City of Windsor. (2012, May 25). Re: French TV. Retrieved from https://services.crtc.gc.ca/pub/DocWebBroker/OpenDocument.aspx?DMID=1722065.

Clement, A., \& Shade, L.R. (2000). The Access Rainbow: Conceptualizing Universal Access to the Information/ Communications Infrastructure. In M. Gurstein (Ed.), Community informatics: enabling communities with information and communications technologies, $\mathrm{p}$ 32-51. Hershey, PA: Idea Group Pub.

Commissioner of Official Languages. (2012, June 18). Letter. Comments on CSC/RadioCanada application to shut down all analogue English- and French-language television transmitters.

Cormack, P. and Cosgrave, J.F. (2013). Desiring Canada: CBC contests, hockey violence, and other stately pleasures. Toronto: University of Toronto Press.

DeLanda, M. (2006). A new philosophy of society: Assemblage theory and social complexity. New York: Continuum.

Digital TV Europe. (2015, November 17). WRC-15 safeguards sub-700MHz band for broadcasting in EMEA. DigitalTVEurope.net. Retrieved from http://www.digitaltveurope.net/466882/wrc-15-safeguards-sub-700mhz-band-forbroadcasting-in-emea/.

Ditchburn, J. (2011, October 5). Digital TV transition goes off without much drama, heritage officials say: Digital TV transition a dud of a cliffhanger. The Canadian Press. Retrieved from http://search.proquest.com.ezproxy.lib.ryerson.ca/docview/896672102?pqorigsite $=$ summon .

Fauteux, B. (2015). Music in range: The culture of Canadian campus radio. Waterloo, 
Ontario: Wilfrid Laurier University Press.

Federal Court of Appeal. (2016, June 20). 2016 FCA 185. Retrieved from http://decisions.fcacaf.gc.ca/fca-caf/decisions/en/145408/1/document.do.

Filion, M. (1996a). Broadcasting and cultural identity: the Canadian experience. Media, Culture \& Society. Vol. 18: 447-467. London: SAGE.

Filion, M. (1996b). Radio. In M. Dorland (Ed.), The cultural industries in Canada: Problems, policies and prospects (p. 178-202). Toronto: James Lorimer \& Co.

Foucault, M. (1972). The archaeology of knowledge. New York: Pantheon Books.

Free TV Australia. (2014). Free TV today. Retrieved from http://www.freetv.com.au/SiteMedia/w3svc751/Uploads/Documents/Free_TV_Austral ia_FREE_TV_TODAY-1.pdf.

Friends of Canadian Broadcasting (FCB). (n.d.). About us. Retrieved from http://www.friends.ca/about_us.

Gasher, M., Skinner, D. \& Lorimer, R. (2012). Mass communication in Canada. Don Mills, ON: Oxford University Press.

Gates, B. (1996, January 3). Content is king. Retrieved from http://web.archive.org/web/20010126005200/http://www.microsoft.com/billgates/colu mns/1996essay/essay960103.asp.

Given, J. (2003). Turning off the television: Broadcasting's uncertain future. Kensington, N.S.W: University of New South Wales Press.

Given, J. (2015). "Did it work? Evaluating the cost and benefits of the transition to digital TV in Australia". International Journal of Digital Television. Volume 6 Number 1 Intellect Ltd Article. English language. doi: 10.1386/jdtv.6.1.7_1. 
Govier, T. (2006). What is government For? In A.D. Irvine, J.R. Saul, \& J. Russell (Eds.), In the agora: The public face of Canadian philosophy (pp. 171-174). Toronto: University of Toronto Press.

Gulyás, A. (2013). Public service media for local communities: A case study from Britain. In A. Gulyás \& F. Hammer (Eds.) Public service media in the digital age: International perspectives, pp. 139-154. Newcastle upon Tyne, UK: Cambridge Scholars Publishing.

Hamilton, S. N. (2014). Considering critical communication studies in Canada. In L.R. Shade (Ed.), Mediascapes: New patterns in Canadian communication (4th ed.), pp. 4-24. Toronto: Nelson Education.

Harvey, D. (1989). The condition of postmodernity: An enquiry into the origins of cultural change. Cambridge, MA: B. Blackwell.

Hawkins, G. (2010). Public service media in Australia: Governing diversity. In P. Iosifidis (Ed.) Reinventing Public Service Communication: European Broadcasters and Beyond, pp. 287-297. New York: Palgrave Macmillan.

Herd, N. (2008). Australia: Concentration, competition and revaluing the public interest. In D. Ward (Ed.), Television and Public Policy: Change and Continuity in an Era of Global Liberalization, pp. 63-87. New York: Lawrence Erlbaum Associates.

Holloway, S.K. (2006). Canadian foreign policy: defining the national interest. Peterborough: Broadview Press.

Industry Canada. (2012). Study of future demand for radio spectrum in Canada 20112015. Retrieved from https://www.ic.gc.ca/eic/site/smt-gst.nsf/eng/sf10253.html. Industry Canada. (2015a). Digital Canada 150 2.0. Retrieved from 
https://www.ic.gc.ca/eic/site/028.nsf/vwapj/DC150-2.0-EN.pdf/\$FILE/DC150-2.0EN.pdf.

Industry Canada. (2015b). CPC-2-1-23 - Licensing procedure for spectrum licences for terrestrial services. Retrieved from

http://www.ic.gc.ca/eic/site/smt-gst.nsf/eng/sf01875.html.

Industry Canada. (2015c). $700 \mathrm{MHz}$ spectrum auction FAQs. Retrieved from https://www.ic.gc.ca/eic/site/ic-gc.nsf/eng/07398.html.

infoDev and the International Telecommunications Union (ITU). (2016). ICT regulation toolkit / radio spectrum management radio spectrum management: Striking a balance between market flexibility and regulation. Retrieved from http://web.archive.org/web/20160408061131/http://www.ictregulationtoolkit.org/section export/pdf/5

Innis, H. A. (2007). Empire and communications. Toronto: Dundurn Press.

Innis, H. A. (2008). The bias of communication (2nd ed.). Toronto: University of Toronto Press. Iosifidis, P. (2010). Introduction. In P. Iosifids (Ed.) Reinventing public service communication: European broadcasters and beyond, pp. 1-6. New York: Palgrave Macmillan.

Jakubowicz, K. (2010). PSB 3.0: Reinventing European PSB. In P. Iosifids (Ed.) Reinventing public service communication: European broadcasters and beyond, pp. 922. New York: Palgrave Macmillan. Jenkins, H. (2006). Convergence culture: Where old and new media collide. New York: New York University Press. 
Juneau, P., Canada. Canadian Heritage \& Mandate Review Committee. (1996). Making our voices heard: Canadian broadcasting and film for the 21st century. Montréal: Reprotech Inc.

Kovacs, B. (2015, July 24). Transmitter efficiency: A Q\&A with Rich Redmond. TVtechnology.com. Retrieved from http://www.tvtechnology.com/broadcastengineering/0029/transmitter-efficiency-a-qa-with-rich-redmond/276679.

Lacroix, H. (2015, August 6). News doesn’t wait. Blog. Retrieved from http://cbcrcblog.com/cbc/news-doesnt-wait/?lang=en.

Lacroix, H. (2016, March 23). Update: Federal budget 2016 and reinvestment in CBC/RadioCanada. Cbc.radio-canada.ca. Retrieved from http://www.cbc.radiocanada.ca/en/media-centre/2016/03/23/.

Lamy, P. (2014). Results of the work of the high level group on the future use of the UHF band (470-790 MHZ). Retrieved from http://ec.europa.eu/newsroom/dae/document.cfm?doc_id=6721.

Latour, B. (1996). Aramis, or, the love of technology. Cambridge, Mass: Harvard University Press.

Latour, B. (2005). Reassembling the social: An introduction to actor-network-theory. New York: Oxford University Press.

Leblanc, D. (2016, April 25). 'Everything's on the table'. The Globe and Mail. Retrieved from http://www.theglobeandmail.com/news/national/exclusive-canadian-heritageannounces-sweeping-canconreview/article29722581/.

Lessig, L. (2008). Remix: Making art and commerce thrive in the hybrid economy. New York: The Penguin Press. 
Livingstone, S., Lunt, P., \& Miller, L. (2007). Citizens, consumers and the citizen-consumer: Articulating the citizen interest in media and communications regulation. Discourse \& Communication, 1(1), 63-89. doi:10.1177/1750481307071985.

Longford, G. (2008). Spectrum matters: Clearing and reclaiming the spectrum commons. In Moll, M., Shade, L. R. (Eds.), For sale to the highest bidder: Telecom policy in Canada. Canadian Centre for Policy Alternatives.

MacLennan, A. (2011), 'Cultural imperialism of the north? The expansion of the CBC northern service and community radio', The Radio Journal - International Studies in Broadcast and Audio Media 9: 1, pp. 63-81, doi: 10.1386/ rajo.9.1.63_1.

MacLennan, A. and Knezevic, I. (2012, October 5). Radio broadcasting, community and culture: The official languages act, broadcasting act and the case of CBEF Windsor. Retrieved from http://www.cmg.ca/en/wp-content/uploads/2011/06/CRTC-CBC-licencerenewal2012EN.pdf.

McChesney, R.W. (1999). Graham Spry and the future of public broadcasting: The 1997 Spry memorial lecture. Canadian Journal of Communication, (24) 1. Retrieved from http://www.cjc-online.ca/index.php/journal/article/view/1081/987.

McChesney, R.W. (2013). Digital disconnect: How capitalism is turning the internet against democracy. New York: The New Press.

McLuhan, M. (1964/1994). Understanding media: The extensions of man. Cambridge, MA: MIT Press.

Manovich, L. (2002). The language of new media. Cambridge, MA: MIT Press.

Masse, B. \& Comartin, J. (2012, June 7). Letter. Retrieved from 
https://services.crtc.gc.ca/pub/DocWebBroker/OpenDocument.aspx?DMID=1730010.

Miles, M.B., Huberman, A.M, Saldana, J. (2014). Qualitative data analysis: A methods sourcebook (3rd ed.). City: SAGE Publishing.

Miller, T. (2007). Cultural citizenship: Cosmopolitism, consumerism, and television in a neoliberal age. Philadelphia: Temple University Press.

Miller, T. (2013). Before, during, and after the neoliberal moment: Media, sports, policy, citizenship. In J. Scherer \& D. Rowe (Eds.), Sport, public broadcasting, and cultural citizenship: Signal lost?, pp. 30-47. New York: Routledge.

Mosco, V. (1989). The Pay-per society: Computers \& communication in the information age. Toronto: Garamond Press.

Mosco, V. (2003). Brand new world? Globalization, cyberspace, and the politics of convergence. In M. P. McCauley (Ed). Public broadcasting and the public interest, pp. 25-40. New York: M.E. Sharpe.

Mosco, V. (2004). The digital sublime: Myth, power, and cyberspace. Cambridge, MA: MIT Press.

Mosco, V. (2009). The political economy of communication ( $2^{\text {nd }}$ ed.). Los Angeles, CA: SAGE Publications Ltd.

National Hockey League (NHL). (2013, November 26). NHL, Rogers announce landmark 12year deal. (2013, November 26). Retrieved from https://www.nhl.com/news/nhl-rogers-announce-landmark-12-year-deal/c-693152.

Negroponte, N. (1995/2001). Being Digital. New York: Alfred A. Knof.

Nolet, P.A. Jr. (2012, November 30). ENGINEERING REPORT ER12041 MOBILE DTV (ATSC M/H) FIELD TESTING AND MEASUREMENTS. 
Retrieved from http://www.cbc.radio-

canada.ca/_files/cbcrc/documents/sync/issue3/er12-041-mobile-dtv-atsc-mh-fieldtesting-and-measurements.pdf.

Nordahl, T. (2011, October 19). To multicast or not to multicast ... is that the (TV news) question? (or guess which DMA offers 100 TV Channels OTA?). Retrieved from http://usjvc.com/blog/?p=263.

Nordicity Group Ltd. (2006, June). Analysis of government support for public broadcasting and other culture in Canada. Nordicity Group Ltd. Prepared for Canadian Broadcasting Corporation/La Société Radio-Canada.

Norris, P. (2001). Digital divide: Civic engagement, information poverty, and the internet worldwide. Cambridge, UK: Cambridge University Press.

O'Brien, G. (2000, October 1). CanWest all business in ROBTv takeover bid. Broadcaster Magazine. Retrieved from http://www.broadcastermagazine.com/features/canwest-allbusiness-in-robtv-takeover-bid/

Paré, D. (2005). The digital divide: Why the 'the' is misleading. In M. Klang, \& A. Murray (Eds). Human rights in the digital age, pp. 85-97. London: GlassHouse.

Parkin, M., \& Bade, R. (2006). Microeconomics: Canada in the global environment (6th ed.). Toronto: Pearson/Addison Wesley.

Parks, L. (2013a). Earth observation and signal territories: Studying U.S. broadcast infrastructure through historical network maps, Google Earth, and fieldwork. Canadian Journal of Communication, 38 (3) pp. 285-308.

Parks, L. (2013b). Infrastructural changeover: The US digital TV transition and media 
cutures. In A. N. Valdivia \& K. Gates (Eds.), The international encyclopedia of media studies, Vol. VI: Media studies futures, pp. 1-22. Malden, MA: Blackwell Publishing Ltd.

Pearson, J. (2016, June 17). A Canadian telecom is limiting a free WiFi program for lowincome families. Motherboard.tv. Retrieved from http://motherboard.vice.com/read/canadian-telecoms-limiting-wifi-low-income-familiestoronto-public-libraries-digital-divide

Picone, I., Willaert, K., \& Donders, K. (2013). The public in public service media: The case of Villasquare. In A. Gulyás \& F. Hammer (Eds.) Public service media in the digital age: International perspectives, pp. 53-67. Newcastle upon Tyne, UK: Cambridge Scholars Publishing.

Pizzi, S. \& Jones, G.A. (2014). A broadcast engineering tutorial for non-engineers (4th ed.). New York: Focal Press.

Raboy, M. (1990). Missed opportunities: The story of Canada's broadcasting policy. Kingston, ON: McGill-Queen's University Press.

Raboy, M. (1996). Public Television. In M. Dorland (Ed.), The cultural industries in Canada: Problems, policies and prospects, pp. 178-202. Toronto: James Lorimer \& Co.

Raboy, M. (2010). Media. In M. Raboy \& J. Shtern (Eds.), Media divides: Communication rights and the right to communicate in Canada, pp. 91-119. Vancouver: UBC Press.

Rajabiun, R., \& Middleton, C. (2015). Regulation, investment and efficiency in the transition to next generation broadband networks: Evidence from the european union. Telematics and Informatics, 32(2), pp. 230-244. doi:10.1016/j.tele.2014.09.001.

Roth, L. F. (2005). Something new in the air: The story of First Peoples television broadcasting 
in Canada. Kingston, ON: McGill-Queen's University Press.

Roth, L. F. (2014). Canadian First Peoples' Mediascapes: Reframing a snapshot with three corners. In L.R. Shade (Ed.), Mediascapes: New patterns in Canadian communication ( $4^{\text {th }}$ ed.), pp. 364-389. Toronto: Nelson Education.

Rowe, D. (2011). Global media sport: Flows, forms and futures. New York: Bloomsbury Academic.

Rowland, W. (2013). Saving the CBC: Balancing profit and public service. Westmount, Quebec: Linda Leith Pub.

Saulnier, A. (2015). Losing our voice: Radio-Canada under siege. Toronto: Dundurn.

Savage, P. (2010). Identity Housekeeping in Canadian Public Service Media. In P. Iosifids (Ed.) Reinventing public service communication: European broadcasters and beyond, pp. 273-286. City: Palgrave Macmillan.

Sawyer, A. (2008, January 31). Changing channels: alternative distribution of television content. Retrieved from http://www.crtc.gc.ca/eng/media/rp080606.htm\#s15b

Shade, L. R. (2005). Aspergate: Concentration, convergence, and censorship in Canadian media. In D. Skinner, J.R. Compton, \& M. Gasher (Eds.), Converging media, diverging politics: A political economy of new media in the United States and Canada, pp. 101116. Lanham, MD: Lexington Books.

Shade, L.R. (2010). Access. In M. Raboy \& J. Shtern (Eds.), Media Divides: Communication rights and the right to communicate in Canada, pp. 120-144. Vancouver: UBC Press.

Shade, L. R. (2014). Glossary. In L.R. Shade (Ed.), Mediascapes: New patterns in Canadian communication (4th ed.), pp. 448. Toronto: Nelson Education.

Shade, L. R., \& Lithgow, M. (2014). Media ownership, public participation, and democracy in 
the Canadian mediascape. In L.R. Shade (Ed.), Mediascapes: New patterns in Canadian communication (4th ed.), pp. 448. Toronto: Nelson Education.

Skinner, D. (2005). Divided loyalties: The early development of Canada's "single" broadcasting system. Journal of Radio Studies, 12(1), pp. 136-155.

Skinner, D. (2008). Television in Canada: Continuity or change? In D. Ward (Ed.), Television and public policy: Change and continuity in an era of global liberalization, pp. 3-26. New York: Lawrence Erlbaum Associates.

Smith, A. (1998). “Chapters 1-4". In Wealth of nations: Book 1. Kathryn Sutherland (Ed). New York: Oxford University Press, pp. 11-35.

Starks, M. (2007). Switching to digital television: UK public policy and the market. Chicago: Intellect.

Starks, M. (2013). The digital television revolution: Origins to outcomes. New York: Palgrave Macmillan.

Stein, J. (2001). The cult of efficiency. Toronto: House of Anansi Press.

Sterling, C.H. (2008). United States of America: Continuity and change. In D. Ward (Ed.), Television and public policy: Change and continuity in an era of global liberalization, pp. 45-59. New York: Lawrence Erlbaum Associates.

Strangelove, M. (2015). POST-TV: Piracy, cord-cutting and the future of television. Toronto: University of Toronto Press.

Stursberg R. (2012). The tower of babble: Sins, secrets and successes inside the CBC. Toronto: Douglas \& McIntyre.

TVO. (2012, April). Over-the-air transmission information. Retrieved from 
https://web.archive.org/web/20120521233622/http://about.tvo.org/who-we-are/digitalover-air-transition.

Taras, D. (1999). Power and betrayal in the Canadian media. Peterborough, ON: Broadview Press.

Taras, D. (2015). Digital mosaic: Media, power, and identity in Canada. North York, ON: University of Toronto Press.

Taylor, G. (2009). Canadian broadcasting regulation and the digital television transition [Doctoral dissertation]. Retrieved from http://digitool.library.mcgill.ca/webclient/StreamGate?folder_id=0\&dvs=145972498937 3 554.

Taylor, G. (2013). Shut off: The Canadian digital television transition. Montreal: McGill -Queens University Press.

Taylor, G. (2016). Dismantling the public airwaves: Shifting Canadian public Broadcasting to an online service. International Communication Gazette. pp. 349-364, doi: $10.1177 / 1748048516632169$

Taylor, G. \& Middleton, C. (2011). Industry Canada Consultation on a Policy and Technical Framework for the $700 \mathrm{MHz}$ Band and Aspects Related to Commercial Mobile Spectrum. Retrieved from http://www.ryerson.ca/ cmiddlet/ourresearch/taylor_middleton_700MHz_spectrum_con sultation.pdf

Television Bureau of Canada. (2015). TVB Basics 2014-2015. Retrieved from http://www.tvb.ca/page_files/pdf/infocentre/tvbasics.pdf.

Tremblay, G. (2016). Public service media in the age of digital networks. Canadian Journal of 
Communication, 41(1), pp. 191-206. Retrieved from http://www.cjconline.ca/index.php/journal/article/view/3062/2812.

UNESCO. (2005). Public service broadcasting: A best practices sourcebook. Retrieved from http://unesdoc.unesco.org/images/0014/001415/141584e.pdf.

Vipond, M. (1994). The beginnings of public broadcasting in Canada: The CRBC, 1932-36. Canadian Journal of Communication, 19(2).

Winseck, D. (1998). Reconvergence: A political economy of telecommunications in Canada. Cresskill, NJ: Hampton Press.

Yin, R. K. (1994). Case study research: Design and methods (2nd ed.). Thousand Oaks: Sage Publications. 